\title{
Estudio sistemático y biogeográfico del género Apodanthera Arn. (Cucurbitaceae)
}

Trabajo de tesis para optar al título de Doctor en Ciencias Naturales

Alumno: Lic. Manuel Joaquín Belgrano

Directores: Dr. Fernando Omar Zuloaga \& Raúl Ernesto Pozner

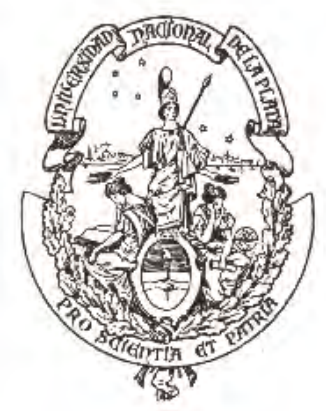

Facultad de Ciencias Naturales y Museo

Universidad Nacional de La Plata

2012 
A Nataly, Margarita, Juan Martín y Manuel que hacen de este mundo el mejor de los mundos 


\section{Agradecimientos}

Muchas fueron las personas que me brindado su ayuda durante los años que demandó este trabajo de tesis, a riesgo de olvidar mencionar a alguna de ellas, desearía agradecer muy especialmente:

A Fernando Zuloaga y Raúl Pozner, mis directores de tesis, por su enorme generosidad, permanente asistencia e infinita paciencia, por los viajes de colección compartidos, en fin, por poner a mi alcance todos los recursos necesarios y la mejor disposición para que este trabajo se llevara a cabo.

A mi familia por su apoyo incondicional, a mis padres por su dedicación y estímulo desde siempre, a mis hermanos, y en especial a Nataly, mi mujer, por haberse multiplicado por mil para cubrir mis ausencias.

Al personal del Instituto Darwinion, mi lugar de trabajo desde hace 14 años, donde he encontrado excelentes colegas y mejores amigos; a todos ellos mi más profundo agradecimiento. Por haber colaborado en temas puntuales referidos a esta tesis, quisiera mencionar en forma especial a Amalia Scataglini, por su imprescindible ayuda para llevar adelante el estudio filogenético; a Norma Deginani, por su gestión en la recepción de los especímenes en préstamo; a Francisco Rojas, Vladimiro Dudás, Martín Schinocca y Jennifer Costelo por sus maravillosas ilustraciones; a Marieta Múlgura por solventar los gastos de impresión e ilustración de esta tesis; a Amalia Suárez, por soportar el habitual desorden que provoco en la oficina que compartimos, a Rosa Guaglianone por sus cartas de recomendación en la búsqueda de subsidios, al personal de biblioteca por su siempre amable asistencia; a Osvaldo Morrone, un amigo que siempre recordaré, por compartir un viaje de colección a Bolivia en busca de Apodanthera (y de gramíneas, claro!) y que, seguramente, hubiese estado feliz de ver mi trabajo concluido.

Al personal del Departamento de Postgrado de la Facultad de Ciencias Naturales y Museo por su amable orientación durante el cursado de la carrera, en especial a la Dra. Mirta García.

A los curadores y personal de los herbarios visitados por su amabilidad y asistencia, en especial a Mirta Arriaga (BA), Gustavo Giberti (BAF), Roy Vickery (BM), Ariza Espinar (CORD), Aurelio Schinini y Antonio Krapovickas (CTES), Sara Edwards (K), Laura Iharlegui (LP), Caroline Loup (P) y Pola Figueroa (LIL), a quien recordaré especialmente. También al personal de las instituciones norteamericanas que me han enviado sus colecciones en préstamo (UC, US, F, GH, NY, TEX).

A International Association for Plant Taxonomy (IAPT) y Myndel Botanica Foundation por los subsidios otorgados para realizar viajes de colección en el norte de la Argentina y nordeste de Brasil, a la Mellon Foundation, que hizo posible las visitas a los herbarios de Londres, Kew y París.

A André Amorim (CEPEC), con quien realizamos un productivo viaje de colección por el estado de Bahia (Brasil), quien además, me brindó su hospitalidad y apoyo desinteresado.

A Brigitte Marazzi, por contribuir con obras no disponibles en nuestro pais y material de Norteamérica.

A Sofie de Smedt y Piet Stofelen (BR), Olof Ryding e Ib Friis (C), Tom Wendt (TEX, LL), Olivier Durvin

(P), Flor Retana Rentería (CIDIIR) y Edeline Gagnon (Universidad de Montreal), por el envío de imágenes de alta resolución del material depositado en sus respectivas instituciones.

A Michael Nee (NY) por su amable ayuda para estudiar el género Guraniopsis y por el envío de fotografías de los ejemplares depositados en USM.

A Susanne Renner \& Hano Schaefer (M) por sus valiosos comentarios y literatura provista. 


\section{Índice de contenidos}

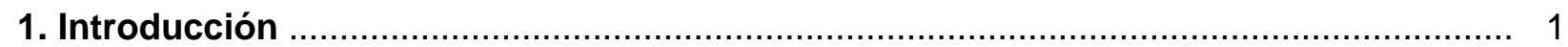

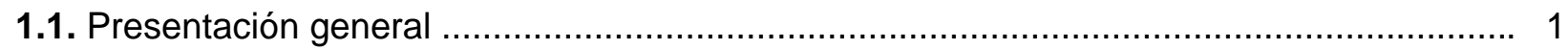

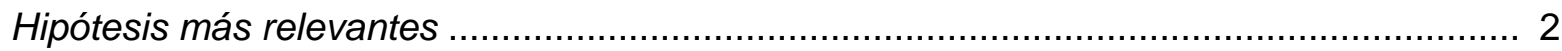

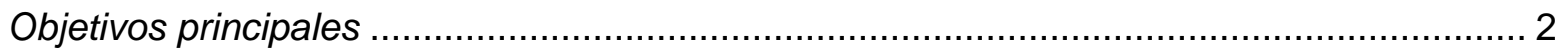

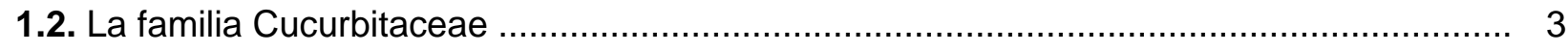

1.3. El género Apodanthera ................................................................................. 3

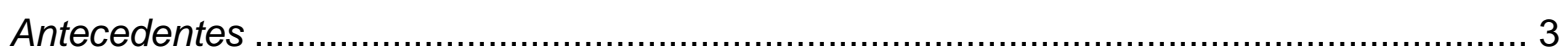

Clasificación infragenérica y distribución geográfica ..................................................... 5

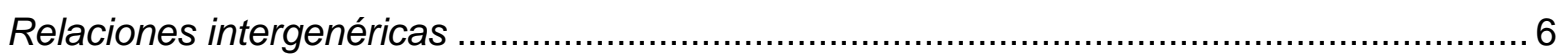

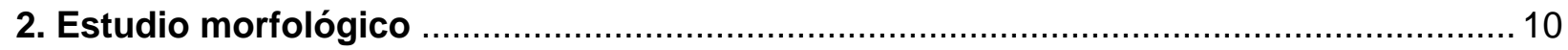

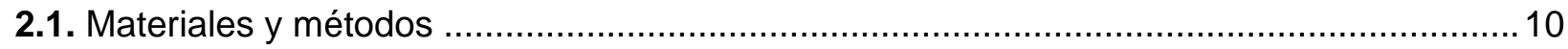

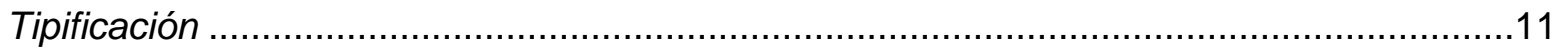

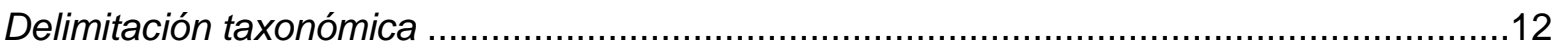

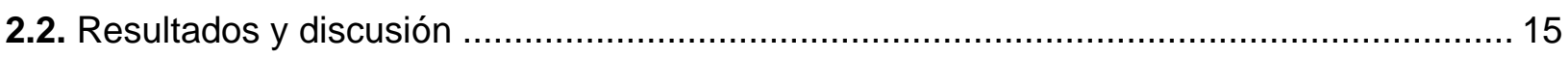

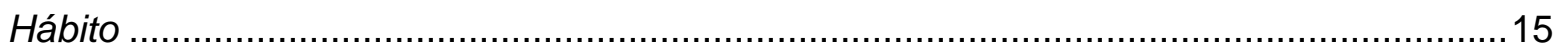

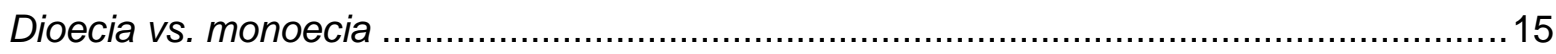

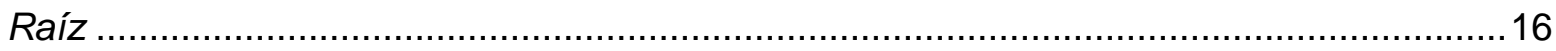

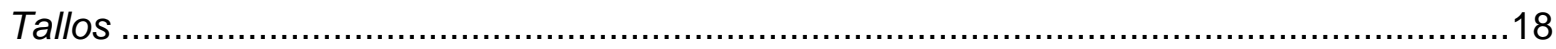

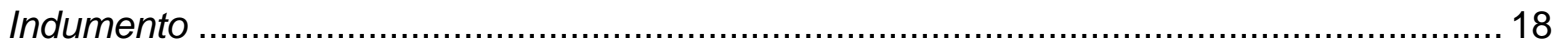

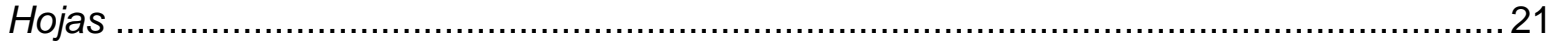

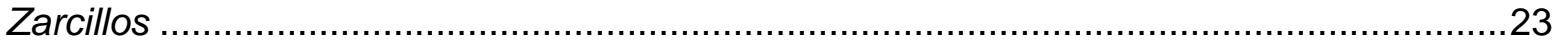

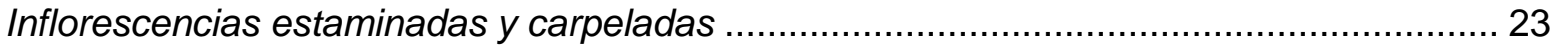

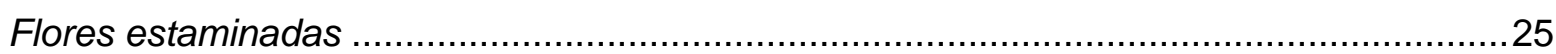

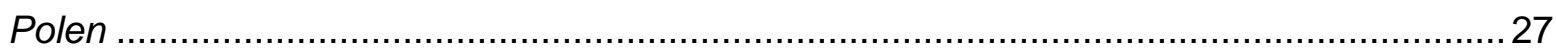

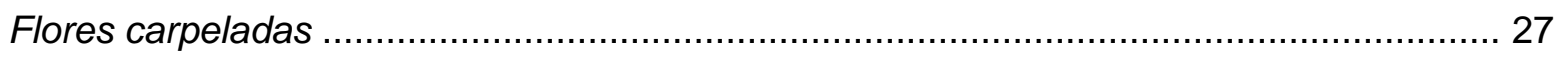

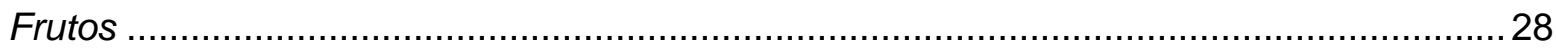

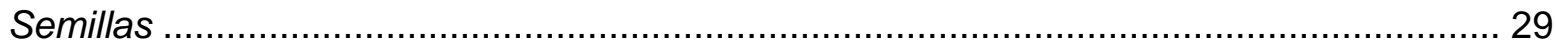

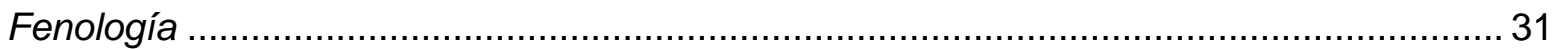

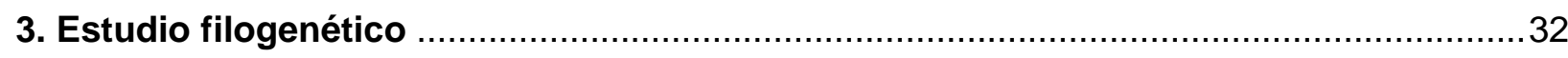

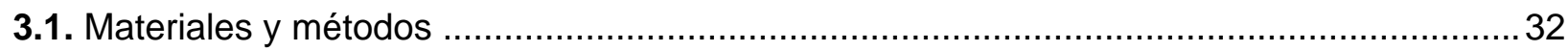

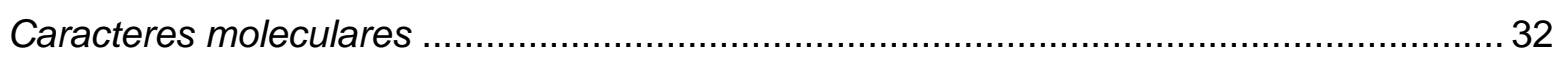

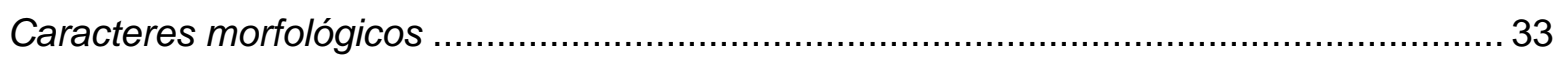

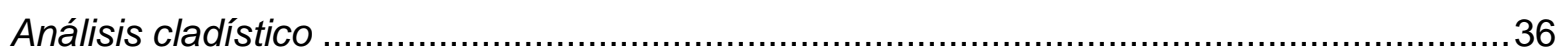

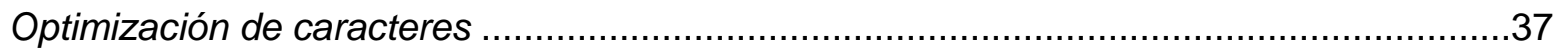




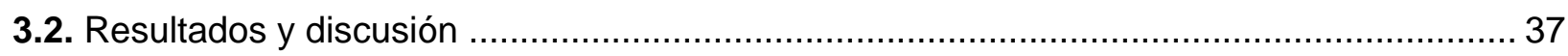

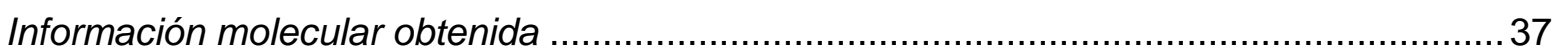

Información morfologica obtenida (matriz de caracteres morfológicos) ............................ 39

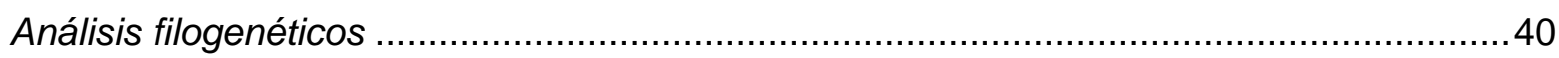

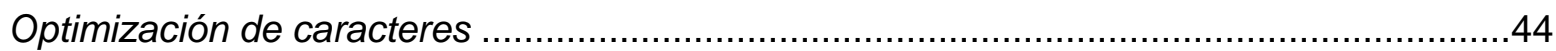

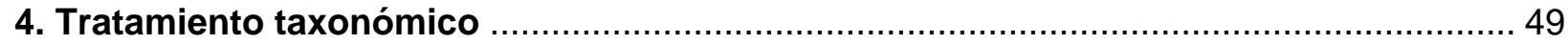

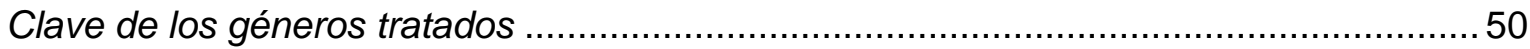

Clave de los géneros y de las especies de posición dudosa tratados ........................... 51

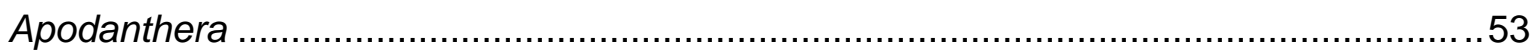

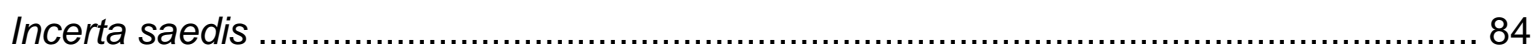

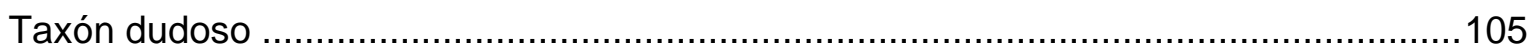

Taxones previamente excluidos de Apodanthera ...................................................... 106

Taxones excluidos de Apodanthera en esta tesis...................................................... 109

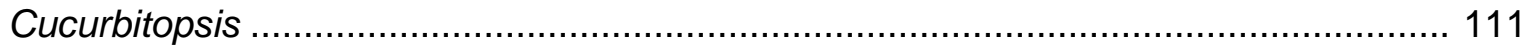

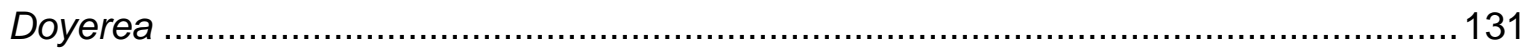

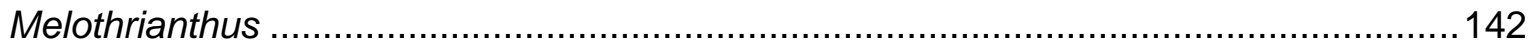

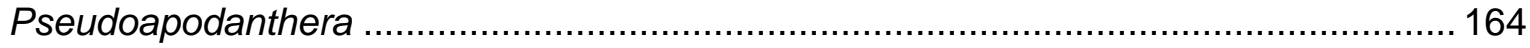

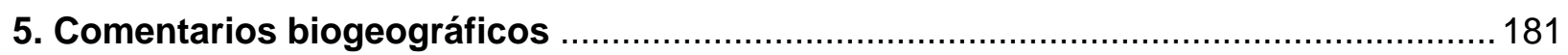

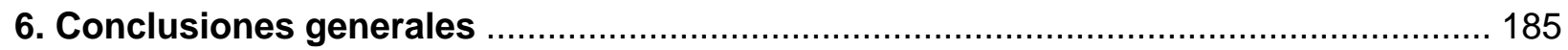

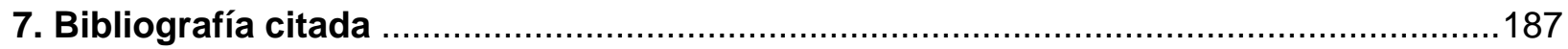

Apéndice I. Lista de taxones publicados en Apodanthera …..........................................193

Apéndice II. Índice de colecciones estudiadas ............................................................ 196

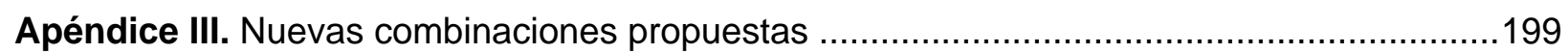

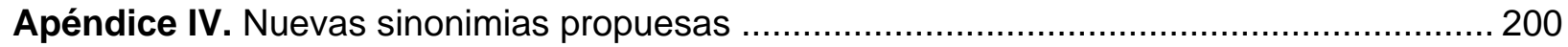




\section{Resumen}

Apodanthera es un género americano de Cucurbitaceae con distribución disyunta en áreas áridas y semiáridas de Norteamérica y Sudamérica; cuenta en la actualidad con un total 45 nombres en el nivel de especie y otros 6 en el de variedad. Hasta el presente trabajo, el tratamiento más integral del género correspondía al publicado por A. Cogniaux en 1916; en este trabajo se incluyeron las 25 especies publicadas hasta ese momento y se estructuró al género en tres secciones: Apodanthera (de los Andes de Perú y Bolivia, hasta el noroeste de la Argentina, y algunos representantes de zonas costeras de Ecuador y el este de Brasil), Pseudoapodanthera (endémica del nordeste de Brasil) y Cucurbitopsis (del sur de Estados Unidos de América y México). Numerosos autores advirtieron sobre la necesidad de realizar una revisión moderna del género, debido a la gran variabilidad interespecífica e intraespecífica observada, tanto sobre estructuras florales como foliares, y a la mencionada distribución disyunta de sus secciones.

El presente trabajo comprendió una exhaustiva recopilación bibliográfica, observación de numerosos especímenes de herbario en instituciones nacionales e internacionales (incluyendo todo el material tipo localizado), trabajo de campo, estudios morfológicos y taxonómicos. Adicionalmente, se llevó a cabo un estudio filogenético, mediante un análisis cladístico sobre la base de caracteres morfológicos y moleculares, que permitió definir grupos monofiléticos y ajustar los límites de Apodanthera frente a sus géneros afines dentro de la tribu Coniandreae. Pudo comprobarse que Apodanthera, tal como estaba circunscripto, no resultaba un género monofilético, debiendo acotarse, en sentido estricto, a sólo 7 especies de filiación andina. Las antiguas secciones de Apodanthera fueron segregadas y consideradas como géneros independientes; así, se fundaron Cucurbitopsis (con 3 especies de zonas áridas de América del Norte) y Pseudoapodanthera (con 4 especies del nordeste de Brasil). Se transfirió una especie de Apodanthera al género Doyerea y otras tres a Melothrianthus; por cuanto se amplió la circunscripción de los mismos, hasta el presente estudio considerados como monoespecíficos. Otras cinco especies sudamericanas se consideran como "incerta saedis" dentro de Apodanthera, hasta tanto puedan aclararse sus relaciones. En la presente contribución se reconocen como independientes a 23 taxones, todos en el nivel de especie, dentro de los géneros antes mencionados; se establecen 15 nuevas sinonimias, se proponen 11 nuevas combinaciones y, en relación con el trabajo nomenclatural, se realizan 23 lectotipificaciones. Para cada género y especie se brindan descripciones botánicas detalladas, mapas de distribución, ilustraciones de pluma y, en algunos casos fotografías de campo; adicionalemente, se proveen claves dicotómicas para distinguir los géneros y las especies dentro de cada uno de ellos. Finalmente, se incluyen comentarios biogeográficos y se evalua la correspondencia entre el patrón filogenético obtenido y la distribución geográfica de los géneros tratados. 


\section{Abstract}

Apodanthera is an American genus of Cucurbitaceae, with disjunct distribution areas in arid and semiarid North and South America. At present the genus includes 45 names in the specific level and other 6 as varieties. Up to this contribution, the most integral treatment of Apodanthera was published by A. Cogniaux in 1916. In this work the 25 species already described for the genus were treated, and an infrageneric schema in three sections established: Apodanthera (from the Andes of Peru and Bolivia to NW Argentina, with other few species from coastal Ecuador and E Brazil), Pseudoapodanthera (from NE Brazil), and Cucurbitopsis (from S United States and Mexico). Many authors mentioned the need of conducting a modern study of the genus, mainly due to the observed variability (inter and intraspecific) of floral and leaf structures, together with the mentioned disjunct distribution of its sections.

The present contribution involved a deep bibliographic research, observation of numerous herbarium specimens, housed at local and international institutions (including the availabe type specimens), field work, and morphologic and taxonomic studies. Additionally, a phylogenetic study was carried out, through a cladistic analysis considering both morphological and molecular characters. The monophyletic groups were defined and the limits of Apodanthera adjusted, in relation with its relative genera within the tribe Coniandreae. Apodanthera was proved as polyphyletic and must be circumscribed, «sensu stricto», to 7 Andean species. The sections of Apodanthera founded by Cogniaux were segregated and considered as independent genera: Cucurbitopsis (with 3 species from arid and semiarid areas of North America) and Pseudoapodanthera (with 4 species of NE Brazil). One species was transferred from Apodanthera to Doyerea, and other three to Melothrianthus; this way, the circumscription of these genera, considered as monotypic up to this work, was extended. Other five Southamerican species are considered as «incerta saedis» within Apodanthera, until their relationships are clarified. For the present work, 23 taxa are accepted, all of them at the species level, and as members of the genera mentioned above; 15 new synonyms are established, 11 new combinations proposed and, as part of the nomenclatural work, 23 lectotypes are designated. For every genera and species, detailed botanical descriptions are provided, together with distributional maps, line art illustrations, and, if available, pictures of plants in their habitats; additionally, keys for the involved genera and species are given. Finally, biogeographical comments are included, and the correspondence between the phylogenetic pattern and geographical distribution of the involved genera evaluated. 


\section{Introducción}

\subsection{Presentación general}

El género Apodanthera Arn. (Cucurbitaceae) cuenta en la actualidad con un total de 45 nombres en el nivel de especie y otros 6 en el varietal (Apéndice I). Se trata de un género americano, con áreas disyuntas en Norteamérica y Sudamérica. Según el esquema clasificatorio más reciente (Cogniaux, 1916), el género está estructurado en tres secciones: la sección Apodanthera, de áreas costeras de Ecuador, regiones andinas de Perú, Bolivia y el noroeste de la Argentina, con algunos representantes en el este de Brasil y centro de la Argentina; la sección Cucurbitopsis Cogn., exclusiva de Norteamérica (desde el sur de Estados Unidos de América hasta el centro-sur de México) y la sección Pseudoapodanthera Cogn., endémica del nordeste de Brasil. La mencionada obra de Cogniaux incluyó a las 25 especies descriptas y aceptadas en Apodanthera hasta ese momento. Posteriormente, se describieron nuevas entidades para Sudamérica (Jeffrey, 1992; Martínez Crovetto, 1950, 1953, 1954b, 1956a) y se propusieron algunas transferencias de taxones desde y hacia géneros afines (Jeffrey, 1992; Martínez Crovetto, 1956a; Pozner, 1996, Schaefer \& Renner, 2011a), incrementándose el número de binomios a 45. Habiendo transcurrido casi un siglo desde la obra de Cogniaux (1916) y habiéndose prácticamente duplicado el número de binomios publicados en Apodanthera, se hace evidente la necesidad de realizar un nuevo estudio de conjunto, y así lo sugieren también Jeffrey $(1978,1992)$, Pozner (1996) y Schaefer \& Renner (2011a, b).

Existen otros hechos o indicios que sugieren la necesidad de estudiar y poner a prueba la integridad del género Apodanthera, entre ellos pueden mencionarse:

- La gran variabilidad interespecífica observada en la estructura de las flores carpeladas y estaminadas, la cual no concuerda con la uniformidad de estas estructuras que usualmente muestran los demás géneros de la familia Cucurbitaceae (Martínez Crovetto, 1954a).

- La distinción y fundación de nuevas especies por parte de los autores clásicos (Cogniaux 1877, 1895, 1916, Martínez Crovetto 1953,1954b, 1956) en función de caracteres foliares, cuya variabilidad fenotípica es muy notable y responde en parte a condiciones ambientales y al fenómeno de sucesión foliar. Éste parece ser el caso de muchas de las especies de Apodanthera por lo cual resulta necesario intensificar los estudios morfológicos sobre estructuras más estables.

- La condición de monoecia y dioecia ha sido utilizada también por los autores clásicos para distinguir entre especies; sin embargo, se trata de un caracter de difícil determinación y, según lo demuestras trabajos recientes, la producción de flores 
estaminadas y/o carpeladas está determinada por condiciones ambientales y la edad de las plantas (Condon \& Gilbert, 1988; Delesalle, 1989, 1992).

- La mencionada distribución disyunta de las tres secciones del género.

- Sobre la etapa final de esta tesis se publicaron filogenias moleculares en la que Apodanthera resultó polifilético (Schaefer \& Renner 2009, 2011a).

Hipótesis más relevantes

- El género Apodanthera es polifilético y sus principales grupos de especies se correlacionan con la distribución geográfica.

- El análisis de Apodanthera en relación a los restantes géneros de la tribu Coniadreae modificará no sólo los límites genéricos de Apodanthera sino también los de sus géneros afines.

- El área geográfica comprendida por Perú, Bolivia, el centro y norte de la Argentina y sudesde de Brasil constituye el centro de diversificación de los géneros americanos de la tribu Coniandreae y por tanto se espera que las especies más conflictivas en cuanto a su asignación genérica se encuentren dentro de esa área.

\section{Objetivos principales}

- Estudiar y redefinir los límites taxonómicos de las especies del género Apodanthera y sus taxones de rango infraespecífico, y resolver los problemas de sinonimia que pudieran existir.

- Estudiar y redefinir los límites taxonómicos del género Apodanthera frente a los géneros afines dentro de la tribu Coniandreae.

- Elaborar claves dicotómicas que faciliten la identificación de los taxones aceptados.

- Ilustrar los taxones aceptados en Apodanthera, incluyendo un análisis de los principales caracteres diagnósticos.

- Analizar las relaciones filogenéticas entre los taxones aceptados.

- Analizar la distribución geográfica de los taxones aceptados.

- Comparar los patrones filogenéticos con los distribucionales y adaptaciones a los distintos hábitats.

El diseño experimental y observacional propuesto para contrastar las hipótesis antes indicadas incluye estudios morfológicos y filogenéticos, cuyos procedimientos se detallan en los Capítulos 2 y 3 , respectivamente. Las implicancias taxonómicas surgidas de estos estudios se brindan en el Capitulo 4, conjuntamente con las descripciones botánicas, ilustraciones y mapas de distribución de todos los taxones involucrados. En la discusión general de los resultados se evalúa también la biogeografía del género (Capítulo 5). 


\subsection{La familia Cucurbitaceae}

La familia Cucurbitaceae fue establecida por A. L. de Jussieu (Gen. Pl.: 393. 1789) y contiene 97 géneros y ca. 950 especies (Schaefer \& Renner 2011b), principalmente de áreas tropicales y subtropicales de ambos hemisferios; sólo unos pocos elementos alcanzan regiones templadas, por cuanto las partes aéreas de estas plantas son sensibles a las heladas.

Numerosas especies de Cucurbitaceae poseen importancia económica, usualmente como alimento, siendo muy comunes los cultivos de "pepino" (Cucumis sativus L.), "melón" (Cucumis melo L.), "sandía" [Citrullus lanatus (Thunb.) Matsum. \& Nakai] y "zapallos" y "calabazas" del género Cucurbita L. Para algunas especies se han reportado usos medicinales, principalmente como purgantes, eméticos o abortivos; otras son utilizadas como recipientes rústicos [(Lagenaria siceraria (Molina) Standl.] o como esponjas vegetales (Luffa aegyptiaca Mill.).

Las Cucurbitaceae se habrían originado en Asia durante el Cretácico tardío (Schaefer et al. 2009). Según estos autores, las especies sudamericanas serían el resultado de eventos de dispersión transoceánico desde África, los cuales involucraron principalmente linajes de las tribus Sicyoeae, parte de Coniandreae (dentro de la cual se ubica Apodanthera), Luffa y Lagenaria, entre otros. Las especies de América del Norte se habrían originado a partir de siete eventos de expansión de linajes centro y sudamericanos.

Tradicionalmente, y sobre la base de caracteres morfológicos, las Cucurbitaceae se han dividido en dos subfamilias: 1) Nhandiroboideae (antiguamente Zanonioideae), caracterizada por presentar estambres más o menos libres, estilo dividido en 2-3 estilodios, zarcillos que se enrollan por encima y debajo del punto de ramificación y granos de polen pequeños, tricolporados y estriados; 2) Cucurbitoideae, con estambres connados o fusionados de diversos modos, estilo columnar único, zarcillos que se enrollan solamente por encima del punto de ramificación y con granos de polen de tamaños y aberturas variables, con la exina nunca estriada (Jeffrey 1962, 1980, 1990). El esquema más reciente propuesto por Jeffrey (2005) reconoce estas dos subfamilias y 11 tribus, una única (Zanonieae) en Nhandiroboideae y 10 en Cucurbitoideae.

La primera filogenia de la familia basada en datos moleculares de cloroplasto (Kocyan et al. 2007), mostró correspondencia con la tradicional subdivisión en las dos subfamilias, al tiempo que reconstruyó 8 de las 11 tribus reconocidas por Jeffrey (2005), aunque prácticamente ninguna de las subtribus.

Más recientemente, Schaefer \& Renner (2011a), utilizando marcadores moleculares de cloroplasto, núcleo y mitocondria, conjuntamente con datos morfológicos tomados de bibliografía, propusieron un nuevo esquema infrafamiliar en el que sólo se reconocen 15 tribus, 
indicando que no es posible sostener a las dos subfamilias tradicionalmente aceptadas, por cuanto muchos géneros han mostrado ser polifiléticos (entre éstos Apodanthera) y prefieren, en cambio, relegar la organización infrafamilar al nivel de tribus.

\subsection{El género Apodanthera}

\section{Antecedentes}

Apodanthera fue fundado por G. A. Walker Arnott en 1841, basado en una única especie, $A$. mathewsii, proveniente de Perú. La descripición genérica es somera pero suficiente como para considerarlo válidamente publicado; adicionalmente, indicó el ejemplar tipo de la especie ( $A$. Mathews 932, de Perú).

En 1845, G. Bentham describió Apodanthera gracilis, de las islas de Taboga (Panamá) y Salango (Ecuador), admitiendo que no se encontraba muy familiarizado con la especie tipo de Apodanthera y que, tal vez, el género debía ser considerado como una sección de Melothria L. En efecto, el binomio de Bentham es considerado actualmente como un sinónimo de Melothria pendula L.

En 1853, A. Gray fundó Apodanthera undulata, de áreas desérticas del sur de los Estados Unidos de América, aunque con dudas acerca de su correcta posición genérica, y así lo indica con "?"; adicionalmente, afirma que su nueva especie es ciertamente muy distinta a las de Melothria.

En la segunda entrega de su Diagnosis de Cucurbitaceae nuevas o críticas, A. Cogniaux (1877) realizó una sinopsis de Apodanthera, reconociendo 13 especies en este género: las 3 anteriormente mencionadas, 8 nuevas especies (junto con 3 variedades) y otras 2 que fueron transferidas desde Anguria Mill. En este trabajo, Cogniaux consideró erróneamente que Apodanthera mathewsii se encontraba aún inédita (nomen tantum), y brindó una descripción más completa. Adicionalmente, describió la sección Cucurbitopsis, donde colocó a Apodanthera undulata y a otras 3 especies de América del Norte, caracterizadas por poseer hojas crasas, de borde undulado, aspérrimas, con flores grandes, las estaminadas bracteadas. En la Flora brasiliensis de Martius, Cogniaux (1878) trató a las 4 especies brasileñas descriptas hasta entonces.

En el Pródromo editado por Alfonso y Casimiro De Candolle, Cogniaux (1881) sigue un tratamiento similar al presentado por el mismo autor en 1877, citándose material adicional para algunas de las especies.

En los años subsiguientes se describieron 5 nuevas especies bajo Apodanthera (Cogniaux 1887, 1895, 1913; Watson 1889, 1890).

Posteriormente, Cogniaux (1916) publicó el tratamiento más extenso y abarcativo de Apodanthera, en el marco de la obra editada por A. Engler "Das Pflanzenreich". Aquí, ubicó al 
género en la subfamilia Cucurbiteae, tribu Melothrieae Endl., subtribu Melothriinae Müll. \& Pax, caracterizada por presentar 3 estambres, uno monotécico y los demás ditécicos, tecas rectas o apenas arqueadas, estilo con disco basal cupular o anular, frutos indehiscentes y semillas horizontales. Como novedades, Cogniaux fundó una nueva sección, Pseudoapodanthera, con 3 especies endémicas del nordeste de Brasil, fácilmente distinguibles por presentar flores estaminadas y carpeladas en densos glomérulos axilares. Adicionalmente, describió 7 nuevas especies y 2 variedades, elevándose el número de especies del género a 25 y a 5 variedades.

En el marco de la Flora de Perú, Macbride (1937) trató a las 9 especies peruanas descriptas hasta ese momento, pero sólo en forma abreviada, sin tomar decisiones taxonómicas ni resolver problemas nomenclaturales.

Luego, diversos autores continuaron incrmentando el número de binomios en Apodanthera, ya sea por descripción de nuevas entidades (Brandegee 1922, Harms 1934, Lundell 1945, Martínez Crovetto 1953, 1954b, 1956a, Jeffrey 1992) o bien por transferencia desde otros géneros (Martínez Crovetto 1954b, 1954c, 1956, Pozner 1996, Schaefer \& Renner 2011a). Algunas de ellas fueron, contrariamente, excluidas de Apodanthera (Martínez Crovetto 1956, Jeffrey 1978) o transferidas a otros (Martínez Crovetto 1956b).

Jeffrey (1992) publicó un tratamiento sobre las especies de Apodanthera del estado de Bahia, Brasil, en el que incluye 8 especies, 7 de ellas de la sección Pseudoapodanthera, y en el que describe 4 nuevas especies.

Diversos trabajos etnobotánicos, florísticos y taxonómicos involucraron a las especies de la sección Cucurbitopsis de América del Norte (Lira 2011, Lira \& Caballero 2002, Lira \& Rodríguez Arévalo 1999, 2006, Lira et al. 1998).

León (2006) en su lista comentada de las Cucurbitaceae endémicas de Perú incluye a 10 especies de Apodanthera; para cada una indica los protólogos y la distribución geográfica, sin aportar novedades taxonómicas o nomenclaturales.

Finalmente, Paiva Lima (2010) estudió la morfología polínica de diversas especies de Cucurbitaceae brasileñas, entre las que incluyó a las de Apodanthera, brindando adicionalmente, descripciones e ilustraciones.

\section{Clasificación infragenérica y distribución geográfica}

Hasta el presente, y como se mencionó anteriormente, la clasificación infragenérica reconocida para Apodanthera es la establecida por A. Cogniaux (1916), y que incluye 3 secciones: Apodanthera, Cucurbitopsis y Pseudoapodanthera, la distribución geográfica de cada una de ellas se indica en la Figura 1. La sección Apodanthera incluye especies con inflorescencias estaminadas racemiformes, hojas membranáceas, apenas escabrosas; es la más numerosa, la de mayor extensión geográfica y que involucra la mayor diversidad de hábitats; se distribuye en áreas costeras de Ecuador, en regiones andinas de Perú, Bolivia y el noroeste de la Argentina, con representantes en el sur y el este de Brasil y alcanzando en el sur de su distribución el 
norte de la Patagonia argentina. Se trata de la sección con mayores diferencias morfológicas interespecíficas. La sección Cucurbitopsis se diferencia de la sección tipo por las hojas crasas, aspérrimas; incluye 8 especies de áreas desérticas y semidesériticas de América del Norte, desde el sur de los Estados Unidos de América (estados de Nuevo México, Arizona y Texas) hasta el centro-sur de México (hasta el estado de Oaxaca). Finalmente, la sección Pseudoapodanthera, caracterizada por presentar inflorescencias en glomérulos densos o brevemente espiciformes, posee 9 especies endémicas del nordeste de Brasil, las que crecen en zonas semiáridas de la Caatinga y en los "campos rupestres".

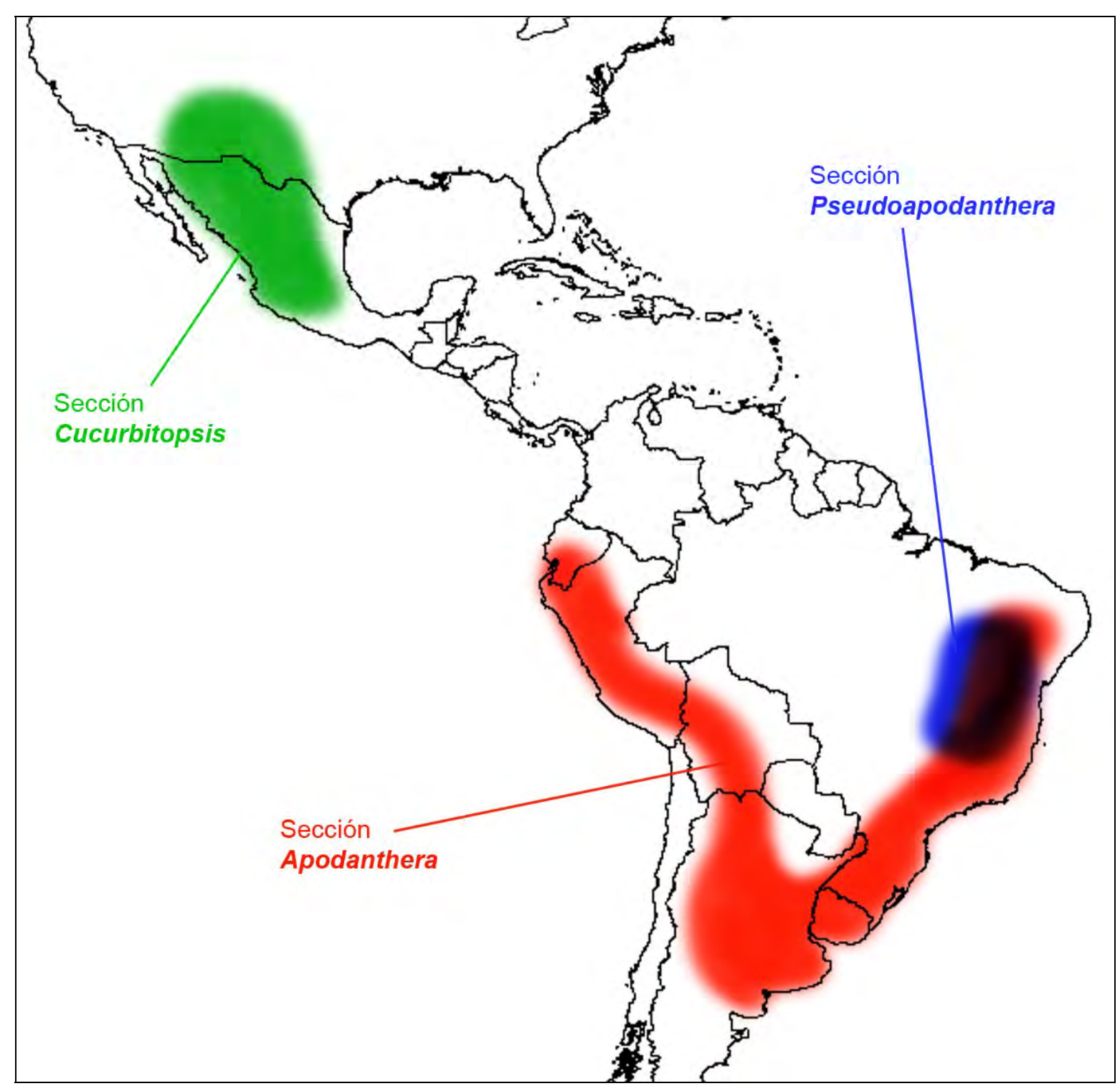

Figura 1. Distribución geográfica de las 3 secciones del género Apodanthera, según el esquema de Cogniaux (1916).

\section{Relaciones intergenéricas}

Dentro de la familia Cucurbitaceae, y según el esquema infrafamiliar más reciente (Schaefer \& Renner 2011a), Apodanthera pertenece, junto con otros 18 géneros, a la tribu Coniandreae 
Endl. Esta tribu está caracterizada por incluir enredaderas o lianas perennes; hojas simples ó 3-5-folioladas, de contorno diverso, enteras a 3-5(-9) palmati-lobadas o sectadas; zarcillos simples o compuestos; flores de tamaño y coloración variable; 2, 3 ó 5 estambres, con tecas rectas, curvadas, triplicadas o convolutas, glabras o pilosas; polen 3 colporado, a veces en tétradas; frutos carnosos indehiscentes y semillas sin alas.

A continuación, en la Figura 2 se reproduce la filogenia del orden Cucurbitales, en la que se observa el esquema infrafamiliar propuesto por Schaefer \& Renner (2011a); la tribu Coniandreae es grupo hermano del clado Benincaceae-Cucurbiteae.

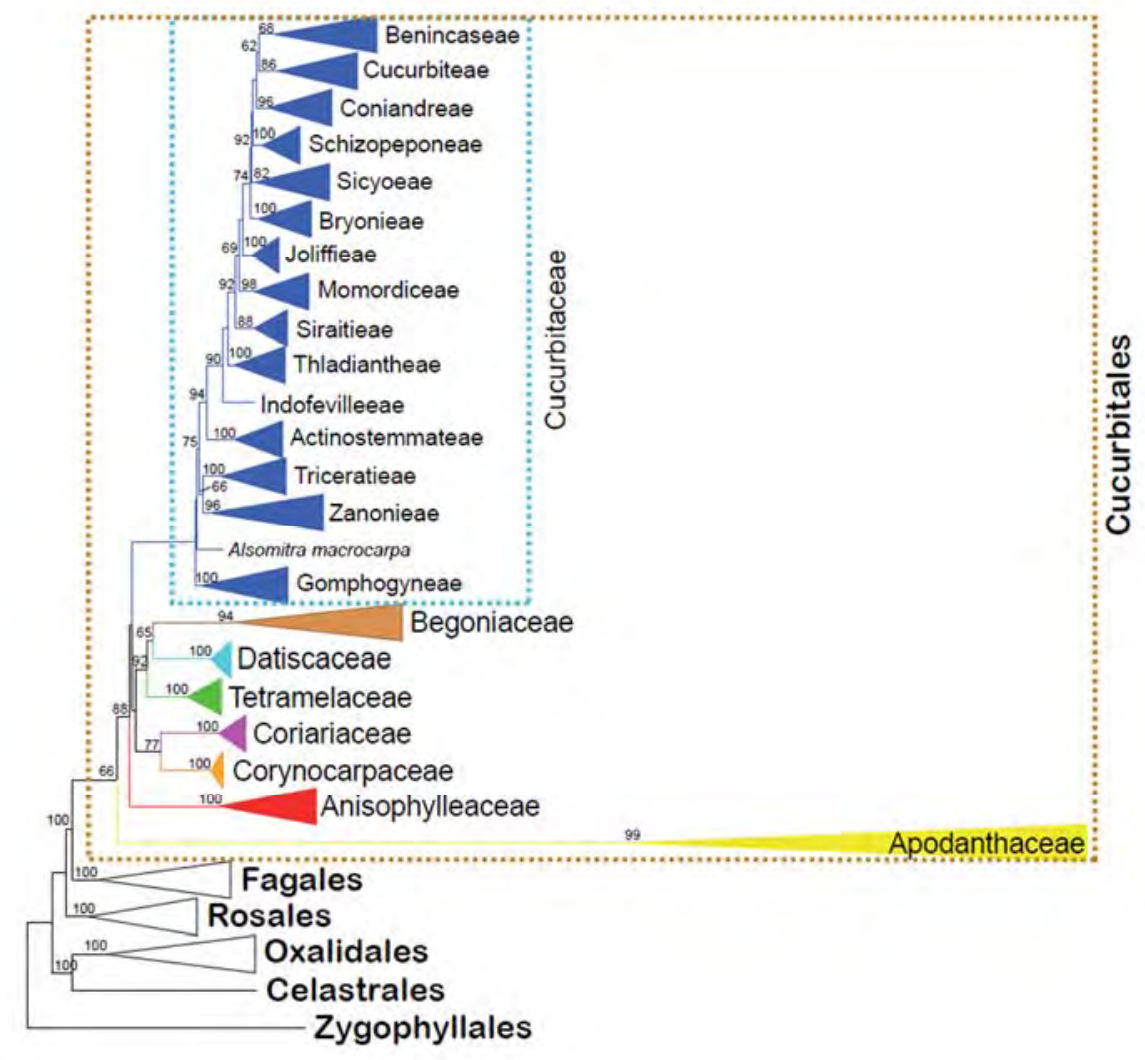

Figura 2. Filogenia del orden Cucurbitales (de Schaefer \& Renner 2011a).

Adicionalmente, en la Figura 3 se reproduce la filogenia publicada por Schaefer \& Renner (2009) para la tribu Coniandreae. En esta filogenia se incluyeron dos especies de Apodanthera: A. mandonii y $A$. sagittifolia, resultando el género polifilético. En esta reconstrucción Apodanthera mandonii se agrupa con el género monotípico Guraniopsis Cogn., mientras que $A$. sagittifolia se ubica en posición basal respecto a un clado heterogéneo que incluye diversos géneros americanos: Gurania (Schltdl.) Cogn., Psiguria Neck. ex Arn., Helmontia Cogn., Wilbrandia Silva Manso y el género monotípico Doyerea Grosourdy. 


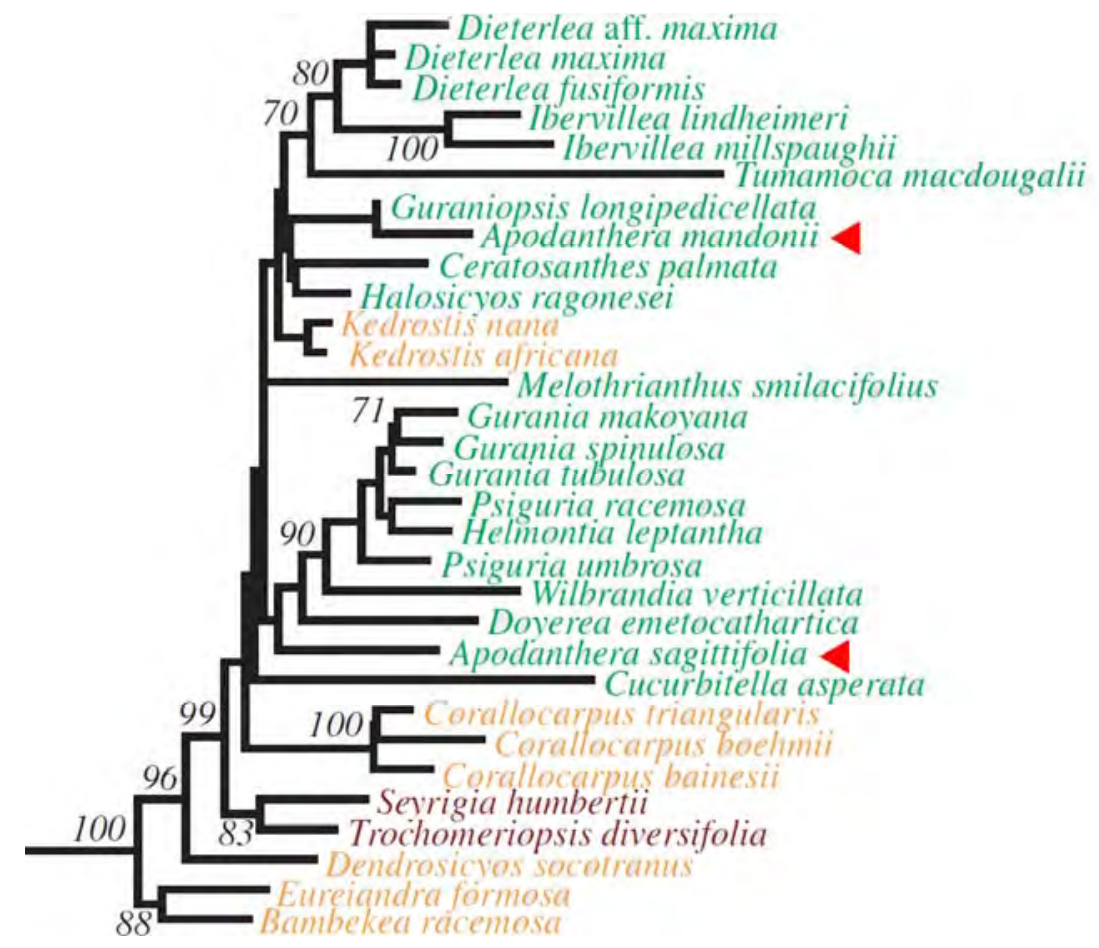

Figura 3. Filogenia de la tribu Coniandreae (de Schaefer \& Renner 2009), las flechas 4 resaltan la posición de las especies de Apodanthera incluidas en el análisis.

Sobre la base de la morfología, diversos autores han señalado a sus géneros más afines. Martínez Crovetto (1960) sostiene que se encuentra emparentado con Wilbrandia Silva Manso, del cual se separa únicamente por la estructura de la inflorescencia estaminada, racemiforme en Apodanthera y espiciforme en Wilbrandia.

Pozner (1998a) menciona la estrecha relación de Apodanthera y Cucurbitella Walp., por cuanto ambos géneros presentan 5 estigmas bífidos, 5 estaminodios y tricomas conectivales ampuliformes (sólo en algunas de las especies de Apodanthera). Cucurbitella se distingue de las secciones Apodanthera y Cucurbitopsis por sus monocasios masculinos cortamente pedunculados y de la sección Pseudoapodanthera por sus flores carpeladas solitarias.

Jeffrey (1978) señala la afinidad entre Apodanthera y Guraniopsis Cogn. (1908), un género monotípico de distribución geográfica similar en Perú, en virtud de sus zarcillos compuestos y diversos caracteres florales; según la descripción original, Guraniopsis se aparta de Apodanthera por la presencia de 2 estambres ditécicos (vs. 2 ditécicos +1 monotécico en Apodanthera). En la reconstrucción filogenética de Kocyan et al. (2007), basada en información molecular, Apodanthera mandonii Cogn. resultó grupo hermano de Guraniopsis; Schaefer \& Renner (2011a), basados en esta evidencia molecular, redujeron a Guraniopsis a la sinonimia de Apodanthera.

En numerosas publicaciones se ha mencionado la afinidad morfológica de Apodanthera con Melothria L., como se evidencia en los esquemas clasificatorios propuestos en obras clásicas 
(Arnott 1841, Cogniaux 1881, 1916) u otros más recientes (Jeffrey 1962, 1990), en donde ambos géneros están ubicados en la misma tribu (Melothrieae Endl.); consecuentemente, diversos taxones han sido tratados en uno u otro género (Martínez Crovetto 1954b, 1956, Jeffrey 1972, 1992, Pozner 1996). Algunas de las especies de Apodanthera comparten con Melothria la estructura de la inflorescencia estaminada (racemiforme) y carpelada (1-flora), la forma cupuliforme del hipanto, en número de carpelos (2), entre otros caracteres; la presencia de tricomas pestañosos rodeando a las tecas, característicos en la mayoría de las epecies de Melothria, no se observan en Apodanthera.

El género monotípico Melothrianthus Mart.Crov. se fundó a partir de la escisión de Apodanthera smilacifolia Cogn. y es afín a Apodanthera, Wilbrandia y Melothria (Martínez Crovetto 1954c); según este autor, Melotrhianthus difiere de los dos primeros por la forma del hipanto de la flor estaminada (cortamente campanulado en Melothriantus vs. subcilíndrico), las anteras basifijas (vs. dorsifijas) y, principalmente, por la presencia de un único estigma 2-lobulado (vs. 2-3 estigmas); de Melothria se distingue por los pedúnculos y pedicelos (rígidos y gruesos en Melothrianthus vs. gráciles en Melothria), las flores mayores, las estaminadas provistas de una bráctea escariosa (vs. flores pequeñas, ebracteadas) y las láminas foliares de consistencia cartácea (vs. membranácea).

En los esquemas clasificatorios más recientes, Cucurbitella, Melothrianthus y Wilbrandia están ubicados en la tribu Coniandreae, mientras que Melothria lo está en Benincaseae Ser. (Jeffrey 2005, Schaefer \& Renner 2011a). 


\section{Estudio morfológico}

\subsection{Materiales y Métodos}

Se visitaron las siguientes instituciones, con el objeto de estudiar las colecciones allí depositadas: BA, BAB, BAF, BM, CEPEC, CORD, CTES, K, LIL, LP, P. Adicionalmente, se accedió a material en préstamo proveniente de los herbarios F, GH, LL, NY, TEX, UC, US y a imágenes digitales de alta resolución de BR, CIDIIR, G, USM, W. Las abreviaturas de las instituciones antes mencionadas son las propuestas en el Index Herbariorum (Thiers 2012).

El número de especímenes (hojas de herbario) estudiados es de 670; la lista completa se provee en el índice de colecciones (Apéndice II).

Para una adecuada observación de las estructuras florales en muestras de herbario, fue necesaria su recuperación. En el caso de flores pequeñas se hidrató con agua hirviendo y detergente durante unos minutos; en el caso de flores mayores y frutos voluminosos se procedió según el protocolo de Venning (1953), tratando a las muestras con solución de $\mathrm{NH}_{4} \mathrm{OH}$ (1:19) durante aproximadamente 12 horas en estufa a $60^{\circ} \mathrm{C}$ y lavando posteriormente hasta eliminar el amonio. Luego de la restauración (por cualquiera de los dos métodos antes indicados) las muestras se conservaron transitoriamente en una solución de partes iguales de agua y glicerina y en forma más permanente en el fijador no tóxico GALA (Ácido láctico $3 \mathrm{ml}$, Ácido acético $1 \mathrm{ml}$, Alcohol absoluto $60 \mathrm{ml}$, Glicerol $5 \mathrm{ml}$, Agua $31 \mathrm{ml}$ ).

Para la observación de las muestras se utilizó una lupa binocular Nikon SMZ800. Las ilustraciones y análisis de las estructuras reproductivas se realizaron utilizando tubo de dibujo y siguiendo las recomendaciones de Holmgren \& Angell (1986).

Se realizaron 4 viajes de colección, con el objeto de observar las poblaciones en el campo, de algunas especies, y obtener muestras frescas de material para estudios morfológicos y moleculares. Estos viajes abarcaron el estado de Bahia, Brasil (noviembre de 2003), el centro y noroeste de la Argentina (enero y marzo de 2004, respectivamente), el departamento de La Paz, Bolivia (marzo de 2004). Estos viajes se financiaron a través de subsidios otorgados por la International Association of Plant Taxonomist (IAPT) y la Myndel Botanica Foundation. Durante estos viajes se tomaron muestras de herbario, depositadas en el herbario del instituto Darwinion (SI), junto con notas y fotografías de las plantas y el ambiente en el que crecen. Adicionalmente, se prepararon muestras frescas de estructuras reproductivas, conservándolas en FPA (Formaldehido-Alcohol-Propiónico) para estudios morfológicos, y se tomaron porciones foliares, se las deshidrató y conservó en sílica gel, para realizar estudios moleculares. 
Las fuentes bibliográficas más importantes sobre Apodanthera, que consideran la totalidad del género o algunas de sus secciones en conjunto, están compuestas por los trabajos de Cogniaux (1877, 1881, 1916), Jeffrey $(1978,1992)$, Lira S. \& Rodríguez A. (1999), Paiva Lima (2010). Adicionalmente, se tuvo acceso a apuntes e ilustraciones inéditos sobre el género realizados por Raúl Martínez Crovetto, junto con fragmentos de material tipo de diversas especies, depositados en el herbario del IBONE (CTES), por gentileza del Ing. A. Krapovickas (Figura 4).

La terminología morfológica se verificó y ajustó siguiendo a Font Quer (1953) y Stearn (1973).

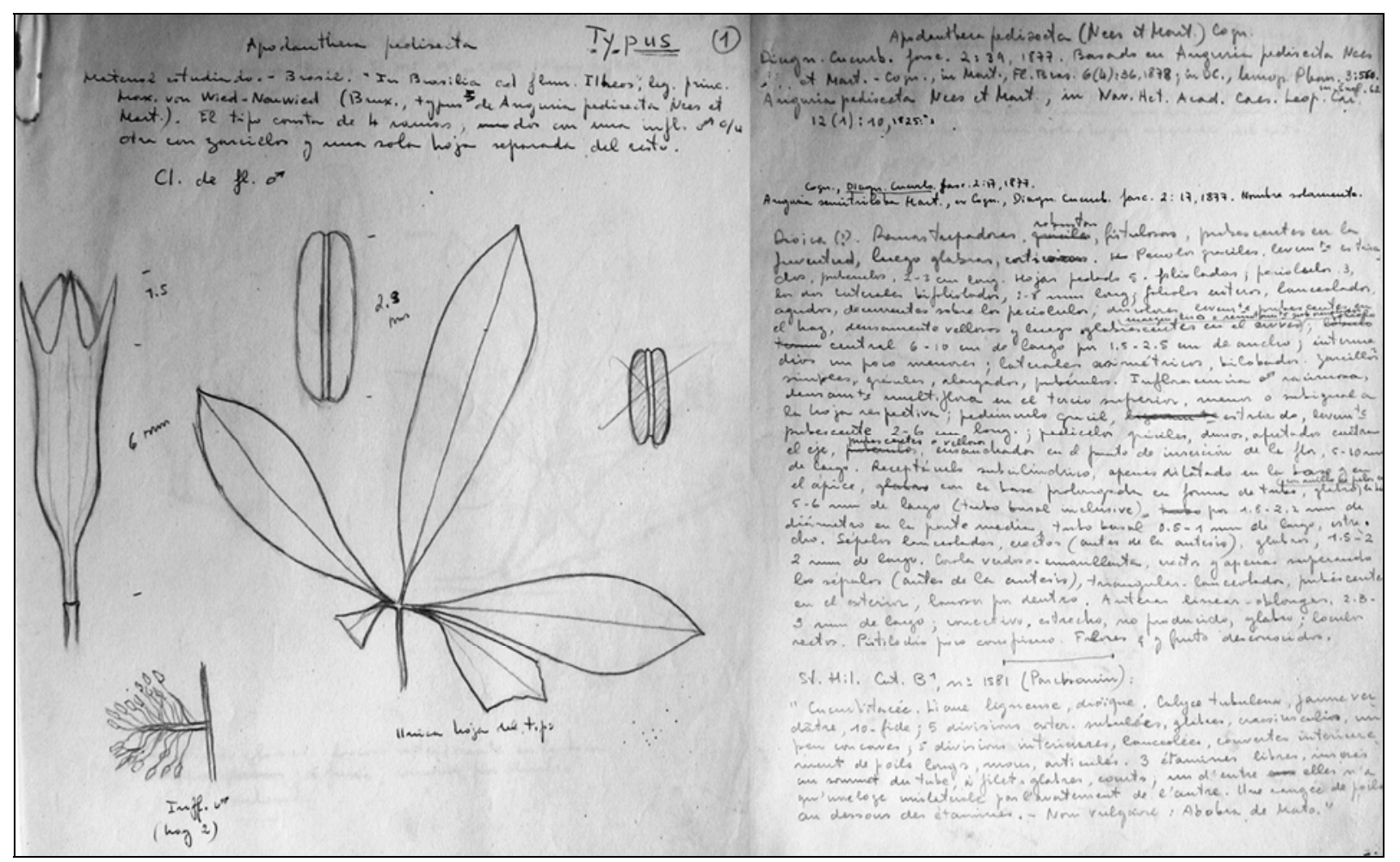

Figura 4. Notas inéditas de R. Martínez Crovetto en el herbario CTES. Apodanthera pedisecta, análisis del tipo en $\mathrm{BR}$, ilustraciones, descripción.

\section{Tipificación}

Los ejemplares tipo de cada taxón fueron precisados a partir de los protólogos correspondientes y de otras fuentes bibliográficas complementarias. En todos los casos, se siguió la indicación del tipo provista por el autor en el protólogo. En el caso de no estar explícitamente indicado el herbario de depósito del tipo, como ocurre usualmente en descripciones antiguas, se consideró como "holotipo" al ejemplar depositado en la institución en donde trabajó el autor (cfr. Stafleu \& Cowan 1976-1988; Stafleu \& Mennega 1992-1997), y atendiendo a la recomendación 9A.4 del Código Internacional de Nomenclatura Botánica (MacNeill et al. 2006), en adelante CINB. En numerosas oportunidades fue necesario desigar 
un "lectotipo", ya sea por pérdida o destrucción del tipo nomenclatural o porque el autor citó más de un ejemplar en el protólogo ("sintipos"), según lo estipulado en el CINB (Art. 9). Para ejemplificar el primero de los casos se menciona el caso de los tipos de la familia Cucurbitaceae depositados en el herbario de Berlín (B), los cuales fueron destruidos durante la Segunda Guerra Mundial, según comunicación personal del Dr. Christoph Oberprier, curador de la sección de fanerógamas de dicha institución. En la designación de lectotipos se dio prioridad y se escogió entre los isotipos disponibles, como indica el CINB. En este punto, cabe aclarar que tanto las novedades nomenclaturales como la designación de lectotipos presentadas en este trabajo de tesis no son consideradas por el CINB como efectiva y válidamente publicadas. Con este fin se están preparando los manuscritos correspondientes para su publicación en revistas científicas.

Para la localización del material original se consultó a los curadores de los principales herbarios de Europa y América del Norte y también de instituciones locales (Figuras 5 y 6). En la mayoría de los casos, se solicitó este material en préstamo; cuando no fue posible, se accedió a imágenes digitales de alta resolución provistas por muchas de estas instituciones o través de la página web de JSTOR (http://plants.jstor.org/), en donde los principales herbarios del mundo están compartiendo sus ejemplares tipo, y que cuenta con herramientas que permiten hacer magnificaciones, tomar medidas y corroborar datos de etiqueta. Adicionalmente, se consultaron las fotografías de la colección MacBride, del Field Museum of Natural History de Chicago, de la cual el instituto Darwinion cuenta con un juego completo (Figura 5C).

\section{Delimitación taxonómica}

A partir del estudio del material original se establecieron los límites de los diversos taxones involucrados y se propusieron sinonimias taxonómicas. En todos los casos se consideró la prioridad nomenclatural según lo estipula el CINB.

Paralelamente al estudio nomenclatural, se analizó exhaustivamente todo el material de herbario disponible referido a estos taxones, con el objeto de ahondar en el conocimiento de su morfología. La identificación de este material se realizó por comparación con el material original. Este estudio morfológico contribuyó a una mejor delimitación de los taxones y facilitó el establecimiento de las sinonimias taxonómicas. 


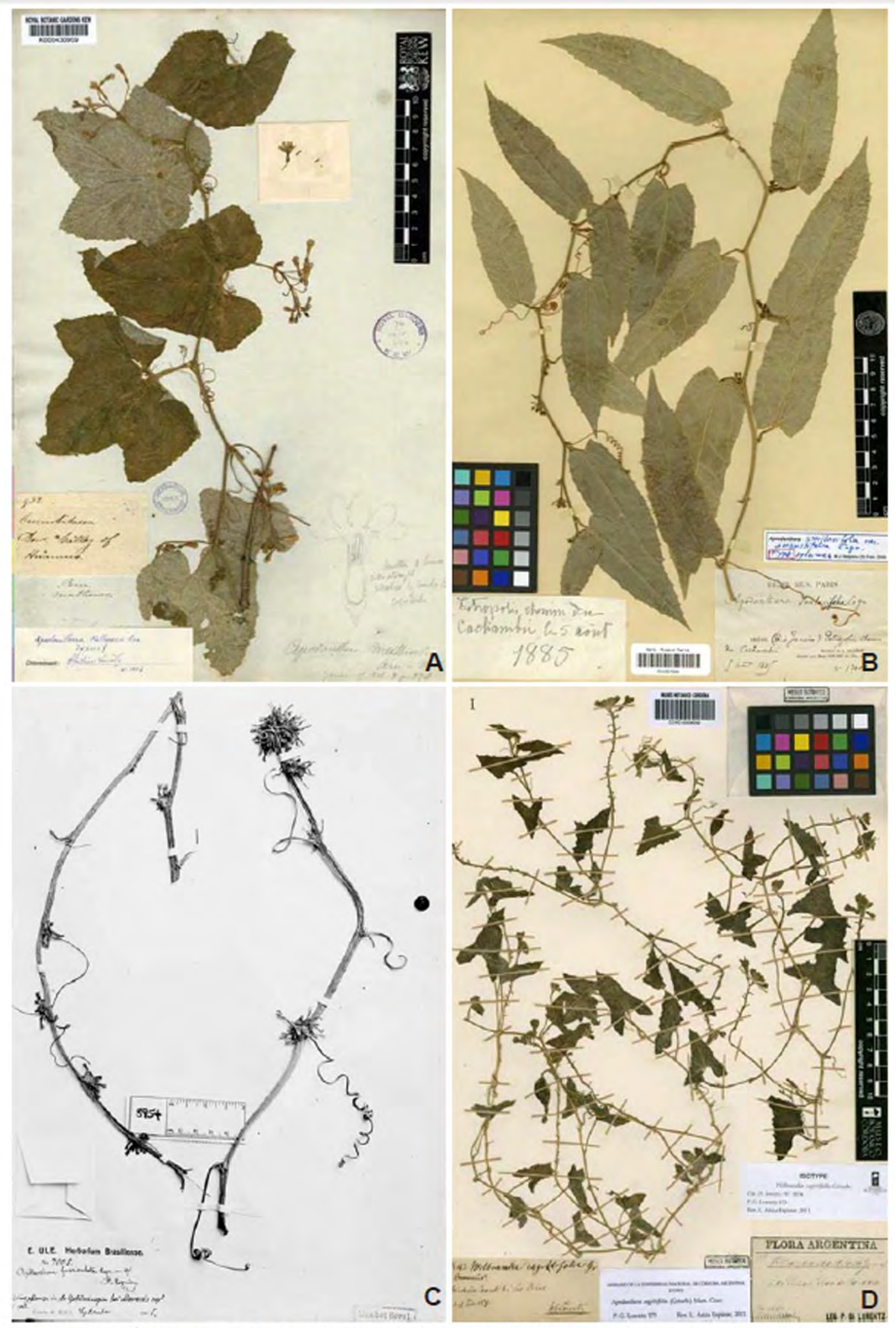

Figura 5. Especimenes tipo. A. Apodanthera mathewsii, Mathews 932 (K). B. Apodanthera smilacifolia var. angustifolia, Glaziou 17009 (P). C. Apodanthera fasciculata, Ule 7005 (B十), foto F 8954. D. Wilbrandia sagittifolia, Lorentz 173 (CORD). 


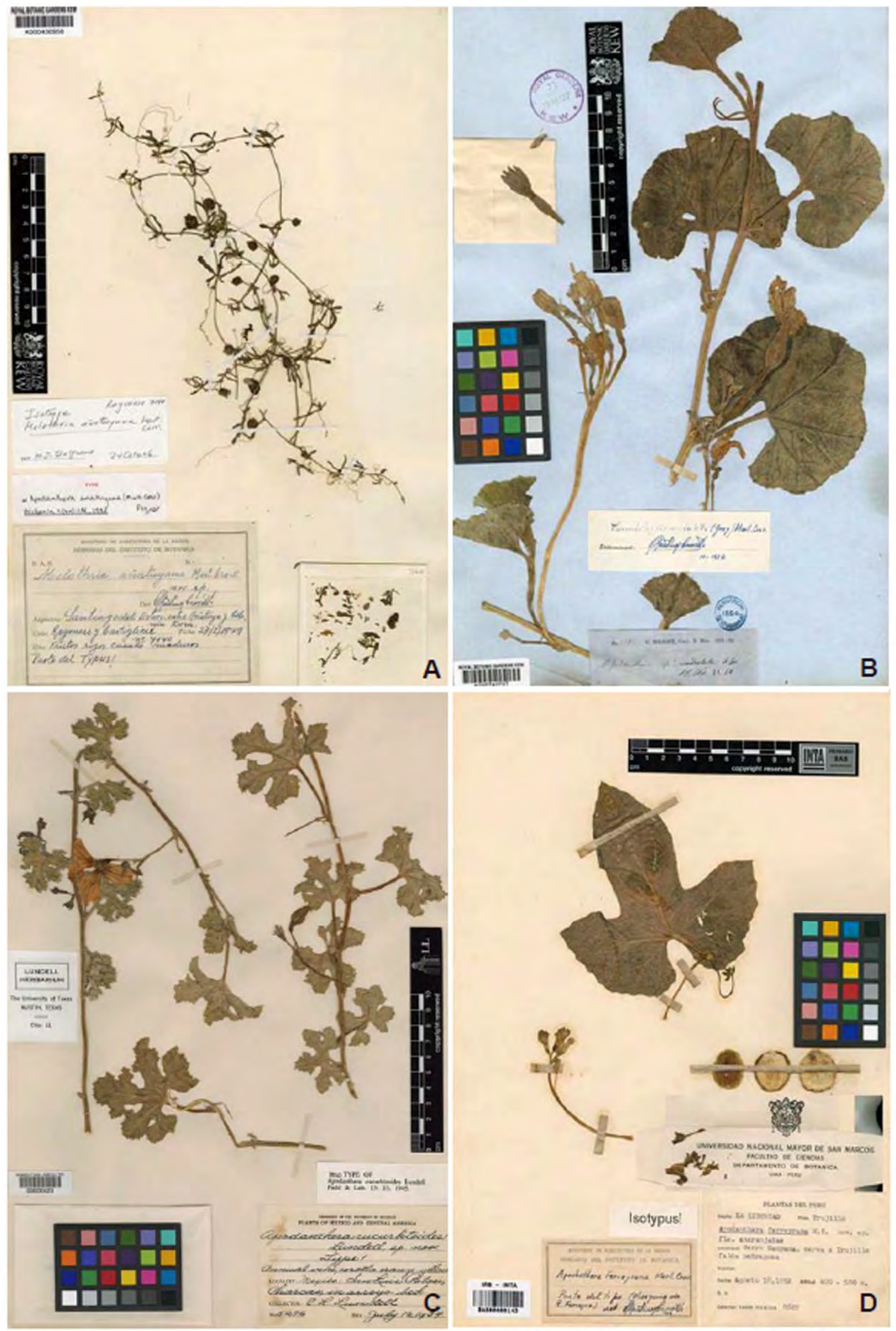

Figura 6. Especimenes tipo. A. Apodanthera anatuyana, Ragonese 7140 (K). B. Apodanthera undulata, Wright 1382 (K). C. Apodanthera cucurbitoides, Lundell 5296 (LL). D. Apodanthera ferreyrana, Ferreyra 8628 (BAB). 


\subsection{Resultados y discusión}

Hábito

Las especies de Apodanthera son hierbas perennes o subarbustos (como A. trifoliata, por ejemplo), zarcillosos, rastreros o trepadores, con raíces tuberosas reservantes y tallos anuales que pueden extenderse varios metros sobre el suelo o bien sobre la vegetación circundante (Figura 7). Según la clasificación de biotipos de Raunkiaer (1934) se las puede considerar como hemicriptófitas o caméfitas sufruticosas. Por tratarse de especies zarcillosas, todas ellas tienen capacidad para trepar por sobre otras plantas cercanas, alambrados, etc. En última instancia, el que las plantas se presenten más comúnmente como rastreras o trepadoras está relacionado con el ambiente en el que habitan. Así, aquellas especies típicas de áreas desérticas o semidesérticas, como el desierto de Sonora en América del Norte o ambientes costeros del Perú, con escasa vegetación herbácea y arbustiva y gran proporción de suelo desnudo, suelen ser rastreras (como Apodanthera undulata o A. biflora, por ejemplo). Contrariamente, aquellas de ambientes más húmedos, con gran desarrollo de vegetación en diversos estratos, como las selvas o bosques montanos húmedos del sur de Brasil, suelen ser trepadoras, alcanzando varios metros de altura por sobre la vegetación leñosa (como Apodanthera argentea o A. laciniosa).

\section{Dioecia vs. monoecia}

Muchas especies de Apodanthera han sido originalmente descriptas como dioicas, y la condición de dioecia o monoecia ha sido utilizada para distinguir a muchas de ellas entre sí (Cogniaux 1878, 1916). Sin embargo, diversos estudios sobre poblaciones naturales o bien la simple observación de un mayor número de muestras de herbario, han permitido verificar que muchas de ellas son en realidad monoicas; probablemente todas las especies pasen por fases dioicas o monoicas a lo largo de sus vidas (Roy \& Saran 1990). En efecto, estudios realizados en poblaciones de Apodanthera undulata han demostrado que un individuo puede permanecer en una misma fase unisexual durante varios años o bien alternar de una a otra año trás año (Delesalle 1987, 1989, 1992). Durante una misma estación, las plantas pueden estar en una fase estaminada o bien en una fase monoica, dependiendo de diversos factores, principalmente la edad de la planta y los nutrientes disponibles para su desarrollo (Delesalle 1992). Las plantas pequeñas, con entrenudos cortos, lo cual suele revelar deficiencias nutricionales, desarrollan casi exclusivamente flores estaminadas. Otros estudios similares realizados durante largos períodos de tiempo en enredaderas y lianas de los géneros Psiguria y Gurania, también de la tribu Coniandreae, han revelado que la expresión sexual está relacionada con el tamaño de las plantas y con las condiciones ambientales o estacionales (Condon \& Gilbert 1988). Plantas jóvenes, pequeñas, usualmente producen sólo flores estaminadas, mientras que las plantas mayores las producen carpeladas. En cualquier caso, la 
producción de flores carpeladas es mucho menos frecuente que la de flores estaminadas, y esta situación también puede verificarse en los especímenes de herbario estudiados: aproximadamente un $43 \%$ de los especímenes estudiados sólo tiene flores estaminadas, un $25 \%$ tiene flores carpeladas y/o frutos y un $32 \%$ tiene tanto flores estaminadas como carpeladas y/o frutos (en este último caso es más frecuente encontrar flores estaminadas junto con frutos maduros). Para mencionar algunos casos extremos: de las 22 muestras de Apodanthera ulei estudiadas para esta tesis sólo una de ellas tenía flores carpeladas y otras dos frutos; contrariamente, entre los 13 especímentes disponibles para $A$. trifoliata, sólo uno presenta flores estaminadas, mientras que los demás tienen flores carpeladas y frutos con distinto grado de desarrollo. Para algunas de las especies no se conocen aún las flores carpeladas, en $A$. cinerea, por ejemplo, sólo se conoce el tipo que consta de inflorescencias estaminadas y frutos); esta situación ha favorecido la presunción, equivocada, de que muchas de estas especies son dioicas.

\section{Raíz}

Las raíces de Apodanthera son tuberosas, engrosadas, reservantes (xilopodios) y representan una adpatación a ambientes áridos, donde la absorción y acumulación de agua es particularmente difícil; entre las especies estudiadas se reconocen 3 tipos:

a) En las especies de la sección Pseudoapodanthera, endémica del nordeste de Brasil, los tubérculos son de naturaleza radical-caulinar, involucrando el cuello de la planta y una porción de longitud variable, tanto de raíz como de tallo (la tuberización afecta a la porción basal del tallo). La porción superior de este xilopodio queda expuesta sobre el suelo y de ella emergen varias ramas o tallos subleñosos (Figura 8A, 8D). Algunos autores se refieren a este tipo de xilopodio como "paquipodio" (Kocyan et al. 2007, Machado 2009, Paiva Lima 2010, Schaefer \& Renner 2011b), probablemente por ocurrir unos similares en especies del género Pachypodium Lindl. (Apocynaceae) de África. Esta estructura se ha observado en otras familias de enredaderas tropicales (por ejemplo, Dioscoraceae o Vitaceae), dentro de la tribu Coniandreae en los géneros Corallocarpus Welw., Doyerea Grosourdy, Ibervillea Greene, Kedrostis Medic y Seyrigia Keraudren; el género Dendrosicyos Balf. f., con una única especie de porte arbóreo, es considerado como un caso extremo.

b) Un estudio del sistema radical de Apodanthera undulata (Dittmer \& Talley 1964), de América del Norte, reveló que la raíz principal se bifurca a escasa profundidad, casi en ángulo recto, creciendo las ramas en direcciones opuestas y que a su vez vuelven a bifurcarse en modo similar (Figura 8B). Este sistema de ramificación le permite optimizar la superficie de absorción en la porción superficial del suelo (hasta $1 \mathrm{~m}$ de profundidad), la porción que contiene la poca humedad proveniente de las escasas precipitaciones. Las raíces alcanzan gran tamaño y desarrollo; en el mencionado estudio se ha indicado que el sistema radicular comprendido en un radio de 2 metros puede pesar cerca de 60 y que 


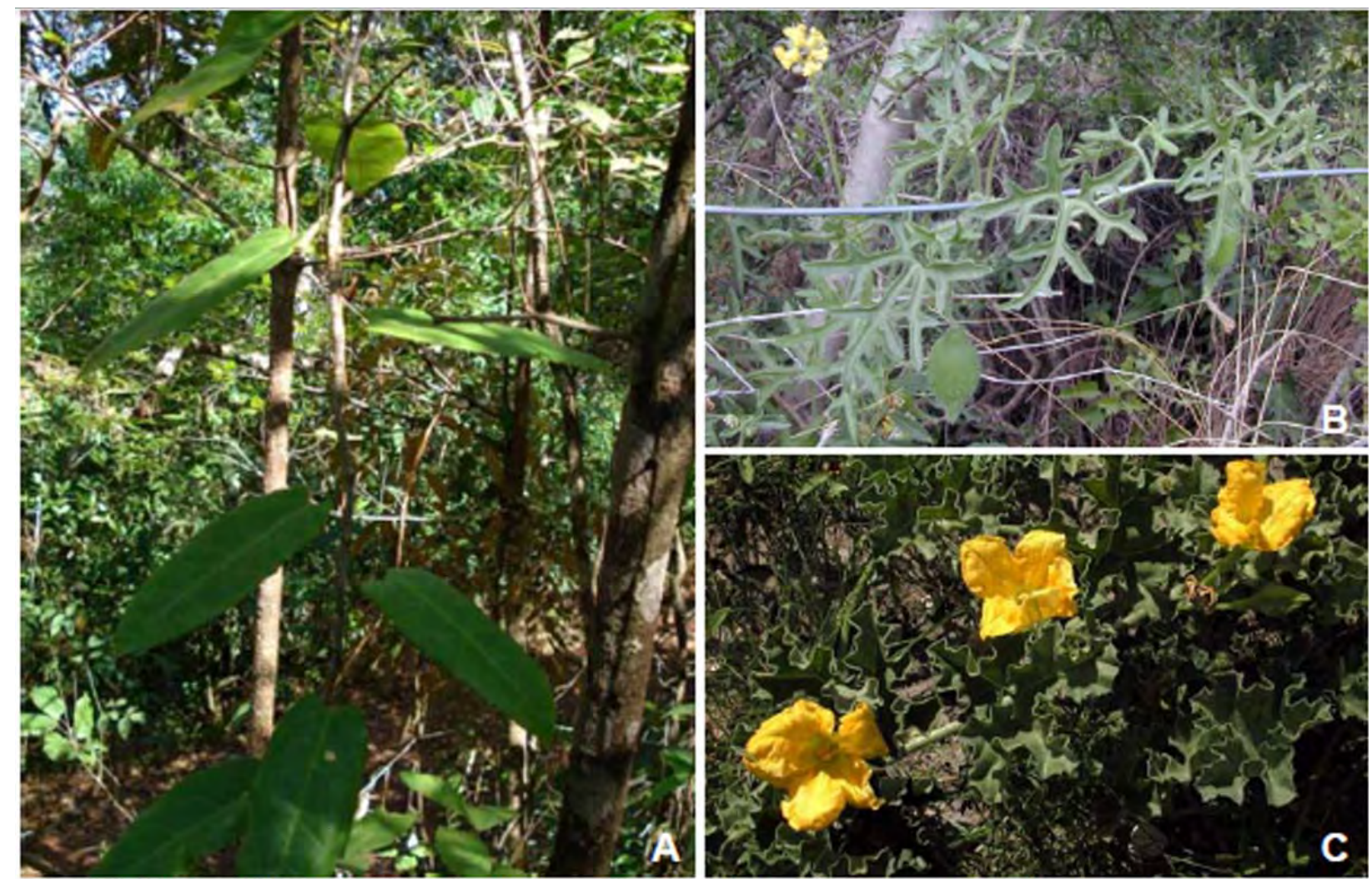

Figura 7. Hábito. A. Apodanthera smilacifolia (liana). B. Apodanthera sagittifolia (enredadera). C. Apodanthera aspera (rastrera). (A de Paiva Lima 2010; B foto de M. J. Belgrano, de Pozner 253, Sl; C foto de Pedro Tenorio-Lezama 2001).
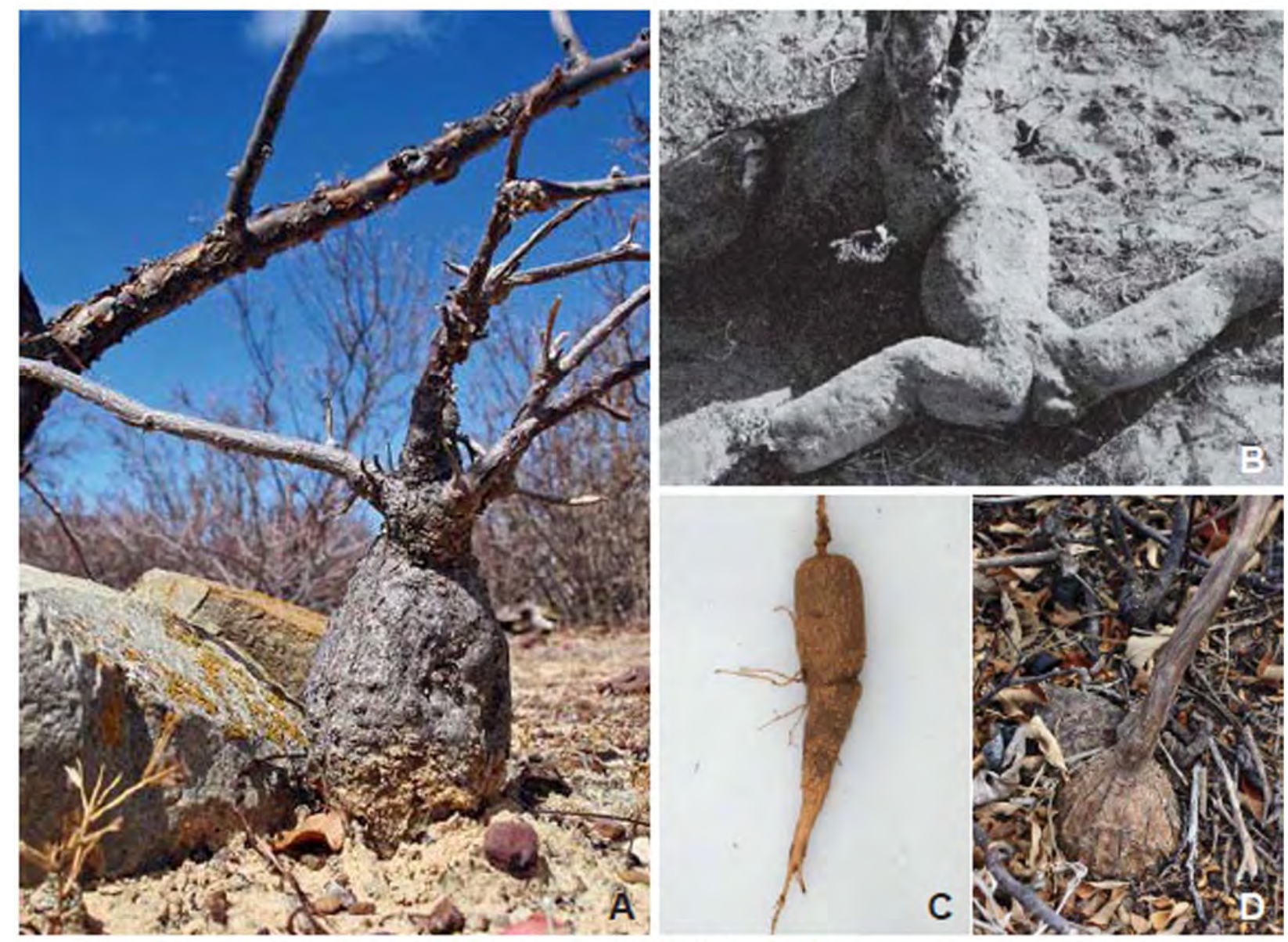

Figura 8. Raices tuberosas (xilopodios). A. Apodanthera trifoliata. B. Apodanthera undulata. C. Apodanthera sagittifolia. D. Apodanthera villosa. (A y D tomadas de Machado 2009; B de Dittmer \& Talley 1964. C foto de M. J. Belgrano, de Pozner \& Belgrano 257, SI). 
la raíz principal puede alcanzar un perímetro de $76 \mathrm{~cm}$. Del cuello de la planta emergen varios tallos leñosos, perennes, subterráneos, que son los que albergan las yemas de renuevo.

c) En las especies sudamericanas de la sección Apodanthera, la raíz tuberosa es típicamente napiforme, de ella crece un único tallo perenne, breve, subterráneo, del que emergen a su vez los tallos anuales (Figura 8C). Según Pozner (1998a), refiriéndose al sistema radical de Cucurbitella asperata, este tipo de estructura reservante está conformada por la raíz junto con el hipocótilo, los primeros nudos del epicótilo y la porción basal de las ramas de los años siguientes, por medio de su desarrollo secundario en diámetro. Este tipo de raíces se observan, por ejemplo, en Apodanthera sagittifolia y $A$. glaziovii. Las raíces de Apodanthera biflora, conocida en Perú como "yuca de monte" son comestibles, poseen un alto contenido de almidón y aceites escenciales.

\section{Tallos}

Como se indicó anteriormente, algunas especies desarrollan un tallo perenne (secc. Apodanthera) y otras varios (secc. Cucurbitopsis y Pseudoapodantera). Estos tallos perennes integran, junto con la raíz, el sistema reservante de la planta, son leñosos, subterráneos (secc. Apodanthera y Cucurbitopsis) o aéreos (secc. Pseudoapodanthera) y portan las yemas hibernantes para la próxima estación. De estas yemas surgen, durante los meses más cálidos, varios tallos anuales que se extienden por el suelo o trepando sobre la vegetacion circundante por medio de sus zarcillos. Estos tallos anuales pueden alcanzar varios metros de longitud y hasta de $7 \mathrm{~mm}$ de diámetro, son cilíndricos y estriados o ligeramente costados longitudinalmente. En las especies de la sección Pseudoapodanthera los tallos sufren a menudo desecamiento y absición al madurar los frutos (también los zarcillos y las hojas).

\section{Indumento}

En las especies estudiadas el indumento de los órganos vegetativos y las piezas florales es muy variado y ha sido utilizado por diversos autores con fines taxonómicos. Los tricomas se clasifican principalmente como glandulares o eglandulares y suelen ser distintos según se trate de órganos vegetativos o reproductivos (Inamdar \& Gangadhara 1975, Inamdar et al. 1989, Zimmermann 1922). Comúnmente las paredes celulares de los tricomas están calcificadas, observándose blancuzcos y algo rígidos.

A continuación se indican los distintos tipos de tricomas observados, su denominación (según Inamdar \& Gangadhara 1975), descripción y órgano en el que se encuentran (Figura 9):

Tricomas eglandulares multicelulares

1) Simples, uniseriados, filiformes. Tricomas diferenciados en una célula basal (o del pie) y un cuerpo uniseriado y filiforme, con células subiguales, todas ellas de grosor similar y superficie lisa. De este tipo básico de tricoma se han observado las siguientes variantes: 
a) Tricomas relativamente largos (7-12-celulares), con célula apical aguda o subulada, recta o ligeramente geniculada y primera célula del pedículo a menudo algo más gruesa, esta célula puede ser recta (resultando el tricoma patente y la superficie híspida o hirsuta) o estar arqueada hacia arriba (resultando el tricoma adpreso y la superficie tomentosa); se los observa, principalmente en los tallos anuales de algunas especies.

b) Tricomas muy largos y delgados, filiformes, con célula apical subulada, se los observa en el hipanto de las flores tanto estaminadas como carpeladas, en la superficie externa o interna, a menudo entrelazados, confiriendo un aspecto villoso o lanoso. Cuando estos tricomas se encuentran en el interior del hipanto conforman un "nectarostegio tricomatoso", pues funcionan como una cubierta que oculta el néctar de los polinizadores y reduce su evaporación.

c) Tricomas similares a los anteriores pero con las células del pedículo algo irregulares, con aspecto como de "falange", únicamente observados en la fauce del hipanto de algunas especies (Apodanthera ulei, por ejemplo); también se trata de un nectarostegio.

2) Cónicos con base unicelular. Tricomas uniseriados, cortos (4-6-celulares) y de paredes más gruesas, con célula apical aguda, a veces algo redondeada, patentes o adpresoascendentes, son los tricomas más comúnmente observados en hojas y tallos (Figura 9A).

3) Cónicos con base multicelular. Similares a los anteriores pero con una corona de células accesorias dispuestas alrededor de la célula basal, que sobresalen por sobre el nivel de la epidermis. Estos tricomas son frecuentes en tallos y hojas, usualmente entremezclados con otros tricomas con base unicelular. A menudo, la porción superior de estos tricomas es caediza, persistiendo sobre la superficie del órgano sólo la célula basal y la corona de células accesorias, y resultando el conjunto de aspecto cónico o dentiforme (sobre los tallos lucen como dentículos, sobre la lámina como puntuaciones). La abundancia relativa de estos tricomas confiere a la superficie del órgano mayor o menor aspereza y escabrocidad a la superficie. En la lámina foliar se ha observado que las células accesorias están a menudo coloreadas de castaño oscuro (Figura 9G-H).

4) Ramificados. Tricomas uniseriados divididos en ramas irregulares hacia el extremo superior (Figura 9D). Estos tricomas se han observados exclusivamnte en la cara externa de los pétalos de algunas especies y confieren a sus superficie un aspecto corto y densamente afelpado ( $A$. laciniosa, por ejemplo).

\section{Tricomas glandulares multicelulares}

1) Capitados (moruliformes) no explosivos. Tricomas con cuerpo diferenciado en un pedículo breve y una cabezuela pluricelular (Figura 9E). Estos tricomas se encuentran exclusivamente en la cara ventral de los pétalos y confieren aspecto punteado o granuloso a su superficie (están ausentes en las especies de la sección Pseudoapodanthera). 

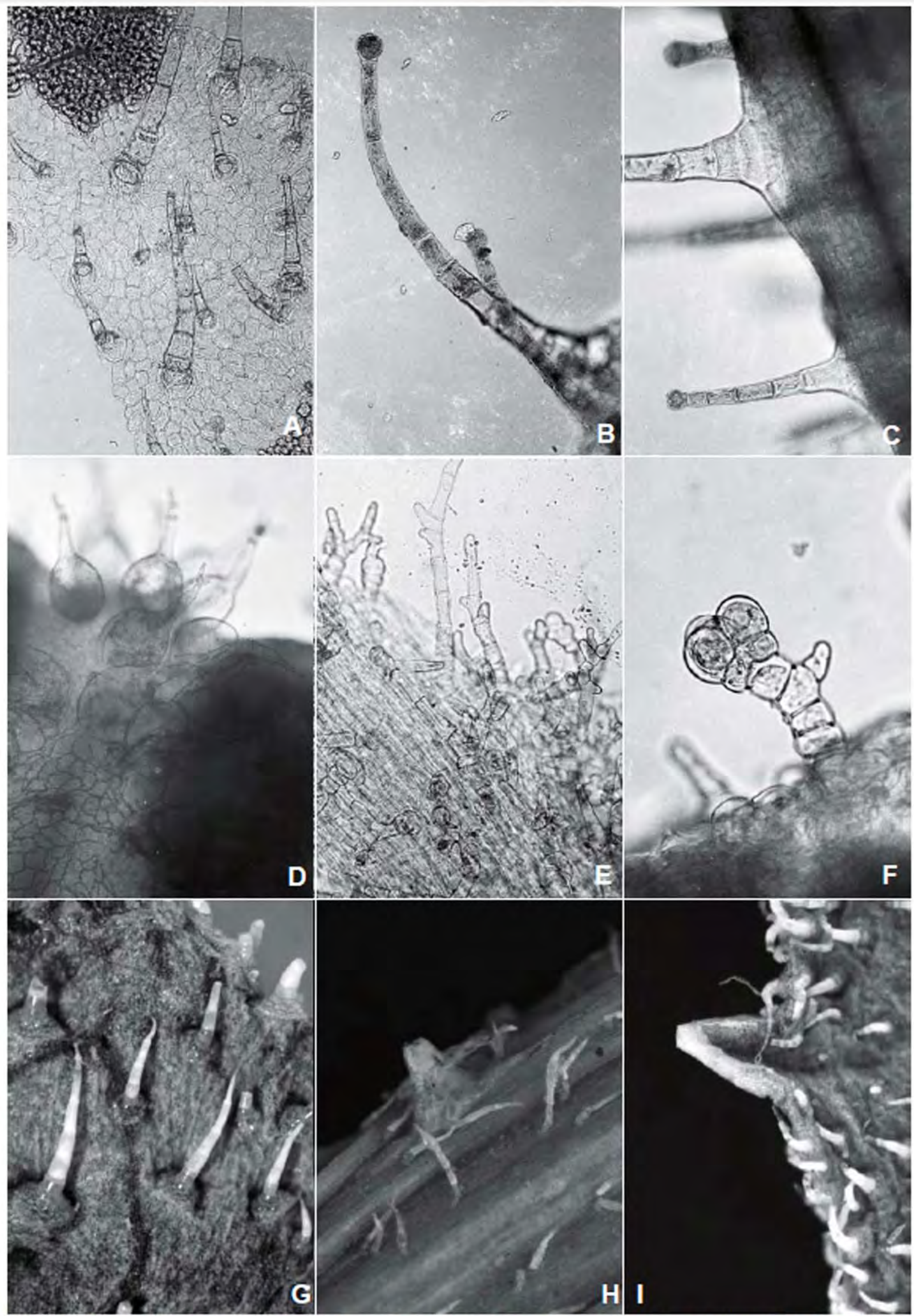

Figura 9. Tricomas. Apodanthera laciniosa. A. Tricomas eglandulares cónicos $\infty$ n base unicelular de la lámina foliar. B-C. Tricomas glandulares capitados, simples (explosivos) del hipanto. D. Tricomas glandulares ampuliformes (explosivos) del apice del conectivo. E. Tricomas eglandulares ramificados de la cara externa de los pétalos. F. Tricoma glandular capitado (moruliforme), de la cara intema de los pétalos. (A-E 100x; F 400x. Fotos M. J. Belgrano, de Smith et al. 10224, US). Apodanthera aspera. G. Tricomas eglandulares cónicos. con base plunicelular, de la cara abaxial de la lámina. H. Tricomas eglandulares filiformes y cónicos de base pluriceluar, del tallo. I. Hidátodo, cara ventral de la lámina (G-1 60x. Fotos M. J. Belgrano, G de Arsène 8301, GH: H-I de Harris 25724, GH). 
2) Capitados (simples) explosivos. Tricomas uniseriados de largo variable (3-6-celulares), con la primera célula del pedículo simple y célula apical subesférica, como una cabezuela de paredes delgadas y superficie lisa (Figura 9F-G). Estos tricomas pierden la célula apical cuando maduros (el resto del tricoma es persistente), liberando una secreción de olor desagradable. La primera célula del pedículo puede ser recta (y los tricomas patentes) o incurva (y los tricomas adpreso-ascendentes). Se los encuentra con mayor frecuencia en los pedicelos, hipantos y sépalos de las flores de ambos tipos (estaminadas y carpeladas), aunque en algunas especies también se los ha observado en estructuras vegetativas como tallos y hojas (característicos de la sección Apodanthera).

3) Ampuliformes explosivos. Tricomas 2-3-celulares, diferenciados en una célula basal (pie), una célula con forma de ampolla cuyo contenido actúa como aglutinante del polen, y una célula apical caediza que actúa como liberadora de ese contenido (Pozner, 1998a). Estos tricomas se encuetran exclusivamente en el conectivo de algunas especies ( $A$. weberbaueri o A. laciniosa, por ejemplo). Figura $9 \mathrm{H}$.

\section{Hojas}

En las especies de Apodanthera las hojas son simples o más raramente compuestas, pecioladas y de contorno variable: ampliamente ovado o subpentagonal, enteras, subenteras, poco o profundamente lobadas, palmatilobadas o palmatisectas ( $A$. mathewsii, A. mandonii y $A$. hirtella, por ejemplo); sagitado ( $A$. sagittifolia); hastado-triangular ( $A$. glaziovii); acorazonado ( $A$. argentea); suborbicular-reniforme, de margen entero o lobado, undulado o crispado, (secc. Cucurbitopsis) (Figura 10).

La consistencia de la lámina varía desde tenuemente membranácea ( $A$. tumbeziana) a subcrasa (secciones Cucurbitopsis y Pseudoapodanthera); probablemente este caracter esté sujeto a cuestiones ambientales (Pozner, 1998a). El indumento de pecíolos y láminas está conformado, principalmente, por tricomas cónicos con base unicelular y/o tricomas con base pluricelular persistente, usualmente adpresos, dispuestos en cantidades relativas desiguales, resultanto la superficie áspera, aspérula o leve a profusamente tomentosa; en la cara abaxial el indumento es más profuso que en la adaxial (la que algunas veces puede ser glabrescente).

En el margen de la lámina se observan hidátodos pluricelulares conectados con los nervezuelos foliares que se hallan en el ápice y en el extremo de sus dientes y lóbulos (Figura 91). Los hidátodos son órganos de secreción, responsables de la gutación, que lucen como dientecillos blanquecinos, más o menos conspicuos, subtriangulares, cóncavos vistos desde la cara abaxial de la lámina.

Para algunas especies ha podido constatarse dimorfismo foliar en un mismo individuo: en $A$. laciniosa se han observado, excepcionalmente, hojas de contorno acorazonado en una misma rama con las típicas hojas palmatilobadas; en $A$. trifoliata las hojas basales suelen ser enteras, mientras que las demás son trifoliadas. 


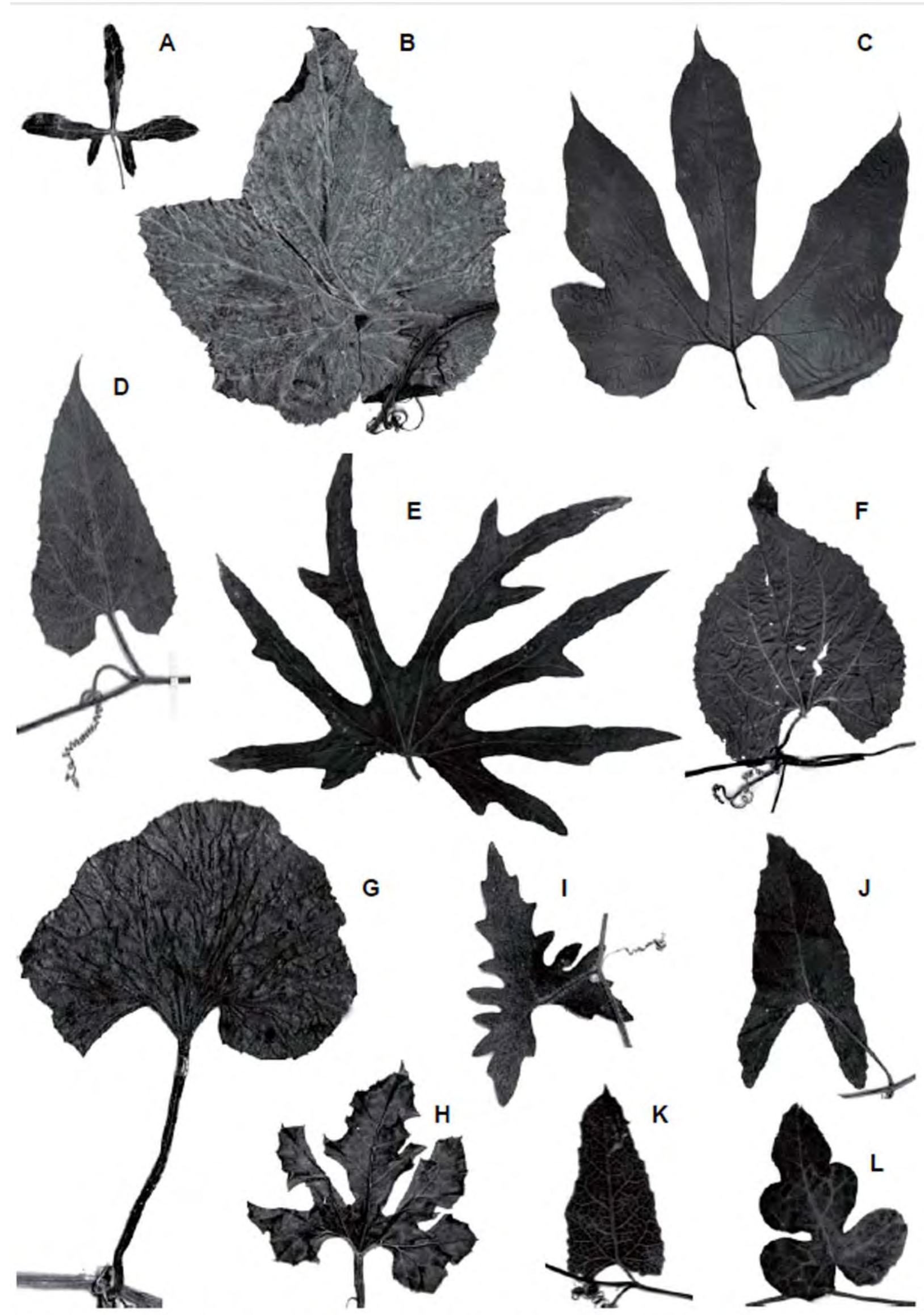

Figura 10. Variación foliar interespecifica. A. Apodanthera anatuyana (de Fuentes 2261 CTES). B. A. mathewsii (de Mathews 932 K). C. A. ulei (de Reitz 5019 CTES). D. A. argentea (de 9466 F). Variación foliar intraespecifica. E-F. A. laciniosa (de Krapovickas 43719 CTES y Rambo 34924 NY). G-H. A. aspera (de Palmer 281 NY y Palmer $345 \mathrm{GH}$ ). I-J. A. sagittifolia (de Pozner 257 SI y Schulz 7172 CTES). K-L. A. glaziovi (de Gpo. Pedra do Cavalho 372 CEPEC y Miranda 1246 CEPEC). 
Entre individuos distintos de la misma especie la variación foliar puede ser mucho más marcada (Figura 10E-L). Por citar algunos ejemplos: en $A$. aspera hay individuos con lámina foliar entera, de margen entero, y otros con lámina profundamente 5-lobada, con margen dentado; en $A$. mandonii algunos individuos tienen láminas 5-lobadas y otros 5-sectadas. La forma de la lámina foliar puede estar sujeta a las condiciones ambientales (Schaefer \& Renner, 2011b). Esta situación ha conducido a la fundación de gran cantidad de binomios.

\section{Zarcillos}

Los zarcillos tienen prefoliación recta y pueden ser simples (como ocurre con todas las especies de la sección Pseudoapodanthera y algunas especies de la sección Apodanthera, como A. glaziovii, por ejemplo) o compuestos, con 2 ramas (zarcillos 2 -fidos), a veces una de las ramas se divide a su vez en otras 2 (zarcillos 3-fidos). Los zarcillos simples son de naturaleza foliar, los compuestos tienen una porción caulinar, denominada portazarcillo, y una o más partes foliares (Kumazawa 1964). En los zarcillos compuestos las ramas se enroscan por encima del punto de bifurcación. El portazarcillo puede ser muy breve (sección Cucurbitopsis) o muy desarrollado (algunas especies de la sección sección Apodanthera) (Figura 11). Que los zarcillos sean simples o compuestos es de importancia taxonómica (Schaefer \& Renner, 2011b).
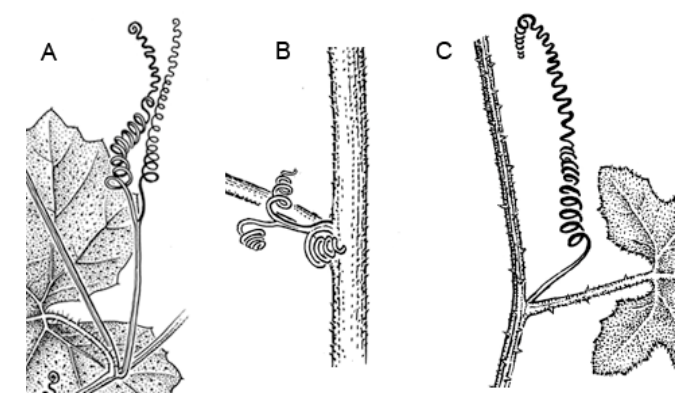

Figura 11. Zarcillos. A. Zarcillo compuesto, 2-fido, con portazarcillos alargado. B. Zarcillo compuesto, 3-fido, con portazarcillos breve. C. Zarcillo simple.

\section{Inflorescencias estaminadas y carpeladas}

No existen trabajos detallados sobre las inflorescencias de Cucurbitaceae; el tipo básico parece ser el monotélico (Schaefer \& Renner 2011b) y las unidades de floración pueden adquirir, por acortamiento o alargamiento relativo de los ejes, aspecto de inflorescencias abiertas o politélicas. Por este motivo, y como ocurre de manera frecuente en la literatura botánica (Rúa 1999), en esta tesis son descriptas como "racemiformes", "umbeliformes", etc.

En las secciones Apodanthera y Cucurbitopsis la inflorescencia estaminada pedunculada, en el inicio de su desarrollo tiene un aspecto umbeliforme o fasciculiforme y luego racemiforme por alargamiento de los entrenudos entre las flores. A menudo estos alargamientos no son conspicuos y la inflorescencia adquiere aspecto de umbela pedunculada (Figura 12A), otras veces tiene desarrollo variable y desigual (Figura 12B-C) o uniforme (Figura 12D). El pedúnculo 
es más o menos grácil, finamente estriado longitudinalmente, glabrescente a hirsútulo, erecto o ascendente, usualmente superando en largo a las hojas, de modo que las flores se asoman por encima del follaje. El número de flores en cada inflorescencia varía desde 1 ó 2 flores (como en A. biflora, por ejemplo), con flores largamente pediceladas (Figura $12 \mathrm{H}$ ), a más de 25 (como en A. laciniosa y $A$. mandonii) con pedicelos más cortos e inflorescencias de aspecto más tipicamente racemiforme (Figura 12D). A veces la inflorescencia tiene aspecto de fascículo pedunculado (como en $A$. aspera, por ejemplo), con pedicelos bien desarrollados (Figura 12E). Las flores carpeladas suelen aparecer solitarias; sin embargo, se interpretan aquí como la reducción de una inflorescencia pues no es raro que aparezcan también geminadas. Las flores carpeladas tienen usualmente un pedicelo desarrollado, que se extiende aún más durante la fructificación y son ebracteadas. Cuando inflorescencias de ambos tipos se hallan en un mismo tallo, usualmente lo hacen en nudos distintos, algunas veces son co-axilares (como en $A$. anatuyana y $A$. laciniosa, por ejemplo). En $A$. undulata las inflorescencias estaminadas suelen localizarse en los nudos proximales de los tallos y las carpeladas en los distales (Delesalle, 1992); en $A$. aspera, en cambio, se disponen en forma alternada en los nudos.

En la sección Pseudoapodanthera tanto la inflorescencia estaminada como la carpelada suelen ser subespiciformes con el eje muy breve, carnoso y densamente villoso-lanoso y con las flores sésiles o subsésiles (como en $A$. trifoliata, Figura 12F), o bien pueden ser fasciculiformes (Figura 12G), menos frecuentemente puede tener aspecto de racimo congesto, con el eje muy breve y las flores pediceladas (como en $A$. pedisecta). En todos los casos las inflorescencias de ambos tipos son plurifloras, excepcionalmente, en $A$. hindii, son paucifloras.
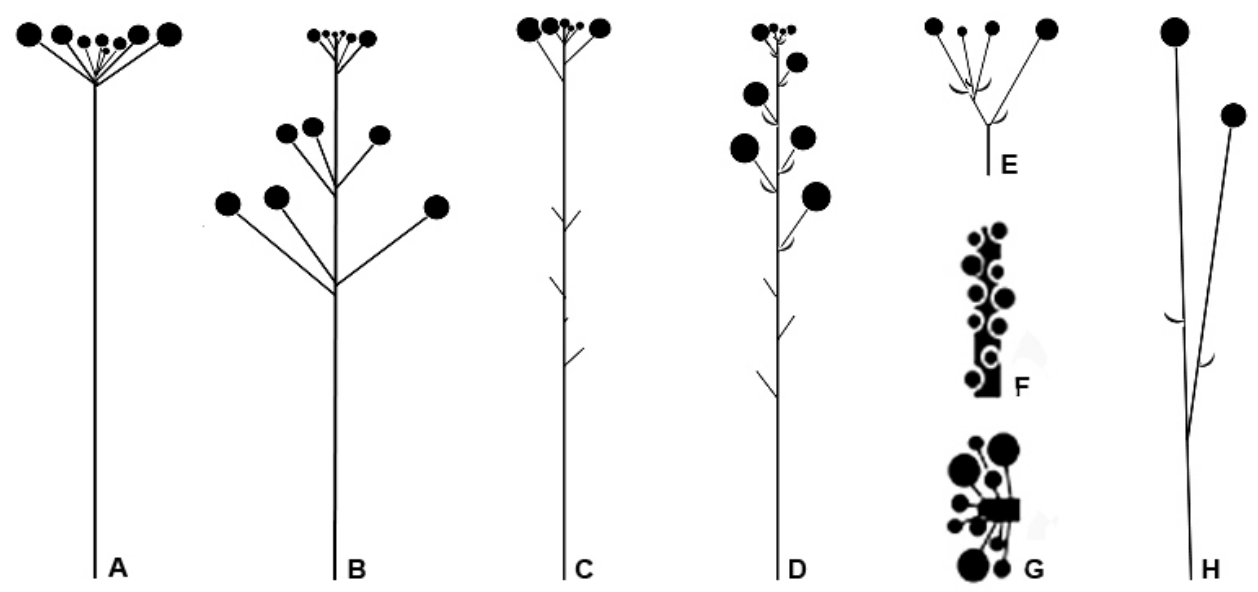

Figura 12. Inflorescencia estaminada, esquemas descriptivos. A. Inflorescencia umbeliforme, largamente pedunculada (Apodanthera weberbauerii). B. Inflorescencia racemiforme, los entrenudos entre las flores con crecimiento desigual (A. mathewsii). C. Inflorescencia racemiforme, los entrenudos entre las flores con crecimiento desigual, las flores basales han caído y persisten los pedicelos ( $A$. sagittifolia). D. Inflorescencia racemiforme, los entrenudos entre las flores se alargan más o menos uniformemente, las flores son bracteadas, las basales han caído (A. mandonii). E. Inflorescencia fasciculiforme pedunculada, flores bracteadas, largamente pediceladas ( $A$. aspera). F. Inflorescencia subespiciforme, con eje breve y carnoso y flores subsésiles ( $A$. trifoliata). G. Inflorescencia fasciculiforme, inconspicuamente peduncualda, flores pediceladas ( $A$. fasciculata). H. Inflorescencia 2-flora, flores bracteadas, largamente pediceladas (A. biflora). 
En este punto cabe mencionar que los esquemas presentados en la Figura 12 son púramente descriptivos y tienen por objeto ilustrar la descripción de las inflorescencias; de ningún modo pretenden ser interpretativos. Un estudio interpretativo del desarrollo de las inflorescencias de las especies de Apodanthera excede el alcance de esta tesis.

\section{Flores estaminadas}

Las flores estaminadas son pediceladas, corta o largamente, y los pedicelos glabrescentes, hispídulos, hírtulos o hirsuto-tomentosos, erectos o algo flexuosos, persistentes luego de caídas las flores y a menudo algo recurvos, algunas veces con una marca de absición notable en el ápice del pedicelo (por ejemplo en $A$. laciniosa). Pueden ser bracteadas o ebracteadas. Las brácteas, cuando presentes, suelen desarrollarse hacia la base del pedicelo, son lineares o lanceoladas y más pequeñas que las flores. El hipanto puede ser acampanado o subcilíndricoinfundibuliforme (subcilíndrico, ensanchándose hacia el ápice), la base atenuada hacia el pedicelo o redondeada, exteriormente puede ser glabro o glabrescente, hispídulo, hirsuto, pubérulo o villoso (a veces lanoso en los pimpollos), interiormente puede ser glabro o villoso en distintas posiciones (en la porción media, en el tercio superior o en la fauce). En la base interior del hipanto suele desarrollarse un nectario mesenquemático cupuliforme, sólido y algo craso (como se observa en $A$. mathewsii, A. undulata, A. villosa y A. weberbaueri, entre otras), formado por tejido del mesofilo (Pozner 1993, Vogel 1997). Algunas especies carecen de este nectario y poseen, en esa posición, un pistilodio emergente de origen carpelar (Pozner 1993), glanduliforme, hemiesférico o subcolumnar, libre de la pared del hipanto (por ejemplo, $A$. glaziovii y $A$. sagittifolia); en algunas especies no se observa nectario ni pistilodio ( $A$. anatuyana y $A$. trifoliata, por ejemplo). Excepcionalmente (sólo observado en $A$. cinerea) el hipanto se prolonga hacia la base en un pie tubular, muy angosto y hueco, que corresponde a un pistilodio de origen hipantial (Pozner 1993), con dos pequeñas protuberancias en el ápice interior de esta invaginación del hipanto. El hipanto suele ser de color verde, excepto en algunas de las especies brasileras de la sección Pseudoapodanthera, en las que es de color amarillo. El cáliz es de prefoliación abierta o más raramente valvar y los sépalos pueden ser subtriangulares, lanceolados o subulados, con indumento y coloración que se corresponden con aquellos del hipanto, a veces son algo recurvados luego de la antesis. La corola es de prefoliación imbricada y los pétalos de vernación induplicada o plano-induplicada (sólo en las especies de la sección Pseudoapodanthera), libres hasta prácticamente la base, de contorno elíptico, elítico-lanceolado, ovado-elíptico o suborbicular, más cortos que el hipanto, menos frecuentemente de largo similar al hipanto y muy vistosos (como ocurre en las especies de la sección Cucurbitopsis), ápice agudo a obtuso, redondeado o emarginado, a menudo mucronado, de margen entero o levemente crenado, de color amarillo pálido o brillante a anaranjados, con 3-5(-7) venas principales, corta y densamente afelpado-villosos en la cara externa, más raramente glabrescentes (en las especies de la sección Pseudoapodanthera), 
interiormente punteado-glandulares, con tricomas moruliformes, más o menos abundantes, raramente hispídulos o glabrescentes (Pseudoapodanthera). El androceo está conformado por 3 estambres, 2 ditécicos y 1 monotécico, insertados en el tercio superior del hipanto o en la fauce, resultando más o menos exertos; las anteras son dorsifijas (en algunas especies la inserción del filamento se produce en la porción basal del conectivo y parecen ser basifijas, como en $A$. argentea), subcuadradas, elipsoides u oblongo-elipsoides, de dehiscencia longitudinal; los filamentos son muy breves, a menudo glabros, más raramente con algunos tricomas cortos; el conectivo hialino, angosto o algo expandido, entero o escotado en el ápice y/o la base, glabro o tricomatoso (tricomas ampuliformes en el ápice), rara vez ligeramente prolongado en el ápice ( $A$. trifoliata); las tecas son alantoides o botuliformes, subiguales, rectas o apenas arqueadas, a veces marcadamente recurvadas sólo en el ápice y/o la base. Algunos ejemplos para ilustrar la morfología de las flores estaminadas se muestran en la Figura 13, a continuación.

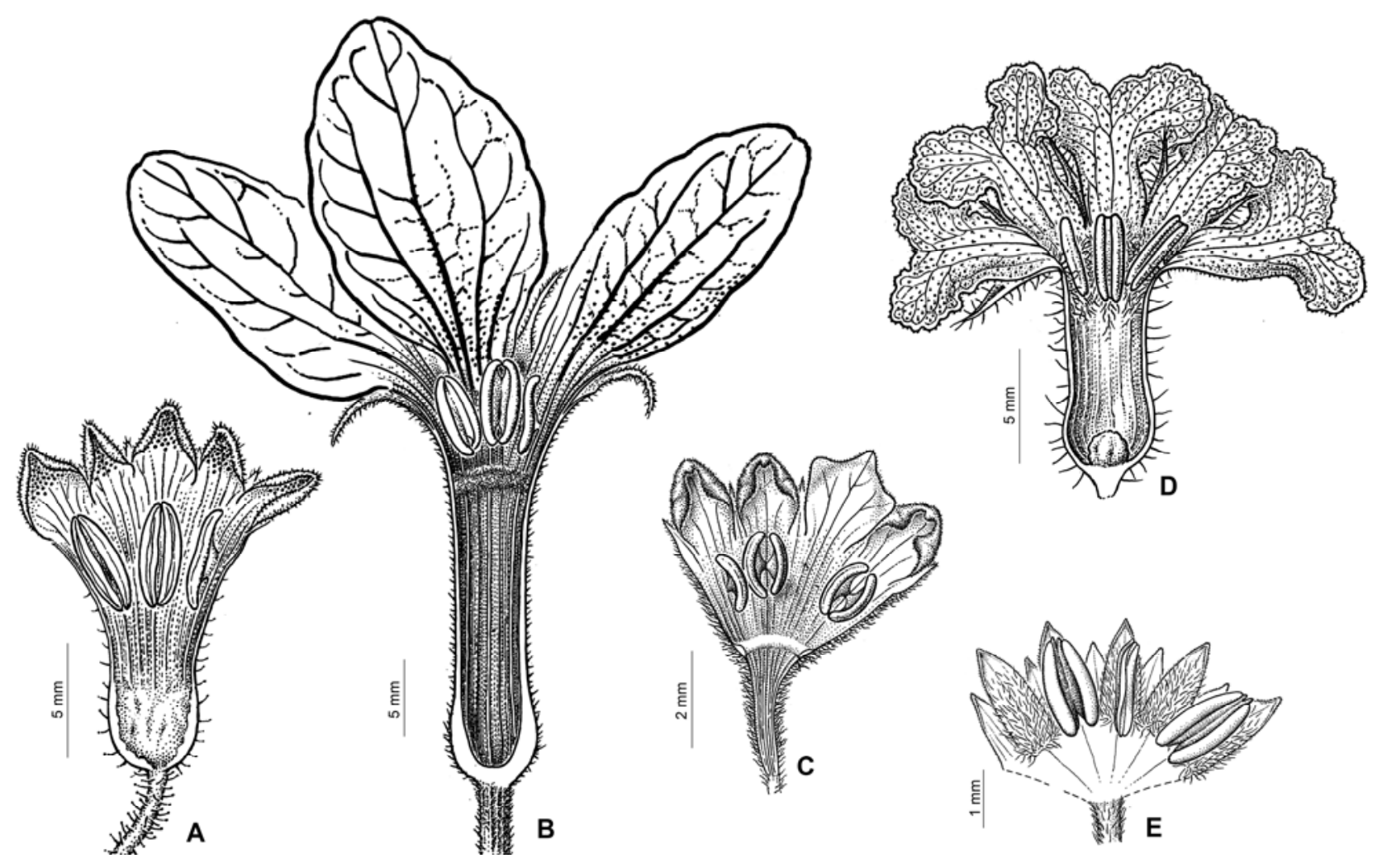

Figura 13. Flores estaminadas. A. Apodanthera mathewsii: hipanto subcilíndrico-infundibuliforme, interiormente glabro, con necatario mesenquemático en la base. B. Apodanthera undulata: hipanto largamente subcilíndricoinfundibuliforme, con una banda tricomatosa en su interior y nectario mesenquimático basal. C. Apodanthera cinerea: hipanto acampanado, interiormente glabro, con pistilodio hipantial (invaginación tubular en la base). D. Apodanthera sagittifolia: hipanto subcilíndrico-infundibuliforme, densamente villoso en la fauce, con pistilodio carpelar, emergente, hemisférico en la base. D. Apodanthera trifoliata: hipanto obcónico, densamente villoso en la fauce (la cara interna de los pétalos hispídulos), sin pistilodio ni nectario basal. 


\section{Polen}

Los trabajos referidos a los granos de polen de Apodanthera no son numerosos, entre ellos pueden mencionarse los de Marticorena (1963), Ayala Nieto et al. (1988), Quiroz García et al. (2003) y Paiva Lima (2010). Estos trabajos incluyen repesentantes de las 3 secciones del género y para todos ellos los resultados fueron similares: los granos de polen se hallan en mónades, son de forma variada (subprolados, prolados, suboblados, oblado-esferiodales o esferoidales), tricolporados y con exina reticulada o microrreticulada, como ocurre en la mayoría de los géneros de Coniandreae. Paiva Lima (2010) indicó que existe una correlación directa entre el tamaño de los granos de polen y el tamaño de la corola.

\section{Flores carpeladas}

Las flores carpeladas son pediceladas, más raramente sésiles o subsésiles (sección Pseudoapodanthera) y ebracteadas; el pedicelo es estriado longitudinalmente, glabrescente, pilósulo, hírtulo o hirsuto, alargándose durante la fructificación. El hipanto es cortamente cilíndrico, muy raramente tan breve que resulta casi anular (en A. trifoliata), el indumento y su coloración son análogos a aquellos de las flores estaminadas. El cáliz y la corola son similares a los de las flores estaminadas. Los estaminodios 3(-4)-5, son alternipetalos o en se ubican en posiciones intermedias, siempre insertados cerca de la fauce del hipanto, de formas diversas, mamiliformes, setiformes, anteriformes, cónicos con el ápice redondeado, subulados, erectos o curvados, enteros u obscuramente 2-lobulados, algunas veces aproximados de a pares, quedando uno de ellos desapareado. El ovario es fusiforme, angosta o anchamente elipsoide, redondeado en ambos extremos o sólo en la base, glabrescente, hírtulo, hirsuto o hirsutotomentoso (a veces lanoso en los pimpollos). El número de carpelos y placentas puede ser de 2 (en $A$. anatuyana y en la mayoría de las especies brasileñas), 3 (en $A$. biflora, A. laciniosa y A. hirtella) o (-4)-5 (en A. mathewsii, A. undulata y A. laciniosa, entre otras). El estilo es columnar, glabro, más raramente con algunos tricomas esparcidos, patentes. En algunas especies puede desarrollarse un nectario periestilar, anular, más o menos marcado en reborde (A. sagittifolia, por ejemplo). Apicalmente el estilo se divide en 2, 3 ó 5 ramas poco o muy notables. Algunos autores se refieren a las ramas del estilo como "estilodios" e interpretan a los estilos columnares como estilodios connados y que algunas veces es posible disgregarlos por simple tracción. Según Schaefer \& Renner (2011b) el número de estilodios es útil taxonómicamente, que los clados más derivados tienen un estilo simple con 2-3(-5) estigmas que pueden estar alargados simulando un androceo, probablemente para atraer a las abejas polinizadoras (Dukas 1987). Los estigmas son papilosos o fimbriados y están dispuestos en el extremo de cada una de las ramas del estilo, usualmente son 2-lobulados, con lóbulos en forma de "U", a veces obscuramente y algo subglobosos, otras veces los lóbulos son oblongoides. Los óvulos son anátropos y están dispuestos horizontalmente; pueden ser pocos (2-6 por placenta, en las especies de Pseudoapodanthera o en A. anatuyana, por ejemplo) o 
muy numerosos (sección Cucurbitopsis y las especies andinas de la sección Apodanthera). Algunos ejemplos de flores carpeladas se muestran en la Figura 14.
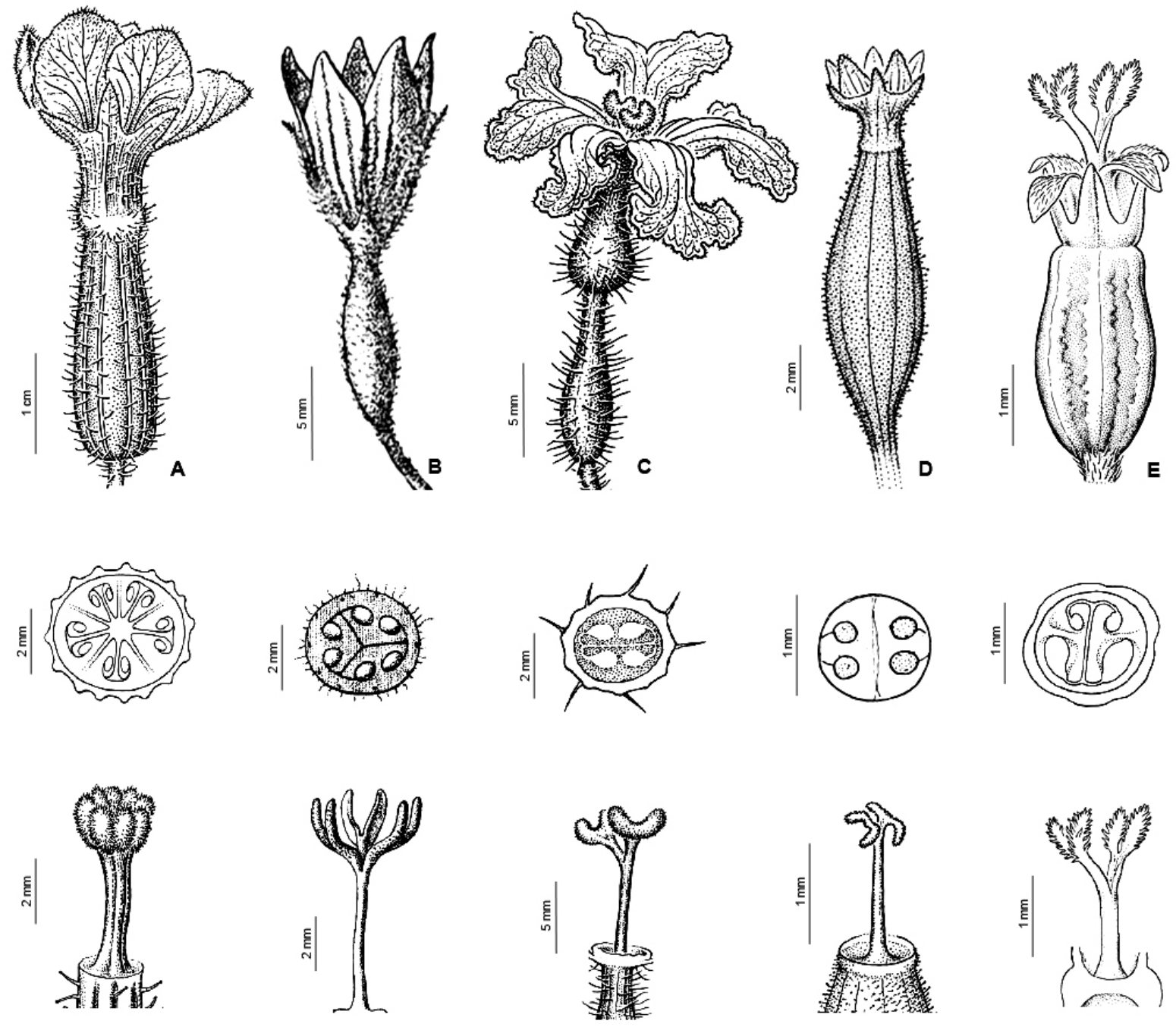

Figura 14. Flores carpeladas. Vista lateral, corte transversal del ovario y detalle del estilo y estigma. A. Apodanthera mathewsii: ovario 5-placentífero, lóbulos estigmáticos en forma de "U", papilosos. B. Apodanthera biflora: ovario 3-placentífero, lóbulos estigmáticos oblongoides, papilosos. C. Apodanthera sagittifolia: ovario 2placentífero, lóbulos estigmáticos oblongoides, papilosos. D. Apodanthera anatuyana: ovario 2-placentífero, lóbulos estigmáticos cortamente oblongoides. E. Apodanthera trifoliata: ovario 2-placentífero, lóbulos estigmáticos fimbriados.

\section{Frutos}

Los frutos son carnosos, típicamente una baya, pauci o pluriseminada, elipsoide o anchamente elipsoide, más raramente subesférica ( $A$. biflora y $A$. ferreyrana) u oblongoide ( $A$. laciniosa), de base usualmente redondeada o algo truncada y ápice redondeado o menos frecuentemente apiculado, rostrado. El epicarpo es liso o costado ( $A$. undulata), glabro o pubescente, de color verde con manchas más claras, verdoso-blanquecinas, dispuestas más o menos 
longitudinalmente y en forma algo interrumpida, que se torna amarillento o de color rojo intenso (A. anatuyana, A. ulei) cuando el fruto madura. El meso- y el endocarpo son fibrosomucilaginosos, de color verde o verde-amarillento. Los frutos de muchas especies alcanzan la madurez luego de que los tallos y hojas de esa temporada se han marchitado. En el herbario, los frutos de algunas especies se tornan algo leñosos (por ejemplo, A. laciniosa, A. mandonii y A. undulata). A modo ilustrativo se presentan algunos tipos de frutos en la Figura 15.
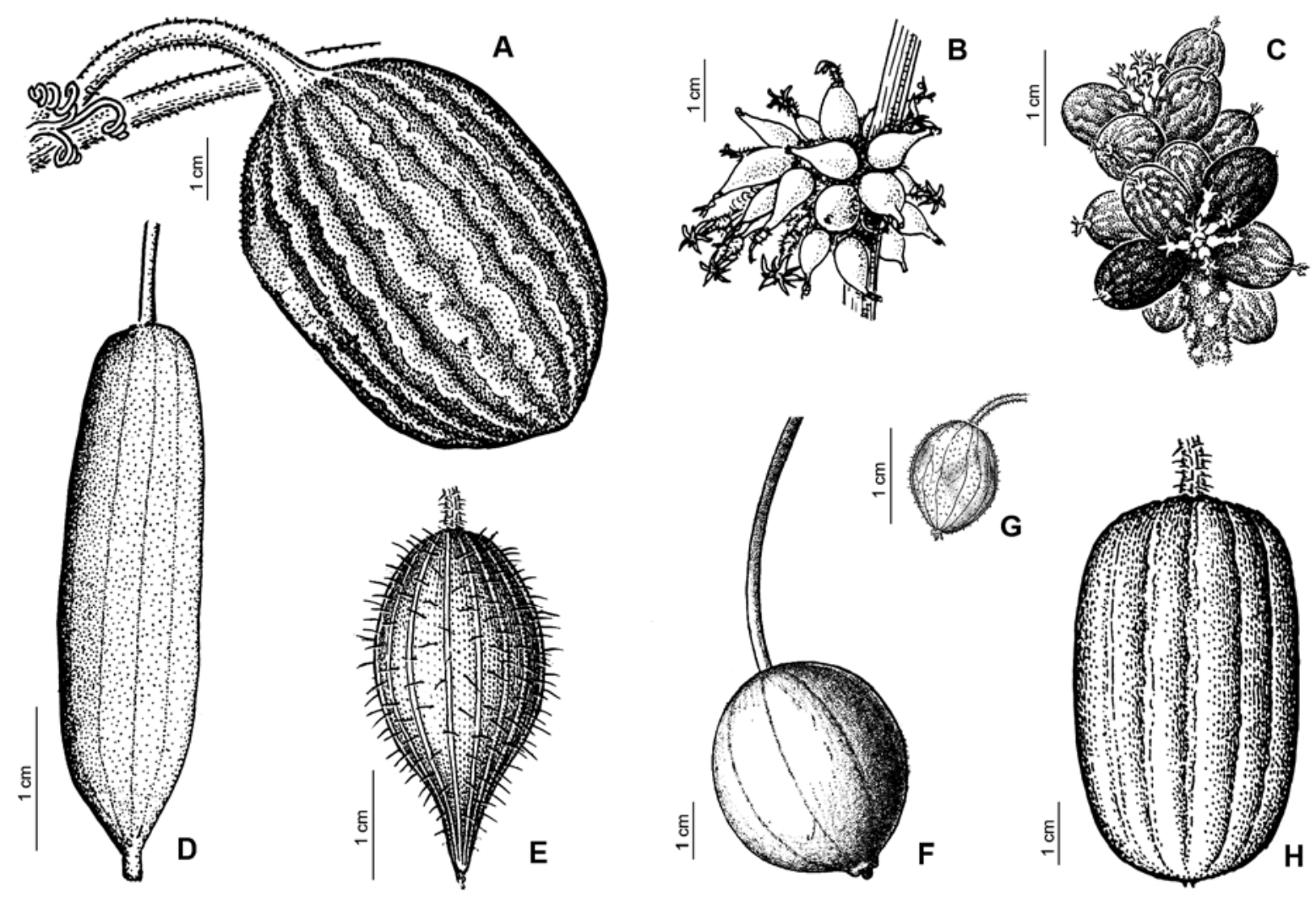

Figura 15. Frutos. A. Apodanthera undulata. B. Apodanthera villosa. C. Apodanthera trifoliata. D. Apodanthera laciniosa. E. Apodanthera sagittifolia. F. Apodanthera biflora. G. Apodanthera anatuyana. H. Apodanthera mathewsii.

\section{Semillas}

Las semillas son de contorno, superficie, borde y color variados (Figura 16):

a) Ovoides, ovado-elipsoides a suborbiculares, fuertemente comprimidas en el plano sagital, lisas, de color castaño, con un margen poco notable en relieve, de color blanco-cremoso (especies andinas de la sección Apodanthera y la sección Cucurbitopsis).

b) Piriformes, de superficie lisa o algo rugósula, castañas, castaño-grisáceas, emarginadas, excepto hacia la porción hilar donde el margen es un poco más notorio y más claro (sección Pseudoapodanthera).

c) Ovado-elipsoides, apenas o no comprimidas, emarginadas, de superficie lisa, castaño-claras o castaño pajizo (A. laciniosa, $A$. ulei). 


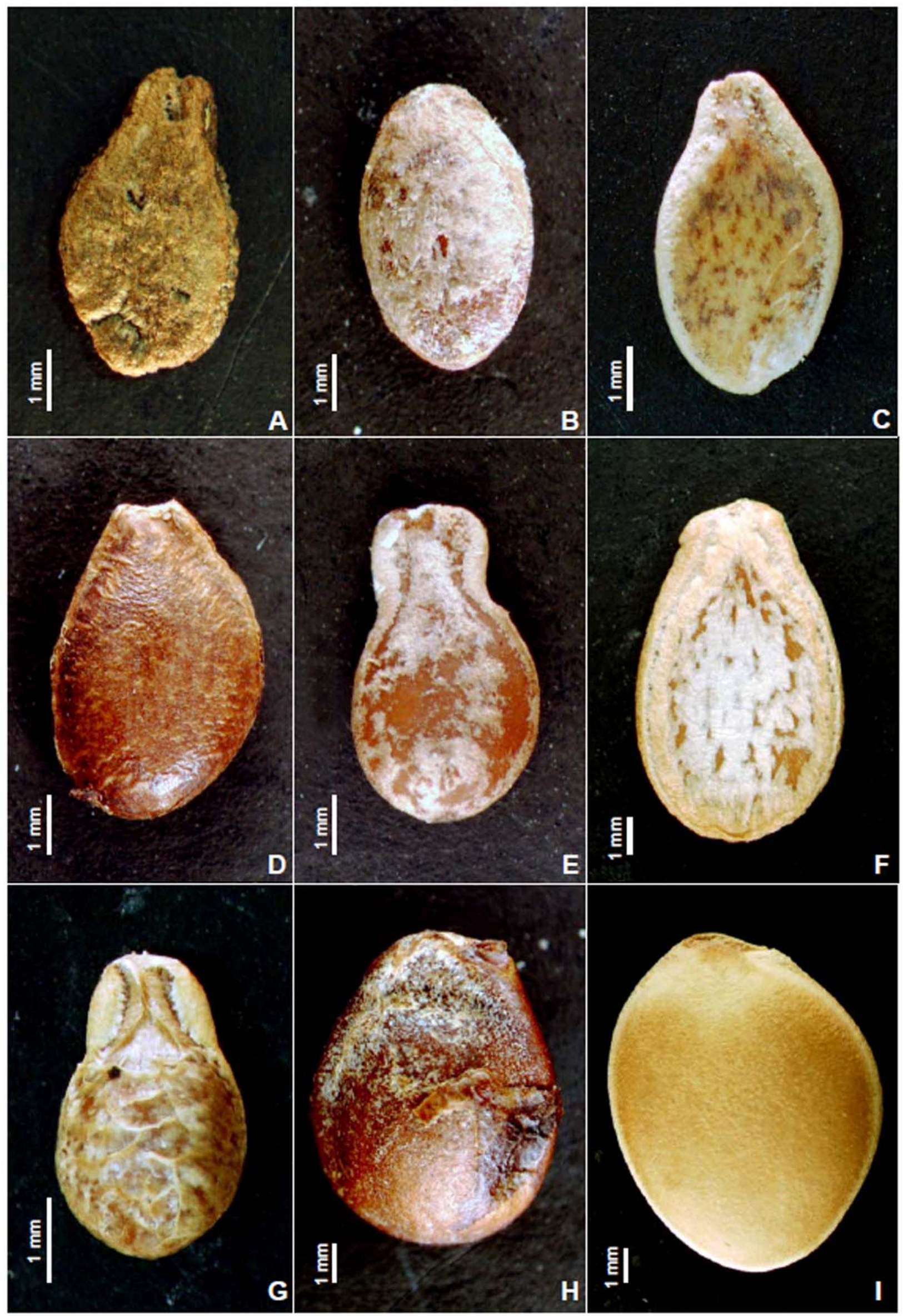

Figura 16. Semillas. A. Apodanthera anatuyana (de Burkart 20212, SI). B. Apodanthera laciniosa (de Rambo 31246 , LIL). C. Apodanthera mandonii (de Krukoff 22083, NY). D. Apodanthera palmenï (de Palmer 1444, NY). E. Apodanthera pedisecta (de Hatschbach 52706, CTES). F. Apodanthera sagittifolia (de Pedersen 13202, UC). G. Apodanthera trifoliata (de Harley 21534, NY). H. Apodanthera ulei (de Reitz 8606, US). I. Apodanthera undulata (de Pringle 48, GH). 
d) Ovoides, fuertemente comprimidas en el plano sagital, con superficie irregular, de color castaño-pajizo o castaño-negruzco, que se torna esponjosa al humedecerse ( $A$. anatuyana, $A$. cinerea, entre otras), algunos autores se refieren a esta cubierta como "pleurograma" (Gomes Klein 1996, Paiva Lima 2010).

Las semillas están envueltas por una porción del endocarpo, denominada "saco ariloideo", que se separa del resto del tejido del endocarpo y rodea a las semillas como si fuera un arilo (Pozner 1998a); éste saco ariloideo puede ser hialino o mucilaginoso, tornándose papiráceo cuando seco.

\section{Fenología}

La época de floración de las especies de Apodanthera está vinculada con los periodos de mayores temperaturas, según la región en la que crecen. Así, las especies del Hemisferio Norte (sección Cucurbitopsis) florecen y fructifican entre mayo y agosto, pudiendo extenderse hasta noviembre. Las especies que se extienden por los Andes y zonas templadas de Sudamérica, por el contrario, florecen desde octubre hasta abril (sección Apodanthera); las especies que ocupan áreas tropicales de Brasil y que no están marcadamente influidas por la elevación ( $A$. glaziovii, A. ulei, sección Pseudoapodanthera) pueden hacerlo durante todo el año. Probablemente, el comienzo de la floración se produzca luego de la época de lluvias en cada región. Se ha indicado que $A$. biflora, que crece en zonas costeras de Ecuador y Perú, florece a intervalos de varios años, en los meses de marzo y abril, luego de intensas lluvias. 


\section{Estudio filogenético}

Las filogenias publicadas más recientemente para la familia Cucurbitaceae se realizaron sobre la base de caracteres moleculares; en éstas se incluyeron representantes de todos los géneros y fueron utilizadas para ajustar el esquema clasificatorio infrafamiliar y redefinir los límites de las tribus y los géneros (Kocyan et al. 2007, Schaefer et al. 2009, Schaefer \& Renner 2011a).

En estas filogenias se consideraron muy pocos representantes de Apodanthera; en efecto, Kocyan et al. (2007) sólo incluyeron a A. mandonii, Schaefer et al. (2009) a A. mandonii y A. sagittifolia, mientras que Schaefer \& Renner (2011a) a $A$. anatuyana y $A$. sagittifolia. Ningún representante de las secciones Cucurbitopsis y Pseudoapodanthera fueron incluidos en estos análisis. En esta tesis se aportan datos moleculares para 16 especies de Apodanthera, representantes de sus tres secciones e incluyendo a la especie tipo $A$. mathewsii (Tabla 1 ).

El objetivo de este estudio filogenético fue poner a prueba la monofilia de Apodanthera esclarecer la posición de sus especies y de los géneros afines dentro de la tribu Coniandreae; se utilizaron caracteres morfológicos y moleculares, considerados en forma independiente y combinada (evidencia total) (Nixon \& Carpenter 1996).

\subsection{Materiales y Métodos}

Para la reconstrucción de la filogenia se llevó a cabo un análisis cladístico basado en el criterio de máxima parsimonia. Este análisis incluyó un total de 45 especies, los "terminales". El grupo interno (InGroup) estuvo conformado por 23 especies de Apodanthera aceptadas como independientes en esta tesis y representantes de todos los demás géneros de la tribu Coniandreae. Cabe mencionar que Apodanthera longipedicellata no fue incluida en el estudio filogenético por tratarse de un taxón dudoso (veáse discusión en el Capítulo 4). El grupo externo (OutGroup) incluyó representantes de los géneros Melothria L., de la tribu Benincaseae, grupo hermano de Coniandreae (Schaefer \& Renner, 2011a) y Bryonia L. (tribu Bryonineae), que se utilizó para enraizar el árbol. Se atendieron las recomendaciones de Nixon \& Carpenter (1993) para esta elección del outgroup. En todos los casos, de ser posible, se incluyó a las especies tipo de cada género.

\section{Caracteres moleculares}

Los datos moleculares obtenidos y utilizados en esta tesis corresponden a secuencias de ADN de dos regiones de cloroplasto: a) en gen rbcL completo, que codifica la enzima ribulosa-1, 5bifosfato carboxilasa oxigenasa (Rubisco), utilizando los "primers" (cebadores) descriptos en 
Zurawski et al. (1981); b) el espaciador trnL-F, que incluye el intrón trnL, una porción del exón trnL y el espaciador intergenérico entre los genes trnL y trnF, utilizando los primers descriptos en Teberlet et al. (1991). Estos mismos genes fueron utilizados (junto con otros) en las filogenias moleculares más recientes para Cucurbitaceae. Como se mencionó anteriormente, muchas de las secuencias se obtuvieron durante esta tesis, las restantes se tomaron de GenBank (http://www.ncbi.nlm.nih.gov/genbank/), el detalle se presenta en la Tabla 1.

Para el material fresco obtenido en el campo, y deshidratado en sílica gel, la extracción de ADN se llevó a cabo según el protocolo de Doyle \& Doyle (1987). Cuando no fue posible utilizar material fresco, las extracciones se realizaron sobre especímenes de herbario, en estos casos, se utilizó DNeasy Plant Mini Kit (Qiagen).

Las reacciones de amplificación por PCR se realizaron en un volumen final de $25 \mu \mathrm{l}$ con 50-100 ng de ADN molde, 0,2 $\mu \mathrm{M}$ de cada primer, $25 \mu \mathrm{M}$ de DNTPs, $5 \mu \mathrm{M} \mathrm{MgCl2,1X}$ buffer y 1,5 unidades de Taq polimerasa suministrada por "Invitrogen". Las condiciones en las que se efectuaron las reacciones fueron: período inicial de desnaturalización a $94^{\circ} \mathrm{C}$ durante 5 minutos, seguidos por 35 ciclos de desnaturalización a $94^{\circ} \mathrm{C}$ durante 30 segundos, pegado del primer a $48^{\circ} \mathrm{C}$ durante 1 minuto y extensión a $72^{\circ} \mathrm{C}$ durante 1 minuto 30 segundos; finalmente, una extensión a $72^{\circ} \mathrm{C}$ durante 6 minutos. Para cada serie de amplificaciones se incluyó un control negativo sin molde con el objeto de evidenciar, y descartar, posibles contaminaciones. Los productos de PCR se corrieron sobre un gel con TBE de agarosa al 1\% teñido con Sybr Gel. La secuenciación automática se llevó a cabo en "Macrogen, Inc."

Las secuencias obtenidas fueron editadas y ensambladas mediante el programa "BioEdit" version 5.0.9 (Hall, 1999). Las alineaciones se realizaron manualmente debido a que no se encontraron inserciones o deleciones de longitudes ambiguas. Cuando la amplificación falló para un fragmento o para la secuencia completa, las posiciones fueron codificadas como datos faltantes en las matríces independientes y combinadas, respectivamente.

\section{Caracteres morfológicos}

Se consideraron 35 caracteres morfológicos, todos ellos discretos, de los cuales 20 son binarios y 15 multiestado. Una descripción morfológica más detallada de las estructuras puede encontrarse en el Capítulo 2.

Los caracteres y sus homologías primarias (estados) se detallan a continuación.

1. Vástago: 0. Herbáceo. 1. Leñoso.

2. Hojas: 0. Ausentes. 1. Presentes simples. 2. Presentes compuestas. 
No se han codificado otros caracters foliares, como el contorno general de la lámina o la presencia de lóbulos, porque los mismo son muy variables intraespecíficamente (véase Capítulo 2). Contrariamente, algunos autores han indicado que las hojas simples poseen un control genético diferente al de las hojas compuestas (Efroni et al. 2010, Moon \& Hake 2011).

3. Zarcillos, presencia: 0. Ausentes. 1. Presentes simples. 2. Presentes compuestos (en al menos uno de los nudos del espécimen estudiado).

4. Zarcillos, prefoliación: 0. Recta. 1. Circinada.

5. Inflorescencia estaminada, pedúnculo: 0. Desarrollado. 1. Reducido: las inflorescencias son sésiles o casi sésiles (como en un glomérulo, por ejemplo).

6. Inflorescencia estaminada, eje: $\mathbf{0}$. Se alarga a medida que maduran las flores (la inflorescencia adquiere el aspecto de un racimo laxo). 1. No se alarga o sólo muy brevemente (la inflorescencia adquiere aspecto umbeliforme, fasciculiforme o de racimo congesto, por ejemplo).

7. Flor estaminada, pedicelo: $\mathbf{0}$. Desarrollado, como en los racimos o umbelas, por ejemplo. 1. Breve o reducido: cuando las flores son sésiles o casi sésiles (como en una espiga, por ejemplo).

8. Flor estaminada, bráctea: $\mathbf{0}$. Presente (al menos en una flor del espécimen estudiado). 1. Ausente.

9. Hipanto de la flor estaminada, forma: 0. Acampanado u obcónico. 1. Subcilíndricoinfundibuliforme. 2. Reducido, casi nulo.

10. Hipanto de la flor estaminada, pubescencia interior del ápice: 0. Glabro o glabrescente. 1. Con pubescencia copiosa (villosa o lanosa) en la fauce, conformada por tricomas eglandulares, simples, filiformes; se conoce a esta zona de pubescencia como "nectarostegio tricomatoso" pues funciona como una cubierta que oculta el néctar de los polinizadores y reduce su evaporación.

11. Hipanto de la flor estaminada, pubescencia interior de la zona media: 0. Glabro o glabrescente. 1. Con pubescencia copiosa (villosa o lanosa) por debajo de la zona de inserción de los filamentos estaminales; en las flores donde el hipanto es más largamente cilíndrico estos tricomas pueden disponerse a modo de "banda" a media altura del hipanto (probablemente tengan también la función de ocultar el néctar).

12. Hipanto de la flor estaminada, pubescencia exterior: 0. Glabro o glabrescente. 1. Con tricomas eglandulares, simples, filiformes, con célula apical aguda. 2. Con tricomas glandulares, simples, capitados, explosivos. 3. Con tricomas eglandulares, simples, filiformes, con célula apical uncinada.

13. Hipanto y cáliz de la flor estaminada, color: 0. Verde. 1. Amarillo. 2. Rojo 
14. Cáliz de la flor estaminada, prefloración: 0. Abierta. 1. Valvar.

15. Corola de la flor estaminada, prefloración: 0. Valvar. 1. Imbricada.

16. Pétalos, vernación y margen: $\mathbf{0}$. Induplicada: pétalos con lóbulos laterales (usualmente muy reducidos) que se pliegan sobre su cara adaxial. 1. Plana: pétalos sin lóbulos. 2. Circinada: pétalos partidos en el ápice, lóbulos circinados sobre su cara adaxial. 3. Involuta: pétalos con lóbulos laterales involutos.

17. Pétalos de la flor estaminada, indumento interno: $\mathbf{0}$. Glabro o glabescente. 1. Con tricomas eglandulares, uniseriados (confieren aspecto piloso o cortamente villoso). 2. Con tricomas glandulares, moriliformes, no explosivos (confieren aspecto punteado).

18. Pétalos de la flor estaminada, color: $\mathbf{0}$. Amarillo-Anaranjado (incluye amarillos pálidos y amarillento-verdoso). 1. Blanco. 2. Verde. 3. Rosado.

19. Androceo, estructura: 0. 2+2: dos anteras ditécicas. 1. 2+2+1: dos anteras ditécicas + una antera monotécica. 2. 1+1+1+1+1: cinco anteras monotécicas.

20. Estambres, posición: 0. Base del hipanto (hipanto de base de K y C). 1. 1/2-1/3 superior del hipanto (hipanto mixto). 2. Fauce del hipanto (hipanto de bases de K, C y A). La posición de los estambres establece la homología entre los hipantos: cuando los estambres son basales, el hipanto involucra la elongación intercalar de la base de los sépalos y de los pétalos; cuando son apicales (cerca de la garganta) incluye también la base de los estambres (Pozner 1993).

21. Anteras: 0. Dorsifijas. 1. Basifijas.

22. Tecas: 0. Flexuosas. 1. Rectas o apenas arqueadas.

23. Conectivo, indumento del ápice: 0. Glabro. 1. Con tricomas eglandulares, uniseriados, cortos y robustos. 2. Con tricomas glandulares, ampuliformes, explosivos. 3. Con pequeñas papilas.

24. Conectivo, indumento del margen: 0. Glabro. 1. Con tricomas eglandulares, filiformes, algo arqueados (como "pestañas"), que rodean a las tecas por todo su perímetro.

25. Pistilodio: 0. Ausente. 1. Con pistilodio carpelar, emergente (glanduliforme, hemisférico o subcolumnar), los bordes no están adheridos a la pared interna del hipanto. 2. Con pistilodio hipantial, con forma de invaginación tubular en la base de la flor. La homología se establece al conocer que la primera fase de formación del gineceo comienza con una invaginación del receptáculo que luego se transformará en el ovario (Pozner 1993).

26. Inflorescencia carpelada, pedúnculo: 0. Desarrollado: con pedúnculo más o menos alargado. 1. Reducido: cuando las inflorescencias son sésiles o casi sésiles (como en los glomérulos, por ejemplo). 
27. Flor carpelada, pedicelo: 0. Desarrollado, como ocurre en un racimo, por ejemplo. 1. Reducido o nulo: las flores son sésiles o casi.

28. Cantidad de flores carpeladas por inflorescencia: 0. 1 ó 2. 1. Más de 2 flores.

29. Ovario, número de placentas: 0. 2. 1. 3. 2. 5 (excepcionalmente 4).

30. Estaminodios: 0. Ausentes. 1. Presentes, en igual número que los estambres. 2. Presentes, en mayor número que los estambres. No se codifica el número de estaminodios porque en algunos casos no son independientes del número de estambres; sí importa, en cambio, la diferencia entre el número de estambres y de estaminodios porque indica si el apareamiento de los estambres es congénito o posgénito (Pozner 1993).

31. Estigma, lóbulos: 0. Enteros. 1. Lobulados.

32. Fruto: 0. Indehiscente. 1. Dehiscente.

33. Semillas cantidad: 0. Pocas (hasta 12). 1. Muchas (ca. 20 ó más).

34. Semilla, compresión: 0. Comprimidas en el plano sagital. 1. No comprimidas.

35. Semilla, superficie del tegumento: 0. Lisa. 1. Escrobiculada. 2. Irregular, como envuelta en una capa densa que se torna esponjosa al humedecerse.

El material de herbario estudiado, y utilizado para el estudio filogenético, se presenta en el Apéndice II. Para las especies del OutGroup se estudiaron las muestras disponibles en el herbario de Instituto Darwinion (SI); cuando no hubo especímenes disponibles, los datos para completar la matriz morfológica se tomaron de las siguientes fuentes bibliográficas: Acevedo Rodríguez (2005), Cogniaux (1878, 1916), Dieterle (1976), Gomes-Klein (1996), Grosourdy (1864), Kearns (1994a, 1994b), Keraudren (1966, 1975), Jeffrey (1967, 1992), Jeffrey \& Fernández (1986), Jeffrey \& Trujillo (1992), Martínez Crovetto (1947, 1949, 1954c, 1960), Pozner (1998a, 1998b), Schaefer \& Renner (2011b), Steele (2010).

\section{Análisis cladístico}

Los análisis de parsimonia se llevaron a cabo utilizando el progama TNT (Goloboff et al., 2008), bajo pesos iguales. Los caracteres fueron considerados en forma desordenada. Los caracteres no informativos fueron excluidos del análisis. Se realizaron búsquedas heurísticas de 1000 series de secuencias de adición al azar, seguidas de re-arreglo (swapping) de ramas utilizando TBR (Tree Bisection and Reconnection) y reteniendo 10 árboles por serie. Los árboles obtenidos fueron guardados en la memoria; adicionalmente, se realizó el re-arreglo o "swaping" de ramas con TBR reteniendo un máximo de 20000 árboles.

Las ramas con longitudes ambiguas de 0 ó 1 fueron colapsadas, según la regla de colapsamiento número 1. Se generaron árboles de consenso estricto (Nelson, 1979; Rohlf, 1982) a partir de los árboles más parsimoniosos. 
El soporte de ramas se calculó mediante el remuestreo de Jacknife, expresado como frecuencias absolutas. El re-muestreo consistió en 10000 réplicas y búsquedas heurísticas de 10 series de secuencias de adición, re-acomodadas (swapped) con TBR y guardando 2 árboles por serie.

Optimización de caracteres

Se llevó a cabo el mapeo de algunos caracteres morfológicos sobre los árboles obtenidos en el análisis combinado (de evidencia total); se utilizó el comando "Common Synapomorphies" de TNT, con el cual las optimizaciones compartidas por los árboles más parsimoniosos se representan en el árbol de consenso para determinar si se trata de caracteres sinapomórficos u homoplásicos.

\subsection{Resultados y discusión}

\section{Información molecular obtenida}

De los 45 taxones evaluados, sólo se consiguió información molecular para 37 de ellos, para 21 fue tomada de GenBank, para los restantes 16 obtenida en esta tesis (Tabla 1). Estos 37 taxones cuentan con secuencias completas de rbcL (se alinearon 1341 posiciones), entre éstos, sólo 30 cuentan también con secuencias de trnL-F (se alinearon 834 posiciones).

Se intentó extraer y amplificar ADN de los taxones restantes (enumerados al pie de la Tabla 1) pero sin éxito, en todos los casos, a partir de ejemplares de herbario antiguos y/o de baja calidad para hacer amplificaciones (por ejemplo, especímenes que fueron tratados con soluciones de bicloruro de amonio para su conservación). 
Tabla 1. Lista de los taxones y genes secuenciados con sus números de acceso en GenBank (se indica con "nueva" a las secuencias aportadas en esta tesis), ejemplares de herbario y procedencias geográficas. Para las especies de Apodanthera se indica la sección a la que pertenecen ( $\mathrm{A}=$ Apodanthera, $\mathrm{C}=$ Cucurbitopsis, $\mathrm{P}=$ Pseudoapodanthera). Con $\left({ }^{\star}\right)$ se indican las especies tipo de cada género y/o los géneros monotípicos.

\begin{tabular}{|c|c|c|c|c|}
\hline Taxón & Voucher & Origen & rbcL & trnL-F \\
\hline Apodanthera anatuyana (A) & Fuentes \& Navarro 2261 (CTES) & Santa Cruz, Bolivia & Nueva & \\
\hline Apodanthera aspera (C) & Huerta 105 (TEX) & Jalisco, México & Nueva & Nueva \\
\hline Apodanthera biflora (A) & Weberbauer 5944 (US) & Ecuador. Piura & Nueva & \\
\hline Apodanthera cinerea $(\mathrm{A})$ & Ule $6759(\mathrm{~K})$ & Loreto, Perú & Nueva & \\
\hline Apodanthera ferreyrana (A) & Ferreyra 8628 (MO) & La Libertad, Perú & Nueva & \\
\hline Apodanthera glaziovii (A) & Amorim 3889 (CEPEC) & Bahia, Brasil & Nueva & Nueva \\
\hline Apodanthera laciniosa (A) & $\begin{array}{l}\text { Lima } 367 \text { (SI) } \\
\text { Weigend \& Weigend 2000/165 }\end{array}$ & Rio Grande do Sul, Brasil & Nueva & Nueva \\
\hline Apodanthera mandonii (A) & $(\mathrm{M})$ & Cuzco, Perú & DQ535782 & DQ536787 \\
\hline Apodanthera mathewsii $(A)\left({ }^{\star}\right)$ & Nee \& Solomon 36663 (LPB) & La Paz, Bolivia & Nueva & \\
\hline Apodanthera palmeri (C) & Vaughn 637 (MO) & Sonora, México & Nueva & Nueva \\
\hline Apodanthera pedisecta $(P)$ & Souza $5154(F)$ & Minas Gerais, Brasil & Nueva & \\
\hline Apodanthera sagittifolia (A) & Pozner 257 (SI) & Córdoba, Argentina & Nueva & Nueva \\
\hline Apodanthera trifoliata $(P)$ & Amorim 3845 (CEPEC) & Bahia, Brasil & Nueva & Nueva \\
\hline Apodanthera undulata (C) & Reina 97-772 (TEX) & Sonora, México & Nueva & Nueva \\
\hline Apodanthera villosa (P) & Amorim 3880 (CEPEC) & Bahia, Brasil & Nueva & \\
\hline Bambekea racemosa $(*)$ & Louis $13283(\mathrm{M})$ & Congo & DQ535783 & DQ536788 \\
\hline Bryonia alba $\left(^{*}\right)$ & Volz 6 (M) & Alemania. Saxony & DQ535744 & DQ533867 \\
\hline Ceratosanthes palmata $\left(^{*}\right)$ & Chase $919(\mathrm{~K})$ & Venezuela. Maracaibo & DQ535788.1 & DQ536795.1 \\
\hline Corallocarpus bainesii & Schmidt et al. 2294 (MO) & Zambia & DQ535795 & DQ536801 \\
\hline Cucurbitella asperata $(*)$ & Nee et al. 48807 (MO) & Bolivia & DQ535748.1 & DQ536809.1 \\
\hline Dendrosicyos socotranus $\left({ }^{*}\right)$ & Lavranos s.n. (M) & Yemen. Socotra & AY973018.1 & AY973005 \\
\hline Doyerea emetocatharctica $(*)$ & Lira 471 (MO) & México & DQ535808.1 & DQ535870.1 \\
\hline Eureiandra formosa $\left(^{*}\right)$ & Lebrun 2929 (M) & Congo & DQ535812 & DQ641905a \\
\hline Gurania spinulosa $\left({ }^{\star}\right)$ & Cotton 1742 (AAU) & Ecuador & DQ535815.1 & DQ536822.1 \\
\hline Halosicyos ragonesei $\left({ }^{*}\right)$ & Vervoors $3589(\mathrm{G})$ & Argentina. Catamarca & DQ535755.1 & DQ535871.1 \\
\hline Helmontia leptantha $\left(^{*}\right)$ & $\begin{array}{l}\text { (1) Liesner } 6673(\mathrm{MO}) \\
\text { (2) Oldeman B } 4301(\mathrm{P})\end{array}$ & $\begin{array}{l}\text { (1) Venezuela } \\
\text { (2) Guayana Francesa }\end{array}$ & (1)DQ353757 & (2)DQ661616 \\
\hline Ibervillea lindheimeri $\left({ }^{*}\right)$ & Kearns s.n. & USA. Texas & DQ535821.1 & DQ536830.1 \\
\hline Kedrostis nana & Chase $274(\mathrm{~K})$ & África & DQ535824.1 & DQ536834.1 \\
\hline Melothria pendula $\left({ }^{\star}\right)$ & Cotton et al. 1741 (AAU) & Ecuador & DQ535828 & DQ536839.1 \\
\hline Melothria warmingii & Morrone 4887 (SI) & La Paz, Bolivia & Nueva & Nueva \\
\hline Melothrianthus smilacifolius $\left({ }^{\star}\right)$ & Irwin et al. 28197 (MO) & Brasil & DQ535764.1 & DQ535881.1 \\
\hline Psiguria racemosa & Culta MO, BG no 1997-2683-2 & Venezuela & DQ535735.1 & DQ536852.1 \\
\hline \multirow{2}{*}{$\begin{array}{l}\text { Seyrigia humbertii } \\
\text { Trochomeriopsis diversifolia }\left(^{\star}\right)\end{array}$} & \multirow{2}{*}{$\begin{array}{l}\text { Culta MO, BG no 1996-3485 } \\
\text { Sukkulentensam. Zurich } 82 \\
3861 / 0\end{array}$} & Madagascar & AY968526.1 & AY973010.1 \\
\hline & & Madagascar & DQ535859.1 & DQ536878.1 \\
\hline \multirow{2}{*}{$\begin{array}{l}\left.\text { Tumamoca macdougalii ( }{ }^{\star}\right) \\
\text { Wilbrandia ebracteata var. } \\
\text { bracteata }\end{array}$} & Reichenbacher 1646 (MO) & USA. Arizona & DQ535860.1 & DQ536879.1 \\
\hline & Belgrano 400 (SI) & Misiones, Argentina & Nueva & \\
\hline Wilbrandia verticillata & Luetzelburg 12002 (M) & Brasil. Rio de Janeiro & DQ535861 & DQ536881.1 \\
\hline
\end{tabular}

Nota: no se cuenta con información molecular para las siguientes especies: Apodanthera argentea, A. eriocalyx, $A$. fasciculata, A. hindii, A. hirtella, A. tumbeziana, A. ulei y A. weberbauerii. 
Tabla 2. Información morfológica obtenida. Matriz de caracteres morfológicos.

\begin{tabular}{|c|c|c|c|c|c|c|c|c|c|c|c|c|c|c|c|c|c|c|c|c|c|c|c|c|c|c|c|c|c|c|c|c|c|c|c|}
\hline & & 2 & 3 & 4 & 5 & 6 & 7 & 8 & 9 & 10 & 11 & 12 & 13 & 14 & 15 & 16 & 17 & 18 & 19 & 20 & 21 & 22 & 23 & 24 & 25 & 26 & 27 & 28 & 29 & 30 & 31 & 32 & 33 & 34 & 35 \\
\hline Apodanthera anatuyana & 0 & 1 & 1 & 0 & 0 & 0 & 0 & 0 & 0 & 1 & 0 & 2 & 0 & 0 & $?$ & 0 & 0 & 0 & 1 & 2 & 0 & 1 & 0 & 0 & 0 & 0 & 1 & 0 & 0 & 1 & 1 & 0 & 0 & 0 & 2 \\
\hline Apodanthera argentea & 0 & 1 & 1 & 0 & 0 & 1 & 0 & 0 & 1 & 1 & 0 & 1 & 0 & 0 & 1 & [01] & 2 & 0 & 1 & 2 & 0 & 1 & 1 & 0 & 1 & 0 & 1 & 0 & 0 & 2 & 1 & 0 & 1 & 1 & 0 \\
\hline Apodanthera aspera & 0 & 1 & 2 & 0 & 0 & 0 & 0 & 0 & 1 & 1 & 0 & 1 & 0 & 0 & 1 & 0 & 2 & 0 & 1 & 2 & 0 & 1 & 1 & 0 & 0 & 0 & 1 & 01 & [12] & 2 & 1 & 0 & 1 & 0 & 0 \\
\hline Apodanthera biffora & 0 & [01] & 1 & 0 & 0 & 0 & 0 & 0 & 11 & [01] & 1 & 1 & 0 & 0 & 1 & 0 & 2 & 0 & 1 & 1 & 0 & 1 & 0 & 0 & 0 & & 1 & & 11 & [12] & & & & & 0 \\
\hline Apodanthera cinerea & 0 & 1 & 1 & 0 & 0 & 0 & 0 & 1 & 0 & 0 & 0 & 1 & 0 & 0 & 1 & 0 & 0 & 0 & 1 & 1 & 0 & 1 & 0 & 0 & 2 & 0 & 1 & 0 & ? & $?$ & ? & 0 & 1 & 0 & 2 \\
\hline Apodanthera eriocalyx & 0 & 1 & 2 & 0 & 0 & 0 & 0 & 1 & 1 & 0 & 0 & 1 & 0 & 0 & $i$ & 0 & 2 & 0 & 1 & 1 & 0 & 1 & 0 & 0 & 0 & 0 & 1 & 0 & 2 & 2 & 1 & 0 & 1 & 0 & 0 \\
\hline Apodanthera fasciculata & [01] & [12] & 1 & 0 & 1 & 1 & 0 & 1 & 1 & 0 & 1 & 0 & 1 & 0 & 0 & [01] & 0 & 0 & 1 & 1 & 0 & 1 & 0 & 0 & 0 & 1 & 1 & 1 & 0 & 1 & 1 & 0 & 0 & 1 & $?$ \\
\hline Apodanthera ferreyrana & 0 & 1 & 2 & 0 & 0 & 0 & 0 & 1 & 1 & 0 & 0 & 2 & 0 & 0 & 1 & 0 & 2 & 0 & 1 & 1 & 0 & 1 & 0 & 0 & 0 & 0 & 1 & 0 & 2 & 2 & 1 & 0 & 1 & 0 & 0 \\
\hline Apodanthera glaziovii & 0 & 1 & 1 & 0 & 0 & 1 & 0 & 1 & 1 & 1 & 0 & 1 & 0 & 0 & 1 & 0 & 2 & 0 & 1 & 2 & 0 & 1 & [01] & 0 & 1 & 0 & 1 & 0 & 0 & ? & 1 & 0 & 1 & ? & \\
\hline Apodanthera hindii & 0 & 1 & 1 & 0 & 1 & 1 & 0 & 1 & 1 & 0 & 1 & 1 & 1 & 0 & 0 & [01] & 0 & 0 & 1 & 2 & 0 & 1 & 0 & 0 & 0 & 1 & 1 & 1 & 0 & 1 & 1 & 0 & 0 & 1 & 0 \\
\hline Apodanthera hirtella & 0 & 1 & 2 & 0 & 0 & 0 & 0 & 1 & 1 & 0 & 0 & 2 & 0 & 0 & 1 & 0 & 2 & 0 & 1 & 1 & 0 & 1 & 0 & 0 & 0 & 0 & 1 & 0 & 1 & 1 & 1 & 0 & 1 & 0 & 0 \\
\hline Apodanthera laciniosa & 0 & 1 & 2 & 0 & 0 & 0 & 0 & 0 & 1 & 0 & 0 & 2 & 0 & 0 & 1 & 0 & 2 & 0 & 1 & 2 & 0 & 1 & 2 & 0 & 0 & 0 & 1 & 0 & 1 & 2 & 1 & 0 & 1 & 1 & 0 \\
\hline Apodanthera mandonii & 0 & 1 & 2 & 0 & 0 & 0 & 0 & 1 & 1 & 0 & 0 & 2 & 0 & 0 & 1 & 0 & 2 & 0 & 1 & 1 & 0 & 1 & 0 & 0 & 0 & 0 & 1 & 0 & 2 & 2 & 1 & 0 & 1 & 0 & 0 \\
\hline Apodanthera mathewsi & 0 & 1 & 2 & 0 & 0 & 0 & 0 & 1 & 1 & 0 & 0 & 2 & 0 & 0 & 1 & 0 & 2 & 0 & 1 & 1 & 0 & 1 & 0 & & 0 & 0 & 1 & 0 & 2 & 2 & 1 & 0 & 1 & 0 & \\
\hline Apodanthera palmeri & 0 & 1 & 2 & 0 & 0 & 0 & 0 & 0 & 1 & 1 & 0 & 1 & 0 & 0 & 1 & 0 & 2 & 0 & 1 & 2 & 0 & 1 & 1 & 0 & 0 & 0 & 1 & 0 & 2 & 2 & 1 & 0 & 1 & 0 & 0 \\
\hline Apodanthera pedisecta & [01] & 2 & 1 & 0 & [01] & 1 & 0 & 1 & 1 & 0 & 1 & 0 & 1 & 0 & 0 & [01] & 0 & 0 & 1 & 2 & 0 & 1 & 0 & 0 & 0 & 1 & 1 & 1 & 0 & 1 & 1 & 0 & 0 & 1 & 0 \\
\hline Apodanthera s: & 0 & 1 & 1 & 0 & 0 & 0 & 0 & 1 & 1 & 1 & 0 & 1 & 0 & 0 & 1 & 0 & 2 & 0 & 1 & 2 & 0 & 1 & 0 & 0 & 1 & 0 & 1 & 0 & 0 & 2 & 1 & 0 & 1 & 0 & 2 \\
\hline Apodanthera trifoliata & [01] & [01] & 1 & 0 & [01] & 1 & 0 & 1 & 2 & 1 & 0 & 0 & [01] & 1 & 0 & [01] & 1 & 0 & 1 & 2 & 0 & 1 & 0 & 0 & 0 & [01] & 1 & 1 & 0 & 1 & 1 & 0 & 0 & 1 & 1 \\
\hline Apodanthera tumbe & 0 & 1 & 2 & 0 & 0 & 0 & 0 & 1 & 1 & 0 & 0 & 1 & 0 & 0 & 1 & 0 & 2 & 0 & 1 & 1 & 0 & 1 & 0 & 0 & 0 & 0 & 1 & 0 & 21 & [12] & 1 & & 1 & ? & ? \\
\hline Apodanthera ulei & 0 & 1 & 2 & 0 & 0 & 0 & 0 & 1 & 0 & 1 & 0 & 2 & 0 & 0 & 1 & 0 & 0 & 0 & 1 & 2 & 0 & 1 & {$[02]$} & 0 & 0 & 0 & 1 & 0 & 0 & 1 & 1 & 0 & 0 & 1 & 0 \\
\hline Apodanthera undulata & 0 & 1 & 2 & 0 & 0 & 0 & 0 & 0 & 11 & [01] & 1 & 1 & 0 & 0 & 1 & 0 & 2 & 0 & 1 & 2 & 0 & 1 & 1 & 0 & 0 & 0 & 1 & 01 & [12] & 2 & 1 & 0 & 1 & 0 & 0 \\
\hline Apodanthera villosa & [01] & [12] & 1 & 0 & 1 & 1 & 0 & 1 & 1 & 0 & 1 & 1 & 1 & 0 & 0 & [01] & 0 & 0 & 1 & 2 & 0 & 1 & 0 & 0 & 0 & 1 & 1 & 1 & 0 & $i$ & 1 & 0 & 0 & 1 & 0 \\
\hline Apodanthera weberbaueri & 0 & 1 & 1 & 0 & 0 & 1 & 0 & 1 & 1 & 0 & 0 & 2 & 0 & 0 & 1 & 0 & 2 & 0 & 1 & 1 & 0 & 1 & 2 & 0 & 0 & 0 & 1 & 0 & 01 & [12] & 1 & 0 & 1 & 0 & 0 \\
\hline Bambekea racemosa & 0 & 1 & 2 & 0 & 0 & 0 & 0 & 0 & 2 & 0 & 0 & $?$ & 0 & 0 & ? & ? & 0 & 0 & 2 & 0 & 1 & 0 & 0 & & 0 & 0 & 0 & 1 & ? & 2 & 0 & 0 & 1 & 0 & 0 \\
\hline Bryoni: & 0 & 1 & 1 & 1 & 0 & 0 & 0 & 1 & 0 & 0 & 0 & 0 & 0 & 0 & ? & ? & 2 & 1 & 1 & 0 & 1 & 0 & 0 & 0 & 0 & 0 & 0 & 1 & 11 & [12] & 1 & 0 & 0 & 1 & 0 \\
\hline Ceratosanthes palmata & 0 & 1 & 1 & 0 & 0 & 1 & 0 & 1 & 1 & 0 & 0 & 2 & 0 & 0 & 1 & 2 & 0 & 1 & 1 & 2 & 0 & 1 & 0 & 0 & 0 & 01 & [01] ! & [01] & 0 & 1 & 1 & 0 & 0 & 1 & 0 \\
\hline Corallocarpus bainesii & 0 & 1 & 1 & 0 & 0 & 1 & 0 & 0 & 0 & 1 & 0 & 1 & 0 & 0 & ? & ? & 2 & 0 & 1 & 2 & 0 & 1 & 0 & 0 & 0 & 1 & 11 & [01] ! & [01] & 2 & 1 & 1 & 0 & 1 & 0 \\
\hline Cucurt & 0 & 1 & 1 & 0 & [01] & [01] & 0 & 0 & 1 & 1 & 0 & 3 & 0 & 0 & 1 & 3 & 2 & 0 & 1 & 2 & 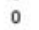 & 1 & 2 & & 0 & 0 & 1 & 0 & 2 & 2 & 1 & & 1 & 0 & 0 \\
\hline Dendrosicyos socotranus & 1 & 1 & 0 & ? & 1 & 1 & 0 & 0 & 1 & 0 & 0 & 1 & 0 & 0 & ? & $?$ & 0 & 0 & 1 & 2 & 0 & 1 & 0 & 0 & 0 & 0 & 1 & 0 & 1 & 2 & 1 & 1 & 1 & 0 & 0 \\
\hline Doyerea emetoc atharctica & [01] & 1 & 1 & 0 & [01] & 1 & 0 & 1 & 2 & 1 & 0 & [01] & 0 & 1 & 0 & [01] & 11 & [02] & 1 & 2 & 0 & 1 & 0 & 0 & 0 & [01] & 1 & 1 & 0 & 1 & 1 & 0 & 0 & 1 & 1 \\
\hline Eureiandra formosa & 0 & 1 & 1 & $?$ & 0 & 1 & 0 & 0 & 2 & 1 & 0 & 1 & 0 & 0 & $?$ & $?$ & 0 & 0 & 1 & 2 & 1 & 0 & 0 & 0 & 0 & 0 & 1 & 0 & 1 & [12] & 1 & & & 1 & 0 \\
\hline Gurania spinulosa & [01] ] & 1 & 1 & $?$ & 0 & 1 & 0 & 1 & 1 & 0 & 0 & 1 & 2 & 0 & $?$ & 0 & 0 & 0 & 0 & 1 & 0 & 1 & 3 & 0 & 0 & 1 & 0 & 1 & 0 & 0 & 1 & 0 & 1 & 0 & 0 \\
\hline Halosicyos ragonesei & 0 & 1 & 1 & 0 & 0 & 1 & 0 & 1 & 0 & 1 & 0 & 2 & 0 & 0 & ? & ? & 2 & 2 & 1 & 2 & 0 & 1 & 0 & & 0 & 0 & 1 & 0 & 0 & 2 & 1 & 0 & 0 & 1 & 0 \\
\hline Helmo & 0 & [12] & 1 & 0 & 0 & 0 & [01] & 1 & 1 & 0 & 0 & 0 & 0 & 0 & ? & ? & 2 & 1 & 0 & 2 & 0 & 1 & & & 1 & ? & ? & ? & 0 & $?$ & $?$ & & & 0 & 0 \\
\hline Ibervillea lindheimeri & 0 & 1 & 1 & 0 & 0 & 0 & 0 & 0 & 1 & ? & $?$ & 0 & 0 & 0 & $?$ & $?$ & 2 & 0 & 1 & 2 & 0 & 1 & 0 & 0 & 0 & 0 & 1 & 0 & 1 & 0 & 1 & 0 & 1 & 1 & 0 \\
\hline Kedros & 0 & 1 & 1 & 0 & 0 & 1 & 0 & 0 & 1 & 0 & 0 & 1 & 0 & 0 & $?$ & $?$ & $?$ & 0 & 1 & 2 & 0 & 1 & 0 & 0 & 0 & 0 & 1 & 0 & [01] & [01] & 1 & & 0 & 1 & 0 \\
\hline Melothria pendula & 0 & 1 & 1 & 0 & 0 & 1 & 0 & [01] & 0 & 1 & 0 & 1 & 0 & 0 & $?$ & 0 & 2 & 0 & 1 & 2 & 0 & 1 & 0 & 1 & 1 & 0 & 1 & 0 & 1 & 0 & 0 & 0 & & 0 & 0 \\
\hline Melothria warmingii & 0 & 1 & 1 & 0 & 0 & 1 & 0 & 0 & 0 & 0 & 0 & 1 & 0 & 0 & ? & 01 & [02] & 0 & 1 & 2 & 1 & 1 & 1 & 0 & 1 & 0 & 1 & 0 & 1 & 1 & 1 & 0 & 1 & 0 & 0 \\
\hline Melothriarthus smilacifolius & 0 & 1 & 1 & & 0 & 1 & 0 & 0 & [01] & 1 & 0 & [01] & 0 & 0 & ? & 0 & 2 & 0 & 1 & 2 & 1 & 1 & 1 & 1 & 1 & 0 & 1 & [01] & 0 & 1 & 1 & & 1 & 1 & 0 \\
\hline Psiguria ra & [01] & 1 & 1 & ? & 0 & 1 & 0 & 1 & 1 & 1 & 0 & [02] & 0 & 0 & ? & ? & 2 & 3 & 0 & 1 & 0 & 1 & 3 & 0 & 0 & 1 & 0 & 1 & 0 & 0 & 1 & 0 & 1 & 0 & 0 \\
\hline Seyrigia h & 0 & 0 & 1 & ? & [01] & 1 & 0 & 0 & 0 & 1 & 0 & 0 & 0 & 0 & ? & ? & & 0 & 0 & 2 & 0 & & 0 & & 1 & 1 & 0 & 0 & 0 & 1 & 1 & & & 0 & 1 \\
\hline Trochomeriopsis diversifolia & 0 & [12] & 1 & 0 & 0 & 0 & 0 & 0 & 1 & 0 & 0 & 0 & 0 & 0 & ? & $?$ & 0 & 0 & 1 & 2 & 0 & 1 & 0 & 0 & 0 & [01] & 0 & [01] & 1 & 1 & 1 & 0 & 1 & 1 & 0 \\
\hline Tumamoca macdougalii & 0 & 1 & 1 & 0 & 0 & 0 & 0 & 1 & 1 & ? & ? & 0 & ? & 0 & 0 & ? & 0 & 0 & 1 & 2 & 0 & 1 & 0 & 0 & 0 & 0 & 1 & 0 & 1 & 1 & ? & 0 & 0 & 1 & 1 \\
\hline & 0 & 1 & 1 & 1 & 0 & 1 & 1 & [01] & 1 & 1 & 0 & 0 & 0 & 0 & 1 & 0 & 2 & 0 & 1 & 1 & 0 & 1 & 1 & 0 & 0 & [01] & 1 & [01] & 1 & 1 & 0 & 0 & 1 & 0 & 2 \\
\hline Wilbrandia verticillata & 0 & 1 & 1 & 1 & 0 & 0 & 1 & 0 & 1 & 1 & 0 & 0 & 0 & 0 & 1 & 0 & 2 & 0 & 1 & 1 & 0 & 1 & 1 & 0 & 0 & 1 & 1 & (01) & 0 & 1 & 1 & & & 0 & 2 \\
\hline
\end{tabular}

1. Vástago: (0) Herbáceo. (1) Leñoso. 2. Hojas: (0) Ausentes. (1) Presentes simples. (2). Presentes compuestas. 3. Zarcillos: (0) Ausentes. (1) Presentes simples. (2) Presentes compuestos. 4. Zarcillos, prefoliación: (0) Recta. (1) Circinada.5. Inflorescencia estaminada, pedúnculo: (0) Desarrollado. (1) Reducido. 6. Inflorescencia estaminada, eje: (0) Alargado. (1) No alargado. 7. Flor estaminada, pedicelo: (0) Desarrollado. (1) Reducido. 8. Flor estaminada, bráctea: (0) Presente. (1) Ausente. 9. Hipanto de la flor estaminada, forma: (0) Acampanado u obcónico. (1) Subcilíndrico-infundibuliforme. (2) Reducido, casi nulo. 10. Hipanto de la flor estaminada, pubescencia interior del ápice: (0) Glabro o glabrescente. (1) Villoso-lanoso. 11. Hipanto de la flor estaminada, pubescencia interior de la zona media: (0) Glabro o glabrescente. (1) Villoso-lanoso. 12. Hipanto de la flor estaminada, pubescencia exterior: (0) Glabro o glabrescente. (1) Con tricomas eglandulares, simples, filiformes, con célula apical aguda. (2) Con tricomas glandulares, simples, capitados, explosivos. (3) Con tricomas eglandulares, simples, filiformes, con célula apical uncinada. 13. Hipanto y cáliz de la flor estaminada, color: (0) Verde. (1) Amarillo. (2) Rojo. 14. Cáliz de la flor estaminada, prefloración: (0) Abierta. (1) Valvar. 15. Corola de la flor estaminada, prefloración: (0) Valvar. (1) Imbricada. 16. Pétalos, vernación y margen: (0) Induplicada. (1) Plana. (2) Circinada. (3) Involuta. 17. Pétalos de la flor estaminada, indumento interno: (0) Glabro o glabescente. (1) Con tricomas eglandulares, uniseriados. (2) Con tricomas glandulares, moriliformes. 18. Pétalos de la flor estaminada, color: (0) Amarillo-Anaranjado. (1) Blanco. (2) Verde. (3) Rosado. 19. Androceo, estructura: (0) 2+2. (1) 2+2+1. (2) $1+1+1+1+1$. 20. Estambres, posición: (0) Base del hipanto. (1) 1/2-1/3 superior del hipanto. (2) Fauce del hipanto. 21. Anteras: (0) Dorsifijas. (1) Basifijas. 22. Tecas: (0) Flexuosas. (1) Rectas o apenas arqueadas. 23. Conectivo, indumento del ápice: (0) Glabro. (1) Con tricomas eglandulares, uniseriados. (2) Con tricomas ampuliformes. (3). Con papilas. 24. Conectivo, indumento del margen: (0) Glabro. (1). Con tricomas eglandulares, pestañosos. 25. Pistilodio: (0) Ausente. (1). Con pistilodio carpelar, emergente. (2) Con pistilodio hipantial, invaginación tubular basal. 26. Inflorescencia carpelada, pedúnculo: (0) Desarrollado. (1) Reducido. 27. Flor carpelada, pedicelo: (0) Desarrollado. (1) Reducido. 28. Cantidad de flores carpeladas por inflorescencia: (0) 1 ó 2. (1) Más de 2 flores. 29. Ovario, número de placentas: (0) 2. (1) 3. (2) 5 (excepcionalmente 4). 30. Estaminodios: (0) Ausentes. (1) Presentes, en igual número que los estambres. (2) Presentes, en mayor número que los estambres. 31. Estigma, lóbulos: (0) Enteros. (1) Lobulados. 32. Fruto: (0) Indehiscente. (1) Dehiscente. 33. Semillas cantidad: (0) Pocas (hasta 12). (1) Muchas (ca. 20 ó más). 34. Semilla, compresión: (0) Comprimidas en el plano sagital. (1) No comprimidas. 35. Semilla, superficie del tegumento: (0) Lisa. (1) Escrobiculada. (2) Irregular, como envuelta en una capa densa que se torna esponjosa al humedecerse. 


\section{Análisis filogenéticos}

Se analizaron 3 matrices: a) una matriz molecular ( $r b c L+$ trnL-F) de 37 taxones $\times 2175$ caracteres, de los cuales sólo 64 resultaron informativos; b) una matriz morfologica de 45 taxones x 35 caracteres (Tabla 2), de los cuales 32 resultaron informativos; $c$ ) y una matriz de evidencia total de 45 taxones $\times 2210$ caracteres, con 97 caracteres informativos.

El análisis de la matriz molecular dio como resultado más de 10000 árboles de 134 pasos, el árbol de consenso estricto se muestra en la Figura 17. El análisis de la matriz morfológica dio como resultado 11 árboles de 142 pasos, el árbol de consenso estricto se muestra en la Figura 18. Finalmente, el el análisis de la matriz combinada (molecular + morfología) dio como resultado 24 árboles de 303 pasos, el árbol de consenso estricto se muestra en la Figura 19.

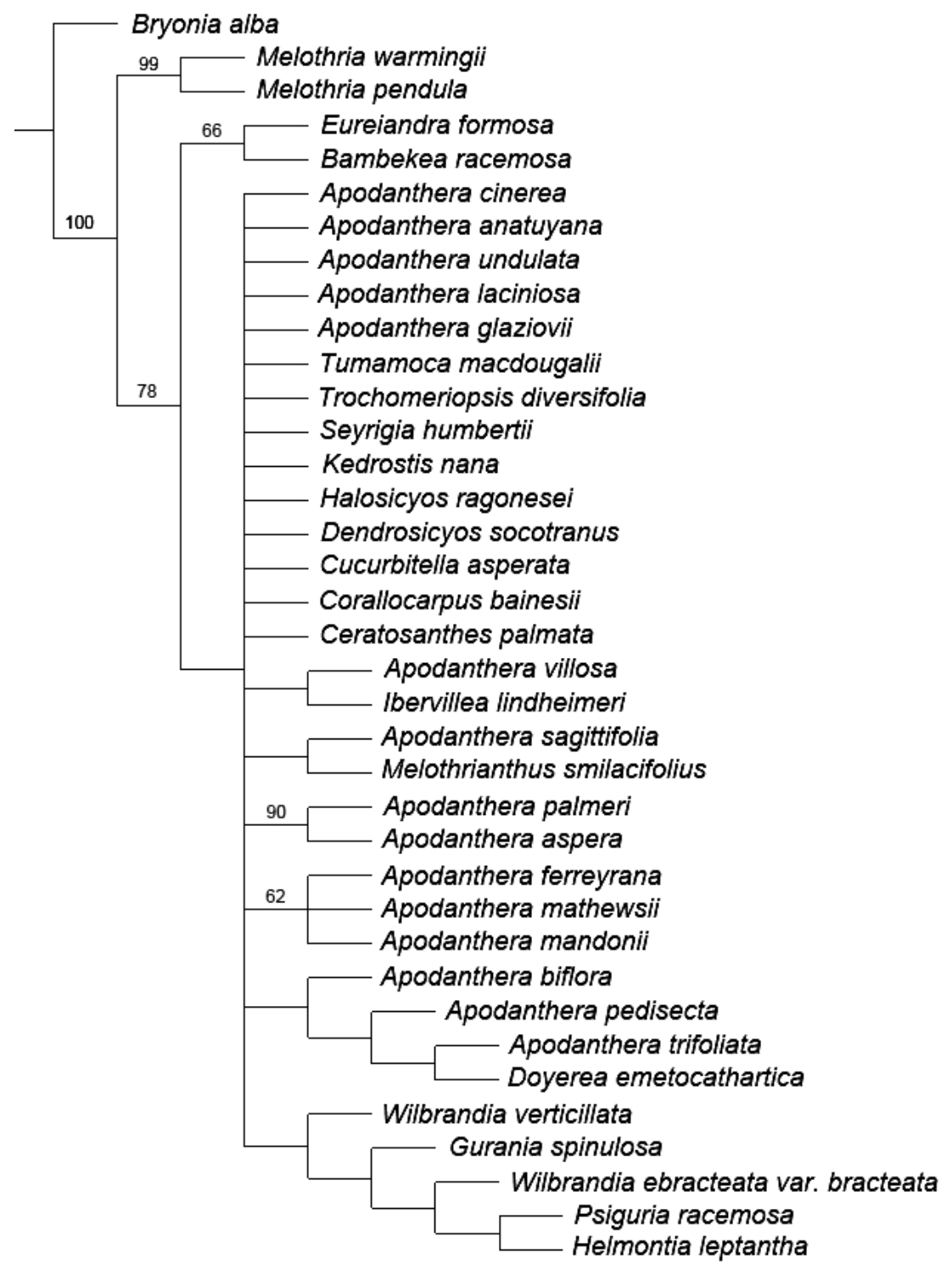

Figura 17. Árbol de consenso estricto obtenido del análisis de la matriz de secuencias nucleotídicas ( $r b c L+\operatorname{trnL}-\mathrm{F}$ ). Se indica el soporte de ramas cuando es superior a 50. 


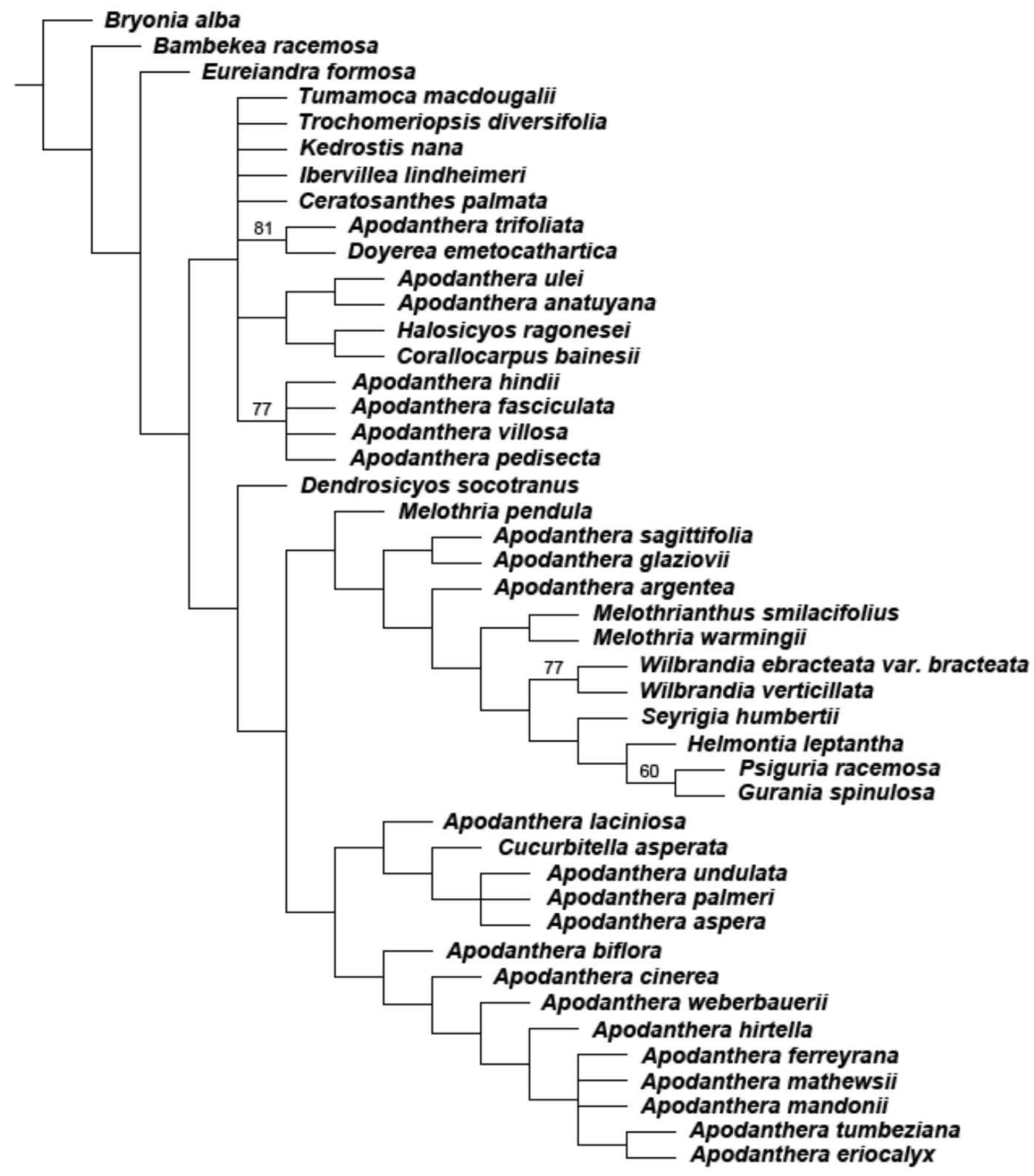

Figura 18. Árbol de consenso estricto obtenido del análisis de la matriz de caracteres morfológicos. Se indica el soporte de ramas cuando es superior a 50. 


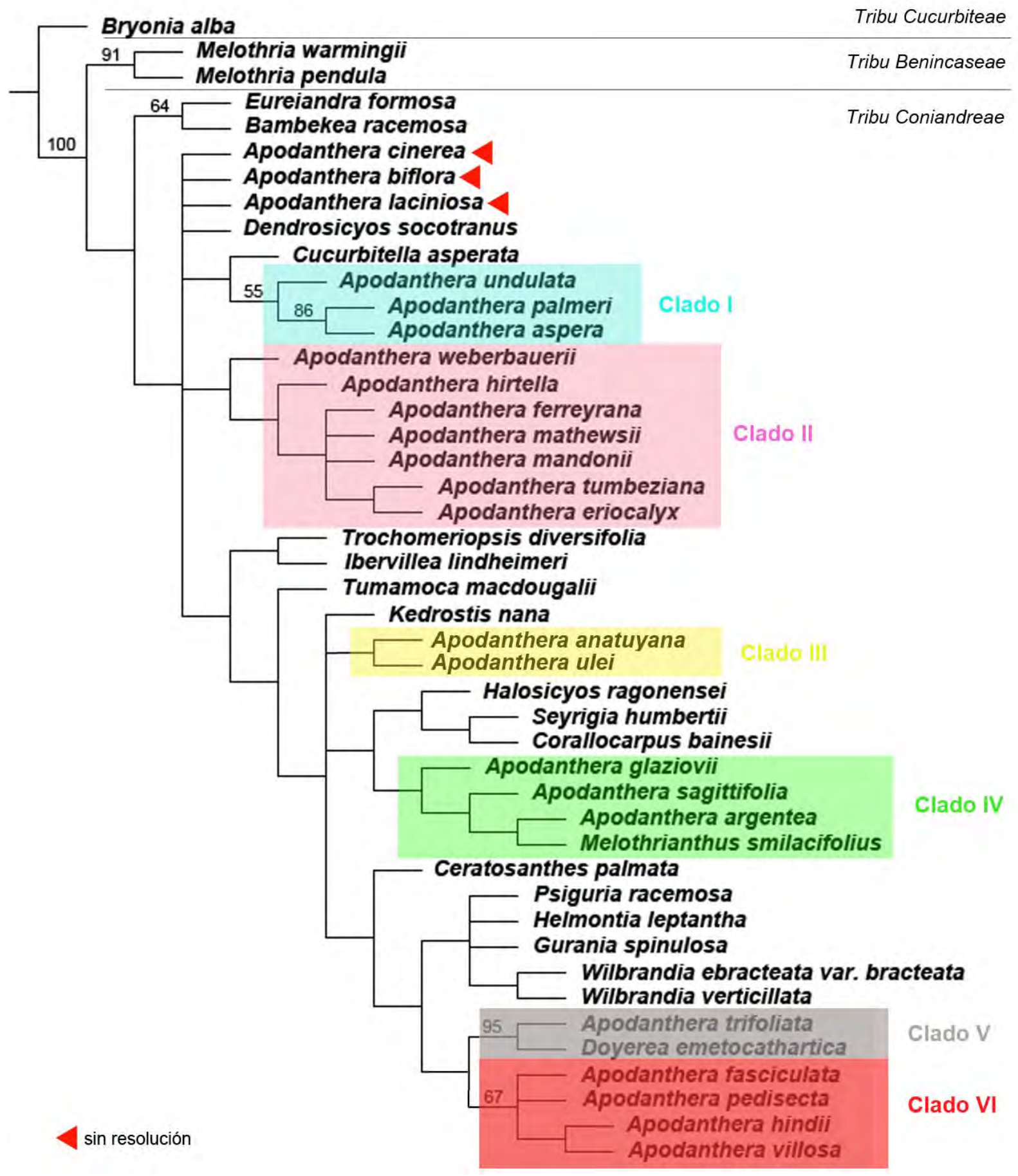

Figura 19. Árbol de consenso estricto obtenido del análisis combinado (evidencia total) de la matriz de caracteres morfológicos + las secuencias nucleotídicas. Se indica el soporte de ramas cuando es superior a 50.

El análisis de la matriz molecular mostró poca resolución y bajos soportes, seguramente como consecuencia de la escasa información que aportan los marcadores utilizados; el porcentaje de caracteres informativos tanto en rbcL como en trnL-F es muy bajo en este grupo de taxones. El análisis de la matriz morfológica, por su lado, mostró mayor variabilidad pero con bajos soportes. 
Se observan diversas incongruencias entre los análisis molecular y morfológico, para mencionar algunas:

a) En la reconstrucción molecular el género Melothria (representante de la tribu Benincaseae) es grupo hermano de la tribu Coniandreae, mientras que en la reconstrucción morfológica resultó polifilético y dentro de la tribu Coniandreae. Melothria warmingii se agrupa con Melothrianthus smilacifolius y Melothria pendula se ubica más basalmente, como grupo hermano de un clado que adicionalmente incluye especies de Apodanthera, Gurania, Helmontia, Psiguria, Seyrigia y Wilbrandia.

b) En la reconstrucción molecular Apodanthera biflora se agrupa con A. pedisecta, A. trifoliata y con el género Doyerea; en la morfológica integra un clado que agrupa a las especies andinas de la sección tipo de Apodanthera.

c) En el análisis molecular la posición de A. glaziovii queda sin resolución, mientras que en el morfológico se agrupa con $A$. sagittifolia (en el molecular esta última especie se agrupa con Melothrianthus smilacifolius).

d) En la reconstrucción molecular las posiciones de Apodanthera cinerea y de A. anatuyana quedan sin resolución, en la morfologíca la primera se agrupa con las especies andinas de la sección Apodanthera; la seguna se agrupa con A. ulei, y conforman el grupo hermano de Halosicyos + Corallocarpus bainesii.

e) Un caso curioso es el de Apodanthera villosa, una especie brasileña de la sección Pseudoapodanthera que, en la reconstrucción molecular se agrupa con Ibervillea, un género norteamericano, mientras que en la morfológica lo hace con las demás especies de la sección Pseudoapodanthera.

Contrariamente, se han observado también algunas congruencias entre ambas reconstrucciones, entre estas se pueden destacar: a) Apodanthera trifoliata + Doyerea emetocathartica; b) Apodanthera aspera + A. palmeri; c) la politomía A. ferreyrana, $A$. mathewsii y A. mandonii.

El análisis combinado de ambas matríces (evidencia total) produjo una hipótesis filogenética de mediana resolución y con agrupamientos que en algunos casos son congruentes con la filogenia morfológica y en otros no. En este análisis se hace evidente la polifilia del género Apodanthera, por cuanto la mayoría de sus especies integran grupos distintos, que no comparten ancestros en común (nombrados como Clados I al VI), mientras que las posiciones de otras de sus especies resultaron sin resolución.

El Clado I (3 especies) incluye a las especies de Apodanthera sección Cucurbitopsis, de América del Norte, este clado es grupo hermano del género Cucurbitella. 
El Clado II (7 especies) contiene a la especie tipo del género Apodanthera ( $A$. mathewsii) y a las demás especies andinas de la sección tipo, distribuidas desde el norte de Perú hasta el noroeste de la Argentina.

El Clado III (2 especies) incluye a Apodanthera anatuyana y A. ulei pero sus relaciones con otros grupos no están resultas.

El Clado IV (4 especies) incluye al género monotípico Melothrianthus junto con otras 3 especies brasileñas de la sección tipo de Apodanthera.

El Clado V (2 especies) agrupa a Doyerea (un género monotípico de distribución circuncaribe) con Apodanthera trifoliata con muy alto soporte (el mayor de los resultantes de este análisis).

El Clado VI incluye a las especies de Apodanthera sección Pseudoapodanthera del nordeste de Brasil (a excepción de $A$. trifoliata).

Para algunas especies de Apodanthera (las indicadas con flechas en rojo en la Figura 19) sus posiciones están aún sin resolver (Apodantera cinerea, $A$. biflora y A. laciniosa).

\section{Optimización de caracteres}

Se llevó a cabo la optimización de 32 caracteres morfológicos (3 resultaron no informativos y no fueron considerados: vástago, hojas y lóbulos estigmáticos); las optimizaciones compartidas por los árboles más parsimoniosos se representaron en el árbol de consenso (de evidencia total) para determinar si se trata de caracteres sinapomórficos u homoplásicos.

En la mayoría de los casos, los caracteres morfológicos resultaron ser muy homoplásicos y poco informativos. Kocyan (2007) hace mención a lo dificil que es deducir las relaciones entre las Cucurbitaceae a partir de la morfología, lo cual queda ejemplificado por la gran cantidad de géneros monotípicos en esta familia (según Schaefer \& Renner 2011b, la familia cuenta con 97 géneros, de los cuales 30 son monotípicos, ca. el 30\% de la familia). En este contexto, la inclusión de información molecular para inferir filogenias resulta de gran utilidad.

A continuación se muestran algunas optimizaciones de caracteres morfológicos para ilustrar la homoplasia observada. A drede se han seleccionado los caracteres " $n^{\circ}$ de placentas" (Figura 20), la presencia/ausencia de "estaminodios" (Figura 21) y la "compresión de las semillas" (Figura 22), entre otros, por cuanto han sido utilizados tradicionalmente para distinguir entre géneros. Otro caracter de inportancia que involucra a la flor carpelada es la presencia/ausencia de "pistilodio" (Figura 23) y de qué tipo; lo que ha resultado más frecuente en el análisis es la ausencia de pistilodio, mientras que el de tipo hipantial es una autapomorfía de Apodanthera cinerea y el de tipo carpelar emergente se observa tanto en el clado (Apodanthera glaziovii $+A$. sagittifolia + A. argentea + Melothrianthus) como en Melothria, Seyrigia y Helmontia. 


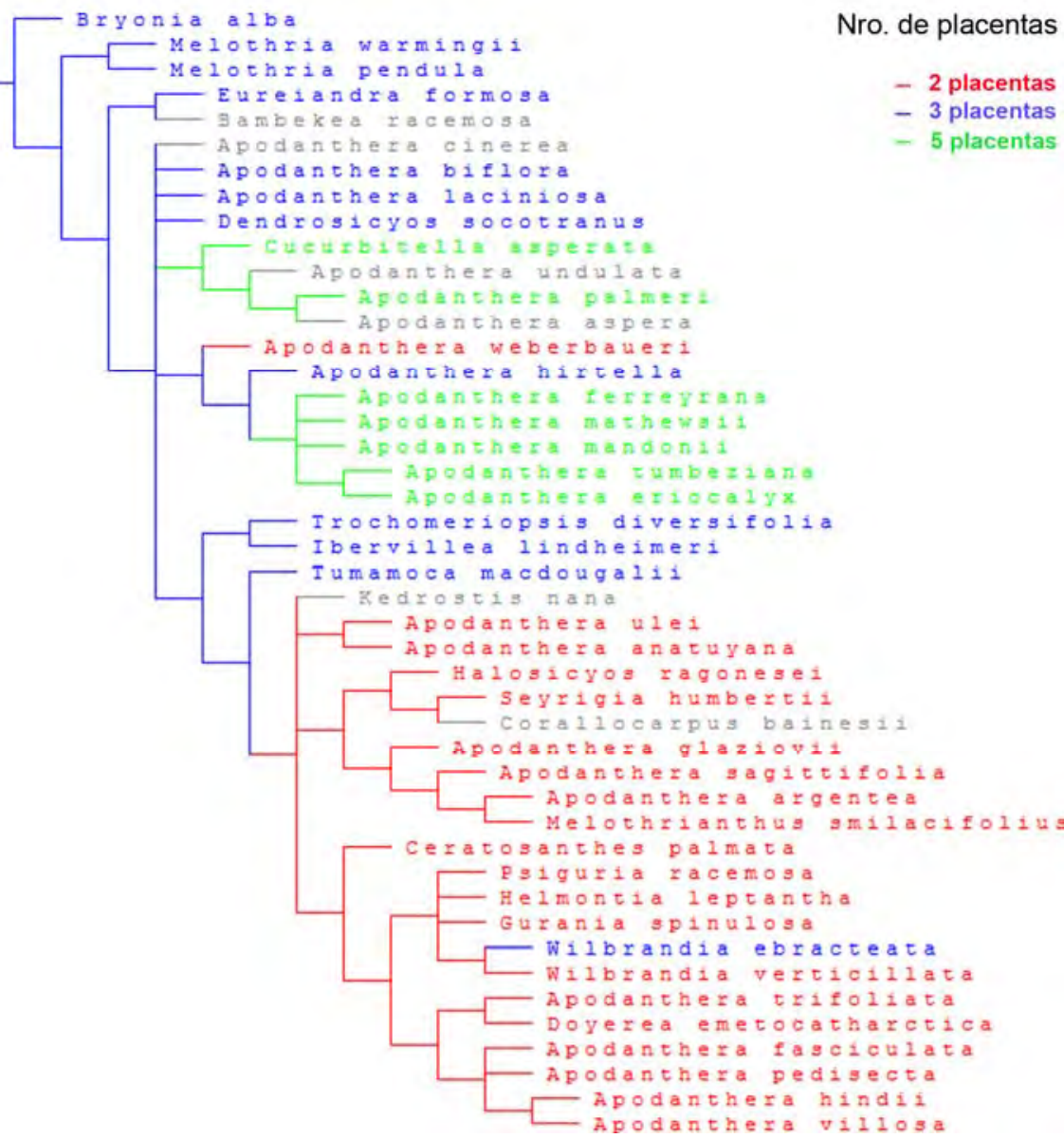

Figura 20

Estaminodios

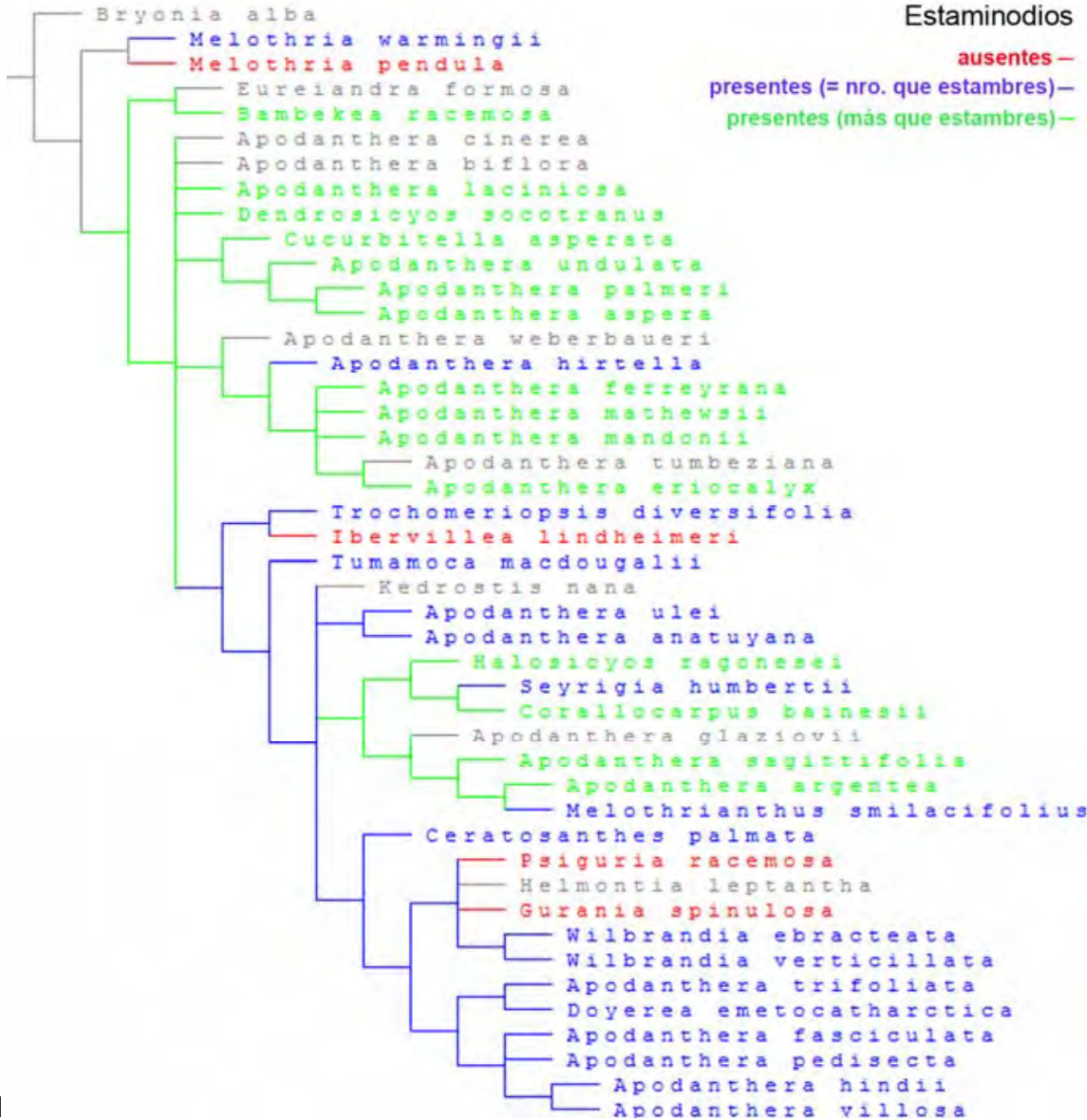




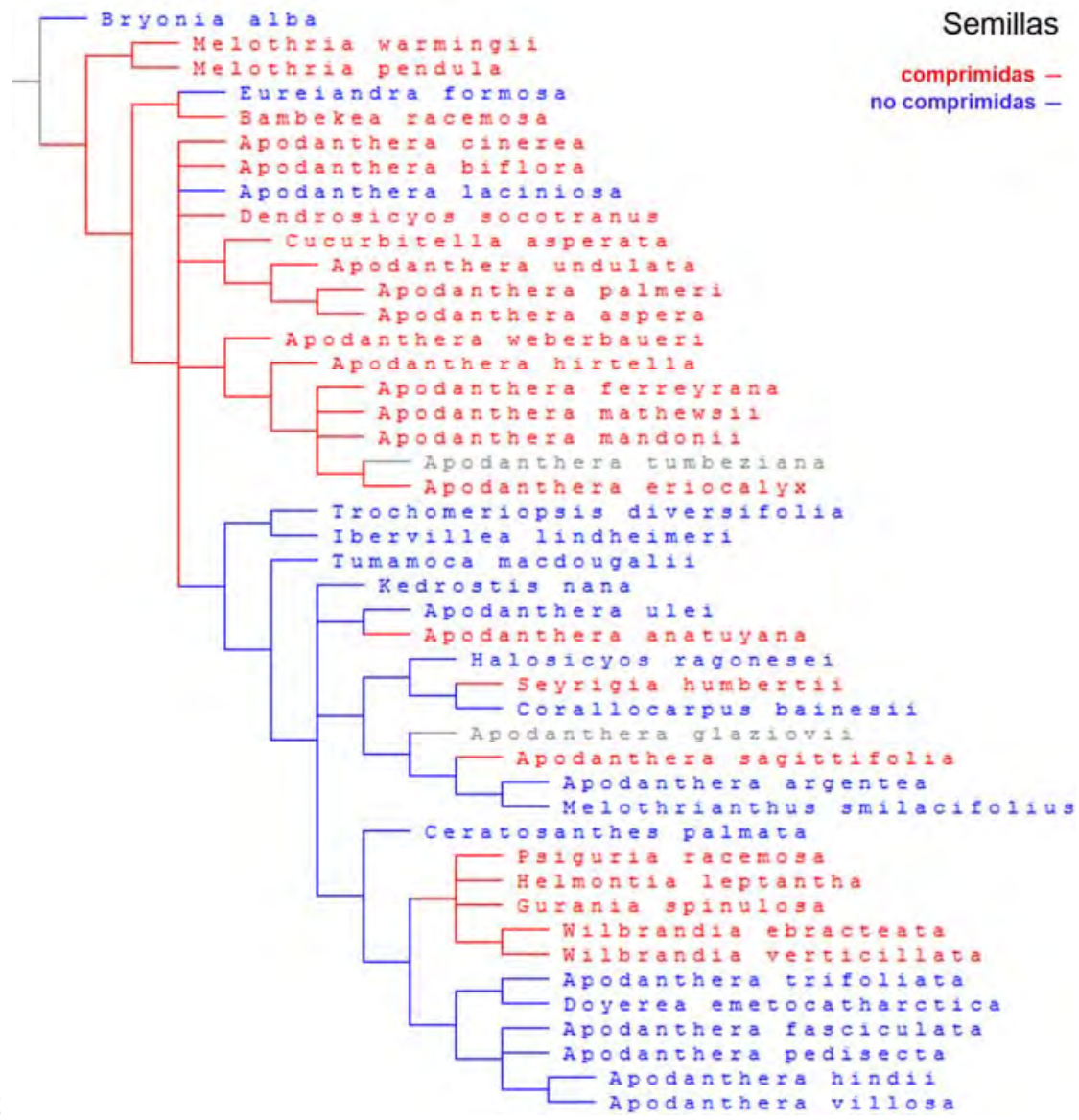

Figura 22

Pistilodio

ausentes presente, carpelar presente, hipantial -

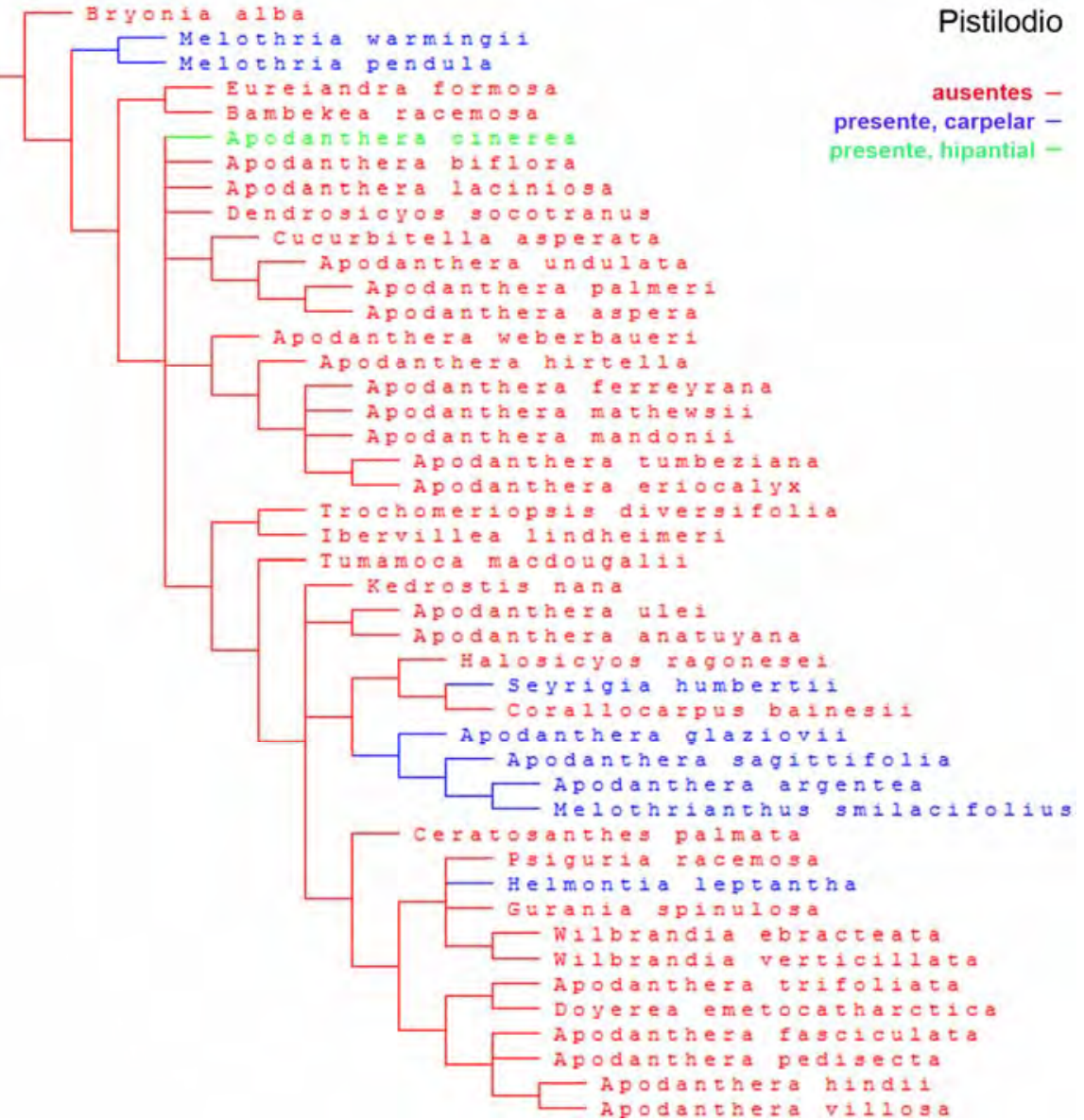


Contrariamente, se muestran algunas optimizaciones que brindan soporte a algunos grupos. Por ejemplo, en la Figura 24 se muestra la optimización del caracter "color del hipanto y el cáliz", donde se observa que el color amarillo es una sinapomorfía del clado (Apodanthera fasciculata $+A$. hindii $+A$. pedisecta $+A$. villosa), mientras que el rojo es una autapomorfía de Gurania. Para el caracter "prefloración del cáliz" (Figura 25) se observa que la prefloración valvar es una sinapomorfía del clado (Apodanthera trifoliata + Doyerea).

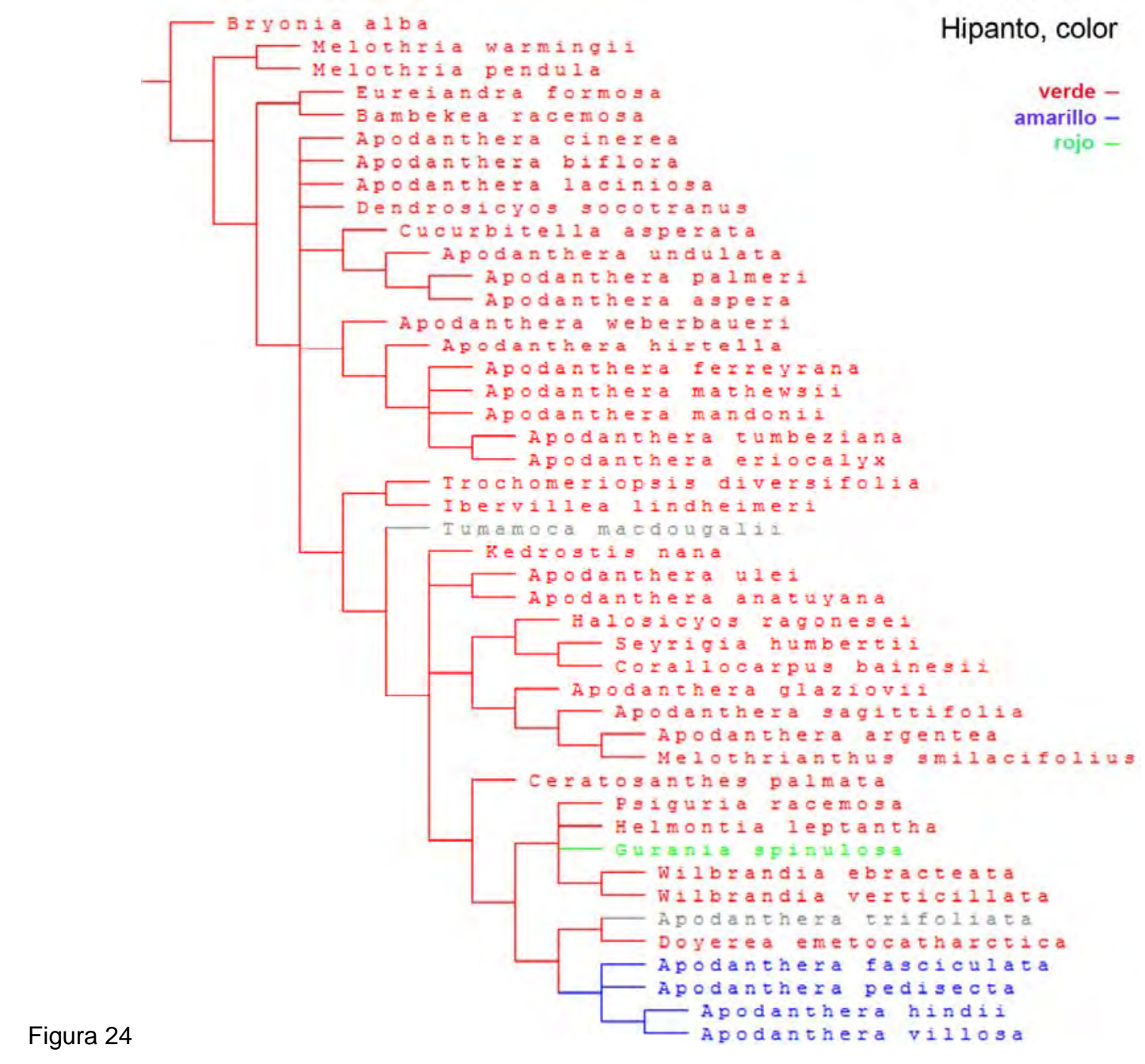




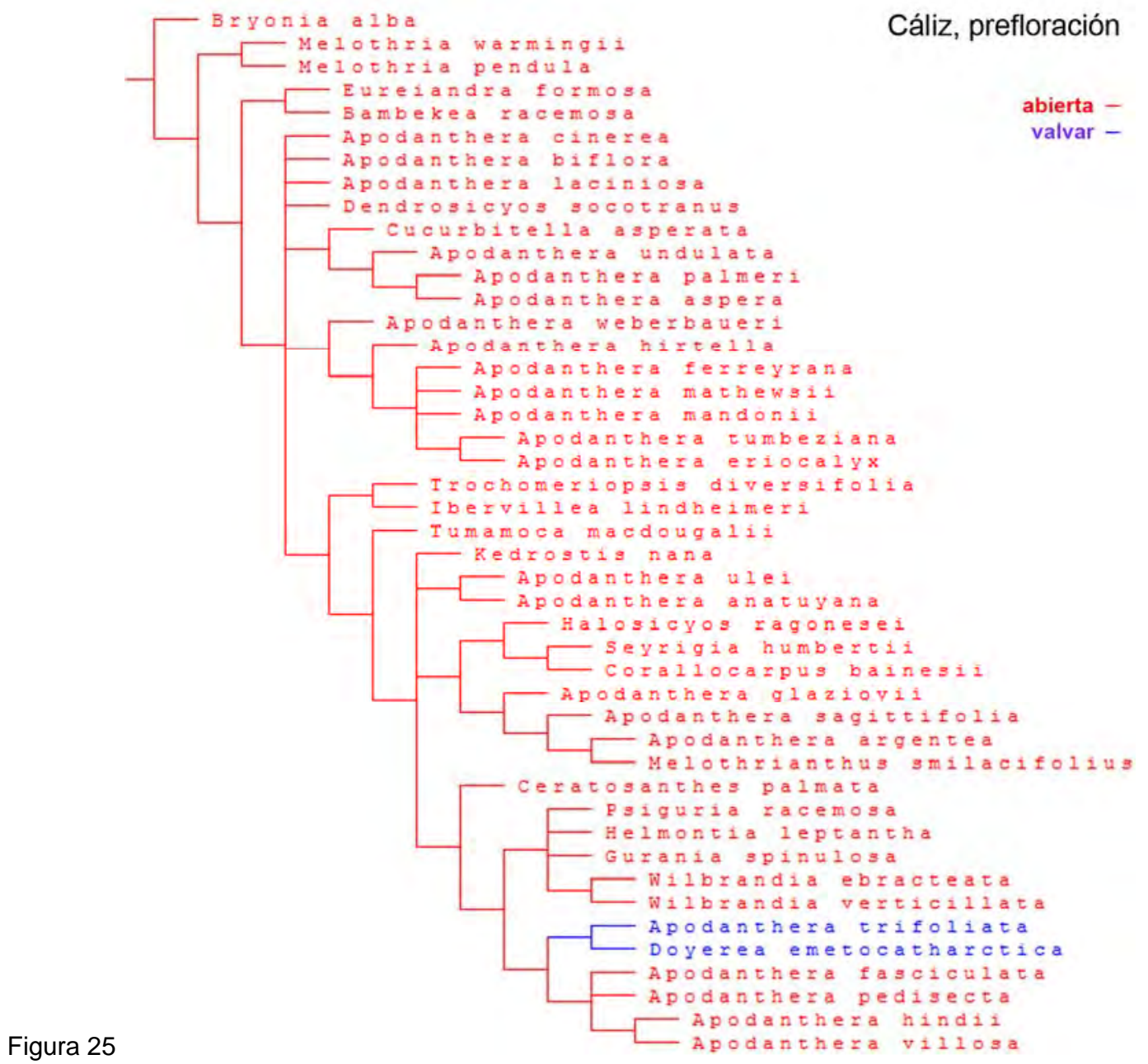

Por último, es necesario mencionar que, a pesar de que los caracteres morfológicos resultaron mayormente homoplásicos, muchos de ellos son útiles para reconocer la gran variabilidad dentro de Apodanthera, para entender su polifilia y para redefinir sus límites frente a los demás géneros de Coniandreae. Entre estos caracteres se pueden mencionar: la presencia/ausencia de pistilodio (en caso de estar presente, de qué tipo); la pubescencia interna del hipanto, el tipo de zarcillo (simple o compuesto), el número de flores carpeladas en la inflorescencia y la cantidad de semillas que maduran en cada fruto. Para más detalle véanse los resultados enunciados en el Tratamiento taxonómico y las claves dicotómicas que allí se proveen. 


\section{Tratamiento taxonómico}

La combinación y síntesis de los resultados obtenidos de los estudios morfológicos y filogenéticos llevados a cabo para esta tesis (Capítulos 2 y 3 respectivamente) permitieron esclarecer los límites de las especies de Apodanthera, redefinir sus límites genéricos y los de sus géneros más afines dentro de la tribu Coniandreae.

En concordancia con lo que se esperaba al comienzo de este trabajo, el número de binomios fundados en Apodanthera excede significativamente (lo duplica) a las morfoespecies. En esta tesis sólo se reconocen como independientes a 23 taxones, todos en el nivel de especie; los restantes nombres fueron colocados en sinonimia. Entre las principales causas de esta situación de sobre abundancia de nombres, se encuentran la gran variabilidad de la lámina foliar, la cantidad de flores en la inflorescencia estaminada y la densidad del indumento de las flores de ambos tipos. Todas estas características son discutidas en detalle en el Capítulo 2 y permiten explicar muchas de las sinonimias aquí propuestas.

De las 23 especies aceptadas como independientes sólo siete de ellas, las de filiación andina, distribuidas desde el norte de Perú hasta el noroeste de la Argentina, se reconocen dentro de Apodanthera. Las secciones Cucurbitopsis (con tres especies de América del Norte) y Pseudoapodanthera (con 4 especies del nordeste de Brasil) fueron escindidas de Apodanthera y consideradas como géneros independientes. Las restantes especies fueron transferidas a otros géneros dentro de la tribu Coniandreae, todos estos considerados como monoespecíficos antes de esta tesis. Apodanthera trifoliata, de la sección Pseudoapodanthera, fue transferida al género Doyerea Grosourdy (1864), que hasta el presente sólo estaba representado por $D$. emetocathartica Grosourdy, de distribución circuncaribe. Otras tres especies (Apodanthera argentea, A. glaziovii y $A$. sagittifolia) de áreas tropicales a templadas de América del Sur fueron transferidas a Melothrianthus Mart.Crov. (1954c). Finalmente, cinco especies (A. anatuyana, $A$. biflora, $A$. cinerea, $A$. laciniosa y $A$. ulei) son consideradas como de posición genérica incierta, por cuanto no se ajustan adecuadamente a ninguno de los géneros estudiados según las observaciones de esta tesis; son tratadas aquí bajo "Incerta saedis".

A continuación se brindan dos claves dicotómicas: una para distinguir los cinco géneros en los que se ha fragmentado Apodanthera en esta tesis; la otra para reconocer no sólo la nueva circunscripción de estos cinco géneros sino también las especies de Apodanthera de ubicación incierta o dudosa. 


\section{Clave de los géneros tratados}

1. Inflorescencias carpeladas fasciuliformes o subespiciformes con eje muy breve, carnoso y grueso, blanco-lanoso; flores carpeladas sésiles o subsésiles; frutos pauciseminados (hasta 12 semillas); semillas piriformes

1'. Inflorescencias carpeladas 1-floras (raramente 2-floras); flores carpeladas pediceladas; frutos multiseminados (más de 20 semillas); semillas ovoides o anchamente elipsoides, poco 0 notablemente comprimidas

2(1). Cáliz con prefloración valvar, ocráceo o amarillo-verdoso; hipanto de la flor estaminada cortamente acampanado u obcónico, de 1,5-2 x 2-2,5 mm, verdoso, interiormente villoso cerca de la fauce, sin nectario mesenquemático basal; pétalos cortamente pilosos en la cara interna; hipanto de la flor carpelada muy breve, subanular, ca. $1 \mathrm{~mm}$ de largo; fruto con ápice truncado

Doyerea

2'. Cáliz con prefloración abierta, amarillo; hipanto de la flor estaminada subcilíndricoinfundibuliforme, de 5-9 x 1,8-4 mm, amarillo, interiormente villoso a media altura, por debajo de los estambres, con un nectario mesenquemático craso, disciforme, en la base; pétalos glabros en la cara interna; hipanto de la flor carpelada subcilíndrico-infundibuliforme a tubular, de 3-9 mm de largo; fruto enangostándose hacia el ápice, algo apiculado

Pseudoapodanthera

3(1'). Ovario 2-placentífero; flores estaminadas con pistilodio carpelar, emergente desde la base, glanduliforme, hemiesférico o subcónico; zarcillos simples

Melothrianthus

3'. Ovario (2-)3-5-placentífero; flores estaminadas sin pistilodio emergente desde la base; zarcillos usualmente compuestos, 2(-3)-fidos

4

4(3'). Flores vistosas, con pétalos (de las flores estaminadas y carpeladas) iguales o de mayor longitud que el hipanto; hipanto villoso-lanoso en su interior; portazarcillos muy breves, hasta de $5 \mathrm{~mm}$ de largo; láminas foliares de contorno suborbicular-reniforme y consistencia subcrasa; raíces masivas, tuberosas y muy engorsadas, con ramificación bifurcada y opuesta. América del Norte, zonas áridas del sur de Estados Unidos y México

Cucurbitopsis

4'. Flores poco vistosas, con pétalos (de las flores estaminadas y carpeladas) de menor longitud que el hipanto; hipanto completamente glabro interiormente; portazarcillos notables, de 3-6(-8) cm de largo; láminas foliares de contorno anchamente elíptico-subpentagonal y de consistencia membranácea; raíces pivontantes engrosadas y tuberosas, sin ramificaciones. América del Sur, Andes de Perú, Bolivia y noroeste de la Argentina

Apodanthera 
Clave de los géneros y de las especies de posición dudosa (incerta saedis) tratados 1. Flores estaminadas con hipanto obcónico, prolongado en la base en una invaginación delgada, tubular (pistilodio hipantial), hasta de $3 \mathrm{~mm}$ de largo y de ancho similar al pedicelo

Apodanthera cinerea

1'. Flores estaminadas con hipanto subcilíndrico-infundibuliforme o acampanado, redoneado en la base o algo atenuado pero nunca prolongado en una invaginación tubular

2(1'). Inflorescencias carpeladas fasciculiformes o cortamente espiciformes, (2-)5-30-floras; flores carpeladas subsésiles; semillas piriformes

2'. Inflorescencias carpeladas 1-floras (raramente 2-floras); flores carpeladas notablemente pediceladas; semillas ovoides a ampliamente elipsoides

3(2). Cáliz con prefloración valvar, ocráceo o amarillo-verdoso; hipanto de la flor estaminada cortamente acampanado u obcónico, de 1,5-2 x 2-2,5 mm, verdoso, interiormente villoso cerca de la fauce, sin nectario mesenquemático basal; pétalos cortamente pilosos en la cara interna; hipanto de la flor carpelada muy breve, subanular, ca. $1 \mathrm{~mm}$ de largo; fruto con ápice truncado

Doyerea

3'. Cáliz con prefloración abierta, amarillo; hipanto de la flor estaminada subcilíndricoinfundibuliforme, de 5-9 x 1,8-4 mm, amarillo, interiormente villoso a media altura, por debajo de los estambres, con un nectario mesenquemático craso, disciforme, en la base; pétalos glabros en la cara interna; hipanto de la flor carpelada subcilíndrico-infundibuliforme a tubular, de 3-9 mm de largo; fruto enangostándose hacia el ápice, algo apiculado

Pseudoapodanthera

4(2'). Hipanto de las flores estaminadas y carpeladas glabro interiormente

4'. Hipanto de las flores estaminadas y carpeladas villosos o villoso-lanosos interiormente, en la porción superior o en la fauce

5(4). Frutos elipsoides, redondeados en ápice y base; semillas comprimidas; hojas 3-5-lobadas. Andes de Perú, Bolivia y noroeste de la Argentina

Apodanthera s. str. (según los límites establecidos en esta tesis, véase clave en el género) 5'. Frutos oblongoides, apiculados; semillas no comprimidas; hojas profundamente 5-7(-9)lobadas o sectadas (muy raramente hojas acorazonadas). Sudeste de Brasil y extremo nordeste de la Argentina (Misiones)

Apodanthera laciniosa

6(4'). Ovario 3-5-placentífero 


\section{6'. Ovario 2-placentífero}

7(6). Láminas foliares de contorno suborbicular-reniforme, de borde entero a profundamente lobado, subcrasas; ovario usualmente 5-placentífero (más raramente 3-placentífero); estigmas 2-lobulados en forma de "U"; zarcillos compuestos; frutos ca. $10 \mathrm{~cm}$ de largo; raíces masivas de gran desarrollo, bifurcadas transversalmente; tallos perennes numerosos. América del Norte, sur de los Estados Unidos de América al centro-sur de México

Cucurbitopsis

7'. Hojas de contorno acorazonado, enteras o más raramente lobadas, membranáceas; ovario 3-placentífero; estigmas 2-lobulados con lóbulos oblongoides; zarcillos simples; raíces tuberosas, napiformes, no bifurcadas; tallos perennes usualmente uno. América del Sur, zona costera de Ecuador y Perú

Apodanthera biflora 8(6'). Flores estaminadas con pistilodio carpelar emergente en la base interior del hipanto (glandular, hemisférico o subcónico); frutos multiseminados (10 semillas o más); láminas foliares de contorno acorazonado, lanceolado, oblongo-lanceolado, subtriangular o sagitado, enteras a profundamente sectadas

Melothrianthus

8'. Flores estaminadas sin pistilodio carpelar emergente en la base interior del hipanto; frutos pauciseminados (hasta 8 semillas); láminas foliares de contorno suborbicular a subpentagonal, profundamente lobadas a sectadas

9(8'). Inflorescencias estaminadas y carpeladas a menudo co-axilares; flores estaminadas bracteadas; semillas comprimidas de superficie irregular y esponjosa cuando húmeda; zarcillos simples. Chaco del sur de Bolivia y norte de la Argentina

Apodanthera anatuyana

9'. Inflorescencias estaminadas y carpeladas en nudos diferentes; flores estaminadas ebracteadas; semillas no comprimidas de superficie lisa; zarcillos compuestos. Sudeste de Brasil

Apodanthera ulei 
Apodanthera Arn., J. Bot. (Hooker) 3(21): 274. 1841. ESPECIE TIPO. Apodanthera mathewsii Arn.

Hierbas perennes, diclino-monoicas o dioicas, zarcillosas (trepadoras o rastreras); raíz tuberosa; tallo perenne usualmente uno, subterráneo, breve, del que crecen tallos anuales herbáceos, que se extienden hasta varios metros, estriados longitudinalmente, ligeramente angulados, glabrescentes, híspidos o hirsutos (más densamente en las partes jóvenes, esparcidamente en las adultas), con tricomas blancuzcos, eglandulares uniseriados, filiformes o cónicos de base unicelular. Hojas de filotaxis espiralada, sin estípulas, pecioladas; pecíolos algo robustos y aplanados, usualmente hírtulos, hirsutos o hirsuto-tomentosos; láminas anchamente ovadas, subpentagonales, enteras, poco o notoriamente 3-5(-7)-lobadas o 3-5sectadas, membranáceas, a menudo discolores (raramente concolores), con base amplia y profundamente cordada y ápice agudo u obtuso, mucronado o acuminado; lóbulos, cuando presentes, ovados, oblongos o lanceolados, de ápice redondeado a triangularmente obtuso, con senos redondeados, margen subentero a dentado en distinto grado de profundidad, remotamente denticulados, con dentículos glandulares (hidátodos), triangulares; el indumento de la lámina está conformado por tricomas eglandulares uniseriados, cónicos, de base uniceluar o multicelular, robustos, con célula apical subulada, adpresos, a menudo más densamente en la cara abaxial, sobre los nervios los tricomas se disponen más profusamente, raramente las láminas son glabrescentes. Zarcillos 1 por nudo, usualmente compuestos, 2(-3)fidos, raro simples, rectos en la yema, luego enroscándose (por encima del punto de bifurcación), finamente estriados, gabrescentes o con algunos tricomas dispersos, portazarcillos más o menos rectos, bien diferenciados. Flores diclinas, pentámeras (excepcionalmente la corola puede ser 4 ó 6 lobulada), actinomorfas, los sépalos tienen prefloración abierta, la corola imbricada. Inflorescencia estaminada inicialmente de aspecto fasciculiforme o subumbeliforme, a menudo adquiere luego un aspecto racemiforme a medida que se desarrolla el eje entre las flores, pedunculada, usualmente 1 inflorescencia (raramente 2) por nudo; pedúnculo erecto o ascendente, estriado longitudinalmente, con tricomas uniseriados, eglandulares o glandulares, algo patentes, esparcidos; pedicelos persistentes, híspidos, hirsutos o hirsuto-tomentosos, con tricomas uniseriados, eglandulares cónicos, con base unicelular o glandulares capitados simples (explosivos). Flores estaminadas ebracteadas (raramente con una bráctea filiforme en la base del pedicelo); hipanto subcilíndrico o cilíndricoinfundibuliforme, ensanchándose hacia la garganta, la base es a menudo redondeada y más ancha que la porción media, debido a la presencia de un nectario mesenquemático craso y lúteo en su interior, externamente el hipanto puede ser glabrescente, hispídulo (con tricomas cónicos de base unicelular) poco o densamente hirsuto (con tricomas glandulares capitados, simples) o lanoso (con tricomas eglandulares filiformes, entrelazados), interiormente el hipanto es completamente glabro; sépalos triangulares, cortamente lanceolados o cortamente 
ensiformes, a veces algo recurvos, con indumento similar al del hipanto; pétalos de vernación induplicada, libres hasta la base, enteros o más raramente 2 lobulados, obovados, anchamente elípticos o suborbiculares, con ápice redondeado o truncado, a veces mucronulado, con el margen entero a finamente crenado, de color amarillo o amarillo-anaranjado, con 3-5(-7-9) nervios más notables, la cara dorsal es a menduo afelpado-pubescente, con tricomas uniseriados, simples o ramificados, cortos, la cara ventral es punteado-glandular, con abundantes tricomas moruliformes, con cabezuelas pluricelulares y pedículo breve; estambres 3, frecuentemente alternipétalos, 2 ditécicos y 1 monotécico, insertados en el tercio superior del hipanto, resultando el ápice de los mismos exerto o completamente insertos; anteras dorsifijas, elipsoides u oblongo-elipsoides; filamento brevísimo, glabro; conectivo angosto, hialino, no extendido en el ápice, glabro o más raramente con tricomas glandulares ampuliformes en el ápice; tecas alantoides o botuliformes, rectas o apenas arqueadas, a veces curvadas en el ápice y/o la base, de dehiscencia longitudinal; pistilodio ausente. Inflorescencia carpelada 1flora (raro 2-flora), cuando en un mismo tallo crecen inflorescencias estaminadas y carpeladas, lo hacen en nudos diferentes, excepcionalmente son co-axilares; pedicelos finamente estriados, alargándose notablemente en el fruto, glabros, esparcidamente pilosos, hírtulos o hispídulos, con tricomas uniseriados eglandulares (cónicos de base unicelular) o glandulares (capitados simples), patentes. Flor carpelada ebracteada; hipanto cilíndrico, glabro interiormente, hírtulo, hispídulo o lanoso exteriormente, con indumento variado (tricomas eglandulares cónicos de base unicelular o largamente filiformes o glandulares capitados); sépalos lanceolados a subulados, con indumento similar al del hipanto; corola similar a la de las flores estaminadas, estaminodios 3(-4)-5, alternipétalos o en posiciones intermedias (cuando 5 a menudo aproximados entre sí de a pares, quedando uno desapareado), diminutos, desiguales, de formas diversas (mamiliformes, dentiformes, triangulares, setiformes, subulados) insertados cerca de la garganta del hipanto, a la altura en que se dividen las piezas de la corola; ovario ínfero, elipsoide, ovado-elipsoide o más raramente oblongoide o fusiforme, usualmente truncado en la base, 2-3 ó 5-carpelar, 2-3 ó 5-placentífero, exteriormente glabrescente, hispídulo, hirsuto o hírtulo, con tricomas uniseriados eglandulares filiformes o cónicos o glandulares capitados, simples; estilo columnar, glabro, con 2-3 ó 5 ramas más o menos diferenciadas; estigmas 2-lobulados, con lóbulos oblongoides o en forma de "U", de superficie papilosa; óvulos anátropos, numerosos, horizontales. Fruto una baya multiseminada, carnosa, indehiscente, elipsoide o subglobosa, con la base redondeada o truncada y el ápice redeondeado o ligeramente apiculado, rostrado, de superficie lisa, hírtulo o glabrescente cuando maduro. Semillas ovado-elipsoides, comprimidas, lisas, de color castaño claro u oscuro, sin un reborde manifiesto en el plano medio sagital, sólo con una banda de coloración blanco cremoso; saco ariloide hialino. 
Según esta tesis, el género Apodanthera en sentido estricto cuenta con 7 especies, todas ellas muy similares en su morfología, distribuidas principalmente en los Andes de Perú, Bolivia y hacia el sur hasta el noroeste de la Argentina. Sus especies crecen en laderas expuestas y secas, rocosas, en suelos poco profundos, pedregosos, usualmente entre 1800 y $3500 \mathrm{~m} \mathrm{s.} \mathrm{m.,}$ aunque en los cerros del norte de Perú lo hacen entre los 400 y los 900 m s.m. Ocupan el bosque seco tropical en el noroeste de Perú y la serranía esteparia de los Andes centrales de Perú, Bolivia y noroeste de la Argentina.

Etimología. El nombre genérico Apodanthera deriva de los vocablos griegos "a" = sin, "podus" = pie y "antheros" = antera, en alución a los estambres con filamentos brevísimos y anteras casi sésiles.

Observación. Schaefer \& Renner (2011a) colocaron al género monotípico Guraniopsis Cogn. en sinonimia de Apodanthera, propuesta que no pudo ser contrastada durante esta tesis (véase más adelante en este capítulo la discusión de este punto en “Taxón dudoso”).

\section{Clave de las especies de Apodanthera en sentido estricto}

1. Ovario 2-placentífero; estilo con 2 ramas; hipanto de la flor estaminada notablemente ensanchado en el tercio superior, donde se alojan los estambres; pétalos 2-lobulados; conectivo con tricomas glandulares ampuliformes en el ápice; inflorescencia estaminada con aspecto de umbela pedunculada; zarcillos simples

A. weberbauerii

1'. Ovario 3-5-placentífero; estilo con 3-5-ramas; hipanto de la flor estaminada algo ensanchado en el ápice, estambres parcialmente exertos; pétalos enteros; conectivo glabro; inflorescencia estaminada con aspecto de racimo pedunculado; zarcillos usualmente compuestos

2(1'). Láminas tenuemente membranáceas, concolores, glabrescentes en ambas caras, con margen uniformemente dentado-crenado; estilo con 5 ramas profundamente divididas, de longitud desigual

A. tumbeziana

2'. Láminas membranáceas, poco a marcadamente discolores, hírtulas o hispídulas en la cara adaxial, pilosas a tenue o profusamente tomentosas en la abaxial, con margen subentero, toscamente dentado o sinuado; estilo columnar, obscuramente dividio en 3-5 ramas muy breves

3(2'). Láminas palmatilobadas, los lóbulos de margen notablemente dentado; ovario 3placentífero; estilo con 3 ramas; lóbulos estigmáticos oblongoides

A. hirtella 
3'. Láminas subenteras o ligera a profundamente 3-5-lobadas o 3-5-sectadas, los lóbulos de margen subentero o algo sinuado, denticulado; ovario (3)5-placentífero; estilos usualmente con 5 ramas (raro 3); lóbulos estigmáticos en forma de "U"

4(3'). Pedicelo e hipanto de las flores estaminadas y carpeladas completamente lanosos exteriormente, con tricomas eglandulares uniseriados, filiformes, adpreso-ascendentes, entrelazados

A. eriocalyx

4'. Pedicelo e hipanto de la flores estaminadas y carpeladas escasa a densamente hirsutos exteriormente, con tricomas glandulares capitados, secretores, robustos, patentes o algo arqueados (raramente el hipanto puede ser glabrescente pero el pedicelo siempre hirsuto)

5(4'). Láminas profundamente 3-5-lobadas o 3-5-sectadas, los lóbulos o sectos con el margen sinuoso o irregularmente lobulado, notablemente discolores, cara abaxial bronceadotomentosa; pedicelo e hipanto de la flor estaminada densamente hirsutos, en su totalidad

A. mandonii

5'. Láminas subenteras o 3-5-lobadas, lóbulos de margen subentero o irregularmente dentado, discolores, cara abaxial blanco-tomentosa; pedicelo e hipanto de la flor estaminada esparcidamene hirsutos, a menudo sólo abundantemente hacia la base, algunas veces el hipanto puede ser glabrescente

6(5'). Frutos elipsoides, de 4,5-10 x 2,2-6 cm; pétalos de la flor estaminada de 4-4,5 x 4-5 mm de largo, a veces con un mechón de tricomas tiesos sobre el nervio medio en la cara externa; cara abaxial de la lámina profusamente tomentosa

A. mathewsii

6'. Frutos subglobosos, ca. 2,4 x 2,2 cm; pétalos de la flor estaminada ca. 8 × 5,5 mm de largo, sin un mechón de tricomas tiesos sobre el nervio medio en la cara externa; cara abaxial de la lámina tenuemente tomentosa

A. ferreyrana

1. Apodanthera eriocalyx Cogn., Bot. Jahrb. Syst. 50(Beibl.111): 75. 1913. "Peru: In montibus prope Station Chosica, 1900-2000 m., "m. Aprili fl. et fr." Weberbauer 5343". TIPO. Perú. Montagne prés de la Station Chosica, 1900-2000 m s.m., 10 Abr 1910, A. Weberbauer 5343 (holotipo, BR-649 322!; isotipos, F-628346!, GH-31803!; foto Serie Field Museum no 8953!). Figura 26. 
Hierbas perennes, diclino-monoicas, zarcillosas; tallos anuales de 1-6 m de largo y 1,5-2,5 mm de diámetro, estriados longitudinalmente, hirsutos; entrenudos de 4,5-10,8 cm de largo. Pecíolos robustos, algo aplanados cerca de la lámina, de 1,2-4,2 cm x 1,5-2,5 mm, estriados longitudinalmente, hirsutos; láminas anchamente ovadas o subpentagonales, profundamente 5lobadas, de 6-12 x 6,6-12,3 cm, membranáceas, base profunda y ampliamente cordada, margen irregularmente sinuado, más raramente subentero, remotamente denticulado (hidátodos), marcadamente discolores, cara adaxial verde, esparcidamente piloso-escabrosa, con tricomas eglandulares cónicos, de base multicelular persistente, cara abaxial densamente tomentosa, cenicienta, con tricomas eglandulares cónicos, de base unicelular, largos y adpresos, lóbulo central ovado a ovado-elíptico, los laterales similares, algo menores, lóbulos de ápice redondeado o subtriangular, obtuso o agudo, respectivamente, mucronulado. Zarcillos compuestos, 2-fidos, raro simples, finamente estriados, escasa a densamente hirsutos, portazarcillos hasta de $3 \mathrm{~cm}$ de largo. Inflorescencia estaminada 3-9-flora, de aspecto subumbeliforme o racemiforme; pedúnculo ascendente, hasta de $10,5 \mathrm{~cm}$ de largo, estriado longitudinalmente, hirsuto, con tricomas patentes; pedicelos de 0,7-2,5 cm de largo en flores abiertas, lanosos. Flores estaminadas ebracteadas; hipanto subcilíndrico o cilíndricoinfundibuliforme, de 0,9-1,4 cm de largo x 3-3,5 mm de ancho en la parte media y 4-5 mm de ancho en la garganta, base redondeada, algo ensanchada, exteriormente es densamente lanoso en toda su superficie, con tricomas eglandulares filiformes, finos y largos, adpresos y ascendentes, entrelazados, interiormente el hipanto es glabro; sépalos cortamente lanceolados o ensiformes, ca. $3 \mathrm{~mm}$ de largo x 1,5 mm de ancho en la base, lanosos exteriormente como el hipanto, glabros interiormente; pétalos obovados a anchamente elípticos, con ápice obtuso o redondeado, margen entero a finamente crenado, de 6,5-7,5 x 5-6 mm, amarillos, con 5 nervios principales, corta y densamente afelpado-tomentosos en la cara dorsal, con abundantes tricomas glandulares moruliformes, en la ventral; filamento muy breve, glabro; conectivo angosto, glabro, tecas ca. $5 \mathrm{~mm}$ de largo, rectas. Inflorescencia carpelada 1-flora; pedicelo pubescente ca. $1 \mathrm{~cm}$ de largo, alargándose en el fruto (hasta $5 \mathrm{~cm}$ ); hipanto cilíndrico, de 5-6 x 2,5-3,5 mm, lanoso pero menos densamente que en la flor estaminada, glabro interiormente; cáliz y corola similar a la de las flores estaminadas; estaminodios (4-)5, alternipétalos, diminutos, mameliformes o dentiformes con ápice redondeado, insertados cerca de la garganta del hipanto; ovario elipsoide, de 1-1,2 cm x 6-7 mm, 5-placentífero, con tricomas eglandulares filiformes, ascendentes; estilo columnar, glabro, ca. 2,5 mm de largo, con 3-5 ramas breves, poco notables; estigmas 2-lobulados, lóbulos en forma de " $U$ " (a veces oscuramente) de superficie papilosa. Fruto carnoso, elipsoide, ligeramente truncado en la base, ápice rostrado, de 2,5-4 x 2-2,5 cm, indehiscente, liso, con algunos tricomas blanquecinos ligeramente incurvos. Semillas ovado-elipsoides, comprimidas, ca. $5 \times 4 \mathrm{~mm}$, lisas, castañas, sin reborde manifiesto, con una banda de coloración más clara en el borde sagital. 
Distribución geográfica y hábitat. Especie de los Andes del S-SE del Perú, entre los 1900 y 2900 m s.m.; crece en laderas secas, abiertas, rocosas, con suelo somero, pedregoso (Fig. 27).

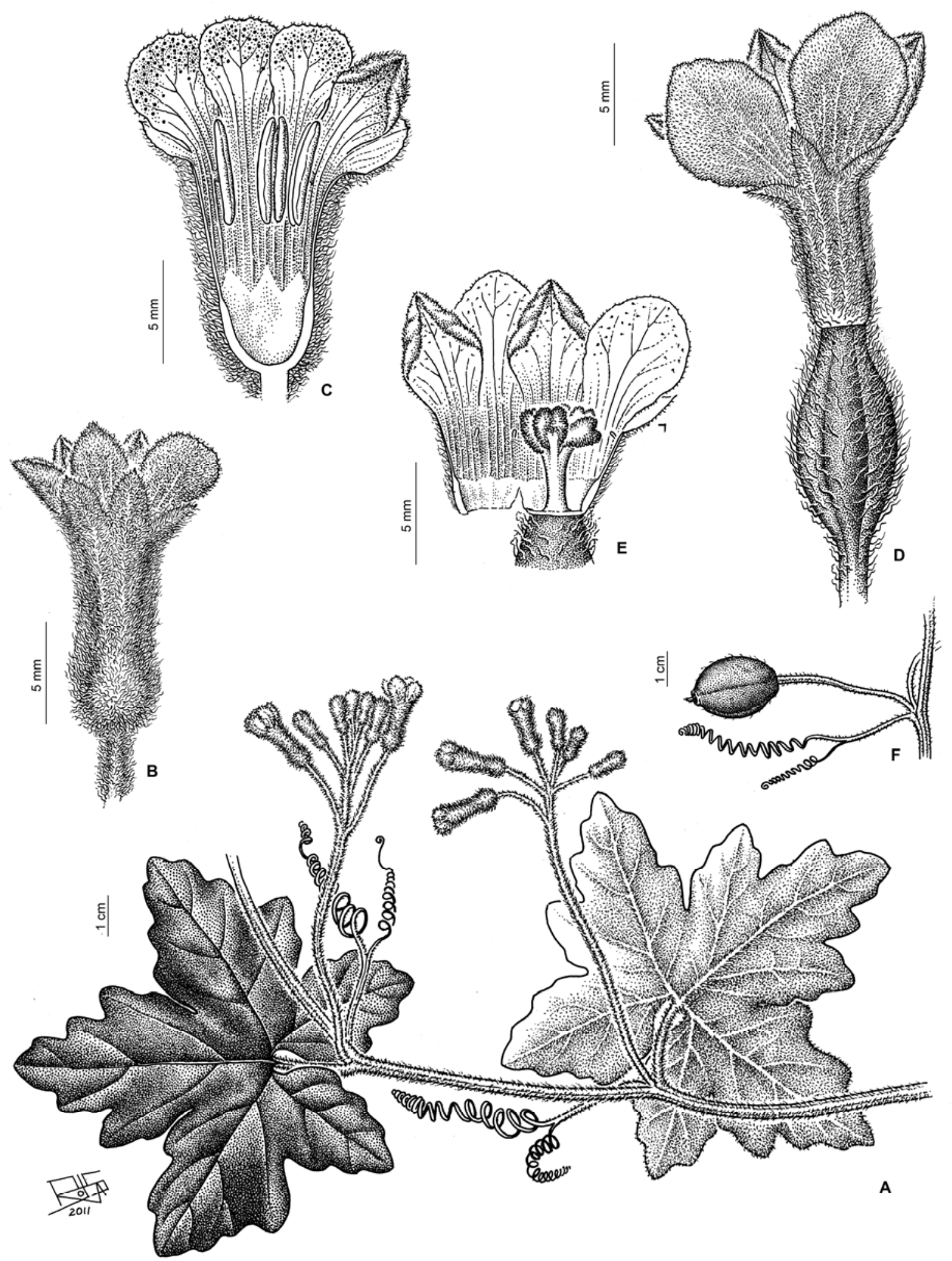

Figura 26. Apodanthera eriocalyx. A. Tallo con inflorescencias estaminadas. B. Flor estaminada, vista lateral. C. Flor estaminada, corte longitudinal. D. Flor carpelada, vista lateral. E. Flor carpelada, detalle del hipanto y el perianto desplegados. F. Fruto. (Dibujo de F. Rojas, Instituto Darwinion). A de Cerrate 1120. B-D de Weberbauer 7897. E-F de Goodspeed 30241. 


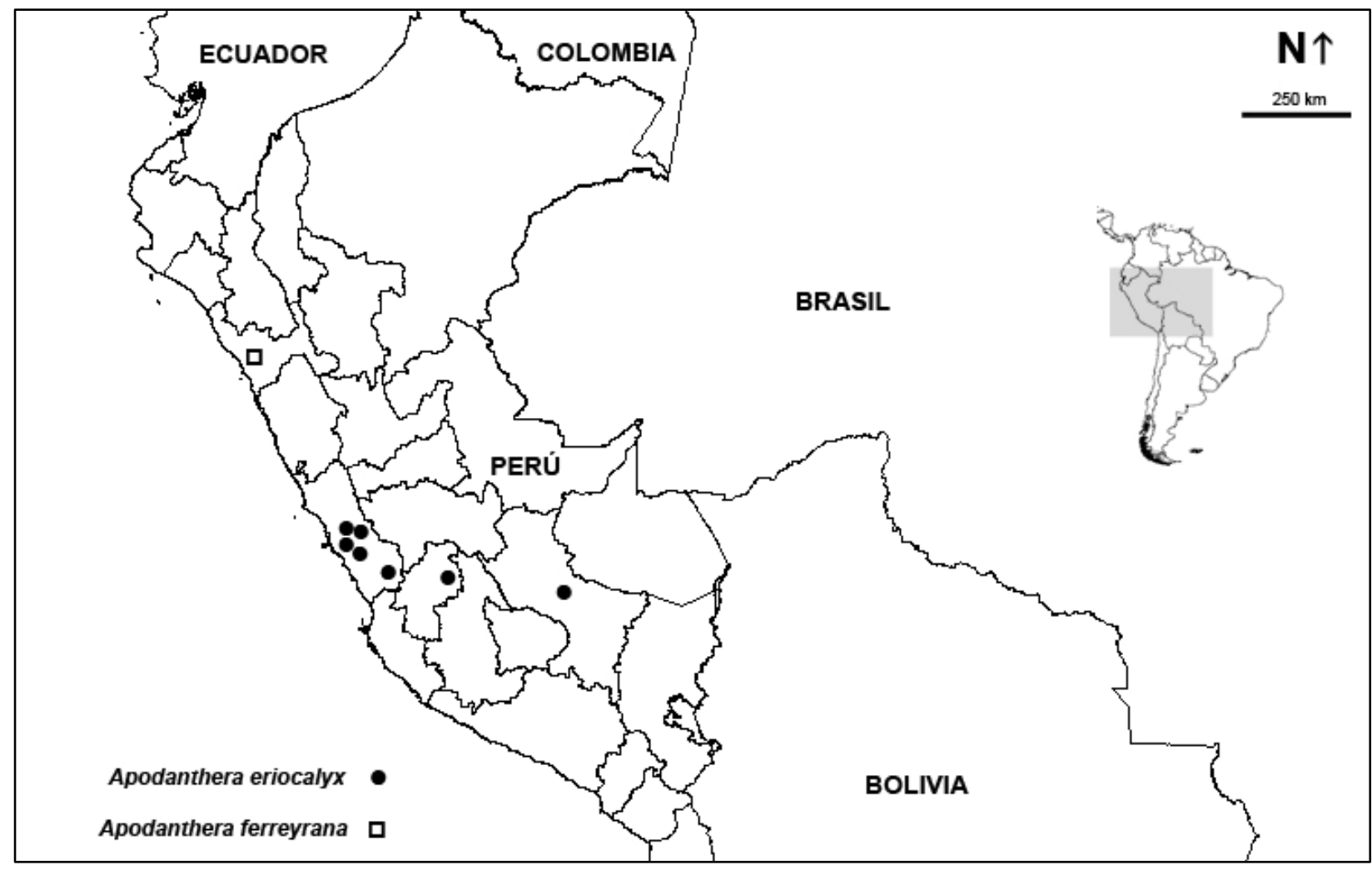

Figura 27. Distribución geográfica de Apodanthera eriocalyx y A. ferreyrana.

Etimología. El epíteto específico hace referencia al indumento lanoso del hipanto, del griego compuesto latinizado "erio" = lanudo y el latín "calyx" = cáliz.

Fenología. Florece y fructifica desde febrero hasta mayo.

Observación. Si bien en la descripción original de Apodanthera eriocalyx no se especifica el herbario en el que está depositado el ejemplar tipo (Weberbauer 5343), se presume que es el que está en el herbario BR, institución en la que trabajada el autor del nombre (A. Cogniaux), atendiendo a la recomendación 9A.4 del CINB.

Material adicional examinado. PERÚ. Cusco. Prov. Calca: Below Lares, 2900 m s.m., 7 Mar 1929, A. Weberbauer 7897 (F, GH, US). Huancavelica. Prov. Acobamba: vicinity of Acobamba, in flood plain and on the bottom of the deep valley of the Río Chalhuanca, $5 \mathrm{~km} \mathrm{NW}$ of Chalhuanca, 17 Dic 1962, H. H. Iltis et al. 602 (MO). Lima. Prov. Huarochiri: valley of Río Rimac, near Lima-Oroya highway at km 81 east of Lima, 2250 m s.m., 15/22 Mar 1942, T. H. Goodspeed et al. 30241 (UC). Chachauaro, entre Chosica y San Mateo, carretera Lima-La Oroya, 2500-2650 m s.m., 9 Mar 1953, R. Ferreyra 8957 (USM). Matucana, carretera central Lima-Oroya, 2400-2500 m s.m., 2 Abr 1950, R. Ferreyra 7049 (USM). Matucana, 8000 ft, 12 Abr - 3 May 1922, J. F. Macbride 337 (F); 14/18 Mar 1923, J. F. Macbride 2891 (F, US). Prov. 
Yauyos: Vichca, abajo de Tupe, 2700 m s.m., 8 Ene 1952, E. Cerrate 1120 (CTES, USM). Laraos, 2900 m s.m., 6 Feb 1989, H. Beltrán 122 (USM).

2. Apodanthera ferreyrana Mart.Crov., Bol. Soc. Argent. Bot. 6: 95. 1956. "Perú: Trujillo, depto. La Libertad, Cerro Campana, leg. R. Ferreyra no 8628, 18 VIII 1952 (UPM, typus specei)". TIPO. Perú. Dpto. La Libertad. Trujillo. Cerro Campana cerca de Trujillo, 18 Ago 1952, 400-500 m s.m., R. Ferreyra 8628 (holotipo, USM; isotipos, BAB-143!, MO2928989!). Figura 28.

Hierbas perennes, diclino-monoicas, zarcillosas; tallos anuales robustos, hasta de $4 \mathrm{~mm}$ de diámetro, estriados longitudinalmente, glabrescentes, pubescentes sólo cerca de los nudos; entrenudos hasta de $16 \mathrm{~cm}$ de largo; pecíolos robustos, de 2,5-3,5 cm x 1,5-2,5 mm (algo más anchos cerca de la lámina), estriados longitudinalmente, hírtulos; láminas anchamente ovadas, notoriamente 3-lobadas, a veces los lóbulos laterales sub-2-lobados, de 9-19,5 x 10-22 cm, base profundamente cordada, ápice agudo, margen subentero, remotamente denticulado, membranáceas, ligeramente discolores, cara adaxial verde, escabrósula con tricomas eglandulares cónicos, de base multicelular persistente, esparcidos, cara abaxial algo más pálida, tenuemente tomentosa, principalmente sobre los nervios, con tricomas eglandulares cónicos, de base unicelular, robustos y adpresos, lóbulo central lanceolado u obovado-elíptico, de 8,5-11 x 4,7-6,5 cm, los lóbulos laterales son menores y algo asimétricos entre sí. Zarcillos compuestos, 2-fidos, estriados, con tricomas eglandulares cónicos, de base unicelular, dispersos, el portazarcillos es más o menos recto, hasta de $3,5 \mathrm{~cm}$ de largo. Inflorescencia estaminada 5-8-flora, racemiforme, pedunculada; pedúnculo ascendente, hasta de $12 \mathrm{~cm}$ de largo, estriado, esparcidamente hispídulo a glabrescente; pedicelos de 5-7 mm de largo en flores abiertas, hispídulos, más profusamente hacia el ápice, con tricomas eglandulares cónicos con base unicelular, robustos, con célula apical aguda, algunos patentes, otros algo arqueados. Flores estaminadas ebracteadas; hipanto subcilíndrico-infundibuliforme, de 1-1,4 cm de largo x 2-2,5 mm de ancho en la parte media y 3-4 mm de ancho en la garganta, ligeramente ensanchado en la base, exteriormente hispídulo como el pedicelo; sépalos subtriangulares, de 2,5-3 mm de largo, indumento como el hipanto y pedicelo; pétalos ovados o anchamente elípticos, con ápice agudo, margen finamente crenado, ca. $8 \times 5,5 \mathrm{~mm}$, amarillo-anaranjados, con 5(-7)-nervios principales, corta y ralamente pubescentes en la cara dorsal, notablemente punteado-glandulares en la cara ventral, con tricomas glandulares moruliformes; filamento brevísimo, glabro; conectivo angosto, hialino, glabro; tecas de 4,5-5,5 mm de largo, rectas o apenas arqueadas. Inflorescencia carpelada 1-flora; pedicelo estriado longitudinalmente, ca. 6 cm de largo, glabro; hipanto cilíndrico, de 7-8 mm de largo, glabrescente; sépalos lanceoladosubulados de 4-5 mm de largo; pétalos amarillos, anchamente elípticos a suborbiculares, ca. 10 
x $9 \mathrm{~mm}$, pubescentes exteriormente, punteado-glandulares (con tricomas moruliformes) en el interior; estaminodios 5, setiformes a linear-oblongoides, ápice redondeado a algo subulado, ca. $1 \mathrm{~mm}$ de largo; ovario oblongo-elipsoide, 5-placentífero, glabrescente, liso, de base subtruncada, ca. 2 x 1,5 cm, estilo columnar, glabro, ca. $10 \mathrm{~mm}$ de largo, con 5 ramas breves, estigmas profundamente 2-lobulados, lóbulos oblongoides, coherentes. Fruto carnoso, subgloboso, de 2,4 × 2,2 cm, de base redondeada o truncada y ápice levemente atenuado en rostro ancho, indehiscente, glabrescente, 10 estriado, pluriseminado. Semillas ovadoelipsoides, comprimidas, ca. $6 \mathrm{~mm}$ de largo, lisas, emarginadas, de color castaño, con una banda blanco-cremoso en el borde sagital.

Distribución geográfica y hábitat. Hasta el momento sólo es conocida por la colección tipo, realizada en el Cerro Campana, cerca de Trujillo, en el departamento La Libertad, entre los 400 y 500 m s.m. (Figura 27). Habita en la formación denominada "lomas", característica de la zona árida costera de Perú y norte de Chile (Atacama). El relieve presenta pampas, terrazas y cerros. El clima de esta región está influenciado por las corrientes fría del Perú y cálida del Niño; durante el invierno la corriente fría forma neblinas que precipitan lentamente en forma de gotitas ("garúas" en Perú, "camanchacas" en Chile) y favorecen el desarrollo de una vegetación efímera (Ferreyra 1983, Dillon \& Hoffmann 1997).

Etimología. Nombrada en honor de Ramón A. Ferreyra (1912-2005), reconocido botánico peruano, coleccionista del ejemplar tipo de la especie.

Fenología. Hallada en flor (flores estaminadas) y fruto en el mes de agosto.

Observación 1. No han podido estudiarse flores carpeladas de esta especie; los caracteres indicados en la descripición precedente fueron tomados de la descripción original y los detalles florales de la ilustración tomados de originales inéditos de R. Martínez Crovetto, autor de la especie.

Observación 2. Apodanthera ferreyrana es similar a $A$. mathwesii, de la cual se distingue principalmente por el indumento de la cara abaxial de la lámina (tenuemente tomentoso en la primera, profusamente tomentoso en la segunda), por el tamaño de los pétalos (8 vs. 4-4,5 $\mathrm{mm}$ ) y por el contorno de los frutos (subesféricos vs. elipsoides). Para esta tesis, $A$. ferreyrana se reconoce como independiente sólo en forma preliminar, hasta tanto sea posible estudiar un mayor número de muestras atribuibles a este taxón. 

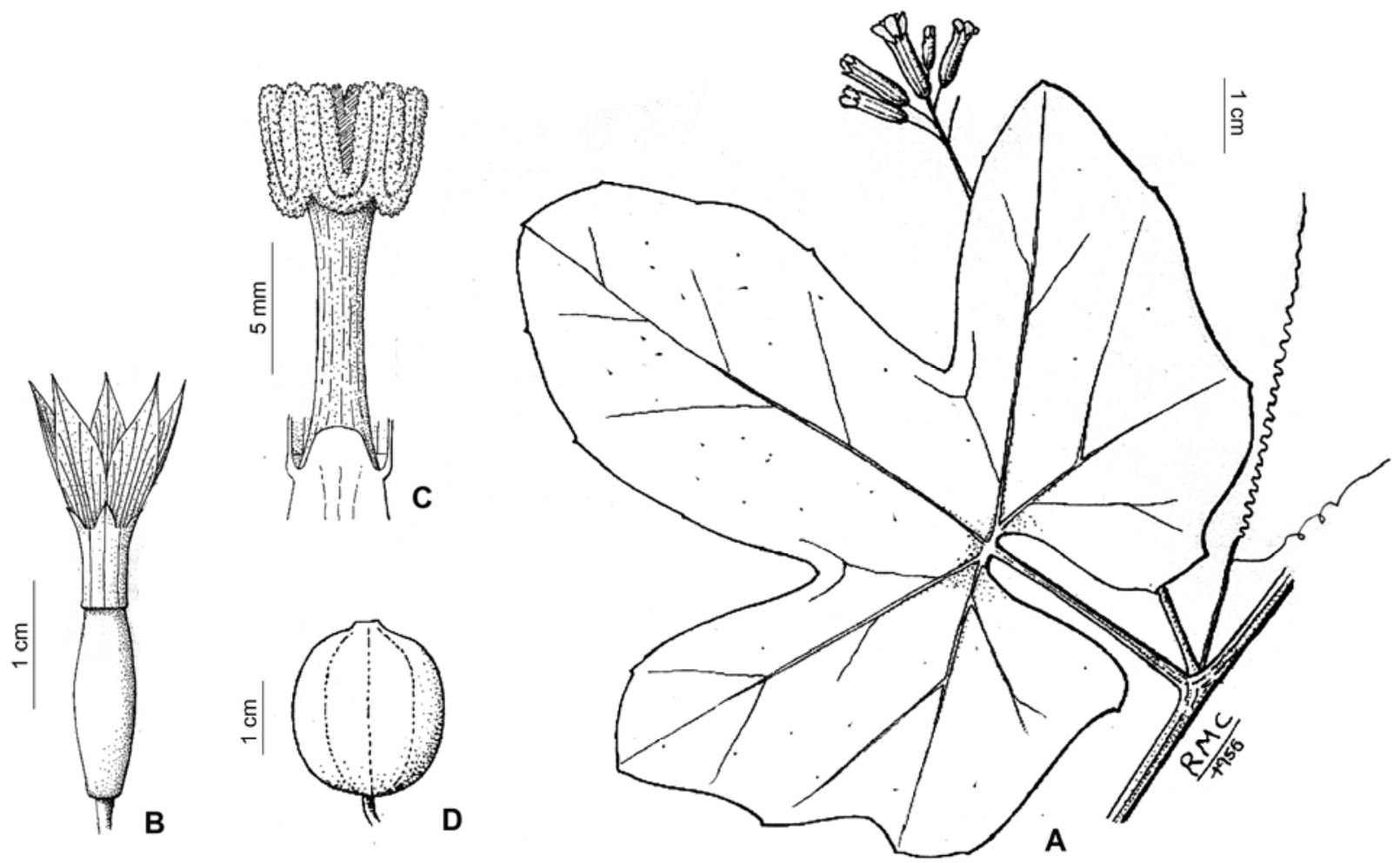

Figura 28. Apodanthera ferreyrana. A. Tallo con inflorescencia estaminada. B. Flor carpelada, vista lateral. C. Flor carpelada, detalle del ápice del ovario, estilo y estigmas. D. Fruto. (Dibujo inédito de R. Martínez Crovetto, CTES).

3. Apodanthera hirtella Cogn., Pflanzenr. 66 (IV. 275. I): 61. 1916. "Subäquatoriale andinae Provinz: Bolivia: Tucumilla bei Tarija, um 2800 m ü. M. (K. Fiebrig n. 2451. - Herb. Berlin)". TIPO. Bolivia australis. Tucumilla prope Tarija, alt. 2800 m, 30 Dic 1903, K. Fiebrig 2451 (lectotipo, BM-906024!, aquí designado; isolectotipos, BR-649 324!, G!, K430949!, L-602750!). Figuras 29 y 37.

Hierbas perennes, diclino-monoicas, zarcillosas; tallos anuales ca. 1,5 m de largo y 1,5-2,5 mm de diámetro, hirsutos, densamente en las partes jóvenes, más esparcidamente en las adultas, con tricomas eglandulares cónicos, de base unicelular, largos y punteagudos, patentes o adpresos; entrenudos de 5-12 cm de largo. Pecíolos de 7-20 x ca. 1,5 mm, densamente hirsutos; láminas palmatilobadas, de 6,5-10 x 8-14 cm, base ampliamente cordada, ápice de los lóbulos mucronulados, margen poco a marcadamente dentado, remotamente denticulado (hidátodos triangulares ca. 0,5 mm de largo), discolores, cara adaxial verde, cara abaxial verde grisáceo, tomentosas en ambas caras, con abundantes tricomas eglandulares, cónicos de base unicelular, adpresos, a veces la cara adaxial escabrósula por presencia de tricomas eglandulares cónicos, robustos, de base pluricelular persistente; las hojas jóvenes son a menudo 3-lobadas, con lóbulos ovado-elípticos, luego 5-lobadas con lóbulos centrales lanceolados, los laterales elípticos, notablemente menores. Zarcillos usualmente compuestos, 
2-fidos, portazarcillos hírtulos, hasta de 2,5 cm de largo. Inflorescencia estaminada 9-25-flora, largamente pedunculada, racemiforme, hasta de $25 \mathrm{~cm}$ de largo; pedúnculo hasta de $13 \mathrm{~cm}$ de largo, hírtulo; pedicelos filiformes, ascendenes o algo recurvos, de 6-22 mm de largo, persistentes, densamente hirsutos, con tricomas glandulares capitados simples. Flores estaminadas ebracteadas; hipanto subcilíndrico-infundibuliforme, de 1-1,4 cm de largo x 2-2,5 $\mathrm{mm}$ de ancho en la parte media y hasta de $4,5 \mathrm{~mm}$ de ancho hacia el ápice, la base es redondeada, exteriormente el hipanto es hirsuto, en forma uniforme o más profusamente hacia la base, a veces tornándose glabrescentes, con tricomas glandulares simples (capitados) rígidos y patentes, interiormente el hipanto es glabro; sépalos triangular-lanceolados, de 1,5-2 $\mathrm{mm}$ de largo x ca. $1 \mathrm{~mm}$ de ancho en la base, con indumento similar al del hipanto; pétalos obovados o anchamente elípticos, con ápice obtuso o truncado, margen entero, de 8-9 x 6-7 $\mathrm{mm}$, amarillos, 5 (u obscuramente 7) nervios principales, cortamente pubescentes en la cara dorsal, más profusamente hacia el ápice, con abundantes tricomas glandulares moruliformes en la cara ventral; tecas de $4 \mathrm{~mm}$ de largo. Inflorescencia carpelada 1-flora, usualmente en ramas distintas a las que portan las inflorescencias estaminadas; pedicelo ca. $2 \mathrm{~cm}$ de largo, esparcidamente piloso; hipanto cilíndrico, de 4-5 × $3 \mathrm{~mm}$, exteriormente glabrescente, interiormente glabro; sépalos triangulares ca. 1,5 mm de largo, apenas hírtulos exteriormente, con algunos tricomas robustos y tiesos, glabros internamente; corola similar a la de las flores estaminadas; estaminodios 3 , diminutos, con forma de pequeñas lengüetas, subiguales, a menudo 2 de ellos algo más anchos y sub 2-lobulados; ovario elipsoide, algo truncado en la base, de 6-10 x 2,5-4,5 mm, glabrescente, 3-placentífero; estilo de 2-3 mm de largo, con 3 ramas breves; estigmas 2-lobulados, con lóbulos oblongoides de superficie papilosa. Fruto (inmaduro) anchamente elipsoide, truncado en la base, de 2,6 $2 \mathrm{~cm}$, liso, glabro, verde. Semillas (inmaduras) ovado-elipsoides, comprimidas, de $4 \times 2 \mathrm{~mm}$, lisas, emarginadas, con una banda de color cremoso en el borde sagital.

Distribucion geográfica y hábitat. Crece en el centro-sur de Bolivia, desde el sudeste del departamento de La Paz, hasta el extremo noroeste de la Argentina (sierra de Santa Victoria y quebrada de Humahuaca, en la Cordillera Oriental), entre los 1850 y 3000 m s.m., en la Prepuna (Figura 30). Sus tallos anuales se extienden sobre las hierbas y arbustos circundantes.

Nombre vulgar. "Pampalacoya legítima" [Nee 36706 (K, NY, TEX)].

Etimología. El epíteto específico hace referencia a la pubescencia característica en tallos y hojas (del latín "hirtulus" = con pelos erectos y rígidos).

Fenología. Florece y fructifica de diciembre a marzo. 

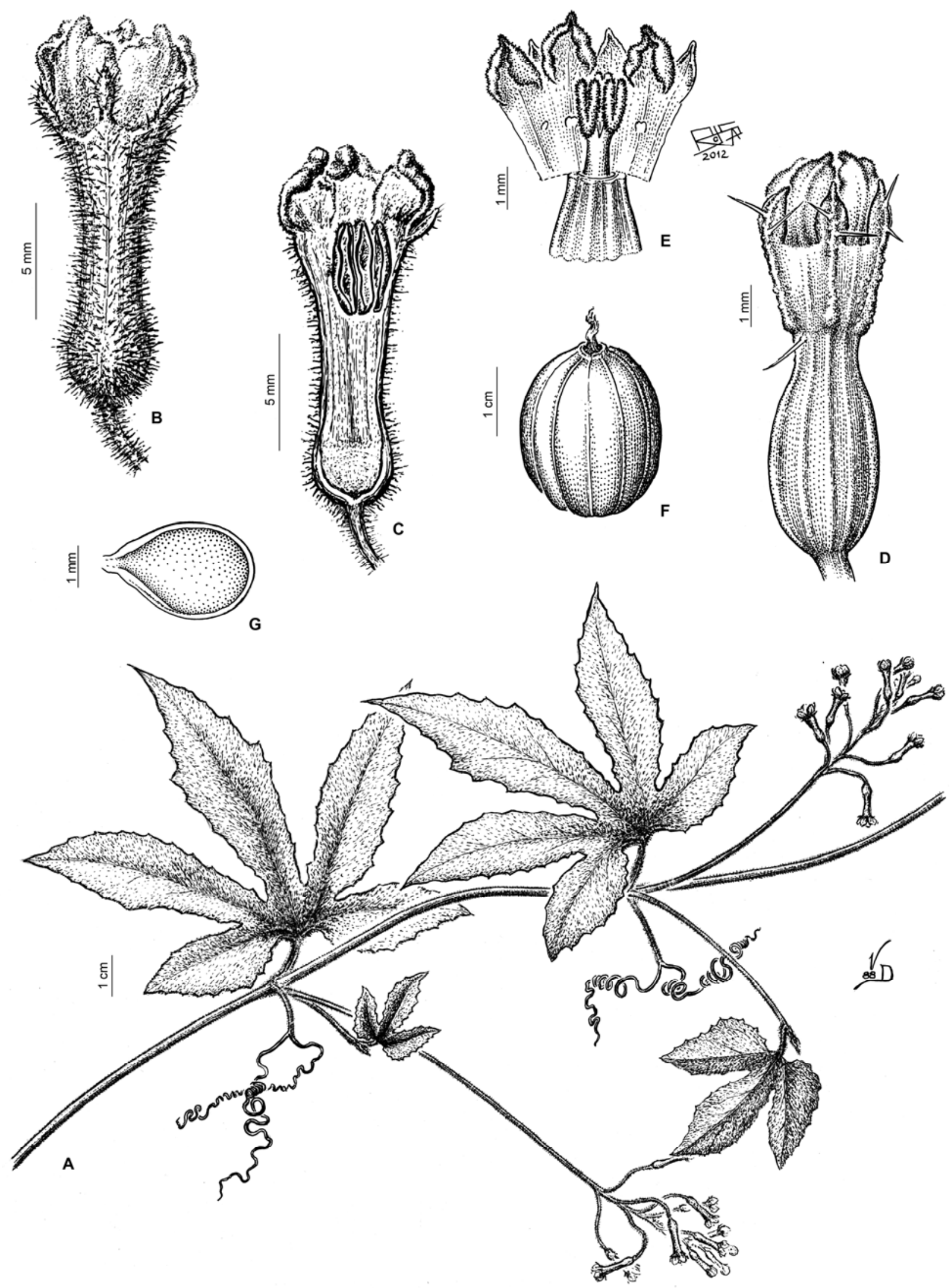

Figura 29. Apodanthera hirtella. A. Tallo con inflorescencias estaminadas. B. Flor estaminada, vista lateral. C. Flor estaminada, corte longitudinal. D. Flor carpelada, vista lateral. E. Flor carpelada, con hipanto y perianto desplegados. F. Fruto. G. Semilla. (A-C dibujo de V. Dudas; D-G dibujo de F. Rojas, Instituto Darwinion). A-C de Fabris 6311. D-G de Nee 36706. 
Observación. El holotipo en el herbario de Berlín (B) se ha destruido durante la Segunda Guerra Mundial, según comunicación personal del curador de la sección de fanerógamas de dicha institución, el Dr. Christoph Oberprier, en el año 2002. Por lo tanto, se ha procedido a elegir un lectotipo, según lo estipula el CINB (Art. 9.9 y 9.10). El espécimen elegido es un duplicado del holotipo (isotipo) depositado en el herbario del British Museum (BM) de Londres, y que ha podido ser estudiado detenidamente por el autor de esta tesis. Dicho espécimen se encuentra en muy buen estado de conservación y se ajusta perfectamente a la descripción original. Al igual que los demás isotipos localizados, este ejemplar cuenta únicamente con flores estaminadas. El isotipo en el herbario de Bruselas (BR), si bien se trata de la institución en la que trabajó el autor del nombre (A. Cogniaux), posee únicamente una hoja y dos porciones de inflorescencia separadas, resultando insuficiente para caracterizar a la especie.

Material adicional examinado. ARGENTINA. Jujuy. Dpto. Tumbaya: Volcán, cantera, $2100 \mathrm{~m}$ s.m., 9 Ene 1966, H. A. Fabris et al. 6311 (SI). Salta. Dpto. Santa Victoria: Santa Victoria, 2500 m s.m., 23 Ene 1998, R. Kiesling 8924 (SI). BOLIVIA. Cochabamba. Prov. Ayopaya: ca. 2 km below Independencia along road descending valley below hospital, 11 Mar 2000, J. R. I. Wood 15980 (K). La Paz. Prov. Inquisivi, 6,5 km SE of Inquisivi, 1-2 km SW of Machacamarca, 1656'S 67005'W, 3000 m s.m., 18 Mar 1988, M. Nee 36706 (K, NY, TEX). Tarija. Prov. Cercado: área de Ceramitar, ca. 1850 m s.m., 23 Dic 1985, E. Bastián 228 (K). Rincón de la Victoria, 2200 m s.m., 27 Ene 1953, T. Meyer 17483 (LIL).

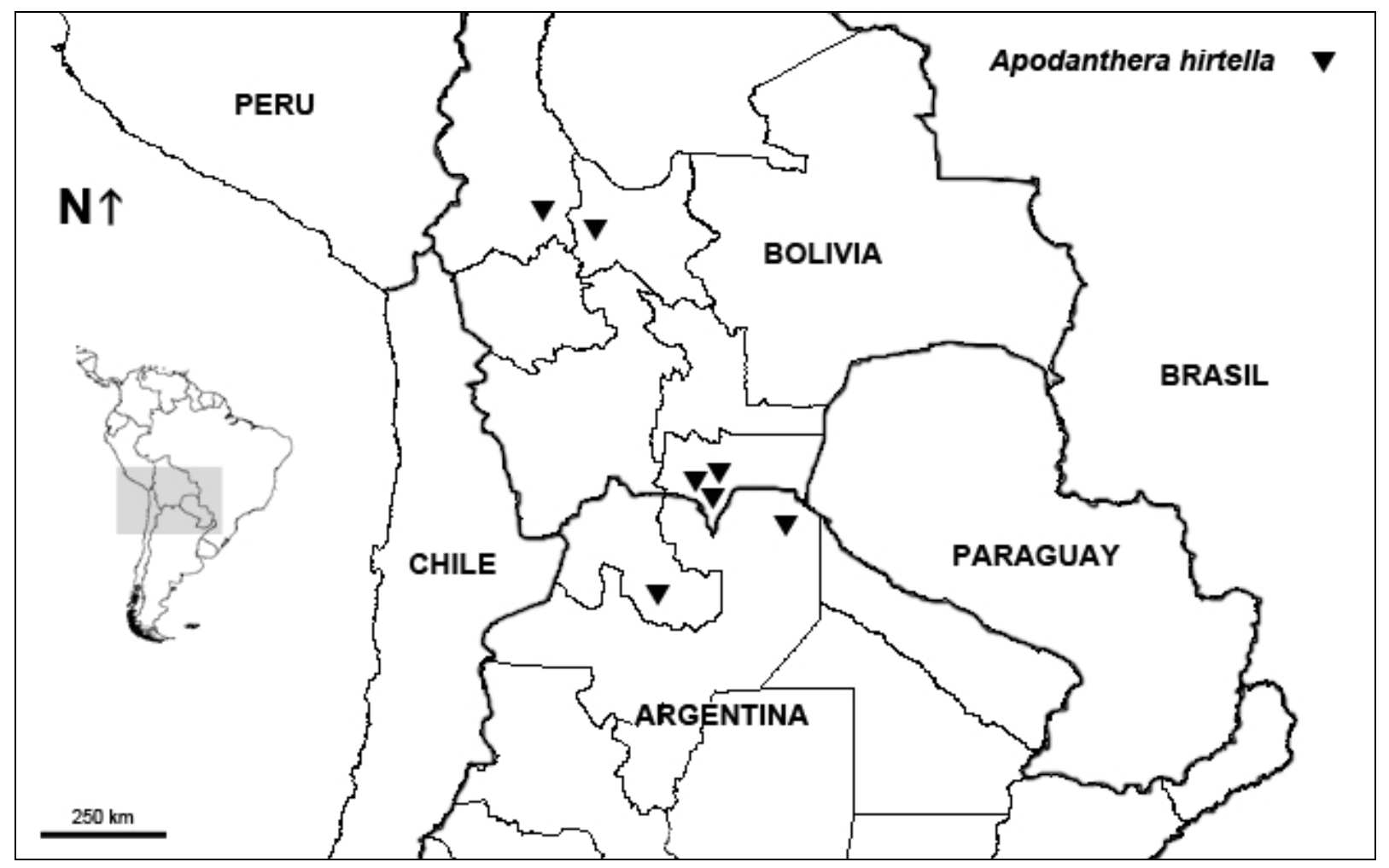

Figura 30. Distribución geográfica de Apodanthera hirtella. 
4. Apodanthera mandonii Cogn., Mém. Couronnes Autres Mém. Acad. Roy. Sci. Belgique 27: 41. 1877. "In Bolivia: Prov. Larecaja, vicinii Sorata; Poquerani in gypsosis; altit. 2650 met.; mart. 1860 (G. Mandon, PI. Andinum Boliv., no 1045, in hb. DC., Franquev., Vindob., Kew)." TIPO. Bolivia. Prov. Larecaja. Vicinii Sorata; Poquerani in gypsosis, $2650 \mathrm{~m}$, Mar 1860, G. Mandon 1045 (lectotipo, K-430960!, aquí designado; isolectotipos, BM-906025!, F-880685!, F-972039!, G, GH-31805!, K-430961!, K-430962!, NY-172325!, P-257365!, P751819!, S-05-1818!, Foto Serie Field Museum no 27116!). Figuras 31 y 37.

Apodanthera mandonii Cogn. var. dissecta Cogn. Mém. Couronnes Autres Mém. Acad. Roy. Sci. Belgique 27: 41. 1877. "In Peruvia (Cl. Gay, no 1967, ann. 1839-1840, in hb. Mus. Paris)". TIPO. Perú, 1839-1840, C. Gay 1967 (holotipo, P-752500!; isotipo, BR-649 318! fragmento ex P). Syn. nov.

Apodanthera mandonii Cogn. var. canescens Cogn. Mém. Couronnes Autres Mém. Acad. Roy. Sci. Belgique 27: 41. 1877. "In Peruvia (Cl. Gay, no 1815, ann. 1839-1840, in hb. Mus. Paris)." TIPO. Perú, 1839-1840, C. Gay 1815 (holotipo, P-257366!; isotipo, BR-649 323! fragmento ex P). Syn. nov.

Apodanthera herrerae Harms, Notizbl. Bot. Gart. Berlin-Dahlem 11: 770. 1933. "Peru: Prov. de Guispicanchi, distr. de Oropesa, Huasco, 3200 m (Blüh. I. 1926.- F. L. Herrera); einh. Name: ckotockoto". TIPO. Perú. Dpto. de Quispicanchi. Oropesa. Huasao, Ene 1926, 3200 m, F. L. Herrera 3038 (lectotipo, F-630148!, aquí designado). Syn. nov.

Apodanthera moqueguana Mart.Crov., Bol. Soc. Argent. Bot. 6: 94. 1956. "Perú: Moquegua, Carumas, leg. Weberbauer no 7263, II/III-1925, (F, typus speciei, G, US) y no 7273a, II/III1925, (F, G, US)". TIPO. Perú. Prov. Moquegua. Carumas, 21 Feb - 6 Mar 1925, climbing shrubs of stony slopes; fl. orange, fruit green with white spots, 2900-3000 m, A. Weberbauer 7263 (lectotipo, F-552482!, aquí designado; isolectotipos, BM-906037!, G, US-1482602!). Syn. nov.

Hierbas perennes, diclino-monoicas, zarcillosas; tallos anuales 2-3,5 mm de diámetro, estriados longitudinalmente, esparcidamente híspidos, con tricomas eglandulares cónicos, de base unicelular, agudos, algo patentes, tornándose glabrescentes; entrenudos de $6,5-18 \mathrm{~cm}$ de largo. Pecíolos robustos, de 1-3 cm x 1,5-2 mm, estriados longitudinalmente, escasa a densamente híspids; láminas de contorno anchamente ovado o subpentagonal, profundamente 5-lobadas (hasta la mitad de la lámina o más profundamente) o 5-sectadas, de 3,6-14,5 x 3,8$12,5 \mathrm{~cm}$, base profunda y ampliamente cordada, membranáceas, marcadamente discolores, la cara adaxial verde, la cara abaxial más pálida, con indumento de tricomas eglandulares cónicos de base unicelular, esparcidos en la cara adaxial y a menudo muy profusos, adpresos y entrelazados en la abaxial, que resulta densamente bronceado-tomentosa; lóbulo central ovado o lanceolado, los laterales menores, mucronulados o mucronados, margen 
irregularmente sinuado, dentado o lobulado, remotamente denticulado (hidátodos), algunas veces el margen puede estar ligeramente involuto. Zarcillos usualmente compuestos, 2-fidos, finamente estriados, glabrescentes o con unos pocos tricomas eglandulares cónicos, agudos; portazarcillos erectos hasta de $6 \mathrm{~cm}$ de largo. Inflorescencia estaminada 5-22-flora, pedunculada, racemiforme; pedúnculo ascendente, hasta de $14,5 \mathrm{~cm}$ de largo, finamente estriado, hirsuto o esparcidamente hispídulo, con tricomas glandulares capitados, simples, tornándose glabrescente; pedicelos de 0,7-3,5 cm de largo en flores abiertas, hirsutotomentosos, con abundantes tricomas glandulares capitados, simples. Flores estaminadas usualmente ebracteadas, algunas veces con una bráctea filiforme de 2-4 $\mathrm{mm}$ de largo en la base del pedicelo; hipanto subcilíndrico-infundibuliforme, de 1,1-1,6 cm de largo x 2-3,5 mm, algo más ancho en la garganta, base atenuada hacia el pecíolo o redondeada, densamente hirsuto-tomentoso en la superfcie exterior, con tricomas glandulares simples, capitados, patentes o algo adpreso-ascendentes que lo cubren completamente, interiormente el hipanto es glabro; sépalos subtriangulares ca. $1,5 \mathrm{~mm}$ de largo, con indumento similar al del hipanto; pétalos obovados a suborbiculares, de 6-7,5 x 6-7 mm, amarillos, corta y densamente pubescentes en la cara externa, glandular-pubescentes en la interna, con tricomas moruliformes; filamento muy breve, glabro; conectivo angosto, glabro, tecas ca. $5 \mathrm{~mm}$ de largo, subrectas. Inflorescencia carpelada 1-flora, rara vez co-axilar con la estaminada; pedicelo de 2$5 \mathrm{~cm}$ de largo, ralamente hirsuto, luego glabrescente en el fruto; hipanto subcilíndrico, de 3-6 $\mathrm{x}$ 2,2-3,5 $\mathrm{mm}$, exteriormente con tricomas glandulares simples, capitados, patentes o algunas veces adpreso-ascendentes, glabro interiormente; sépalos subtriangulares a ensiformes, de 1,5-4,5 mm de largo, con indumento similar al del hipanto; pétalos obovados a suborbiculares de 7-10 x 6-9 mm, muy densa y cortamente pubescentes en la cara exterior, glandularpubescentes en la interior (con tricomas moruliformes); estaminodios 3(-4)-5, diminutos, subiguales, mameliformes, dentiformes o subtriangulares con ápice redondeado, insertados cerca de la garganta del hipanto; ovario elipsoide, de 8-12 x 4-7 mm, con algunos tricomas glandulares simples, capitados, dispersos, patentes o algo ascendentes, (3-)5-placentífero, con la base truncada; estilo columnar, glabro, de 1-4,5 mm de largo, con (3-)5 ramas breves o algo notables; estigmas 2-lobulados, lóbulos en forma de "U" (a veces oscuramente), de superficie papilosa. Fruto carnoso, elipsoide, ligeramente truncado en base y ápice, rostrado, de 2,5-4,2 x 1,3-2,5 cm, indehiscente, liso, glabrescente o con indumento ralo, verde, con algunos puntos blancos. Semillas ovado-elipsoides, comprimidas, ca. 5-6 x 4-4,5 mm, lisas, castañas, sin margen prominente en relieve, con una banda de castaño claro en el borde sagital.

Nombres vulgares. "Ccoto-ccoto" [Vargas 9775 (F, GH, UC)], "kutu-kutu" [Brunel 84 (F, GH], "walpa-walpa" [Brunel 20 (MO)]. 
Distribución geográfica y hábitat. Especie propia de los Andes del centro y sur de Perú y oeste de Bolivia (Figura 32). Habita en ambientes xerofíticos, en quebradas secas, entre los 2400 y 3500 m s.m., sobre laderas rocosas, expuestas, cubiertas de vegetación arbustiva (especies de Verbenaceae, Grindellia Wild., Krameria Loefl., entre otros) o bien en el fondo de valles más húmedos, extendiéndose sobre la vegetación leñosa ribereña; también ha sido citada como creciendo en los bordes de áreas cultivadas.

Etimología. Dedicada al coleccionista del ejemplar tipo, el francés Gilbert Mandon (1799-1866), pionero de la exploración botánica en Bolivia.

Fenología. Florece y fructifica en primavera y verano, desde mediados de octubre hasta mediados de marzo.

Observación 1. En la descripción original de Apodanthera mandonii, A. Cogniaux indicó que el ejemplar tipo (G. Mandon 1045) posee duplicados en los herbarios G, K, P y W, no especificando una institución en particular. Según el CINB (Art. 9.4), podría interpretarse que los mencionados duplicados son sintipos ("Un sintipo es todo ejemplar citado en el protólogo, cuando no hubo designación de holotipo"). Por lo tanto, se procedió a designar un lectotipo (CINB, Arts. 9.9 y 9.10). El especimen elegido es el depositado en el herbario de Kew (con código de barras 430960), el cual fue mencionado en el protólogo y por lo tanto estudiado por el autor del nombre, posee una etiqueta completa que se corresponde, al igual que las características de la planta, con la descripción original. Dicho especímen posee inflorescencias tanto estaminadas como carpeladas y frutos y se encuentra en buen estado de conservación.

Observación 2. En la descripción original de Apodanthera herrerae no se indica el herbario de depósito del ejemplar tipo (Herrera 3038). No se ha localizado el mismo en el herbario de Berlín (B), donde el autor del nombre trabajaba, por lo tanto se ha procedido a designar un lectotipo, según los Arts. 9.9 y 9.10 del CINB. Se ha elegido un duplicado del tipo en el herbario del Field Museum de Chicago (F), el cual se ajusta perfectamente al protólogo y está en perfecto estado de conservación.

Observación 3. Apodanthera moqueguana fue segregada por R. Martínez Crovetto en función de sus ovarios 3-placentíferos y sus estilos con 3 ramas bien diferenciadas; sin embargo, se ha observado que estos caracteres pueden variar, incluso dentro de un mismo ejemplar, encontrándose flores carpeladas con 3,4 ó 5 placentas y ramas estilares de diversa profundidad. En el protólogo de $A$. moqueguana se indica que el ejemplar tipo está depositado en el herbario $\mathrm{F}$; en esta institución se encuentran dos láminas de esta colección, entre las que se ha elegido a la que lleva el número F-552482 como lectotipo (CINB, Art. 9.14). 
Observación 4. En ejemplares de herbario se ha indicado que las plantas desprenden un olor desagradable, intenso, ácrido, químico [Stafford 979 (F), Weigend 2000/165 (NY)].

Observación 5. Esta especie es muy similar a Apodanthera mathewsii, de la cual se separa principalmente por el grado de división de la lámina foliar y el indumento del hipanto (ver clave de especies). Sin embargo, estos caracteres suelen ser muy variables en el género, de modo que en el presente trabajo se aceptan como especies independientes de forma provisoria, tal vez se trate de variedades de una misma especie.

Material adicional examinado. BOLIVIA. La Paz. Prov. Inquisivi: Río Churu, $200 \mathrm{~m}$ W of Aquilani to $1 \mathrm{~km}$ above the main fork up river, $3 \mathrm{~km}$ SE of the ruins of Choquecamiri, $17 \mathrm{~km} \mathrm{~N}$ of Choquetanga, 16²42'S 67020'W, 2400-2500 m s.m., 29 Nov 1991, M. Lewis 40724 (LPB, MO). PERÚ. Apurímac. Prov. Abancay: Cachora, 2950, Ene 1950 C. Vargas 9128 (LIL). Curahuasi, 2800 m s.m., Ene 1950, F. Marin 1881 (F, LIL). Arequipa. Prov. Condesuyos: Chuquibamba, 9500 ft, 1 Ene 1938, D. Stafford 1173 (F). Prov. Grau: Hacienda Lucre, Oropeza Valley, 2600 m s.m., 18 Ene 1939, C. Vargas 9775 (F, GH, UC). Cusco. Prov. no consignada: Rencumayo, 29 Dic 1952, F. Woytkowski 196 (USM). Prov. Anta: El Chaccan, 3510 m s.m., 8 Nov 1972, G. R. Brunel 20 (MO); 3498 m s.m., 23 Nov 1972, G. R. Brunel 84 (F, GH). Prov. Calca: km 35 on road from Cuzco to Urubamba, ca. 2 km NW of Pisac, 3500-4000 m s.m., 10 Ene 1983, W. D. Stevens 22083 (MO, NY, TEX, USM). Pisac, 24 Ene 1969, Soukup 6325 (US). Pisac, 3200 m s.m., Ene 1943, F. Marin 126 (LIL). In the vicinity of Hacienda Paucartica, 3150 m s.m., Ene 1937, C. Vargas 216 (GH, UC). Prov. Cusco: Cerro Sape, frente a Sacsahuamán, 3400 m s.m, 17 Nov 1947, R. Ferreyra 2666 (F, US, USM). Tipon, Zona Arqueológica, zona de transición, E de Cuzco, 3100-3460 m s.m., 2 Nov 1986, P. Núñez et al. 6441 (MO, USM). \pm 23 km de Cusco al SE, cerros alrededor del pueblo, 305-3200 m s.m., 16 Mar 1987, P. Núñez 7497 (MO, USM). Prov. Quispicanchi: Urcos, 10000 ft, 16 Oct 1937, D. Stafford 979 (F). Prov. Urubamba: Urubamba, Road from Chinchero to Urubamba, 3200-3500 m s.m., 5 Feb 2000, M. Weigend \& K. Weigend 2000/165 (NY). Charcahuailla, 2800 m s.m., 20 Ene 1949, C. Vargas C. 7642 (LIL, MO, US). Pomatales, $\pm 52 \mathrm{~km}$ de Cusco desde Pomatales, por Rapcca y Pachar en el camino ferroviario de Cusco a Quillibamaba, 2950-2800 m s.m., 6 Mar 1987, P. Núñez 7312 (F, MO, NY, USM). Moquegua. Prov. Mariscal Nieto: Carumas, 21 Feb-6 Mar 1925, 2400-2500 m s.m., A. Weberbauer $7273 a(F)$. 


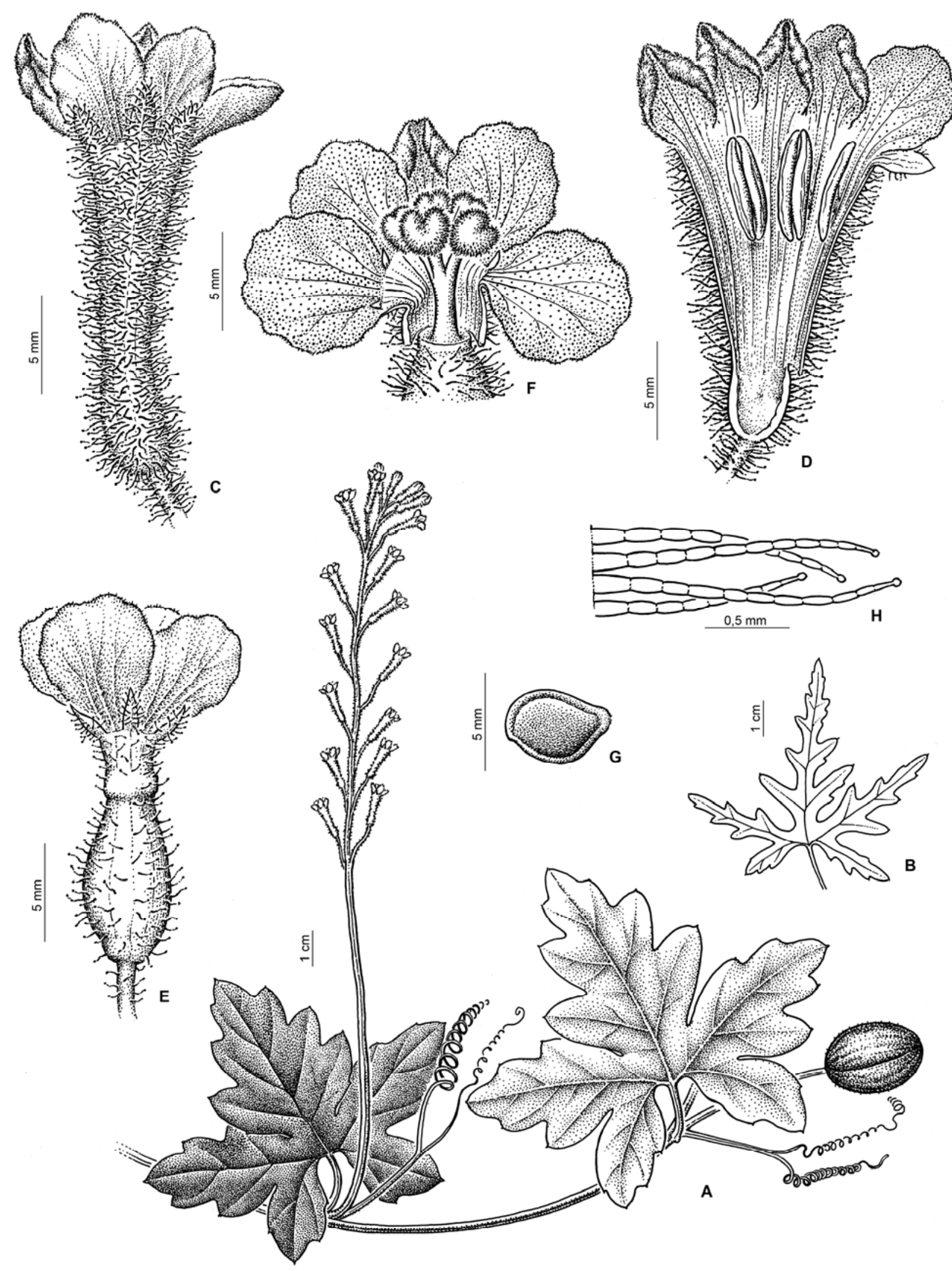

Figura 31. Apodanthera mandonii. A. Tallo con inflorescencia estaminada y fruto. B. Hoja sectada. C. Flor estaminada, vista lateral. D. Flor estaminada, corte longitudinal. E. Flor carpelada, vista lateral. F. Flor carpelada, con hipanto y perianto desplegados. G. Semilla. H. Tricomas glandulares capitados. (Dibujo de F. Rojas, Instituto Darwinion). A y H de Stevens 22083. B de Vargas 9775. C-E de Vargas 7642. F-G de Marin 1881. 


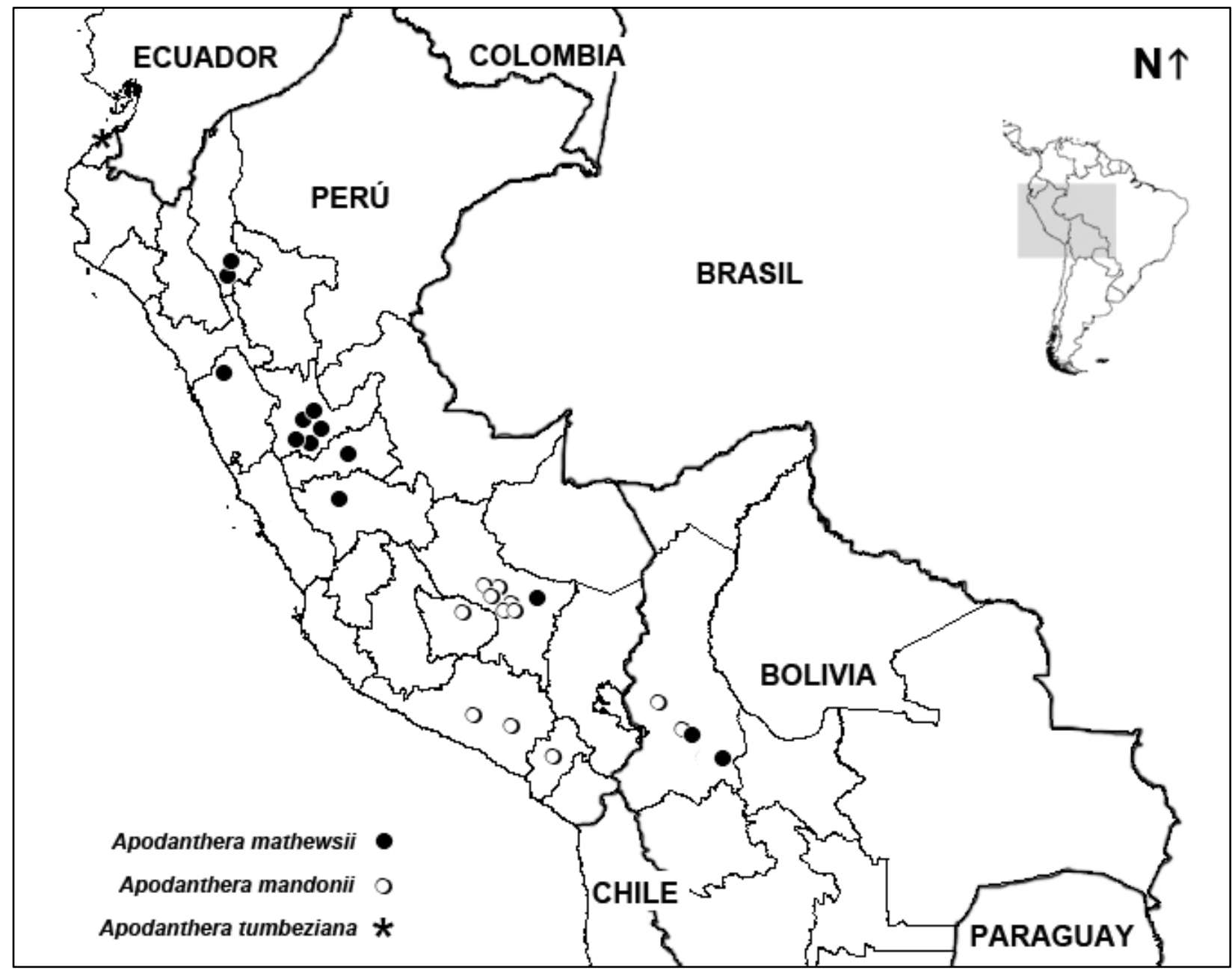

Figura 32. Distribución geográfica de Apodanthera mandonii, A. mathewsii y A. tumbeziana.

5. Apodanthera mathewsii Arn., J. Bot. (Hooker) 3(21): 274. 1841. "E Peruvia, (Mathews, No 932)". TIPO. Perú. Descr. Valley of Huanuco, 1833, A. Mathews 932 (lectotipo, K430959!, designado por A. Cogniaux, Mém. Couronnes Autres Mém. Acad. Roy. Sci. Belgique 27: 40. 1877; isolectotipos, BR-873 500! fragmento ex E, E-296296!). Figura 33.

Apodanthera mucronata Cogn., Mém. Couronnes Autres Mém. Acad. Roy. Sci. Belgique 27: 40. 1877. "In Peruvia? V. Raputu. Ruiz (Hb. reg. Berol.)". TIPO. Perú. Nueva España, 17781788 (Vulg. Raputu), H. Ruiz \& J. Pavón s.n. (lectotipo, G!, aquí designado; isolectotipo, F-844716!). Syn. nov.

Apodanthera latipetala Mart.Crov., Bol. Soc. Argent. Bot. 6: 96. 1956. "Perú: Cuzco, entre Cachu-Pampa y Chile-Chile, leg. Vargas no 9699, 10-XII-1938 (G, typus speciei, UC). TIPO. Perú. Depto. Cuzco. Prov. Quispicanchis, Disto. Marcapata, between Cachupampa and Chile-chile; among stone fences, 2300-2800 m, "Ccoto-ccoto", 10 Dic 1938, C. Vargas 9699 (holotipo, G; isotipos, F-1495934!, K-430950!, MO-1294073!, UC647093!). Syn. nov. 
Hierbas perennes, diclino-monoicas, zarcillosas; raíz tuberosa engrosada; tallos anuales hasta de 2,5 mm de diámetro, estriados longitudinalmente (ca. 10 costillas), densamente hirsutopubescentes en las partes jóvenes, esparcidamente en las adultas, con tricomas eglandulares cónicos, con base unicelular, agudos; entrenudos de 5,4-9,8 cm de largo. Pecíolos robustos, algo aplanados, de 1,2-3,3(-6,6) cm x 1,5-2,5 mm, estriados longitudinalmente, hirsutotomentosos; láminas anchamente ovadas o subpentagonales, subenteras a 3-5-lobadas, de 6$15(-25) \times 5,8-13,2(-24) \mathrm{cm}$, membranáceas, base profundamente cordada, margen apenas dentado, remotamente denticulado (hidátodos triangulares ca. 0,5 mm de largo), discolores, cara adaxial verde, esparcidamente pilosa o hispídula, cara abaxial albo-tomentosa, con tricomas eglandulares cónicos, de base unicelular, esparcidos en la cara adaxial, muy profusos, blancuzcos, entrelazados y adpresos en la abaxial, sobre los nervios principales los tricomas se disponen más profusamente y en forma perpendicular dando aspecto pestañoso; lóbulos anchamente elípticos, los laterales algo menores que el central, sub 2-lobados, de ápice redondeado a triangularmente obtuso, mucronado, el lóbulo central a veces apiculado. Zarcillos usualmente compuestos, 2-fidos, finamente estriados, hispídulos, portazarcillos más o menos rectos, hasta de $4(-8) \mathrm{cm}$ de largo. Inflorescencia estaminada 7-15-flora, pedunculada, inicialmente de aspecto subumbeliforme, luego racemiforme; pedúnculo ascendente, hasta de $18 \mathrm{~cm}$ de largo, estriado longitudinalmente, esparcidamente hirsútulo, con tricomas glandulares, capitados, simples, patentes; pedicelos de $1-3(-4,5) \mathrm{cm}$ de largo en flores abiertas, persistentes, hirsuto-tomentosos, con abundantes tricomas glandulares simples, capitados. Flores estaminadas ebracteadas; hipanto subcilíndrico-infundibuliforme, de 1-1,7 cm de largo x 2-3 mm de ancho en la parte media y 3-5 mm de ancho en la garganta, base ensanchada, exteriormente glabro a hirsuto cerca de la base, más esparcidamente hacia el ápice, con tricomas glandulares simples, capitados, patentes, rígidos, interiormente el hipanto es glabro; sépalos cortamente lanceolados, ensiformes o subulados, de 1,2-3(-5) mm de largo x ca. 1$1,5(-2,5) \mathrm{mm}$ de ancho en la base, a veces algo recurvos, con indumento similiar al del hipanto; pétalos obovados a anchamente elípticos, con ápice obtuso, redondeado o truncado, margen entero a finamente crenado, de 4-4,5 x 4-5 mm, amarillos, con 5 nervios principales, la cara dorsal afelpada, con tricomas uniseriados, simples, muy cortos y profusos, algunas veces con un mechón de pelos tiesos, más largos, sobre el nervio medio, la cara ventral con abundantes tricomas glandulares moruliformes; filamento muy breve, de $0,5 \mathrm{~mm}$ de largo, glabro; conectivo angosto, glabro; tecas de 4,5-5,5 $\mathrm{mm}$ de largo, rectas o apenas arqueadas. Inflorescencia carpelada 1-flora; pedicelo finamente estriado, de 1,5-2,5 cm de largo, luego alargándose hasta $7 \mathrm{~cm}$ en el fruto, hírtulo y tornándose glabrescente en el fruto; hipanto cilíndrico, de 5-5,5 x 5$5,5 \mathrm{~mm}$, hírtulo exteriormente, glabro interiormente; sépalos lanceolado-subulados, ca. $4 \mathrm{~mm}$ de largo x $2 \mathrm{~mm}$ de ancho en la base, hírtulos exteriormente, glabros internamente; corola similar a la de las flores estaminadas; estaminodios (4-)5, alternipétalos, a veces algo aproximados entre sí de a pares, quedando uno desapareado, diminutos, ca. 0,5 mm de largo, 
desiguales, dentiformes o triangulares, insertados cerca de la garganta del hipanto; ovario oblongoide a angostamente elipsoide, redondeado o truncado en la base, de 1-1,8 cm x 2,5-6 mm, (4-)5-placentífero, hispídulo, con tricomas glandulares simples, capitados, robustos; estilo columnar, glabro, de 2,5-4,5 mm de largo, con (4-)5 ramas breves; estigmas apenas o notablemente 2-lobulados, lóbulos en forma de "U" de superficie papilosa. Fruto carnoso, elipsoide, redondeado en ápice y base, de 4,5-10 x 2,2-6 cm, indehiscente, liso, verde, glabrescente; semillas ovado-elipsoides, comprimidas, de 6-7 x 2,8-3,5 mm, y ca. $2 \mathrm{~mm}$ de grosor, lisas, castaño oscuro o negruzcas, emarginadas, con una banda de color blanco cremoso en el borde sagital.

Distribución geográfica y hábitat. La especie se distribuye desde el norte de Perú, en el Cerro Campana, entre los 400 y 500 m s.m., y en los Andes centrales de Perú alcanzando hacia el sur, el oeste de Bolivia, entre los 2200 y 2800 m s.m. (Figura 32). Crece en laderas rocosas, expuestas, en bosques secos, con elementos espinosos; se ha indicado su presencia como ruderal, creciendo sobre muros derruidos de antiguas edificaciones y en terrazas de cultivo.

Nombres vulgares. "Ccoto-ccoto" [Vargas 9699 (F, G, K, MO, UC)]; "raputu” [Pavón s.n. (F, G)].

Etimología. Especie nombrada en honor de Andrew Mathews (1801-1841), botánico británico, coleccionista del ejemplar tipo de la especie.

Fenología. Frecuentemente florece y fructifica en primavera y verano, entre noviembre y marzo; también se han estudiado ejemplares con flores estaminadas coleccionados en mayo.

Observación 1. Se ha indicado que las plantas desprenden un olor desagradable, similar al de Cucurbitella asperata (Hook. \& Arn.) Walp.; adicionalmente, se ha señalado que las flores son visitadas por abejas, cerca de las 13:00 hs del día [M. Nee 53584 (SI)].

Observación 2. El tipo de Apodanthera mucronata en el herbario de Berlín (B) se ha perdido durante la Segunda Guerra Mundial; de este ejemplar sólo se conserva una fotografía de la serie Field Museum $n^{\circ}$ 8957. De acuerdo a lo estipulado en el CINB (Arts. 9.9 y 9.10), se procedió a lectotipificar este binomio; para ello se ha seleccionado un duplicado del tipo en el herbario del G, el cual se ajusta perfectamente al protólogo.

Observación 3. Apodanthera mucronata fue separada por sus hipantos glabros, sin embargo, este caracter es muy variable, encontrándose especímenes glabrescentes a otros hirsutos. Los pedicelos floríferos tienen la misma pubescencia secretora. Por lo demás, no se observan diferencias significativas para separarla de A. mathewsii. 

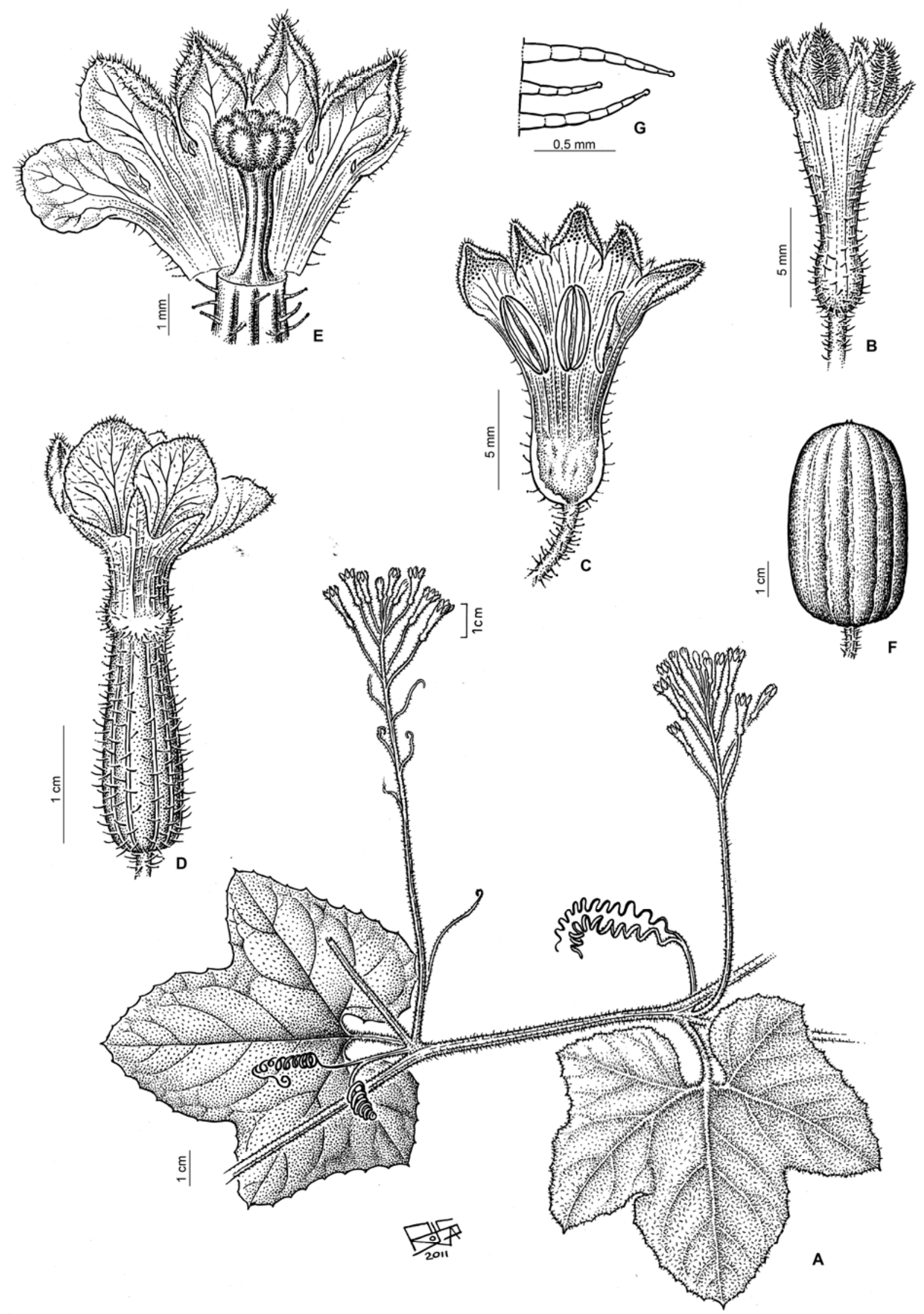

Figura 33. Apodanthera mathewsii. A. Tallo con inflorescencias estaminadas. B. Flor estaminada, vista lateral. C. Flor estaminada, corte longitudinal. D. Flor carpelada, vista lateral. E. Flor carpelada, con hipanto y perianto desplegados. F. Fruto. G. Tricomas glandulares capitados, simples, del hipanto. (Dibujo de F. Rojas, Instituto Darwinion). A, C-F de Nee 53584. B de Ferreyra 7107. G-I de Ochoa 471. 
Observación 4. En ancho relativo de los pétalos no puede ser considerado como un caracter consistente para separar a Apodanthera latipetala de las demás especies del género. Luego de estudiar el material tipo de esta última, no quedan dudas de que se trata de un sinónimo de $A$. mathewsii. El taxón muestra una amplia variación en la forma y dimensiones de sépalos y pétalos, existiendo una graduación desde sépalos triangualres hasta subulados y pétalos elípticos a suborbiculares.

Material adicional examinado. BOLIVIA. La Paz. Prov. Inquisivi: canyon of Río Khatu, 2 km (by air) N of Inquisivi on road to Chorocona, 1653'S, 67008'W, 2100-2200 m s.m., 12 Mar 1988, M. Nee \& J. Solomon 36663 (LPB, NY). Prov. Sud Yungas: Simpaya bei Yanacachi, 2200 m s.m., Dic 1911, O. Buchtien 225 (GH, NY, US). PERÚ. Amazonas. Prov. Chachapoyas: Distrito Leymebamba. Alredores del pueblo de Leymebamba, arriba del Río Atuén, 29 Ene 1999, E. Rodríguez R. \& C. Azabache L. 2149 (F). Cerca de Ubilon, entre Chachapoyas y Leymebamba, 1950-2000 m s.m., 12 Abr 1950, R. Ferreyra 7107 (US, USM). Ancash. Prov. Bolognesi: Conay, 6 km abajo de Chiquián, 2600 m s.m., 12 May 1950, R. Ferreyra 7384 (CTES, US, USM). Huánuco. Prov. Ambo: Ambo, 7000 ft, 5 Abr 1923, J. F. MacBride 3146 (F, US). San Rafael, 28 Oct 1927, M. Sawada 113 (F). Prov. Huánuco: ca. 1 km S of center of Panao, Purupampa and turnoff to Allpa Marca-Matacaballo, 9o 53' 36.7' S, 75 59' 01.1 W, $2550 \mathrm{~m}$ s.m., 13 Nov 2005, M. Nee 53584 (SI). Acomayo, near village, 4 Nov 1935, Y. Mexia 4112 (GH, MO, UC). Junín. Prov. Tarma: Gorge of Río Huasahuasi, $7 \mathrm{~km} E$ of Huasahuasi on road from Palca, 12 Ago 1957, P. C. Hutchison 1152 (F, USM). Pasco. Prov. Pasco: Salcanchupán, 2800 m s.m., 6 Abr 1948, Ochoa 471 (F, GH, US).

6. Apodanthera tumbeziana Harms, Notizbl. Bot. Gart. Berlin-Dahlem 11: 770. 1933. "Peru: Prov. Tumbez, Dep. Tumbez, Berge südöstlich von Hacienda La Choza, 800-900 m, Gebüsch mit abfälligem Laube (II.1927 - A. Weberbauer n. 7691 ঐ, 7691a + )". TIPO. Perú. Dpto. Tumbez. Tumbez, Mts. SE of Hacienda La Choza, 800-900 m, 27/28 Feb 1927, A. Weberbauer 7691 (lectotipo, F-571834!, aquí designado). Figura 34.

Hierbas perennes, zarcillosas; tallos anuales estriados (ca. 10 estrías longitudinales), de 1,2-2 $\mathrm{mm}$ de diámetro, ligeramente híspidos, con tricomas filiformes, patentes (más profusamente cerca de los nudos); entrenudos de 6-20 cm de largo; pecíolos algo aplanados, de 1,2-3,7 cm x 0,8-1,5 mm, estriados, hirsutos; láminas anchamente ovadas o subpentagonales, 3-lobadas u obscuramente 5-lobadas (los lóbulos laterales apenas 2-lobados), hasta el medio de la lámina o más profundamente, de 8-15,6 x 7-16 cm, base cordada, margen regularmente dentadocrenado, remotamente dentículado, con hidátodos ca. $0,5 \mathrm{~mm}$ de largo, de consistencia tenuemente membranácea, concolores, verdes, ambas caras de la lámina esparcidamente 
pilosas a glabrescentes, con tricomas eglandulares cónicos, algunos finos y largos, otros más robustos y cortos; lóbulos elíptico-lanceolados, de ápice mucronulado, el central de de 4,5-10,5 x 3,5-4,8 cm, los laterales menores. Zarcillos compuestos, 2-fidos, rara vez simples, finamente estriados, pilosos, cuando compuestos el portazarcillos es más o menos recto, hasta de $4 \mathrm{~cm}$ de largo. Inflorescencia estaminada hasta 11-flora, pedunculada, racemiforme; pedúnculo ascendente hasta de $12 \mathrm{~cm}$ de largo, estriado longitudinalmente, glabrescente en la porción inferior, esparcidamente híspido en la superior, con tricomas filiformes, patentes, hialinos, agudos; pedicelos flexuosos, de $1-3 \mathrm{~cm}$ de largo en flores abiertas, híspidos como el pedúnculo. Flores estaminadas ebracteadas; hipanto subcilíndrico-infundibuliforme, de 9-11 $\mathrm{mm}$ de largo x 2,5 mm de ancho en el ápice, donde está algo dilatado, la base ligeramente redondeada, pubescencia externa rala, con tricomas filiformes, ténues, interiormente el hipanto es glabro; sépalos triangular-lanceolados, de 1,5-2,5 mm de largo x 1-2 mm de ancho en la base, externamente con indumento similar al hipanto pero con tricomas más robustos, cónicos, hacia el ápice, internamente glabros; pétalos obovados, ápice cortamente apiculado, margen entero a finamente crenado, de 5-6 x $4 \mathrm{~mm}$, amarillos, obscuramente 7-9-nervios, cortamente afelpado-tomentosos en la cara dorsal, con tricomas glandulares moruliformes en la ventral; filamentos ca. 0,5 mm de largo, glabros; conectivo hialino, angosto, glabro; tecas ca. 4,5 mm de largo, rectas. Inflorescencia carpelada 1-flora; pedicelo hasta de $6 \mathrm{~cm}$ de largo en antesis, híspido, con tricomas eglandulares filiformes, hialinos, patentes; hipanto cilíndrico, de 8-9 × 4,5$5 \mathrm{~mm}$, esparcidamente híspido exteriormente, con algunos tricomas filiformes, hialinos, interiormente glabro; sépalos similares a los de las flores estaminadas; pétalos suborbiculares, enangostados en la base, de 9-10 mm de diámetro, estaminodios 3-4, dentiformes, redondeados en el ápice, insertados cerca de la garganta del hipanto, en posiciones intermedias; ovario angostamente ovado-elipsoide, de 1,5-1,8 cm x 6-6,5 mm, redondeado en la base, esparcidamente híspido, 5-placentífero; estilo columnar, glabro, ca. $4 \mathrm{~mm}$ de largo, dividido en 5 ramas profundas, bien notables, de largos desiguales; estigmas 2-lobulados, los lóbulos en forma de "U", de superficie papilosa. Fruto desconocido. Semillas desconocidas.

Distribución geográfica y hábitat. Sólo se la conoce del material original. Ha sido coleccionada en los cerros al sudeste de la Hacienda La Choza, en el departamento de Tumbes, extremo norte de Perú (Figura 32); ocupa el denominado "bosque seco subtropical" (Brack E. 2000).

Etimología. El epíteto específico alude a la localidad del ejemplar tipo, en el departamento Tumbes, en el extremo noroeste de Perú.

Observación 1. En la descripción original de Apodanthera tumbeziana, Harms citó dos ejemplares: A. Weberbauer 7691 (ejemplar estaminado) y 7691a (ejemplar carpelado). Por la numeración de estos ejemplares podría presumirse que se han preparado dos hojas de una 
misma colección, una con flores estaminadas y la otra con flores carpeladas. Sin embargo, no es posible asegurar que esto sea así; en esta tesis se los considera sintipos y se procede a la elección de uno de ellos como lectotipo del binomio (CINB, Arts. 9.2, 9.4, 9.9 y 9.10). No se han localizado ninguno de los sintipos antes mencionados en el herbario de Berlín, donde Harms trabajaba; por lo tanto, se ha elegido un duplicado del ejemplar estaminado, depositado en el herbario del Field Museum (F-571834), el cual se ajusta perfectamente al protólogo.

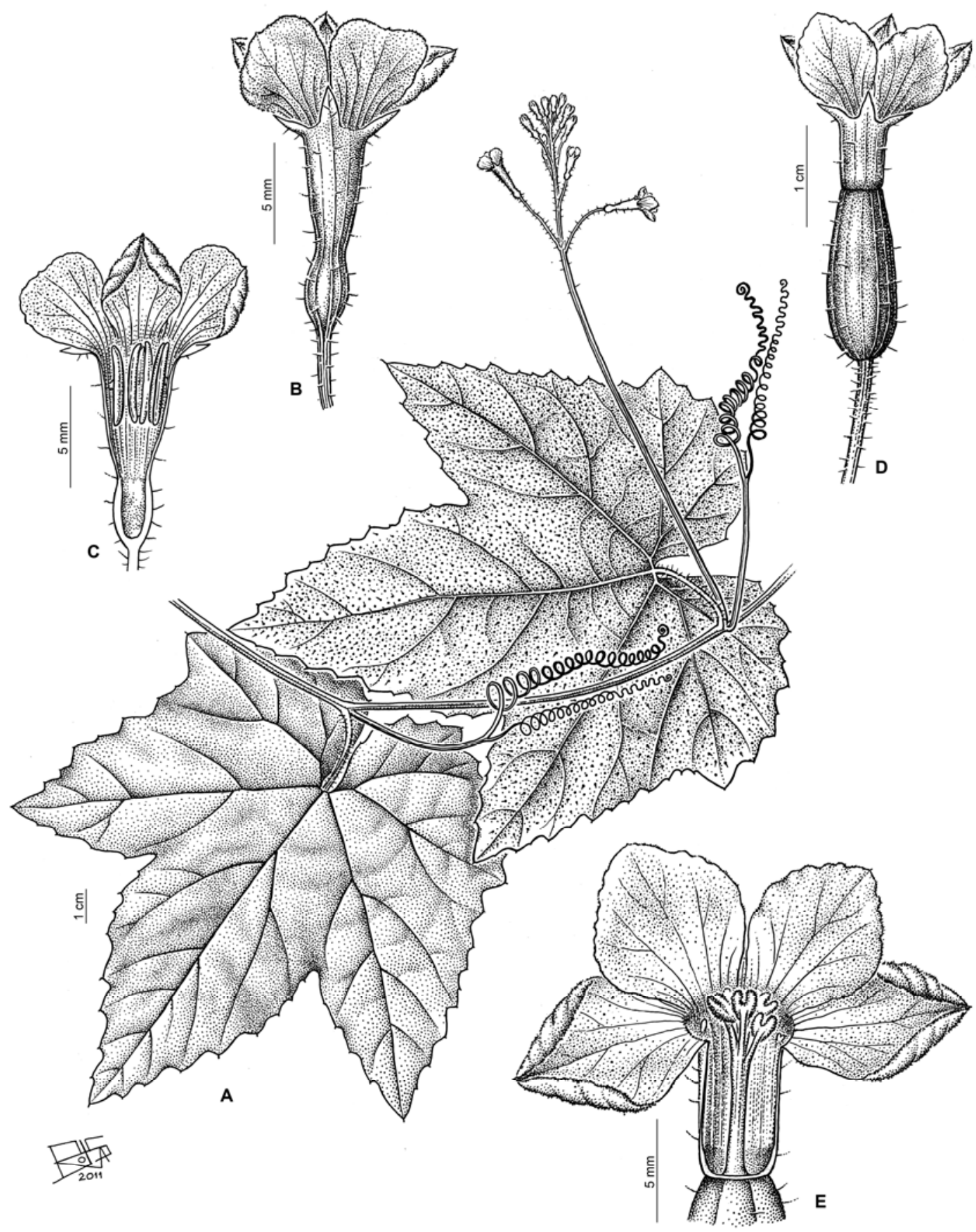

Figura 34. Apodanthera tumbeziana. A. Tallo con inflorescencia estaminada. B. Flor estaminada, vista lateral. C. Flor estaminada, corte longitudinal. D. Flor carpelada, vista lateral. E. Flor carpelada con hipanto y perianto desplegados. (Dibujo de F. Rojas, Instituto Darwinion). A-C de Weberbauer 7691. D-E de Weberbauer 7691a. 
Observación 2. A partir de los dos únicos ejemplares disponibles, no es posible verificar la monoecia de la especie, debido a que cada ejemplar presenta sólo un tipo de flores. No es posible determinar si ambos ejemplares pertenecen al mismo individuo o a individuos diferentes de la misma población (los datos de etiqueta son los mismos para ambos ejemplares). De todos modos, se presume que, al igual que las demás especies del género, $A$. tumbeziana es diclino-monoica, pudiendo presentar ramas con flores estaminadas, otras con flores carpeladas o ambos tipos (estaminadas y carpeladas) en la misma rama, dependiendo de la edad de la planta y de condiciones ambientales que puedan favorecer el desarrollo de flores de uno u otro tipo o de ambos.

Material adicional examinado. PERÚ. Tumbes. Prov. Tumbes: Mts. SE of Hacienda La Choza, 800-900 m s.m., 27-28 Feb 1927, A. Weberbauer 7691a (sintipo de A. tumbeziana, F-571835!).

7. Apodanthera weberbaueri Harms, Notizbl. Bot. Gart. Berlin-Dahlem 11: 771. 1933, "Peru: Dep. Lima, Prov. Chancay, Pativilca, Loma steinige Stellen, 200-300 m (VIII.1925. - A. Weberbauer n. 7485), Blüten goldbelb". TIPO. Perú. Dpto. Lima. Chancay, Pativilca, Loma, stony places, 200-300 m, 4 Ago 1925, A. Weberbauer 7485 (lectotipo, US1482608!, aqui designado; isolectotipos, BM-906036!, F-562390!, GH-31806!, K-430951!, P-751821!, S-05-1821!). Figura 35.

Hierbas perennes, diclino-monoicas, zarcillosas; raíz tuberosa; tallo perenne subterráneo, ca. 6 x 1,2 cm; tallos anuales gráciles, estriados longitudinalmente (ca. 10 costillas desiguales), ca. 1,5 $\mathrm{mm}$ de diámetro (hasta $2 \mathrm{~mm}$ en la base), híspidos, más abundantemente en los nudos, con tricomas eglandulares cónicos, de base unicelular, largos y agudos, patentes, tornándose glabrescentes; entrenudos de 3-14,5 cm de largo. Pecíolos delgados, de 1-2,4(-7) cm x ca. 1 $\mathrm{mm}$, finamente estriados, híspidos, con tricomas eglandulares cónicos, delgados, alargados y agudos, de base unicelular; láminas anchamente ovadas o subpentangonales, poco a profundamente 3-5-lobadas, de 3,8-10,4 x 4-11 cm, de base profundamente cordada, membranáceas, ligeramente discolores, algo más pálida en la cara abaxial, esparcidamente escabrosas en la cara adaxial, con tricomas cónicos de base pluricelular, tomentosas en la abaxial, con tricomas cónicos de base unicelular, adpresos, sobre los nervios estos tricomas son más robustos; la nerviación es muy notable en ambas caras; lóbulos de contorno lanceolado u ovado-elíptico, de ápice mucronulado, margen angulado o sinuado, irregularmente dentado, remotamente denticulado (hidátodos). Zarcillos simples, finamente estriados, esparcidamente hispídulos a glabrescentes. Inflorescencia estaminada 7-25-flora, con aspecto de umbela pedunculada; pedúnculo ascendente o erecto, hasta de $12 \mathrm{~cm}$ de largo, hispídulo; pedicelos hasta de $1 \mathrm{~cm}$ de largo en las flores basales de la inflorescencia, 
persistentes, densamente hirsutos, con tricomas glandulares simples, capitados, patentes. Flores estaminadas ebracteadas; hipanto subcilíndrico-infundibuliforme, de 9-12 mm de largo x 3-4 mm de ancho en el tercio superior, donde está notablemente ensanchado y en cuyo interior se alojan los estambres, en la zona media el hipanto es angosto, la base es usualmente redondeada, exteriormente el hipanto es hirsuto, con tricomas glandulares capitados simples, muy profusamente en los pimpollos, interiormente es glabro; sépalos de contorno triangular a triangular-lanceolado, ca. $2 \mathrm{~mm}$ de largo x 1,5 mm de ancho en la base, hirsuto-pubescentes; pétalos obovados o elípticos, de 4-6 mm de largo, con 2 lobulos laterales notables, ápice obtuso o truncado, margen entero, algo undulado en los lóbulos laterales, de color amarillo intenso, nervios poco evidentes, cara dorsal profusa y cortamente afelpado-tomentosa, con tricomas uniseriados, cortos con célula apical algo redondeada y algunas veces curvada, cara ventral con abundantes tricomas glandulares moruliformes; estambres insertados en el tercio superior del hipanto, insertos; anteras oblongoides, dorsifijas; filamento muy breve, glabro; conectivo hialino, algo expandido, con tricomas glandulares ampuliformes en el ápice; tecas ca. $3 \mathrm{~mm}$ de largo, rectas o apenas arqueadas. Inflorescencia carpelada 1-flora; pedicelo finamente estriado, ligeramente aplanado, hispídulo, más abundantemente hacia el ápice, con tricomas eglandulares cónicos de base unicelular, alargados y patentes, ca. $2 \mathrm{~cm}$ de largo, alargándose hasta $5,5 \mathrm{~cm}$ en el fruto; hipanto subcilíndrico, ensanchándose hacia el ápice, de 4-9 mm de largo x 2,5-5 mm de ancho en el ápice, indumento similar a la de las flores estaminadas; sépalos lanceolados, de 2,3-3 x 1,4-1,7 mm, hirsuto-pubescentes exteriormente, glabros interiormente; corola similar a la de las flores estaminadas; estaminodios 3-5, subiguales, triangular-lanceolados o setiformes, de 0,5-0,8 $\mathrm{mm}$ de largo, insertados en el tercio superior del hipanto, por debajo de la base de los pétalos, sub-opuestos o alternos a éstos; ovario oblongoide a fusiforme, apenas redondeado en la base, ca. 15 × 3,5 mm, 2-placentífero, hirsuto, con tricomas glandulares capitados, simples; estilo columnar, glabro, hasta de 6,5 mm de largo, con 2 ramas notables; estigmas obscuramente 2-lobulados, subglobosos, de superficie papilosa. Fruto carnoso, indehiscente, elipsoide, de 3-3,5 x 1,2-1,5 cm, base truncada, ligeramente apiculado y con rostro breve, esparcidamente hírtulo, verde con algunas marcas blanquecinas. Semillas ovado-elipsoides, comprimidas, ca. $5 \times 3 \mathrm{~mm}$, lisas, de color castaño, un poco más claro y apenas marcado en relieve en el borde sagital.

Distribución geográfica y hábitat. Especie endémica del noroeste de Perú, en los departamentos de Cajamarca y Libertad (Figura 36). Crece sobre hierbas y arbustos de los cerros costeros y hacia el interior, en laderas pedregosas, desde los 300 hasta los 2000 m s.m.

Etimología. Esta especie fue nombrada en honor de August Weberbauer (1871-1948), botánico alemán, quien realizara importantes investigaciones y colecciones botánicas en Perú, coleccionista del ejemplar tipo. 
Fenología. Florece y fructifica entre febrero y abril; los especímenes provenientes del cerro Campana se hallan en flor durante el mes de agosto.

Observación 1. En la descripción original de Apodanthera weberbaueri, Harms no especificó el herbario de depósito del ejemplar tipo (A. Weberbauer 7485). No se ha localizado a este ejemplar en el herbario de Berlín (B), lugar de trabajo de Harms y donde Weberbauer depositaba sus originales, presumiblemente destruido; por lo tanto se ha procedido a la designación de un lectotipo, según lo indica el CINB (Arts. 9.4, 9.9 y 9.10). Se ha elegido el duplicado del tipo (isotipo) en el herbario del Museo Smithsonian de Washington (US), el cual se ajusta perfectamente al protólogo y está en perfecto estado de conservación.

Observación 2. Apodanthera weberbauerii se distingue fácilmente de las demás especies del género por sus ovarios 2-placentíferos, pétalos lobulados, inflorescencias con aspecto de umbelas pedunculadas y presencia de tricomas en el ápice del conectivo (vs. ovarios 3-5placentíferos, pétalos enteros, inflorescencias racemiformes y conectivos glabros); estas características, la acercan, en cambio, al género Melothrianthus (véase más adelante en este capítulo). En el análisis filogenético $A$. weberbauerii se agrupó con las demás especies andinas de Apodanthera, en posición basal. Algunos de los caracteres morfológicos antes mencionados (como el número de placentas) han sido considerados como caracteres diagnóstico intergenéricos $\mathrm{y}$, por este motivo, en esta tesis se considera a la especia dentro de Apodanthera en forma provisoria.

Material adicional examinado. PERÚ. Cajamarca. Prov. Cajamarca: cerca de San Juan, camino de Tingo a San Miguel, carretera Chilete-Cajamarca, 1600-1700 m s.m., 10 Abr 1950, R. Ferreyra 7089 (CTES, MO, UMS, US). Huana-Huana, entre Magdalena y San Juan, ruta a la costa, 1950 m s.m., 11 Mar 1972, I. Sánchez Vega 863 (F). Abajo de Choropampa, sobre el margen de la carretera Cajamarca-Pacasmayo, 1550-1600 m s.m., 10 Mar 1986, I. Sánchez Vega 3995 (F, NY). Prov. Contumaza: Primera Agua (abajo de San Benito), 1000 m s.m., 4 Jun 1994, A. Sagástegui et al. 15387 (K, TEX). Prov. San Ignacio: Huarango, Mechinal, 05019'S 7843'W, 600 m s.m., 2 Feb 1996, J. Campos \& O. Días 2336 (USM). La Libertad. Prov. Otuzco: arriba de Plazapampa (Ruta Salpo-Samne), 1800 m s.m., 13 Mar 1995, S. Leiva G. 1725 (F, NY). Prov. Trujillo: Cerro Campana, 700 m s.m., 28 Ago 1978, A. Sagástegui A. \& C. Kobata 9218 (MO, NY). Cerro Campana, 450 m s.m., 10 Ago 1985 J. Mostacero L. et al. 1062 (K, MO). Cerro Campana, 400 m s.m., 18 Ago 1986, A. Sagástegui A. \& E. García 12973 (K, NY). Cerro Cabras, 300 m s.m., Ago 1950, A. López M. 486 (US). 


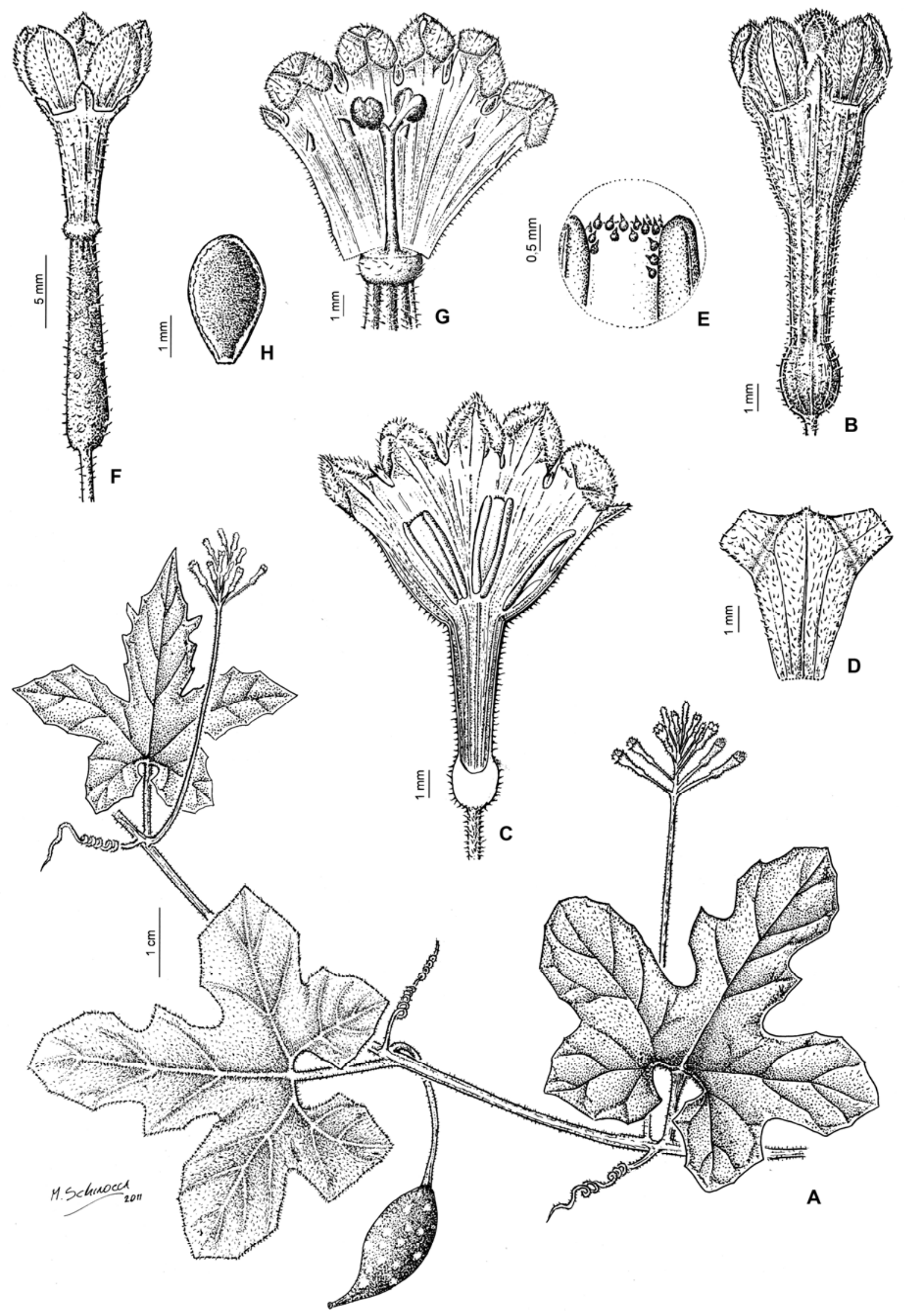

Figura 35. Apodanthera weberbauerii. A. Tallo con inflorescencias estaminadas y fruto. B. Flor estaminada, vista lateral. C. Flor estaminada, corte longitudinal. D. Pétalo lobulado. E. Tricomas glandulares ampuliformes del ápice del conectivo. F. Flor carpelada, vista lateral. G. Flor carpelada, con hipanto y perianto desplegados. H. Semilla. (Dibujo de M. Schinocca). A y H de Sagástegui 12973. B-G de Weberbauer 7485. 


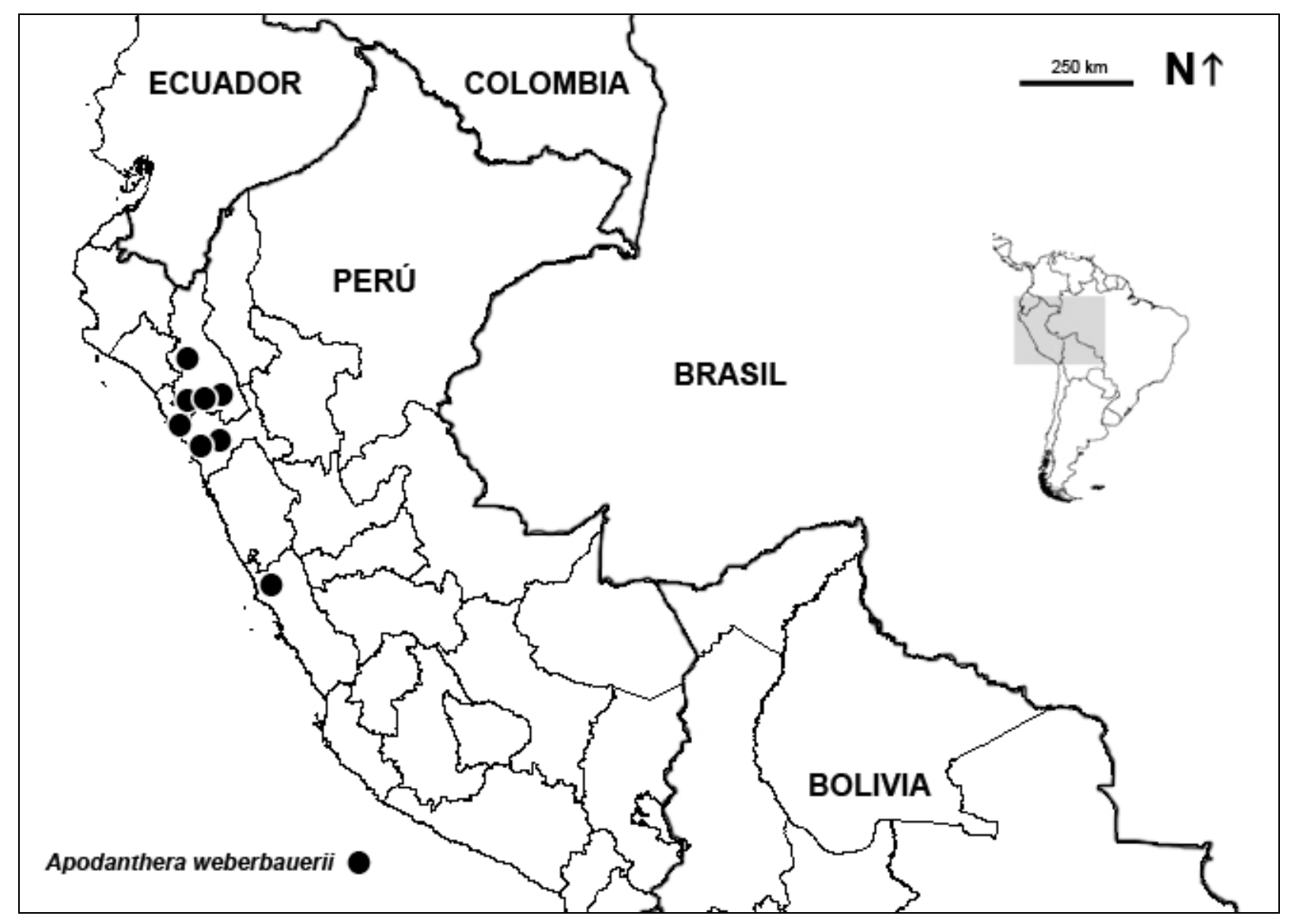

Figura 36. Distribución geográfica de Apodanthera weberbauerii.

82 


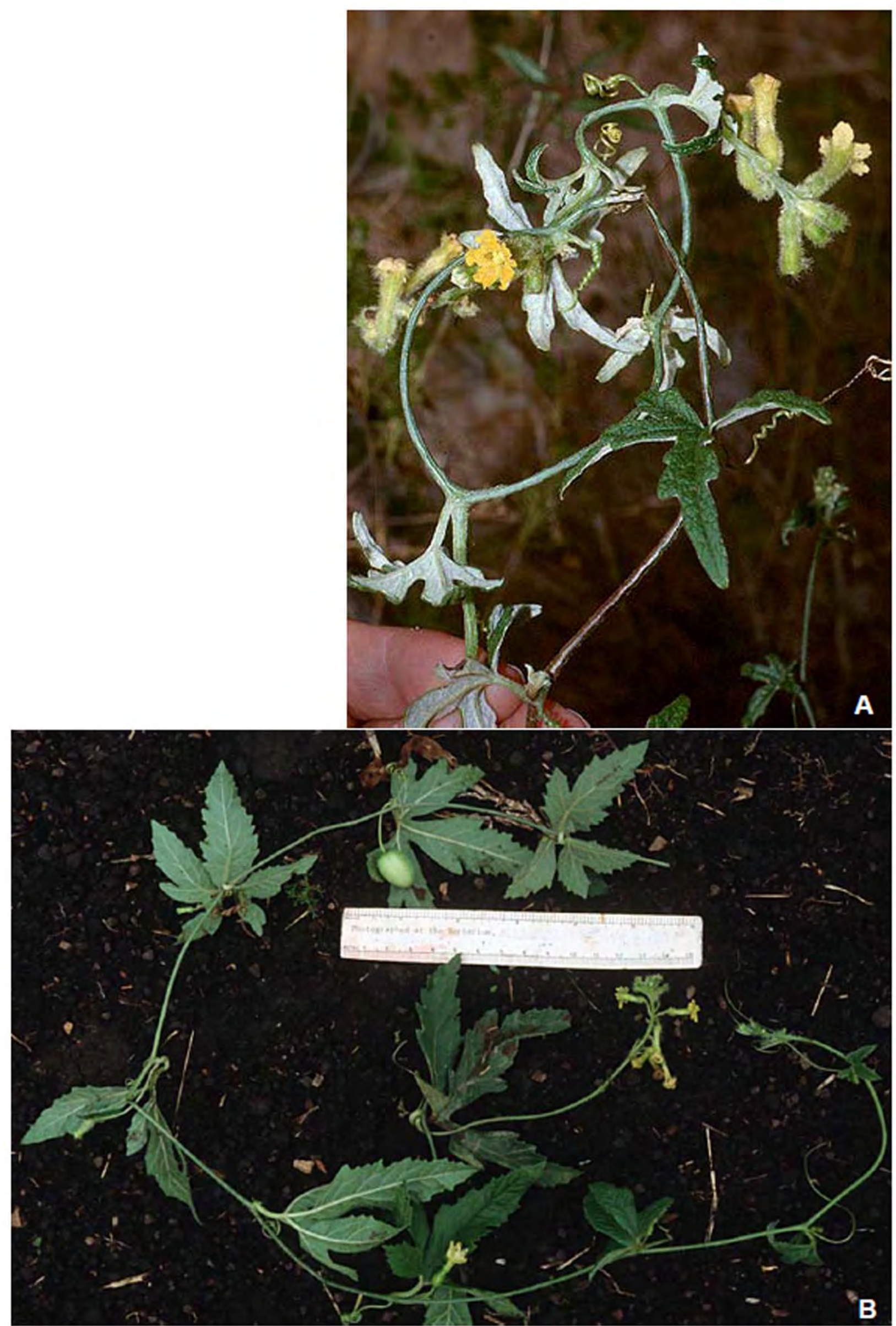

Figura 37. Apodanthera. A. Apodanthera mandonii, aspecto general, inflorescencias estaminadas (Foto: Heike Betz \& R. Foster, Field Museum). B. Apodanthera hirtella, aspecto general, inflorescencias estaminadas, carpeladas y fruto (Foto: Robert Knight, de Nee 36706). 


\section{Incerta saedis}

En este apartado se incluyen aquellas especies de posición genérica incierta, no consideradas como Apodanthera en el sentido estricto de esta tesis, pero que permanecen en este género hasta tanto se esclarezcan sus asignaciones genéricas.

1. Apodanthera anatuyana (Mart.Crov.) Pozner, Hickenia 2(40): 186. 1996. Basónimo: Melothria anatuyana Mart.Crov. Bol. Soc. Argent. Bot. 3: 98, f. 1. 1950, "Argentina: Santiago del Estero, Añatuya leg. Ragonese, Castiglioni y Piccinini 7140, i-1949 (BAB, Typus speciei)". TIPO. Argentina. Santiago del Estero, entre Añatuya y Colonia Dora, 29 Ene 1949, A. E. Ragonese et al. 7140 (holotipo, BAB!; isotipo, K-430958!). Figura 38.

Hierbas perennes, monoicas, zarcillosas, pubérulas, con tricomas glandulares simples, cortos, con célula apical subesférica, patentes, tanto en estructuras vegetativas como reproductivas; tallos anuales muy ramificados, gráciles, hasta de 1,5 $\mathrm{mm}$ de diámetro, notablemente estriados, esparcidamente pubérulos a grabrescentes; entrenudos hasta de $7,5 \mathrm{~cm}$ de largo. Pecíolos delgados, filiformes en hojas jóvenes, de $0,7-2,5 \mathrm{~cm}$ de largo; láminas de contorno anchamente ovado o subpentagonal, profundamente 5-lobadas o 5-sectadas, de 3,2-6,5 x 4-8 cm, base amplia y profundamente cordada, crasiúsculas, ligeramente discolores, escabroso-pubescente en ambas caras, con tricomas cónicos con corona de células accesorias muy notable, lóbulos angostamente elípticos, lanceolados a oblongos, de borde entero o paucidentado, con nervio central conspicuo, mucronados, el lóbulo central de 2-4,5 x 0,3-1,3 cm, los laterales similares, casi perpendiculares al central (los senos amplios, casi en ángulo recto), los lóbulos más basales notablemente menores, de disposición similar con respecto a los lóbulos contiguos. Zarcillos simples, filiformes, pubérulos, principalmente hacia la base. Inflorescencia estaminada de aspecto racemiforme, pedunculada, 4-12-flora, usualmente co-axilar con la inflorescencia carpelada; pedúnculo filiforme, algo flexuoso y ascendente, hasta de $3 \mathrm{~cm}$ de largo, pubérulo; pedicelos filiformes, de $3 \mathrm{~mm}$ de largo en flores abiertas, pubérulos. Flores estaminadas bracteadas, brácteas filiformes, agudas, de 0,5-0,8 $\mathrm{mm}$ de largo; hipanto campanulado, esparcidamente pubérulo, 10-nervio, de 1,2-2 mm de largo x 1,8-2,2 mm de ancho en el ápice, donde el hipanto está algo dilatado, la base ligeramente redondeada, interiormente el hipanto es villoso cerca de la fauce, en la zona de inserción de los estambres; sépalos subtriangulares, de 0,6-1 mm de largo, pubérulos hacia del ápice, interiormente glabros; pétalos ovadolanceolados, de 1,5-1,7 x 0,8-1,2 mm, ápice agudo, margen entero, amarillentos o amarillo verdoso, 3-nervios, fina y cortamente pubescentes en la cara dorsal, diminutamente pubérulos en la ventral; estambres 3, 2 ditécicos, uno monotécico, insertados cerca de la fauce del hipanto, resultando parcialmente exertos, opositipétalos; anteras subcuadradas, dorsifijas; filamento brevísimo, glabro; conectivo hialino, algo ensanchado, no extendido en el ápice, 
glabro; tecas ca. $1 \mathrm{~mm}$ de largo, botuliformes, subrectas; pistilodio ausente; nectario basal ausente 0 no evidente. Inflorescencia carpelada 1-flora, usualmente co-axilar con la inflorescencia estaminada; pedicelo grácil, pubérulo, breve, de 2-4 mm de largo, alargándose hasta ca. $10 \mathrm{~mm}$ en el fruto; hipanto cortamente subcilíndrico, de 0,8-1 mm de largo, algo ensanchado hacia el ápice y en la base, pubérulo exteriormente, con pubescencia profusa interiormente, cerca de la fauce, de tricomas eglandulares filiformes; cáliz y corola similares a los de las flores estaminadas; estaminodios 3(-4), diminutos, a veces anteriformes (como anteras reducidas), a veces dos de ellos algo aproximados entre sí de a pares o en posiciones intermedias, insertados cerca de la fauce del hipanto; ovario elipsoide o fusiforme, de 2,5-3 x ca. $1 \mathrm{~mm}$, densamente pubérulo, 2-placentífero, pauciovulado; estilo columnar, glabro, breve, 1-1,5 mm de largo, con 2 ramas brevísimas; estigmas 2-lobulados, los lóbulos de superficie papilosa. Fruto esferoidal o anchamente elipsoide, de 11-13 x 7-8 mm, rojo cuando maduro, pauciseminado, pubérulo a glabrescente, cortamente rostrado. Semillas 4-8, anchamente obovoides, de 5-7 x 4-5 mm, negruzcas, comprimidas, de superfice irregular, eponjosa cuando húmeda.

Distribución geográfica y hábitat. Habita en el Chaco occidedental del sur de Bolivia (Chuquisaca y Santa Cruz de la Sierra) y norte de la Argentina (Formosa, Salta y Santiago del Estero), entre los 150 y 400 m s.m. (Figura 39). Crece sobre la vegetación leñosa del monte xerofítico o en palmares.

Nombre vulgar. "To' cyus" [Maranta \& Arenas 311 (MO)].

Etimología. El epíteto específico hace referencia a la localidad de colección del ejemplar tipo, Añatuya, en la provincia de Santiago del Estero, Argentina.

Fenología. Florece y fructifica en los meses de verano y hasta comienzos del otoño.

Observación 1. Martínez Crovetto (1950) colocó a la especie dentro del género Melothria sobre la base de sus anteras subcuadradas, aunque paralelamente afirma que la especie difiere de los demás miembros de este género por sus ovarios 2-placentíferos, con 2 ramas estilares (vs. 3-placentíferos y con 3 ramas estilares en Melothria). Posteriormente, Jeffrey (1978) indicó que debería ser excluida de Melothria por carecer de conectivos ciliados. Finalmente, Pozner (1996) la transfirió a Apodanthera, aunque con dudas, por tratarse del género dentro del cual mejor se ajustaba la especie. Apodanthera anatuyana difiere de Apodanthera, según la circunscripción propuesta en esta tesis, por presentar zarcillos simples, gráciles, flores estaminadas bracteadas, diminutas, campanuladas, con hipanto villoso en la fauce, frutos pauciseminados y semillas de superficie rugoso-espojosa cuando húmedas. 

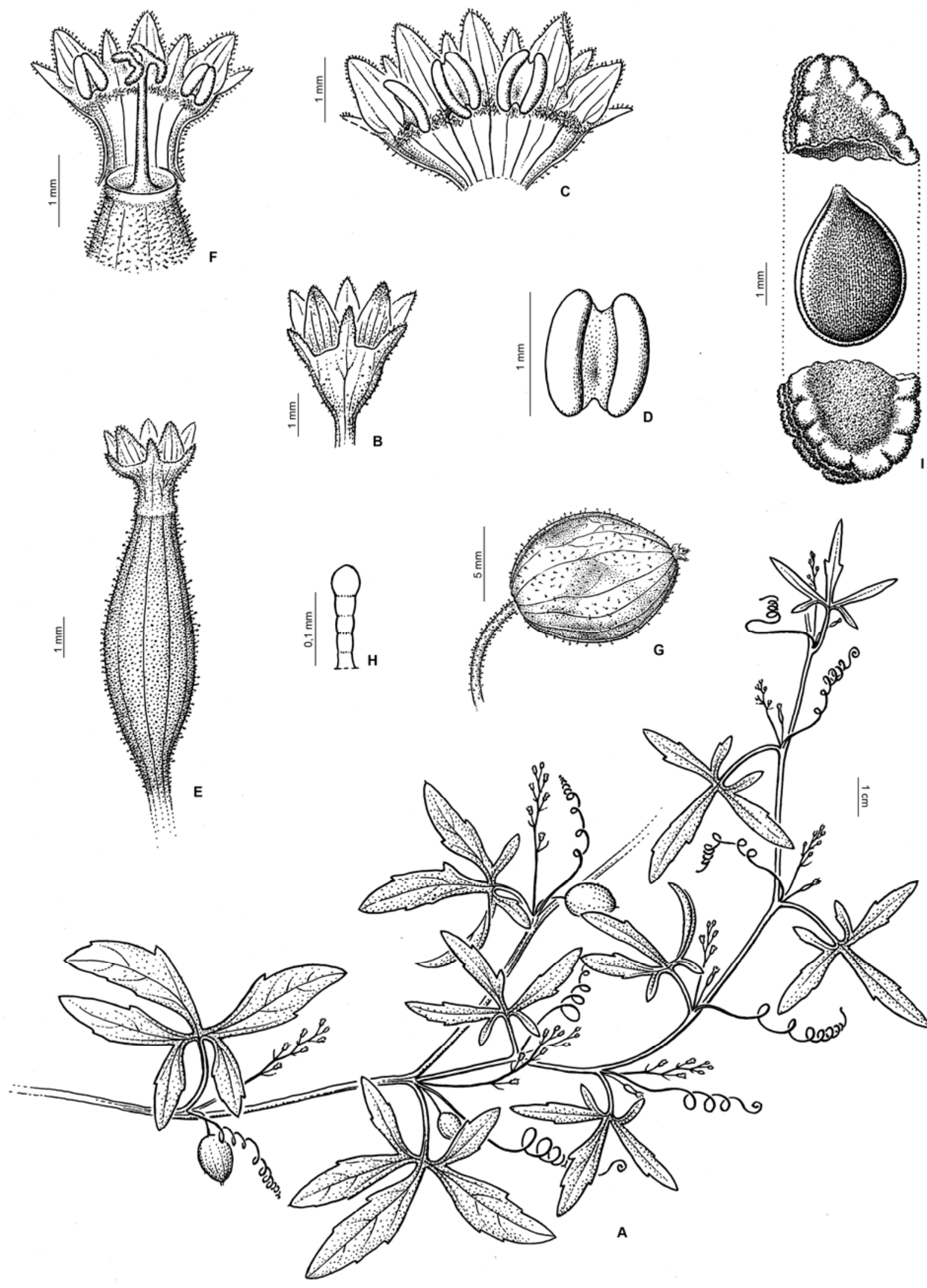

Figura 38. Apodanthera anatuyana. A. Tallo con inflorescencias estaminadas, carpeladas y frutos. B. Flor estaminada, vista lateral. C. Flor estaminada desplegada, vista interna. D. Antera. E. Flor carpelada, vista lateral. F. Flor carpelada, con hipanto y perianto desplegados. G. Fruto. H. Tricoma glandular simple, capitado. I. Semilla (seccionada) y embrión. (Dibujo de F. Rojas, Instituto Darwinion). A de Fuentes 2261. B-I de Burkart 20212. 


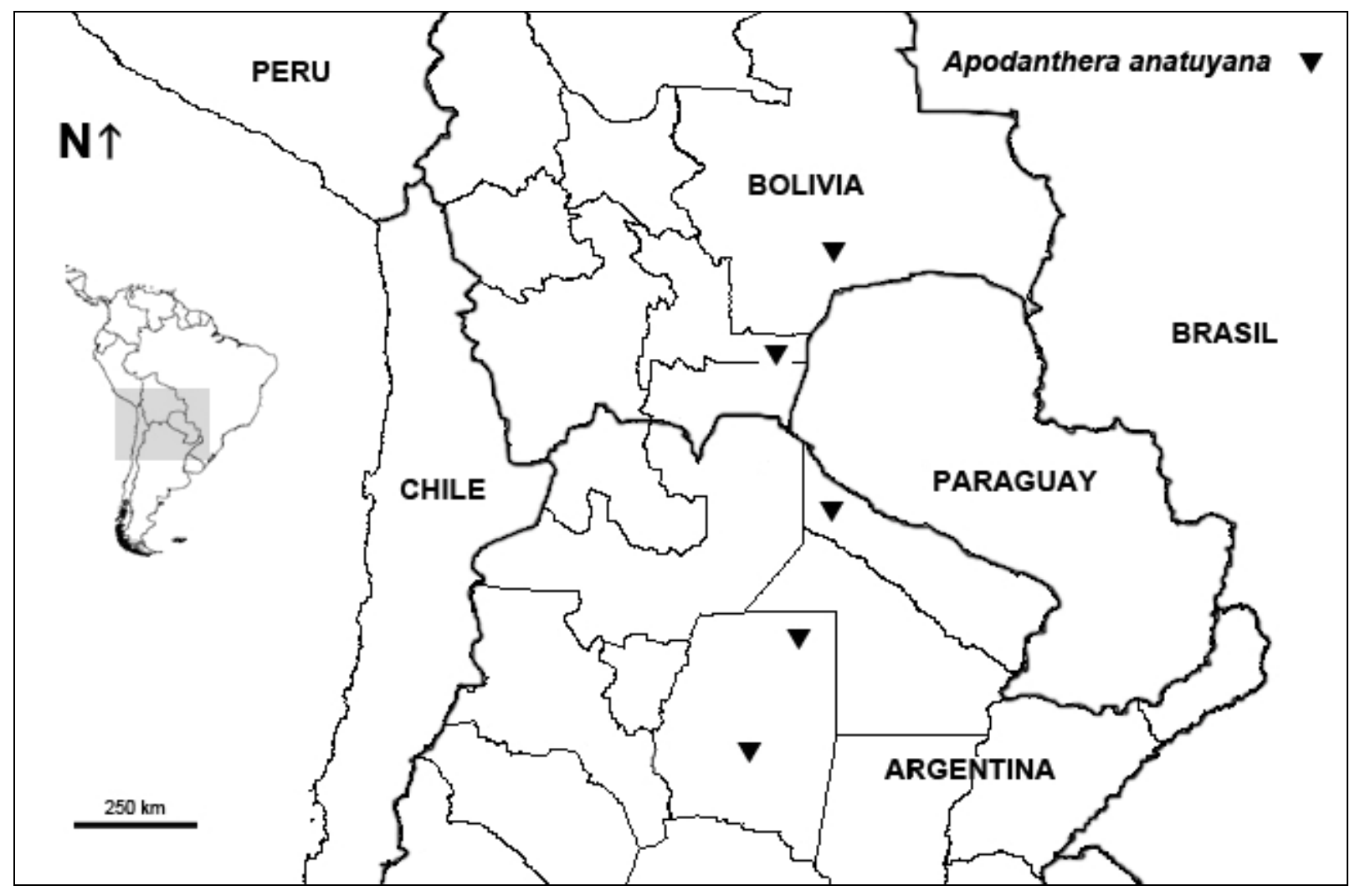

Figura 39. Distribución geográfica de Apodanthera anatuyana.

Observación 2. Apodanthera anatuyana es morfológicamente muy similar a A. ulei, especie de zonas húmedas del sudeste de Brasil, tal como se evidencia en el análisis filogenético obtenido en esta tesis, en el que ambas especies se agrupan. Se las puede distinguir por los zarcillos (simples en $A$. anatuyana, 2-fidos en $A$. ulei) y por las semillas (fuertemente comprimidas y rugoso-esponjosas en $A$. anatuyana, lisas y apenas comprimidas en $A$. ulei). La posición y relación de estas dos especies frente a los demás géneros de la tribu Coniadreae no puede precisarse y por ese motivo se las incluye en Incerta saedis.

Observación 3. Se ha indicado que las plantas desprenden olor fétido [Fuentes 2261 (CTES)].

Material adicional examinado. ARGENTINA. Formosa. Dpto. Matacaos: $6 \mathrm{~km}$ alrededores de Ing. G. N. Juárez, 28 Ene 1987, P. Arenas 3249 (BACP-3487 en BA). Ing. Juárez, 12 Ene 1957, A. Burkart 20121 (SI). Salta. Dpto. Rivadavia: Los Blancos, cañada a 3 km del pueblo, hacia el W, 26 Ene 1983, A. Maranta \& Arenas 311 (MO). Santiago del Estero. Dpto. Copo: Parque Nacional Copo; $50 \mathrm{~km}$ al NW de Pampa de los Guanacos, en picada de prospección petrolífera, $25^{\circ}$ 53' 41,9" S, 610 55' 05,3'W, 160 m s.m., 31 Ene 1999, J. Tolaba et al. 1349 (MCNS). BOLIVIA. Chuquisaca. Prov. Luis Calvo: $4 \mathrm{~km} \mathrm{~W}$ del Puesto 15 de Agosto, rumbo a Edén Chaqueño, 205'S, 62³3'W, 380 m s.m., 8 Abr 1993, C. Saravia Toledo et al. 11514 (CTES). 
Santa Cruz. Prov. Cordillera: Parque Nacional Kaa-Iya del Gran Chaco, Palmar de las Islas, 19²5'56"S, 60³2'24" W, 270 m s.m., 11 Feb 1998, A. Fuentes \& G. Navarro 2261 (CTES).

2. Apodanthera biflora Cogn., Mém. Couronnes Autres Mém. Acad. Roy. Sci. Belgique 27: 43. 1877. "In Ecuadore: "Chanduy, in litore maris Pacifici, aprili 1862" (Spruce, nº 6462, in hb. Kew, Brit. Mus. DC, Mus. Paris., Hort. bot. Petrop.)". TIPO. Ecuador. Chanduy in littore maris Pacifici, Abr 1862, herba reptans scandensve subramosa 6-pedalis valde heterophylla, flores flavidi, R. Spruce 6462 (lectotipo, K-6238!, aquí designado; isolectotipos, BM-906038!, GH-31802!, K-6237!; P-257367!). Figuras 40 y 46A-D.

Hierbas perennes, diclino-monoicas, zarcillosas; raíces tuberosas, hasta de $20 \times 15 \mathrm{~cm}$; tallos anuales hasta de $4 \mathrm{~m}$ de largo y 1-2,5 mm de diámetro, estriados longitudinalmente, glabrescentes; entrenudos de 2,8-12,6 cm de largo, a veces en los extremos de las ramas orientados en "zig-zag". Pecíolos de 1,8-6 x 1-2 mm, esparcidamente híspidos, con tricomas eglandulares cónicos, de base unicelular, robustos, con célula apical aguda; láminas cordiformes, de 5-11,5 x 5,2-12 cm, apiculadas, margen entero, remotamente denticulado (hidátodos), raramente 3-5-lobadas, con lóbulos angostamente elípticos o lanceolados, de ápice redondeado, mucronado o apiculado, senos redondeados, margen irregularmente dentado o sinuado, de consistencia membranácea, ligeramente discolores, verde más pálido en la cara abaxial, la cara adaxial es tenuemente punteado-pubescente o glabrescente, la abaxial escabrosa, con tricomas eglandulares cónicos, cortos y robustos, erectos o ligeramente curvados, con corona basal de células accesorias (que confieren escabrosidad al caer las células apicales de éstos). Zarcillos simples, gráciles, glabrescentes o glabros. Inflorescencia estaminada 1-2-flora (excepcionalmete hasta 7-flora y de aspecto racemiforme), hasta de 20,5 $\mathrm{cm}$ de largo, largamente peduculada; pedúnculo ascendente, que alcanza hasta $14,5 \mathrm{~cm}$ de largo, estriado longitudinalmente, esparcidamente híspido (con tricomas eglandulares filiformes y cónicos, agudos) a glabrescente; pedicelos ascendenes, de 1,5-5 cm de largo, glabrescentes a esparcidamente híspidos, con tricomas similares a los del pedúnculo, más abundantemente hacia el ápice. Flores estaminadas a menudo bracteadas; bráctea linear a lanceolada, fácilmente caduca, hasta de $8 \mathrm{~mm}$ de largo, margen dentado; hipanto subcilíndricoinfundibuliforme, de (10-)12-17 mm de largo x (4-)6-8 mm de ancho en la parte superior y (2-)3$5 \mathrm{~mm}$ en el medio, base atenuada o redondeada, con nectario mensenquemático cupuliforme, sólido en la base, exteriormente el hipanto es largamente lanoso (muy notablemente en pimpollos, glabrescente al desarrollarse la flor) con tricomas eglandulares filiformes, adpresoascendentes, algunos con célula apical subulada, otros algo geniculada, interiormente el hipanto es villoso a media altura del tubo (como una "banda tricomatosa"), por debajo de las anteras; sépalos linaear-subulados, de $8-13 \mathrm{~mm}$ de largo x 1-2 mm de ancho en la base, 
externamente lanosos como el hipanto, más profusamente hacia la base y disminuyendo paulatinamente hacia el ápice, el que resulta glabrescente; pétalos subiguales, oblongolanceolados a elípticos, de 2,4-3,5 x 0,8-2,1 cm, amarillos, ápice agudo, cortamente acuminado, margen entero o tenuemente crenulado, con (3-)5(-7) nervios más notables, glabrescentes en la cara dorsal, sólo con pilosidad fina sobre los nervios, con abundantes tricomas glandulares moruliformes en la cara ventral; estambres 3, dos ditécicos y 1 monotécico, insertados cerca de la fauce y resultando su porción superior exerta; anteras dorsifijas; filamento breve, glabro; conectivo glabro, apenas más ancho en el ápice, a veces escotado en ápice y base; tecas subiguales, ca. $5 \mathrm{~mm}$ de largo, rectas o apenas arqueadas en ápice y base. Inflorescencia carpelada 1-flora, usualmente en nudos distintos a los que portan las inflorescencias estaminadas; pedicelo ca. $3 \mathrm{~cm}$ de largo, alargándose hasta $8 \mathrm{~cm}$ en el fruto, finamente estriado, glabrescente o esparcidamente hispídulo, con tricomas eglandulares simples, filiformes, largos; flor carpelada ebracteada; hipanto sub-cilíndrico, de 5-7,5 mm de largo x 2-2,5 mm de ancho en la base y 3-4,5 $\mathrm{mm}$ de ancho hacia el ápice, exteriormente hispídulo, interiormente pubescente cerca de la fauce, hacia la base de los pétalos; sépalos linear-subulados de $8 \mathrm{~mm}$ de largo, externamente híspidos, más ralamente hacia el ápice, glabros internamente; corola similar a la de las flores estaminadas pero los pétalos angostamente elípticos y menores, ca. $2 \mathrm{~cm}$ x $6 \mathrm{~mm}$, 7-nervios; estaminodios (3-)5, diminutos, subiguales, mameliformes, insertados cerca de la fauce del hipanto, a veces aproximados de a pares; ovario angostamente elipsoide, ca. $1 \mathrm{~cm} \times 3,5 \mathrm{~mm}$, más angosto hacia el ápice, hispídulo, principalmente hacia la base, tornándose luego glabrescente, 3-placentífero; estilo columnar glabro, hasta de $7 \mathrm{~mm}$ de largo, con 3 ramas breves; estigmas profundamente 2lobulados, lóbulos oblongoides de superficie papilosa. Fruto carnoso, indehiscente, esferoidal o anchamente elipsoide, de 2,2-6 × 2-4 cm, rostrado, rostro de 6-8 mm de largo, liso, con bandas alternas de color verde claro y oscuro. Semillas ovoides, comprimidas, de 5-6 x 3,5-4,5 mm y ca. $1,5 \mathrm{~mm}$ de espesor, lisas, de color castaño-pajizo, apenas marginadas y de color cremoso en el borde sagital.

Nombres vulgares y usos. "Yuca de monte" (Ferreyra 1983); "yucca de monte" [Ferreyra 5888 (USM), Ferreyra 9065 (USM), Haught 141(BM, F, NY, US), Weberbauer 5944 (F, GH, NY, US)]. Se ha indicado que sus raíces tuberosas son comestibles luego de ser cocidas [Ferreyra 5888, Haught s.n. (F, US)]. Existen proyectos en curso de domesticación y conservación de esta especie, tendientes a evaluar sus propiedades nutricionales y valor agroindustrial (W. González, Universidad Peruana Cayetano Heredia).

Distribución geográfica y hábitat. Habita en regiones costeras de Ecuador y Perú, principalmente en el bosque seco del norte de Perú (Figura 41), en la denominada formación del "algarrobal", un ecosistema subotropical situado entre Trujillo y Tumbes, dominado por 
Prosopis pallida (Humb. \& Bonpl. ex Willd.) Kunth, el "algarrobo", junto con otras especies arbóreas (Ferreyra 1983). En los campos abiertos del "algarrobal" se desarrolla un herbazal graminoso junto con algunas especies volubles de rápido crecimiento que cubren árboles y arbustos. Según el Mapa ecológico del Perú (ONERN 1976), corresponde a un "matorraldesértico-tropical". También se ha reportado la presencia de Apodanthera biflora en la comunidad de "manglar", una formación halófila del extremo norte de la costa peruana, conformada por un bosque denso y un herbazal efímero que cubre los lugares expuestos y la vegetación leñosa (Ferreyra 1983). Florece y fructifica de febrero a mayo.

Etimología. El epíteto específico alude al número de flores en la inflorescencia estaminada, usualmente en número de 2 (del latín "bi" = bi o dos y "flora" = de flores).

Fenología. Se ha indicado que el crecimiento de los tallos anuales tiene lugar sólo luego de lluvias intensas, usualmente a intervalos de varios años [Haught s.n. (F)].

Observación 1. Apodanthera bilfora se aparta de Apodanthera s. str. por los siguientes caracteres: flor estaminada con pétalos vistosos, de 1-2 cm de largo; hipanto de la flor estaminada con una banda tricomatosa en su interior, a media altura del tubo; inflorescencia estaminada a menudo 1-2-flora; hipanto de la flor carpelada pubescente cerca de la fauce; hojas a menudo acorazonadas. En la filogenia combinada obtenida en esta tesis $A$. biflora resulta de posición incierta; entre las filogenias molecular y morfológica, por su parte, no hubo congruencia respecto a su posición: en la primera se agrupa con algunas de las especies brasileras de Apodanthera sección Pseudoapodanthera + Doyerea, en la segunda con $A$. cinerea y con Apodanthera s. str.

Observación 2. En la descripción original de la especie, A. Cogniaux indicó la existencia de duplicados del ejemplar tipo en diversos herbarios europeos (sintipos). En este trabajo se designa como lectotipo aquél depositado en el herbario de Kew $(K)$, con código de barras número 6238. Este ejemplar posee la etiqueta original de Spruce, identificación de puño y letra de A. Cogniaux, ilustración con análisis florales del autor, dos ramas que ilustran, cada una de ellas, la variación de las hojas (una entera, la otra lobada). No se han localizado duplicados de esta colección en el herbario BR, donde trabajaba Cogniaux.

Observacion 3. Se ha indicado que los tallos emanan un olor desagradable como el de "Stinking gourd" (Cucurbita foetidissima Kunth) del sur de Estados Unidos de América [Haught s.n. (F)]. La floración se da hacia fines del verano y comienzos del otroño, entre los meses de marzo y abril. 
Material adicional examinado. ECUADOR. Guayas. North of Punta Carnera, $2^{\circ} 19^{\prime} \mathrm{S}, 80^{\circ} 55^{\prime} \mathrm{W}$, 7 Mar 1941, H. K. Svenson 11296 (GH). PERÚ. Lambayeque. Prov. Lambayeque: entre Jayanca y Motupe, 100-150 m s.m, 18 Abr 1953, R. Ferreyra 9065 (USM). Piura. Prov. Piura: Despoblado de Piura, 200-250 m s.m., 20 Abr 1953, R. Ferreyra 9107 (F, USM). Between Piura and Ñomala, 100-250 m s.m., Mar 1912, A. Weberbauer 5944 (F, GH, NY, US). 17 km Sur de Piura, 100-150 m s.m., 16 Abr 1949, R. Ferreyra 5888 (USM). Prov. Talara: Negritos, 1928, O. L. Haught s.n., F.P.I. 88329 (F, US). Negritos, 4 miles north of La Bua, 17 Mar 1929, in small watercourses on the "Zablazo", O. L. Haught 141 (BM, F, NY, US).

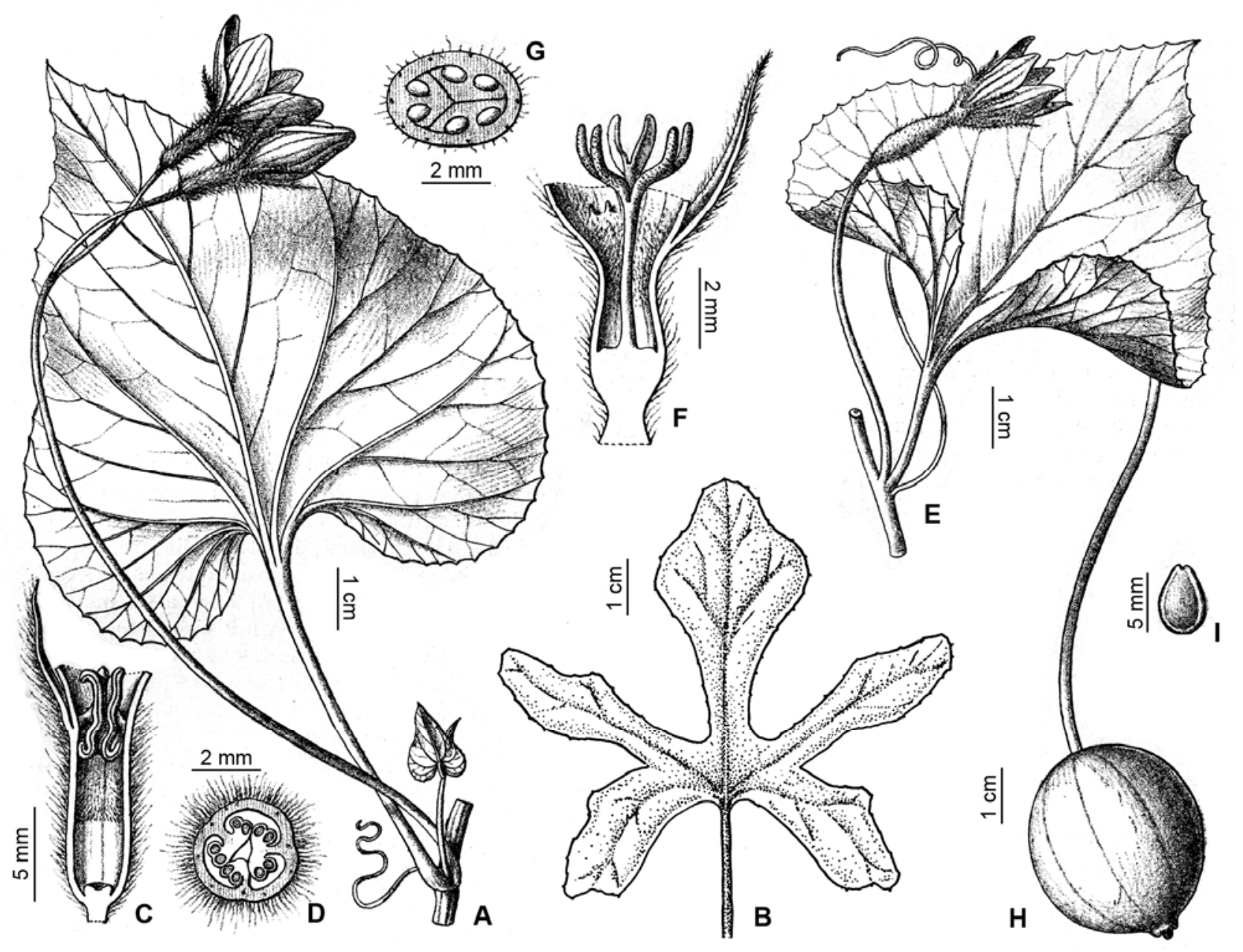

Figura 40. Apodanthera biflora. A. Nudo con hoja cordiforme típica e inflorescencia estaminada 2-flora. B. Hoja profundamente lobada. C. Flor estaminada, corte longitudinal. D. Flor estaminada, corte transversal. E. Nudo con flor carpelada. F. Flor carpelada, corte longitudianal del hipanto y ápice del ovario. G. Ovario, corte transversal. H. Fruto. I. Semilla (Tomado de Cogniaux, 1916; B, dibujo de M. Schinocca, de Haught 141b). 


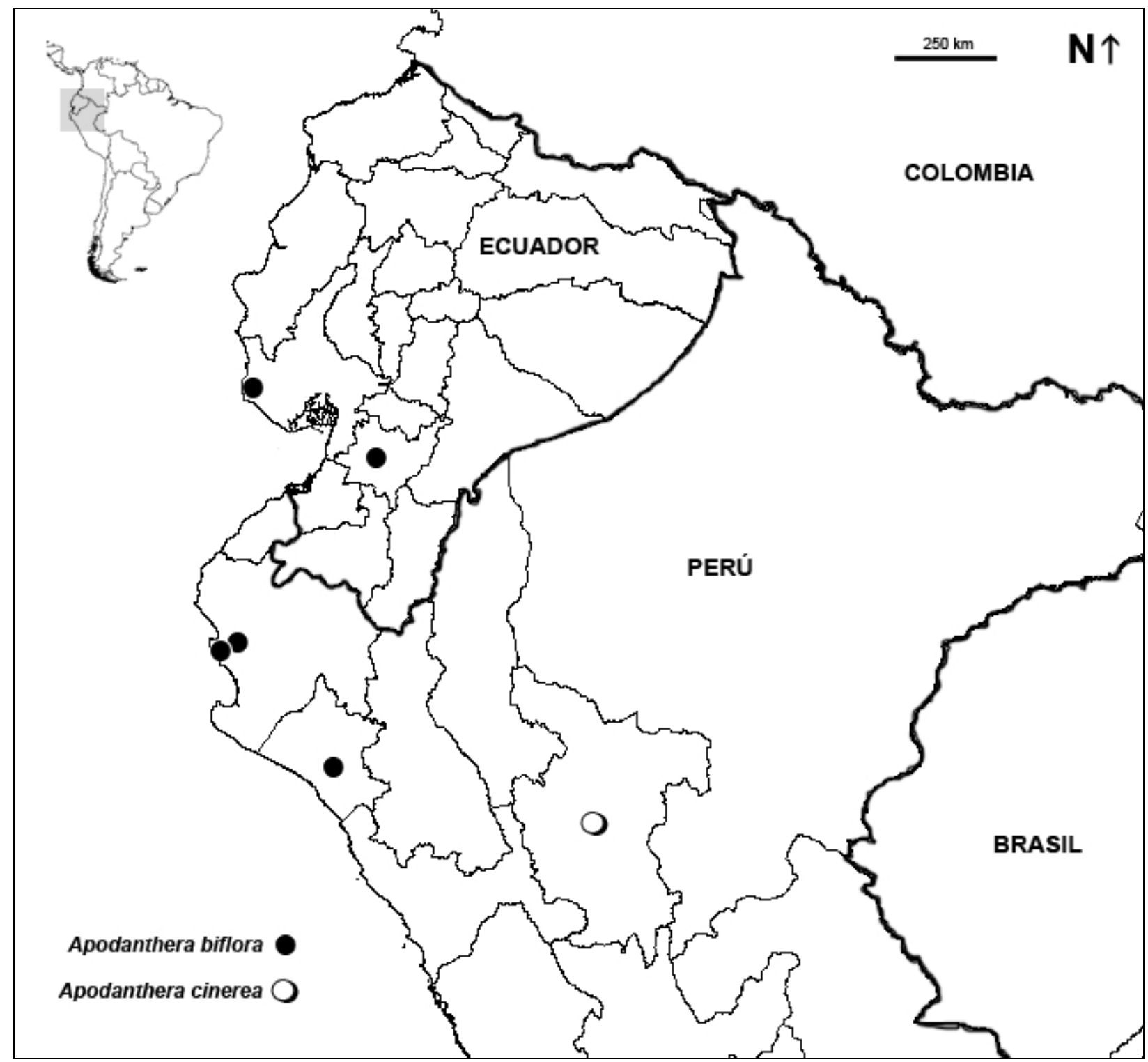

Figura 41. Distribución geográfica de Apodanthera biflora y A. cinerea.

3. Apodanthera cinerea Cogn., Pflanzenr. 66(IV. 275. I): 59. 1916, "Subäquatoriale andinae Provinz: Peru: Dept. Loreto, Salinas de Pilluana, Huallaga (E. Ule n. 6759. - Herb. Berlin)". TIPO. Perú. Departamento Loreto. Kletterpflanze, BI. gelb, Salinas de Pilluana, Huallaga, Ene 1903, E. Ule 6759 (lectotipo, K-430963!, aquí designado; isolectotipos, BR841 192!, G!, HBG-506435!, L-602750!). Figura 42.

Apodanthera cinerea Cogn., Bot. Jahrb. Syst. 40: 416. 1908, nom. nud.

Hierbas perennes, diclino-monoicas, zarcillosas; tallos anuales gráciles, hasta de 1,7 mm de diámetro, notoriamente estriados longitudinalmente, híspidos, con abundantes tricomas eglandulares filiformes, patentes o algo adpresos, y con otros tricomas más robustos, cónicos, 
de base multicelular, de 0,5-1 $\mathrm{mm}$ de largo, notables a simple vista (como dentículos); entrenudos de 4,5-7,5 cm de largo. Pecíolos robustos, algo aplanados, de 2-3,3 cm de largo x ca. $1,5 \mathrm{~mm}$ de diámetro, estriados longitudinalmente, con indumento similar al de los tallos pero más profuso; láminas anchamente ovadas o subpentagonales, notablemente 3-5-lobadas, de 3,5-6 x 3,7-6 cm, base profunda y ampliamente cordada, margen irregularmente dentado, remotamente denticulado con hidátodos notables, membranácea, de color verde, ligeramente discolores, ambas caras densamente tomentosas, la abaxial más profusamente, resultando algo más canescente que la adaxial, con abundantes tricomas cónicos de base unicelular, agudos, adpresos; lóbulos ovado-elípticos, el central de 2,5-3,5 x 1,2-2 mm, los laterales algo menores, de ápice agudo, los senos muy amplios. Zarcillos simples, finamente estriados, hispídulos. Inflorescencia estaminada 8-23-flora, largamente pedunculada, de aspecto inicialmente subumbeliforme, luego racemiforme, a medida que se desarrolla el eje entre las flores; pedúnculo ascendente, de $6-10 \mathrm{~cm}$ de largo, estriado longitudinalmente, hirsutotomentoso, con abundantes tricomas eglandulares filiformes, algo adpresos; pedicelos hasta $1,5 \mathrm{~cm}$ de largo, hirsuto-tomentosos, persistentes y algo arqueados luego de caida la flor. Flores estaminadas ebracteadas; hipanto acampanado, de 1,7-4 mm de largo y 1,4-4 mm de ancho en el ápice, la base se prolonga en una invaginación tubular muy angosta, de 1,5-3,5 $\mathrm{mm}$ de largo y ancho similar al del pedicelo, exteriormente el hipanto es hirsuto-tomentoso, como el pedicelo, interiormente es glabro; sépalos subtriangulares, 1,5-2,5 mm de largo, con indumento como el hipanto; pétalos obovado-elípticos, con los bordes algo involutos, 2-3 x 2-3 $\mathrm{mm}$, ápice redondeado, amarillos, con 3 nervios principales, corta y densamente afelpadovillosos en la cara dorsal, pilósulos en la ventral; estambres 3, 2 ditécicos y 1 monotécico, insertados en la mitad superior del hipanto, insertos; anteras dorsifijas, elipsoides; filamento muy breve, glabro; conectivo algo ensanchado, a menudo con escotaduras muy profundas en ápice y base, glabro; tecas alantoides, ligeramente arqueadas, ca. 1,5 mm de largo; pistilodio hipantial en la invaginación basal del hipanto, con 2 crestas diminutas, redondeadas. Inflorescencia carpelada desconocida. Flor carpelada desconocida. Fruto solitario, cortamente pedicelado (pedicelo de 5-10 mm de largo), carnoso, indehiscente, anchamente elipsoide, de 2$3 \times 1,6-2,1 \mathrm{~cm}$, redondeado en la base, atenuado hacia el ápice, éste rostrado, de superficie lisa, densamente hispídulo. Semillas horizontales, numerosas, fuertemente comprimidas, ovado-elipsoides, ca. 3,5 × 2 mm, de superficie irregular, rugoso, esponjosa cuando húmeda.

Distribución geográfica y hábitat. Hasta el momento la especie sólo es conocida por el ejemplar tipo, coleccionado en las formaciones calcáreas y salinas situadas al norte de la localidad de Pilluana (Figura 41), en el departamento San Martín, en la cuenca superior del río Amazonas, a unos 300 m s.m. 
Etimología. El epíteto específico proviene del latín "cinereus" = ceniciento, de color de la ceniza, en alución al color que el indumento cano-tomentoso le confiere a las hojas.
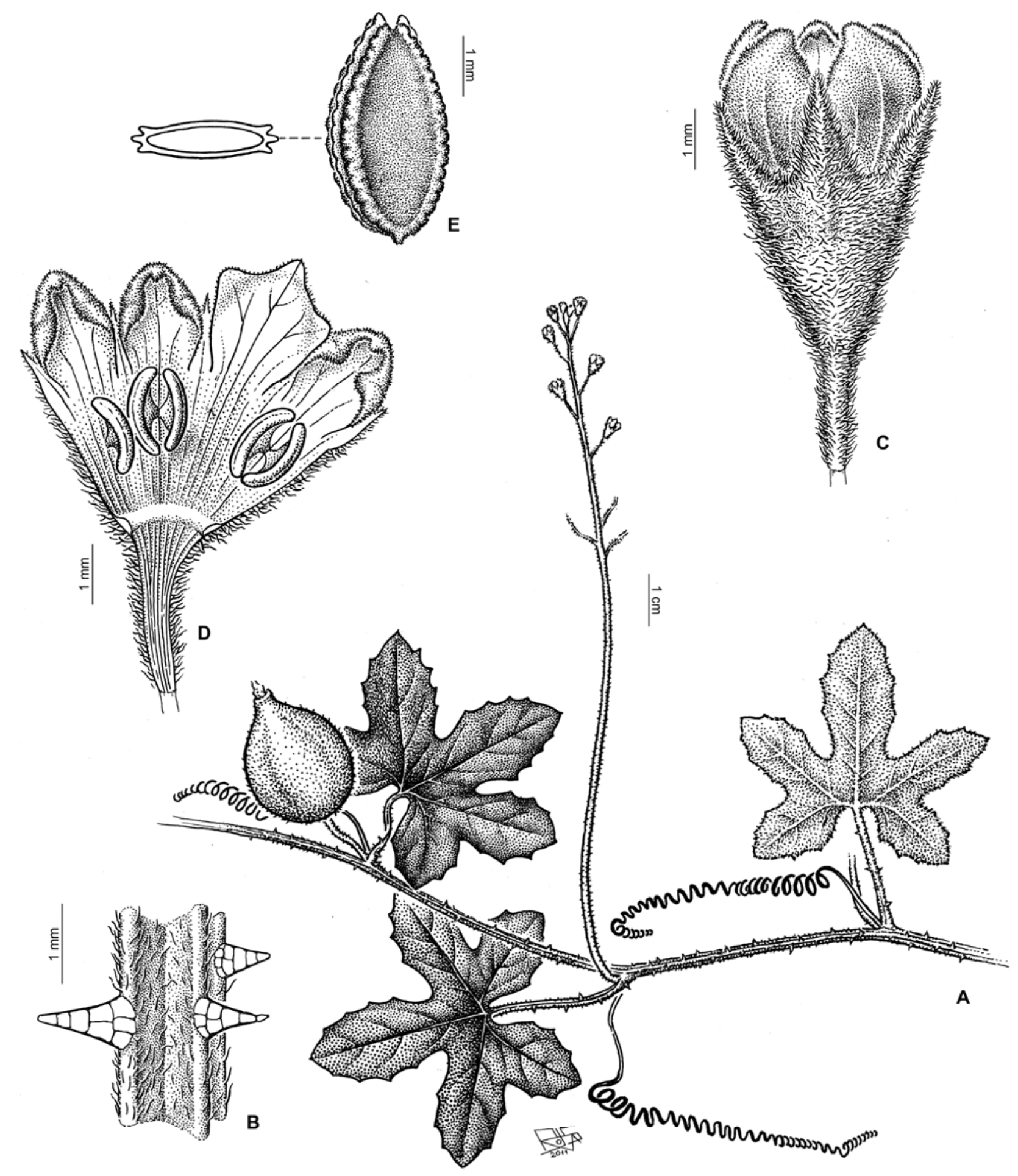

Figura 42. Apodanthera cinerea. A. Tallo con inflorescencia estaminada y fruto. B. Tallo, detalle del indumento. C. Flor estaminada, vista lateral. D. Flor estaminada desplegada, vista interna. E. Semilla, con esquema de corte transversal. (Dibujo de F. Rojas, Instituto Darwinion). A-E de Ule 6759; el fruto se ilustró a partir de la fotografía de la serie $F$, neg. $n^{\circ} 8951$ ). 
Fenología. Coleccionada en flor y fruto durante el mes de enero.

Observación 1. Apodanthera cinerea se aparta de las demás especies aquí tratadas por la presencia de un pistilodio hipantial, cilíndrico, en la base de las flores estaminadas. Martínez Crovetto, en sus notas inéditas, sugiere colocar al taxón en un género independiente, al que denominó tentativamente Anthopodus. La filogenia morfológica obtenida durante esta tesis ubica al taxón por fuera de Apodanthera s. str., en la combinada, en cambio, su posición queda sin resolución. Es necesario realizar nuevos estudios morfológicos (principalmente de las flores carpeladas y el fruto) y obtener mayor evidencia molecular para corroborar la escisión de Apodanthera y precisar su posición dentro de Cucurbitaceae. El único material disponible de esta especie (tipo) carece de flores carpeladas; por este motivo, no fueron descriptas por Cogniaux en el protólogo ni tampoco aquí. Consecuentemente, la asignación genérica de este taxón resulta muy dificultosa.

Observación 2. El ejemplar tipo en el herbario de Berlín se ha destruido (sólo se conserva del mismo la foto de la serie del Field Museum $n^{\circ}$ 8951). Por este motivo, se ha designado como lectotipo al duplicado en el herbario de Kew (código de barras 430963), de acuerdo con lo estipulado en el CINB (Arts. 9.9 y 9.10). Se trata de un ejemplar completo, que se ajusta al protólogo y que ha sido estudiado exhaustivamente por el autor de esta tesis. En el herbario de Bruselas (BR), institución en la que trabajaba el autor del binomio, sólo existe un fragmento de una hoja, que resulta insuficiente para caracterizar a la especie.

4. Apodanthera laciniosa (Schltdl.) Cogn., Mém. Couronnes Autres Mém. Acad. Roy. Sci. Belgique 27: 39. 1877. Basónimo: Anguria laciniosa Schltdl., Linnaea 24: 755. 1851. "Brasilia meridionalis (Sellow legit). Specimen ab Humboldtio cum Kunthio communicatum in herbarium regium transiit". TIPO. [Brasil] Brasilia meridionalis, Sello 4307 (lectotipo, GH-31804!, aquí designado; isolectotipo, BR-8411949). Figuras 43 y $46 \mathrm{E}-\mathrm{G}$.

Hierbas perennes, diclino-monoicas, zarcillosas; tallos anuales hasta de 2,5 mm de diámetro, estriados longitudinalmente, glabrescentes o esparcidamente hírtulos (más profusamente cerca de los nudos), con tricomas usualmente glandulares, simples, capitados; entrenudos de (5-)9$19 \mathrm{~cm}$ de largo. Pecíolos de 7-25 x 1-2 mm, densamente hirsutos; láminas de contorno anchamente ovado, profundamente 5-7(-9)-lobadas (excepcionalmente se observa dimorfismo foliar, en una misma rama pueden crecer también hojas enteras, cordiformes), de 8-20,8 x 8,5$20,2 \mathrm{~cm}$, base ampliamente cordada, membranáceas, discolores, cara adaxial verde, cara abaxial verde grisáceo, ligeramente tomentosa en ambas caras, con tricomas eglandulares cónicos de base unicelular, adpresos, algunos finos, otros más robustos, más profusos en la 
cara abaxial y sobre los nervios; lóbulos angostamente elípticos, lanceolados o linear lanceolados, de 5,5-13,5 x ca. 1-3,5 cm, los laterales notablemente menores, ápice mucronulado, margen notable e irregularmente dentado, remotamente denticulado, con hidátodos triangulares, ca. 0,5 mm de largo, blanquecinos. Zarcillos compuestos, 2-fidos (raramente 3-fidos), portazarcillos más o menos rectos, finamente estriados, glabrescentes o glabros, hasta de $4 \mathrm{~cm}$ de largo. Inflorescencia estaminada racemiforme, 5-23-flora, hasta de $20 \mathrm{~cm}$ de largo, largamente peduculada; pedúnculo ascendente, hasta de $13 \mathrm{~cm}$ de largo, estriado longitudinalmente, escasa a densamente hirsuto; pedicelos filiformes, ascendenes o algo recurvos, de 3-18 mm de largo, persistentes, hirsuto-tomentosos. Flores estaminadas usualmente bracteadas; bráctea linear o linear-lanceolada, de margen entero, fácilmente caduca, de 2-8 mm de largo; hipanto subcilíndrico-infundibuliforme, de 7-12 mm de largo x 22,5 $\mathrm{mm}$ de ancho en la parte media y hasta de $4 \mathrm{~mm}$ de ancho hacia el ápice, la base es redondeada, exteriormente el hipanto es hírtulo, más densamente hacia la base, con tricomas glandulares simples, capitados, rígidos y patentes o algo ascendentes, interiormente es glabro; sépalos triangulares a triangular-lanceolados, de 1,2-2 mm de largo x ca. $1 \mathrm{~mm}$ de ancho en la base, con indumento como el hipanto; pétalos ovados o anchamente elípticos, a veces obscura y angostamente rómbicos, con ápice agudo u obtuso, margen entero, de (5-)7-8 x (3-)4-5,5 $\mathrm{mm}$, amarillos a amarillo intenso o anaranjado, con 3-5 nervios más notables, pubescentes en la cara dorsal, con diminutos tricomas eglandulares ramificados, más profusamente hacia el ápice, en la cara ventral con abundantes tricomas glandulares moruliformes; estambres 3, 2 ditécicos y 1 monotécico; anteras dorsifijas; filamento muy breve, glabro; conectivo con tricomas glandulares ampuliformes en el ápice; tecas alantoides, de 4-4,5 mm de largo, rectas. Inflorescencia carpelada 1-flora, a veces coaxilar con la estaminada; pedicelo finamente estriado, ca. $3 \mathrm{~cm}$ de largo, alargándose hasta $9 \mathrm{~cm}$ en el fruto, esparcidamente hírtulo, con tricomas glandulares simples, capitados, patentes, más abundantes hacia el ápice; hipanto cilíndrico, de 9-13 x 4-6 mm, hírtulo en el exterior, glabro en el interior; sépalos lanceolados de 3,5-4 mm de largo, con indumento como el hipanto; corola similar a la de las flores estaminadas pero los pétalos mayores, de 7-20 x 5-11 mm; estaminodios 5, notables, ca. $2 \mathrm{~mm}$ de largo, subulados e incurvos, insertados cerca de la fauce del hipanto, a veces aproximados de a pares, resultando uno desapareado; ovario fusiforme o angostamente elipsoide, de 1,8-4 cm x 4-7 mm, base redondeada, ápice algo más angosto, glabro o glabrescente, superficie lisa y algo brillante, 3-placentífero; estilo columnar, glabro, ca. $1 \mathrm{~cm}$ de largo, con 3 ramas breves; estigmas 2-lobulados, lóbulos oblongoides de superficie papilosa. Fruto carnoso (en el herbario se torna duro, leñoso), indehiscente, oblongoide, de 3,5-7,2 x 0,7-1,3 cm, liso, enangostado hacia el ápice en un apiculo ca. $1 \mathrm{~cm}$ de largo. Semillas obovado-elipsoides, apenas comprimidas, de $5 \times 3 \mathrm{~mm}$ y ca. $2 \mathrm{~mm}$ de grosor, lisas, de color castaño-pajizo, con margen sagital apenas marcado, haciéndose más evidente hacia el extremo hilar. 


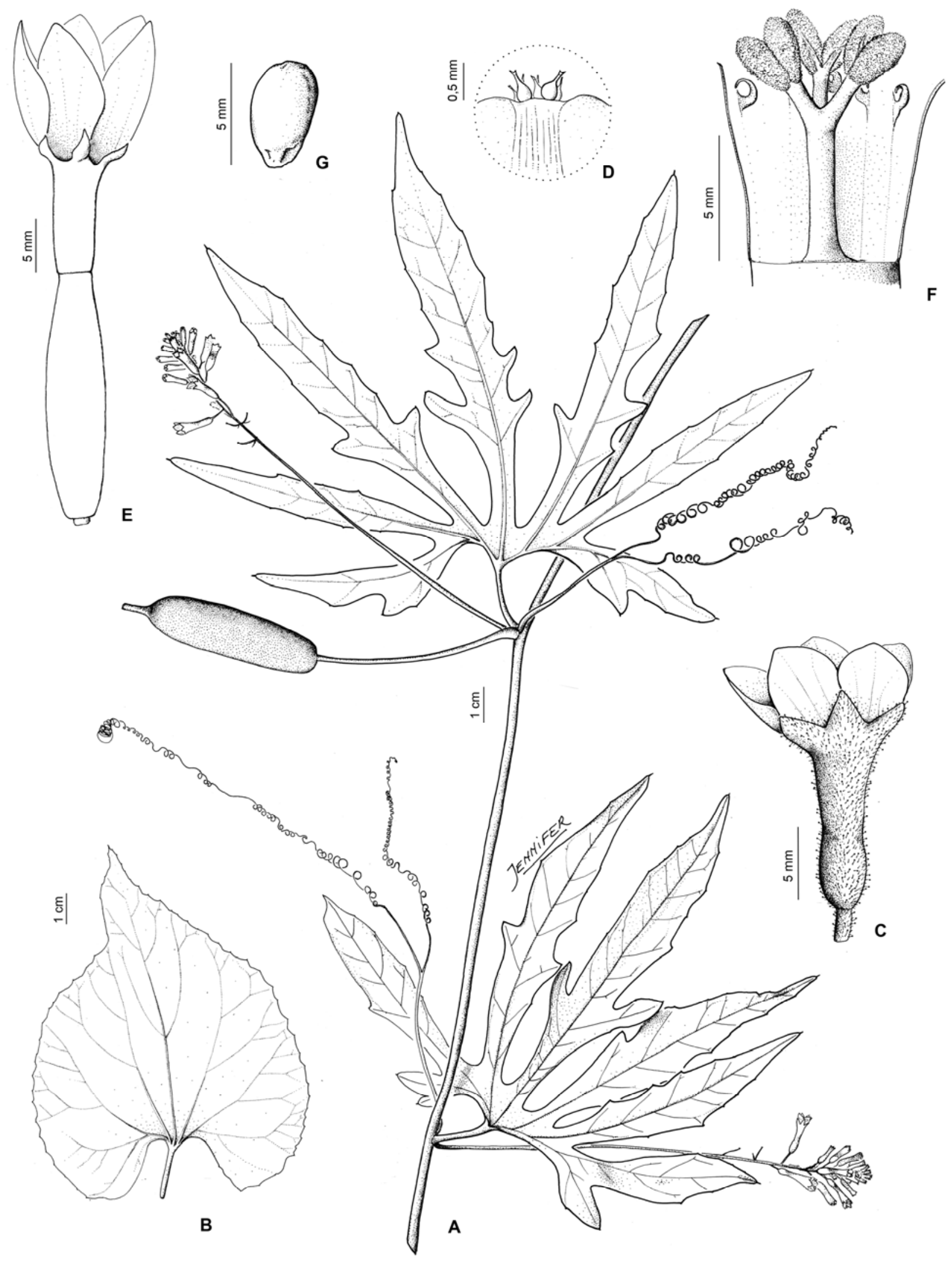

Figura 43. Apodanthera laciniosa. A. Tallo con hoja lobada característica, inflorescencias estaminadas y fruto. B. Hoja acorazonada. C. Flor estaminada, vista lateral. D. Tricomas glandulares ampuliformes del ápice del conectivo. E. Flor carpelada, vista lateral. F. Flor carpelada, corte longitudinal del hipanto y vista interna. G. Semilla. (Dibujo de Jennifer Castelo). A, C-F de Lima 367; B de Rambo 34924; G de Rambo 37163. 
Distribución geográfica y hábitat. Especie propia de la región Paranaense del sur de Brasil, entre los 900 y 1200 m s.m. y el extremo nordeste de la Argentina, en la provincia de Misiones (Figura 44), donde ha sido coleccionada sólo una vez en la zona de "campos" cerca de Santa Ana (ca. 150 m s.m.). Crece sobre árboles y arbustos en los bordes de selva.

Etimología. El epíteto específico laciniosa indica "con lacinias", aludiendo a las láminas, porfundamente 3-5(-9) lobadas (del latín "lacinia" = segmento, por lo general profundo, angosto y de ápice agudo).

Fenología. Florece y fructifica entre diciembre y febrero.

Observación 1. Esta especie se aparta de Apodanthera s. str. por presentar ovario fusiforme y lustroso, estaminodios notables, subulados y fuertemente incurvos, frutos oblongoides, apiculados y semillas apenas comprimidas, ligeramente marginadas. Adicionalmente, puede mencionarse que su distribución geográfica y hábitats son bien distintos a aquéllos de las especies de Apodanthera (A. laciniosa crece en zonas húmedas de la región Paranense mientras que Apodanthera s. str. lo hace en zonas áridas de los Andes). En la filogenia morfológica obtenida en esta tesis A. laciniosa se agrupa con el clado (Cucurbitella asperata + Apodanthera sección Cucurbitopsis); en la combinada, en cambio, queda sin resolución.

Observación 2. El holotipo en el herbario de Berlín (B) se ha destruido durante la Segunda Guerra Mundial. Por lo tanto, se ha elegido como lectotipo al espécimen Sello 4307 depositado en el Gray Herbarium (GH) de la Universidad de Harvard, al que se considera un duplicado (isotipo) del tipo (CINB, Arts. 9.9 y 9.10). La etiqueta de dicho espécimen indica "Ex-Herb. Reg. Berolinense, Brasilia. 4307, Sello legit". El mismo se ajusta perfectamente a la descripción original y está en perfecto estado de conservación.

Material adicional examinado. ARGENTINA. Misiones. Dpto. Candelaria: Santa Ana, 1887, G. Niederlein 1309 (BR). BRASIL. Paraná. Calmão, ad marginem silvae primaevae, 16 Mar 1910, P. Dusén 9326 (GH, NY). Mun. Clevelandia: Rincão Torcido, 15 Dic 1966, G. Hatschbach 15498 (K, UC). Mun. Inacio Martins: Goes Atigas, 9 Ene 1980, G. Hatschbach 42691 (CTES, K, NY). Mun. Palmas: Estrada Palmas-Ponte Serrada, 5 Dic 1971, G. Hatschbach et al. 28269 (K, UC). Rio Grande do Sul. Mun. Bom Jesus: Fazenda B. Velho, 3 Ene 1947, B. Rambo 34924 (MO, NY). Mun. Farroupilha: Farroupilha, 27 Ene 1949, B. Rambo 40202 (F, LIL). Mun. Jaquirana: Recosta, Mata do Gaspar, 900 m s.m., 27 Dic 2000, R. Wasum 849 (US). Estrada Cambará do Sul-Jaquirana, 28 54' 42.3”' S, 50 19' 25” W, 28 Dic 2006, L. F. Lima 367 (SI). Mun. Lagoa Vermelha: BR-285, km 61, 17 km E de Lagoa Vermelha, 23 Dic 1982, A. Krapovickas \& A. Schinini 38213 (CTES). Mun. Muitos Capoes: Esmeralda, E. E. Aracurí, 23 
Ene 1984, J. R. Stehmann 300 (F). Mun. São Francisco de Paula: Cambará, 3 Feb 1948, B. Rambo 37163 (SI). Vila Oliva, 13 Ene 1946, B. Rambo 31246 (LIL). Taimbé, 900 m s.m., 17 Ene 1963, A. Sehnem 8149 (F). Santa Catarina. "Serra Geral", Ene 1890, E. Ule 1472 (P). Mun. Agua Doce: Gallery forest, Campo das Palmas, $16 \mathrm{~km}$ northwest of Herciliópolis, ca. 2643'S 513'W, 1100-1200 m s.m., 5 Dic 1964, L. B. Smith \& R. Klein 13643 (F, NY, SI, US). Mun. Caçador: Pinheiral, $52 \mathrm{~km}$ west of Caçador near the eastern edge of the campos of Palmas, 1100-1200 m s.m., 23 Dic 1956, L. B. Smith \& R. Klein 9140 (NY). Pinheiral, 7 km north of Caçador, 950-1100 m s.m., 7 Feb 1957, L. B. Smith \& R. Klein 10981 (GH, US). Pinheiral, 8 km north of Caçador, 950-1100 m s.m., 21 Dic 1956, L. B. Smith \& R. Klein 8953 (UC, US). Mun. Pôrto União, 1100 m s.m., 7 Ene 1962, P. R. Reitz \& R. Klein 11711 (CTES). Mun. São Joaquim: Cambajuba, 1200 m s.m., 22-29 Ene 1950, P. R. Reitz 3273 (LIL). Invernadinha, perto da barra dos rios Rondinha e Portinho, 14 Ene 1966, J. Mattos 13087 (F). Ruderal, near Mantiqueira (27 km east of São Joaquim), 1100-1200 m s.m., 16 Ene 1957, L. B. Smith \& R. Klein 10224 (K, US). Mun. Urubici: 31 km de la SC 438, camino a Urubici (33 km S de Urubici), 26 Dic 1990, A. Krapovickas \& C. L. Cristóbal 43719 (CTES, K). São Paulo. Sin localidad consignada, 1833, C. Gaudichaud 980 (P).

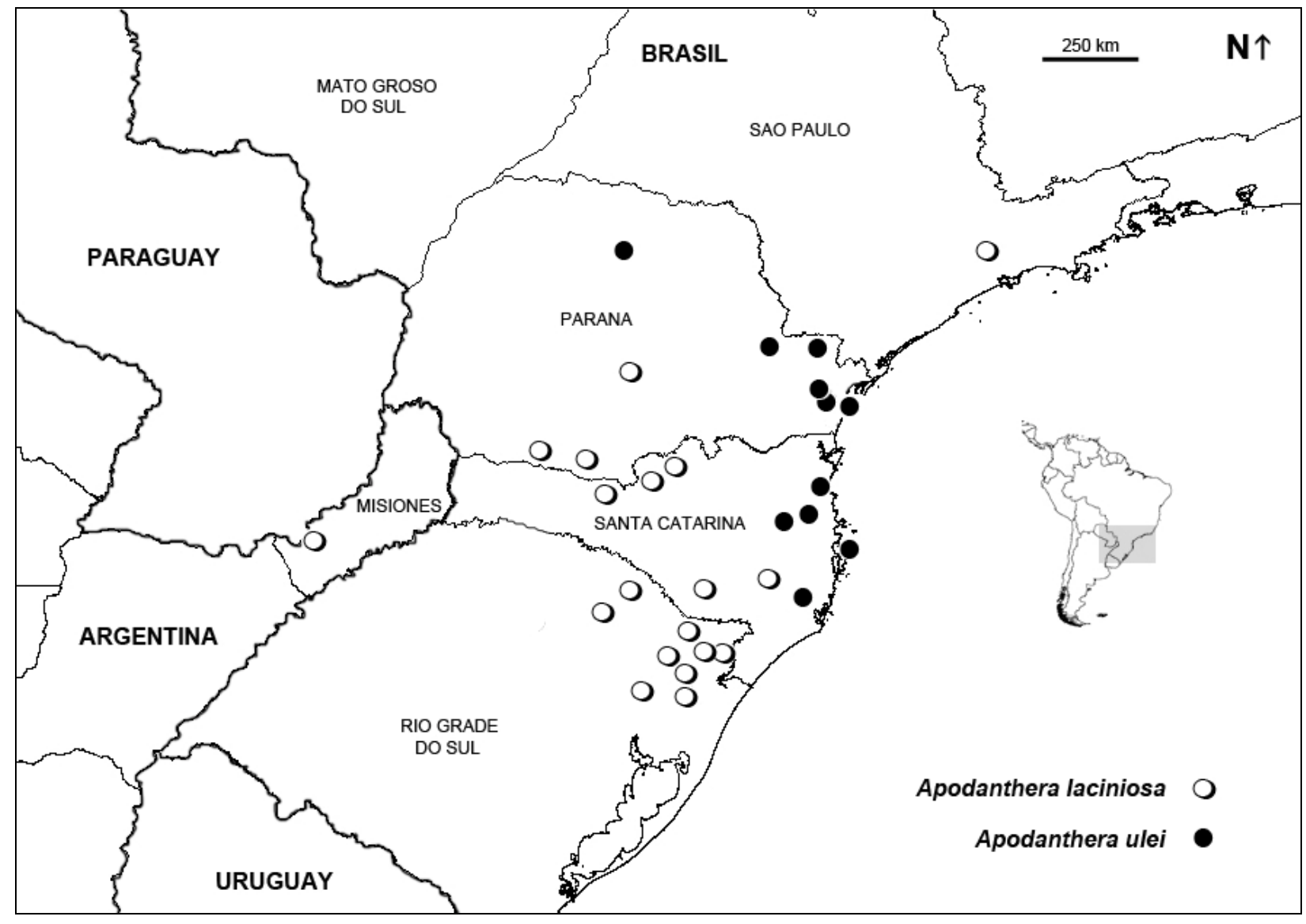

Figura 44. Distribución geográfica de Apodanthera laciniosa y A. ulei. 
5. Apodanthera ulei (Cogn.) Mart.Crov., Bol. Soc. Argent. Bot. 6: 97. 1956. Melothria ulei Cogn., Pflanzenr. 66 (IV. 275. I): 82. 1916. "Südbrasilinische Provinz: Staat. Santa Catarina, in einem Graben bei Tubarão (E. Ule n. 1141. - Blühend im Febr. 1889. - Herb. Berlin, Brüssel)". TIPO. Brasil. Santa Catarina. Tubarão, Feb 1889, E. Ule 1141 (lectotipo, BR-659 457!, designado por R. Martínez Crovetto, Bol. Soc. Argent. Bot. 6: 97. 1964; isolectotipos, BR-659 490!, HBG-506432!, P-751824!; foto serie Field Museum no 8985!). Figura 45.

Wilbrandia dusenii Harms, Repert. Spec. Nov. Regni Veg. 22: 343. 1926. "Brasilien: Paraná, Serra do Mar, Ypiranga, am Rande des Urwalds, 830 n ü. M. (P. Dusén no. 6531; VIII. 1908)". TIPO. Brasil. Paraná. Ypiranga: Serra do mar, ad marg. silvae prim., 29 Ago 1908, P. Dusén 6531 (lectotipo, NY-277918!, aquí desginado). Pro Syn., Paiva Lima (2010: 79). Apodanthera catharinensis Mart.Crov., Dusenia 4: 37. 1953. "Brasil; Santa Catharina, leg. de Stienstra, XII-1944 (SI, typus speciei); Isla del Francés, leg. B. de Stienstra n. ${ }^{0} 32.31-1-$ 1947 (SI)". TIPO. Brasil. Isla Santa Catharina, Dic 1944, B. de Stienstra s.n. (holotipo, SI25305!). Pro Syn., Paiva Lima (2010: 79).

Hierbas perennes, diclino-monoicas, zarcillosas; tallos anuales gráciles, hasta de 1,5 mm de diámetro, finamente estriados, glabrescentes, incluso en las partes jóvenes; entrenudos de 7,5$25 \mathrm{~cm}$ de largo. Pecíolos delgados, de 0,7-2,3 cm x 0,4-0,8(-1) mm, estriados, con tricomas eglandulares cónicos de base unicelular, blanquecinos, adpreso-ascendentes; láminas de contorno anchamente ovado o subpentagonal, simples y 3-5-lobadas o compuestas y 3folioladas (con los lóbulos laterales irregularmente 2-lobulados), de 9-19 x 10-17,5 cm, base profundamente cordada, tenuemente membranáceas, de color verde claro, algo más pálildo en la cara abaxial, pilosas, esparcidamente en la cara adaxial, más densamente en la abaxial, principalmente sobre los nervios, con tricomas eglandulares cónicos, de base unicelular, blanquecinos, algo adpresos, de célula apical aguda y primera célula del pedículo ensanchada, junto con otros tricomas cónicos de base multicelular, pequeños; lóbulos o folíolos de contorno linear-oblongo, lanceolado o elíptico, de ápice poco a largamente acuminado, margen subentero o corta e irregularmente dentado, remotamente dentículado, con hidátodos subtriangulares, ca. $0,5 \mathrm{~mm}$ de largo (el del lóbulo o folíolo apical hasta de $2 \mathrm{~mm}$ ), senos angostos a notablemente amplios. Zarcillos compuestos, 2-fidos, rectos en la yema, finamente estriados, glabrescentes, portazarcillos más o menos rectos, hasta de $4 \mathrm{~cm}$ de largo, una de las ramas es notablemente más delgada que la otra. Inflorescencia estaminada racemiforme, pedunculada, 7-20-flora; pedúnculo ascendente, hasta de $10 \mathrm{~cm}$ de largo, glabrescente o esparcidamente hispídulo, con tricomas eglandulares cónicos de base unicelular, algo incurvos, más abundantes hacia el ápice; pedicelos breves, de 1-3,5(-4,5) $\mathrm{mm}$ de largo en las flores abiertas, persistentes, usualmente recurvados, luego de la absición de la flor queda una cicatriz 
blanquecina, algo ensanchada, en el ápice del pedicelo, poco a profusamente hispídulos, con tricomas eglandulares cónicos de base unicelular, cortos incurvos. Flores estaminadas ebracteadas; hipanto acampanado, de 3-5 mm de largo x 3-4 mm de ancho en el ápice, la base del hipanto es más o menos redondeada, glabrescente a pilhírtulo, con tricomas cortos, glandulares, capitados, simples, patentes, interiormente el hipanto es villoso cerca de la fauce, en la zona en que se insertan los filamentos estaminales, estos tricomas son muy delgados y largos (con más de 20 células, irregularmente cilíndricas, con aspecto de falange) y en el pimpollo están dispuestos en sentido longitudinal al tubo; sépalos de contorno triangular, de 0,8-1,4 mm de largo x 0,8-1 mm de ancho en la base, esparcidamente pilosos a glabrescentes exteriormente, glabros interiormente; corola de prefloración imbricada y pétalos de vernación ligeramente involuta, libres hasta la base, de 1,8-3,5 x 1,5-2,4 mm, de contorno ovado a elíptico, ápice agudo a obtuso, algo redondeado, margen entero, de color amarillo pálido, con 5-nervios más o menos paralelos, poco evidentes, interiormente glabrescentes, exteriormente con una pubescencia afelpada de tricomas brevísimos, muy abundantes; estambres 3, 2 ditécicos y 1 monotécico, usualmente coherentes; anteras dorsifijas, insertadas en la fauce del hipanto, resultando exerta su mitad superior; filamento breve, glabro; conectivo angosto, glabro o veces con algunos tricomas glandulares ampuliformes, poco conspicuos, en el ápice; tecas alantoideas o botuliformes, de 1,6-2 $\mathrm{mm}$ de largo, rectas o apenas arqueadas, a veces asimétricas, dehiscencia longitudinal; pistilodio ausente; nectario mesenquemático ausente. Inflorescencia carpelada 1(-2)-flora; pedicelo ascendente, hasta de $6 \mathrm{~cm}$ de largo, piloso, con tricomas patentes; flor carpelada ebracteada; hipanto acampanado, de 3-4 mm de largo x 2,5-3 $\mathrm{mm}$ de ancho en el ápice, esparcida y cortamente piloso exteriormente, interiormente villoso en la fauce; sépalos angostamente triangulares, de 1-1,5 mm de largo x ca. $1 \mathrm{~mm}$ de ancho en la base, con indumento como el hipanto; pétalos lanceolados o cortamente ensiformes, de 3,5-4 x 1,7-2,5 mm, obscuramente 3-5-nervios, puberulentos en ambas caras; estaminodios 3, subtriangulares o setiformes, ca. 0,5 mm de largo, insertados cerca de la fauce del hipanto, en la base de los pétalos, opuestos o alternos a éstos; ovario ovoide o angostamente elipsoide, redondeado en la base, de $6 \times 2,5 \mathrm{~mm}$, glabrescente, algo brillante, 2-placentífero; estilo columnar, glabro, hasta de 4,5 mm de largo, con 2 ramas; estigmas obscuramente 2-lobulados, de superficie papilosa; óvulos horizontales. Fruto carnoso indehiscente, anchamente elipsoide o subgloboso, ca. $2 \times 1,5 \mathrm{~cm}$, apenas rostrado, superficie lisa, glabra, de color rojo oscuro cuando maduro. Semillas maduras 4-8 por fruto, ovado-elipsoides, de 9 x 5,5 mm y ca. 4,5 mm de grosor, superficie lisa, de color castaño, emarginadas, sólo la porción hilar algo comprimida.

Distribución geográfica y hábitat. Especie propia de los estados de Paraná y Santa Catarina, en la región sudeste de Brasil (Figura 44), también ha sido citada para Rio de Janeiro (Paiva Lima, 2010). Habita en bordes y claros de selvas, tanto de ambientes cercanos al océano como en laderas húmedas de sierras continentales, hasta los 900 m s.m. 


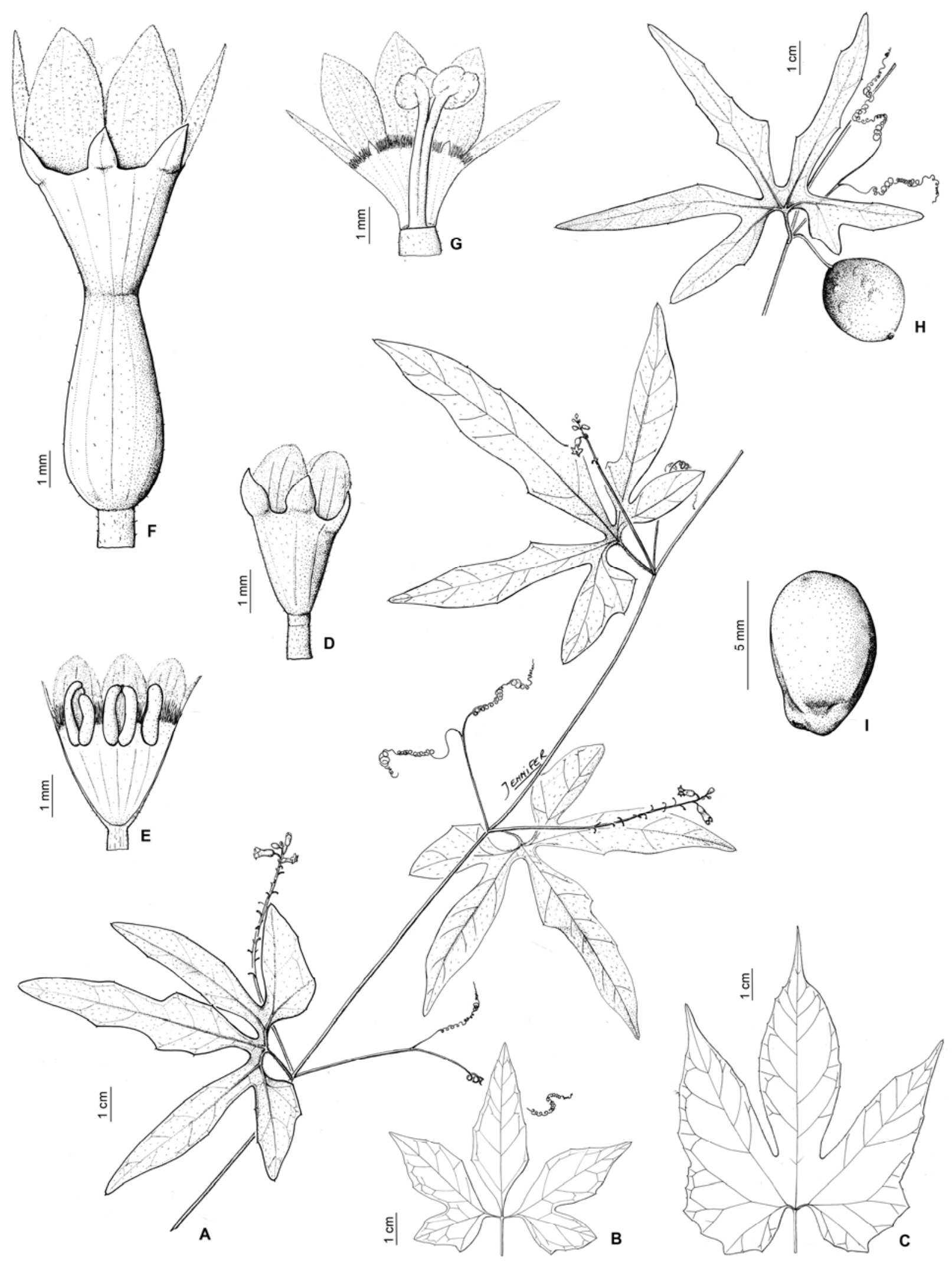

Figura 45. Apodanthera ulei. A. Tallo con inflorescencias estaminadas. B. Hoja foliolada. C. Hoja lobada. D. Flor estaminada, vista lateral. E. Flor estaminada, corte longitudinal. F. Flor carpelada, vista lateral. G. Flor carpelada, corte longitudinal del hipanto, vista interna. H. Nudo con fruto. I. Semilla. (Dibujo de Jennifer Castelo). A, D-E de Reitz 8606; B de Stienstra s.n; F-G de K de Koczicki 230. 


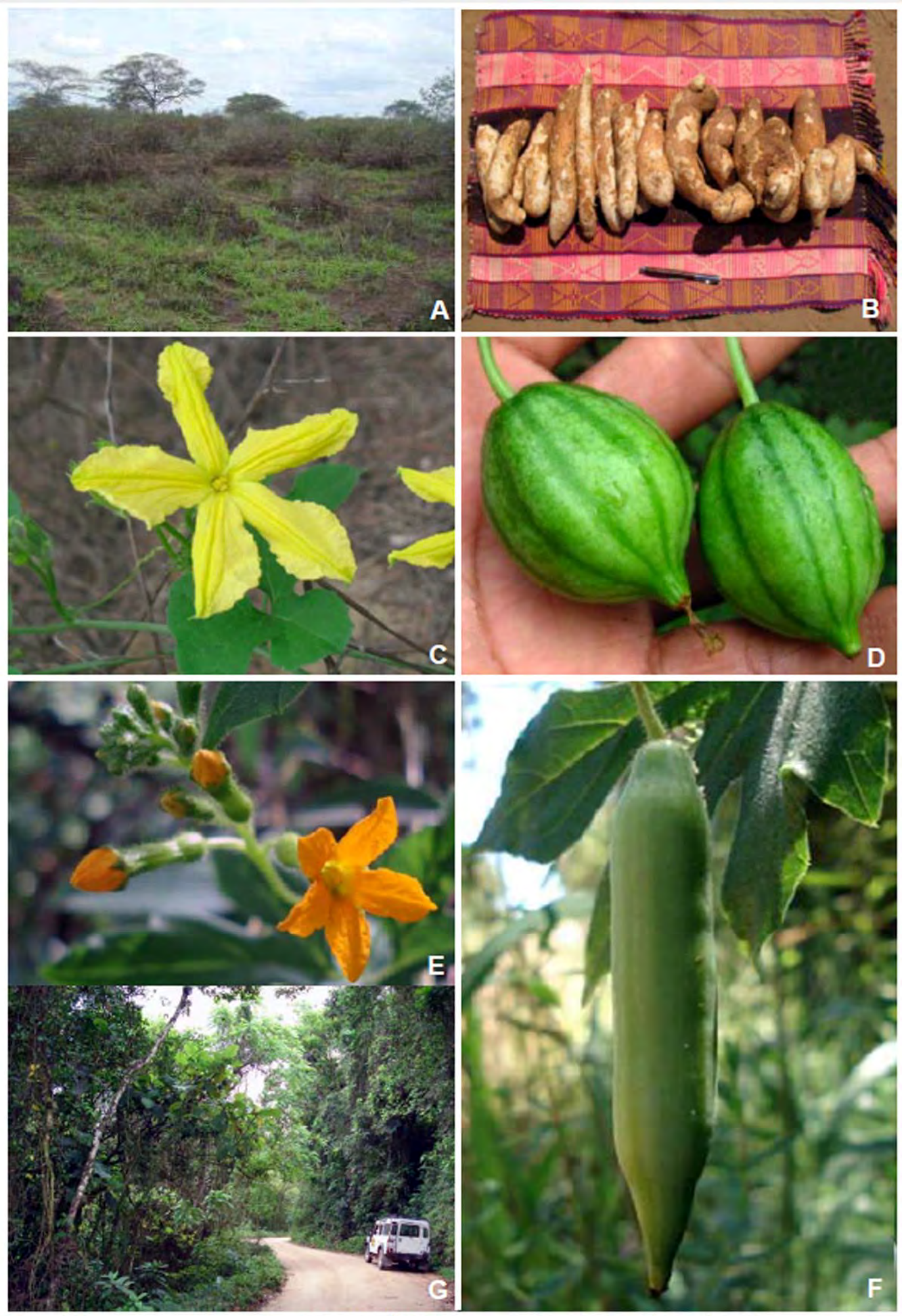

Figura 46. Incerta saedis. Apodanthera bifiora. A. Hábitat: bosque seco del norte de Perú. B. Raices tuberosas empleadas como alimento. C. Flor estaminada. D. Frutos. (Tomadas de W. González, Universidad Peruana Cayetano Heredia). Apodanthera laciniosa. E. Inflorescencia estaminada. F. Fruto. G. Hábitat: selvas montanas del sudeste de Brasil (Tomadas de Paiva Lima 2010). 
Etimología. La especie fue nombrada en honor de Ernts H. G. Ule (1854-1915), botánico, médico y explorador alemán que realizó importantes colecciones botánicas en Brasil durante el siglo XIX, coleccionista del ejemplar tipo de la especie.

Fenología. Se han estudiado especímenes floridos tanto en los meses de verano como en los de invierno y primavera; no se observa estacionalidad.

Observación 1. Esta especie se aparta de Apodanthera s. str. por el hipanto de las flores estaminadas campanulado, con pubescencia profusa en la garganta y frutos pauciseminados, entre los caracteres más destacados. La filogenias morfológica y combinada la agrupan con Apodanthera anatuyana (véase comentario bajo esta especie).

Observación 2. En la descripción original de Apodanthera catharinensis, Martínez Crovetto indica que el receptáculo másculino posee una dilatación membranosa pequeña en cada una de sus 5 nervaduras principales, a la altura del tercio superior, característica que no ha podido observarse trás estudiar el material tipo. Asímismo, indica que el ovario es 3-placentífero; sin embargo, la única flor carpelada que se cuenta entre el material original está muy modificada hacia el fruto, carece de estigma y en corte transversal presenta dos placentas. Luego de estas aclaraciones y de estudiar el material tipo de $A$. catharinensis y $A$. ulei se ha constatado que pertenecen a la misma entidad.

Observación 3. En el herbario de Bruselas (BR) hay dos hojas de Ule 1141; sin embargo, sólo la que lleva el número BR-659 457 lleva identificación de Martínez Crovetto y está marcada como "lectotypus!", considerándosela como el lectotipo designado por este botánico.

Observación 4. Si bien en el protólogo de Wilbrandia dusenii no se especifica el herbario de depósito del ejemplar tipo, se supone que el mismo es el herbario de Berlín (B), por cuanto allí trabajaba Harms y además, porque existe una fotografía del mismo en la serie Field (no. 8964). Sin embargo, el mencionado ejemplar se ha destruido durante la Segunda Guerra Mundial; por este motivo se ha procedido a designar un lectotipo, según lo estipula el CINB (Art. 9.9, 9.10), para ello se ha seleccionado un isotipo depositado en NY, que se ajusta perfectamente al protólogo. Paiva Lima (2010) fue primero en establecer esta sinonimia, sin embargo, no designó lectotipo en esa oportunidad.

Materila adicional examinado. BRASIL. Paraná. Mun. Adrianópolis: Paranaí, 26 Feb 1962, G. Hatschbach 9289 (K). Mun. Campina Grande do Sul: Serra Capivari Grande, 900 m s.m., 12 Ago 1969, C. Koczicki 230 (K). Mun. Cerro Azul: Barra do Lagedo Grande, 31 Ago 1978, G. Hatshcbach 41562 (CTES, NY). Mun. Guaratuba: Rio Itararé, 13 Oct 1957, G. Hatschbach 
4273 (CTES). Mun. Morretes: Véu de Noiva, 4 Dic 1986, J. M. Silva \& J. Cordeiro 256 (US). Estación Marumbi, Rio Taquaral, 18 Ago 1946, G. Hatschbach 344 (LIL, US). Rio Taquaral, 6 Jul 1982, G. Hatschbach 44978 (MO, UC, US). Santa Catarina. Mun. Brusque: Limoeiro, $30 \mathrm{~m}$ s.m., 18 Sep 1952, P. R. Reitz 5859 (CTES). Mun. Florianópolis: Isla do Francés, 31 Ene 1947, B. de Stienstra 32 (SI). Mun. Joinville: estrada Dona Francisca, 500 m s.m., 4 Oct 1957, P. R. Reitz \& R. M. Klein 5019 (CTES). Mun. Rio do Sul: Rio do Sul, 400 m s.m., 14 Mar 1959, P. R. Reitz \& R. M. Klein 8606 (CTES, US). Rio do Sul, 400 m s.m., 27 Ene 1958, P. R. Reitz \& R. M. Klein 8385 (CTES).

\section{Taxón dudoso}

Apodanthera Iongipedicellata (Cogn.) H.Schaef. \& S.S.Renner, Taxon 60(1): 133. 2011. Basónimo: Guraniopsis longipedicellata Cogn., Bot. Jahrb. Syst. 42: 173. 1908. "Peru: Dep. Junin, in provincia Tarma, supra Huacapistana prope viam ad Palca, ad marginem fruticetroum ad rupes humidas, 1700-1900 m s. m. (Weberbauer n. 1969 - florens mense Januario 1903)". TIPO. Perú. Dpto. Junín. Prov. Tarma. Huacapistana, 1700-1900 m s.m., 6 Ene 1903, A. Weberbauer 1969 (lectotipo, BR-530 373!, aquí designado). Figura 47.

El único material original que ha podido localizarse es un fragmento depositado en el herbario del Jardín Botánico de Bruselas (BR), al que sólo se ha tenido acceso a través de una imagen digital, y que consta únicamente de una hoja y 2 flores estaminadas separadas (Figura 47A). Seguramente, los fragmentos de este espécimen provengan del tipo depositado en $B$, donde $A$. Weberbauer depositaba sus originales y destruido durante la Segunda Guerra Mundial, del cual se conserva una fotografía de la Serie Field Museum No 8973 (Figura 47C). El isotipo de BR es designado aquí como lectotipo, según lo indica el CINB (Art. 9.9, 9.10).

Cogniaux (1908) indicó, entre otras características, que el nuevo género Guraniopsis se caracteriza por poseer dos anteras ditécicas insertadas a media altura del hipanto, como ocurre en el género Gurania (de allí el origen etimológico del nombre del primero). Sin embargo, tanto en la imagen del lectotipo en BR como en una ilustración publicada posteriormente por el autor de la especie (Cogniaux 1916: 193) (Figura 47B) puede constatarse que las anteras están insertadas en el tercio superior del hipanto, como ocurre en las especies de Apodanthera. A partir de la imagen digital del lectotipo no es posible constatar que sólo posea 2 anteras, en lugar de 3, como ocurre usualmente en Apodanthera. Adicionalmente, la ilustración antes mencionada se contradice con la descripción original en otros caracteres: para las flores estaminadas, la descripción original indica que el conectivo es "non producto", cuando en la ilustración se observa un apéndice apical; para las flores carpeladas, la descripción original indica "Staminodia nula (...) stigmatibus 2, brevibus, crassis, bifidis", cuando en la ilustración, 
claramente se observan al menos 3 estaminodios setiformes en el interior del hipanto y 5 estigmas 2-lobulados en forma de "U", como ocurre en las especies de Apodanthera.

Schaefer \& Renner (2011a) basaron su estudio molecular, y la posterior transferencia de este taxon a Apodanthera, en el ejemplar Hutchinson 1152 (F) (Figura 47D), estudiado para esta tesis y que pertenece a Apodanthera mathewsii. De todos modos, es muy probable que esta transferencia sea correcta y, posiblemente, Apodanthera longipedicellata sea un sinónimo de $A$. mathewsii, fundado sobre la base de un espécimen con pedicelos y sépalos más largos que lo usual (pedicelos hasta de $8 \mathrm{~cm}$ de largo en A. longipedicellata vs. $4 \mathrm{~cm}$ en $A$. mathewsii; y sépalos ca. $10 \mathrm{~mm}$ de largo en $A$. longipedicellata vs. 4-5 mm en $A$. mathewsii).

Por los motivos antes enunciados este taxón se considera dudoso y, por tanto, no ha sido considerado en el estudio filogenético (Capítulo 3).

\section{Taxones previamente excluidos de Apodanthera}

1. Apodanthera gracilis Benth., Voy. Bot. Sulphur: 99. 1845. "Isle of Taboga, Salango". SINTIPOS no localizados = Melothria pendula L., Sp. PI. 1 : 35. 1753.

Las colecciones originales sobre las cuales Bentham basó sus descripciones fueron realizadas por George W. Barclay, jardinero y coleccionista de Kew Gardens, durante su viaje de circunvalación a bordo del H.M.S. Sulphur entre 1836 y 1841. En el herbario del British Museum (BM), donde Barclay depositó los originales, no se ha localizado ningún material original de $A$. gracilis, tampoco en $\mathrm{K}$ (duplicados), por lo cual no se ha podido caracterizar adecuadamente a esta especie. En la descripción original, Bentham indica que $A$. gracilis se asemeja a Melothria fluminensis Gardner; Cogniaux (1881) las consideró conespecíficas; actualmente ambos nombres son considerados sinónimos de $M$. pendula L. Adicionalmente, las localidades de colección de los dos sintipos de A. gracilis, en las islas de Taboga (Panamá) y Salango (Ecuador), en el Océano Pacífico, están dentro del rango distribucional de M. pendula, no así del de Apodanthera, cuyas especies crecen en ambientes semiáridos y montañosos de los Andes sudamericanos.

2. Apodanthera pringlei S. Watson, Proc. Amer. Acad. Arts. 25: 149. $1890=$ Melothria pringlei

(S. Watson) Mart.Crov., Notul. Syst. (Paris) 15: 46. 1954. "Under ledges near Guadalajara; Novermber, 1888 (n. 2140)". TIPO, no localizado.

No ha podido localizarse el ejemplar tipo ni ningún otro material original de esta especie; tampoco R. Martínez Crovetto, el botánico que realizó la transferencia a Melothria. Cogniaux (1916) citó dos especímenes para esta especie: Pringle 2140, el ejemplar tipo, que no ha sido localizado, y Pringle 4523 de la misma procedencia pero que fue coleccionado en 1893 y por lo 


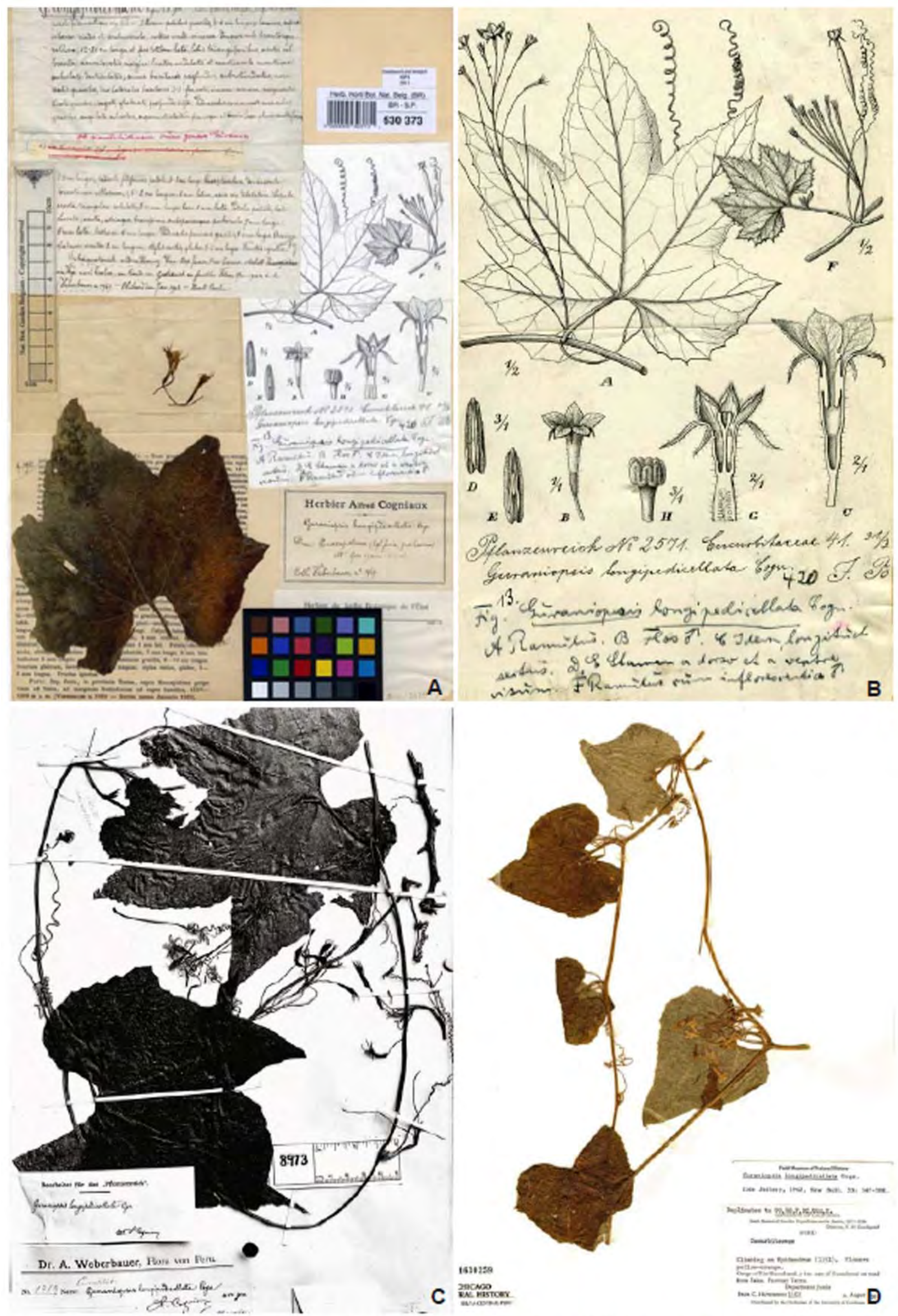

Figura 47. Apodanthera longipedicellata. A. Weberbauer 1969 (lectotipo, BR). B. llustración sobre el lectotipo con anotaciones origianles, publicada en Pflanzenreich 66 (IV. 275. I): 193. C. Fotografia de la serie Field Museum $\mathrm{N}^{\circ}$ 8973. D. Especimen Hutchinson 1152 (F) sobre el cual Schaefer \& Renner basaron su filogenia molecular. 
tanto no puede ser considerado material original. De este último ejemplar se han encontrado duplicados en los herbarios BR (649198!) y MO (38912!) y han sido colocados bajo Melothria. Adicionalmente, la descripción original de A. pringlei también se corresponde con Melothria.

3. Apodanthera scaberrima Brandegee, Univ. Calif. Publ. Bot. 10(2): 188. 1922. "Barranca de Panoaya, Vera Cruz. No. 8685. Type Herb. Univ. Calif. No. 208381". TIPO. México. Veracruz. Barranca de Panoaya, Nov 1921, C. A. Purpus 8635 (holotipo, UC-298381!; isotipo, NY 172324!) = Cucumis anguria L., Sp. PI. 2: 1011. 1753. Pro syn., Martínez Crovetto (1956: 97).

Luego del estudio del tipo de A. scaberrima pudo corroborarse la sinonimia propuesta por R. Martínez Crovetto. Cucumis anguria es una especie muy conocida y de amplia distribución en América y África, el tipo de A. scaberrima coincide en todos sus atributos con $C$. anguria, incluso el característico conectivo, notablemente producido en el ápice, a modo de cresta bífida. Cabe mencionar que en el protólogo se indicó erróneamente el número de colección del tipo como "8685".

4. Apodanthera scabra Cogn., Bull. Acad. Roy. Belgique, sér. 2 49: 192. 1880. "Ec.: ad San Florencio, in decliv. occid. mont. Corazon, altit. 1500 metr. prope Canchacoto, altit. 2000 metr. (n. 3673)" = Melothria longituba C. Jeffrey, Kew Bull. 33: 349. 1978, nom. nov., non Melotrhia scabra Naudin, 1867. TIPO. Ecuador, prope Canchacoto, in decliv, occid. Mount. Corazon, 2000 m s.m., 21 Jun 1846, E. André 3673 (lectotipo, K 430942!, aquí designado; isolectotipo, NY 172326!).

El estudio de dos duplicados del tipo (en $\mathrm{K}$ y NY) de $A$. scabra permitió corroborar que pertenecen a Melothria, como lo propuso C. Jeffrey, en éstos las anteras tienen tricomas pestañosos, característicos de muchas especies de Melothria. El ejemplar en $\mathrm{K}$ es designado aquí como lectotipo de la especie; al hacer la transferencia, Jeffrey (1978) lo indicó como "syntype", sin designar lectotipo.

5. Apodanthera smilacifolia Cogn., Mém. Couronnes Autres Mém. Acad. Roy. Sci. Belgique 27: 42. 1877. "In Brasilia: in fruticetis humidiusculis prope Mand et Serra late (Riedel, in herb. Acad. Petrop.); in prov. Minas Geraes (A. de Saint-Hilaire, $B^{1}$, n. 736, in hb. Mus. Paris); in eadem prov. In locis umbrosis, secus rivos ad Ponte-Alta (A. de Saint-Hilaire, $B^{1}, n$. 851, in hb. Mus. Paris)" = Melothrianthus smilacifolius (Cogn.) Mart.Crov., Notul. Syst. 15: 60. 1954. TIPO. Brasil. Minas Gerais, 1816-1821, A. de Saint-Hilaire $B^{1} 851$ (lectotipo, P-257363!, designado por R. Martínez Crovetto, Notul. Syst. 15: 60. 1954). 
Martínez Crovetto (1954c) escindió a Apodanthera smilacifolia y fundó el género Melothrianthus con la única especie M. smilacifolius (véase Capítulo 1, Relaciones intergenéricas).

5a. Apodanthera smilacifolia Cogn. var. angustifolia Cogn., Pflanzenr. 66(IV. 275. I): 60. 1916. "Prov. Minas Gerais, bei Ouro Preto (Schwacke n. 9387); Prov. Rio de Janeiro, Petropolis (Glaziou n. 17009)". TIPO. Brasil. Rio de Janeiro. Nova Friburgo, 30 Jul 1887, A. Glaziou 17009 (lectotipo, P-257357!, designado por R. Martínez Crovetto, Notul. Syst. 15: 60. 1954; isolectotipo, K-435977!). = Melothrianthus smilacifolius (Cogn.) Mart.Crov. Pro syn., Martínez Crovetto (1954c: 60).

El estudio de los tipos de la variedades smilacifolia y angustifolia, conjuntamente con otro material de herbario perteneciente a esta especie, permitió comprobar la gran variación en el ancho de la lámina foliar, de modo que no se justifica mantener a las dos variedades por separado.

\section{Taxones excluidos de Apodanthera en esta tesis}

Apodanthera Arn. sect. Cucurbitopsis Cogn. = Cucurbitopsis (Cogn.) Mart.Crov. ex Belgrano Apodanthera Arn. sect. Pseudoapodanthera Cogn. = Pseudoapodanthera (Cogn.) Belgrano Apodanthera argentea Cogn. = Melothrianthus argenteus (Cogn.) Belgrano Apodanthera argentea Cogn. var. angustifolia Cogn. = Melothrianthus argenteus (Cogn.)

Belgrano. Pro syn., Gomes Klein (1996: 103)

Apodanthera argentea Cogn. var. latifolia Cogn. = Melothrianthus argenteus (Cogn.)

Belgrano. Pro syn., Gomes Klein (1996: 103)

Apodanthera aspera Cogn. = Cucurbitopsis aspera (Cogn.) Mart.Crov. ex Belgrano

Apodanthera bradei Mart. Crov. = Pseudoapodanthera pedisecta (Cogn.) Belgrano. Pro syn.,

Paiva Lima (2010: 75)

Apodanthera buraeavi Cogn. = Cucurbitopsis aspera (Cogn.) Mart.Crov. ex Belgrano. Pro syn., Lira \& Rodríguez Arévalo (1999: 8)

Apodanthera congestiflora Cogn. $=$ Doyerea trifoliata (Cogn.) Belgrano. Syn. nov.

Apodanthera crispa Cogn. = Cucurbitopsis aspera (Cogn.) Mart.Crov. ex Belgrano. Syn. nov. Apodanthera cucurbitoides Lundell = Cucurbitopsis aspera (Cogn.) Mart.Crov. ex Belgrano.

Syn. nov.

Apodanthera fasciculata Cogn. $=$ Pseudoapodanthera fasciculata (Cogn.) Belgrano Apodanthera galeottii Cogn. = Cucurbitopsis aspera (A. Gray) Belgrano. Pro syn., Lira \& Rodríguez Arévalo (1999: 8)

Apodanthera glaziovii Cogn. = Melothrianthus glaziovii (Cogn.) Belgrano 
Apodanthera hatschbachii C. Jeffrey = Pseudoapodanthera pedisecta (Cogn.) Belgrano. Pro syn., Paiva Lima (2010 : 75).

Apodanthera hindii C. Jeffrey = Pseudoapodanthera hindii (J. Jeffrey) Belgrano

Apodanthera lasiocalyx Cogn. = Melothrianthus glaziovii (Cogn.) Belgrano. Pro syn., Jeffrey (1992 : 518), por error como A. eriocalyx Cogn.

Apodanthera linearis (Cogn.) Mart.Crov. = Melothrianthus sagittifolius (Griseb.) Belgrano.

Syn nov.

Apodanthera palmeri S.Watson = Cucurbitopsis palmeri (S. Watson) Mart.Crov. ex Belgrano Apodanthera pedisecta Cogn. = Pseudoapodanthera pedisecta (Cogn.) Belgrano

Apodanthera roseana Cogn. = Cucurbitopsis palmeri (S. Watson) Mart.Crov. ex Belgrano.

Syn. nov.

Apodanthera sagittifolia (Griseb.) Mart.Crov. = Melothrianthus sagittifolius (Griseb.) Belgrano Apodanthera sagittifolia (Cogn.) Mart.Crov. var. dissecta (Cogn.) Mart.Crov. = Wilbrandia villosa

Cogn. var. dissecta Cogn. $=$ Melothrianthus sagittifolius (Cogn.) Belgrano. Syn. nov. Apodanthera sagittifolia (Griseb.) Mart.Crov. var. villosa (Cogn.) Mart.Crov. $=$ Willbrandia villosa Cogn. $=$ Melothrianthus sagittifolius (Griseb.) Belgrano. Syn nov.

Apodanthera succulenta C. Jeffrey = Pseudoapodanthera villosa (C. Jeffrey) Belgrano. Syn. nov.

Apodanthera trifoliata Cogn. $=$ Doyerea trifoliata (Cogn.) Belgrano

Apodanthera undulata A. Gray = Cucurbitopsis undulata (A. Gray) Mart.Crov. ex Belgrano Apodanthera undulata A. Gray var. australis McVaugh = Cucurbitopsis aspera (Cogn.) Mart.Crov. ex Belgrano. Syn. nov.

Apodanthera villosa C. Jeffrey = Pseudoapodanthera villosa (C. Jeffrey) Belgrano 
Cucurbitopsis (Cogn.) Mart.Crov. ex Belgrano, comb. et stat. nov. Basónimo: Apodanthera Arn. sect. Cucurbitopsis Cogn., Mem. Couronnes Autres Mem. Acad. Roy. Sci. Belgique 27: 40. 1877. ESPECIE TIPO. Cucurbitopsis undulata (A. Gray) Mart.-Crov. ex Belgrano (= Apodanthera undulata A. Gray), lectotipo aquí designado.

Hierbas perennes, diclino-monoicas, zarcillosas; raíz tuberosa, muy engrosada, que penetra en el suelo a escasa profundidad y se bifurca en forma opuesta y sucesivamente, de modo que todo el sistema ocupa una amplia superficie relativamente cerca de la superficie; tallos perennes numerosos, leñosos, verticales, cortos y principalmente subterráneos, de los que emergen numerosos tallos anuales zarcillosos, rastreros por falta de soporte circundante, hasta de varios metros de longitud, que se extienden sobre el suelo en forma radiada, estriados o ligeramente costados longitudinalmente, glabrescentes a hirsutos (más profusamente en las partes jóvenes); los tallos anuales están cubiertos de tricomas eglandulares blanquecinos, uniseriados, filiformes o cónicos de base unicelular, agudos, entremezclados con otros tricomas más robustos y cortos, con corona de células accesorias, primera célula del pedículo engrosada y célula apical aguda, algo geniculada (la porción apical de estos tricomas gruesos es caediza mientras que las células accesorias y basales son persistentes semejando, en ocasiones, diminutos dentículos blanquecinos y confiriendo aspereza a la superficie). Hojas larga o cortamente pecioladas, usualmente ascendentes o erectas desde los tallos rastreros; pecíolos usualmente robustos, algo aplanados, estriados longitudinalmente, usualmente escabrosos o hirsutos como los tallos; láminas suborbicular-reniformes, subenteras a 3-5lobadas (poco a profundamente), de base cordada, margen ondulado, a veces crispado o dentado, remotamente denticulados, con hidátodos triangulares, blanquecinos, consistencia subcrasa, en ambas caras el indumento es smiliar al de los tallos pero mucho más denso y los tricomas cónicos de base unicelular y los de base multicelular se disponen en distintas proporciones relativas confiriendo a la superficie mayor o menor aspereza; láminas discolores, la cara adaxial es de color verde, es usualmente escabrósula, con tricomas esparcidos, la cara abaxial es áspera o estrigosa o densamente cano-tomentosa, con tricomas blanquecinos, adpresos, más profusamente sobre los nervios; lóbulos, cuando presentes, anchamente elípticos, ovados u oblongo-lanceolados, de ápice redondeado o triangularmente obtuso. Zarcillos compuestos, 2-fidos, menos frecuentemente 3-fidos (una de las ramas se divide en otras 2), rectos en la yema, estriados, ralamente pilosos o hírtulos; el portazarcillos es muy

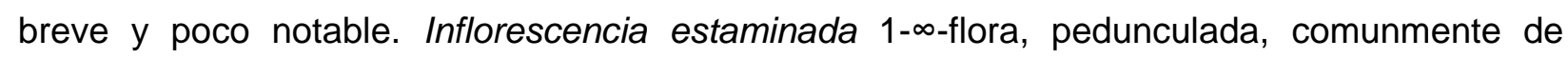
aspecto fasciculiforme o más raramente racemiforme, pedunculada, 1 por nudo (excepcionalmente 2), rara vez con 1 ó más flores no desarrolladas cerca de la base; pedúnculo erecto o ascendente, estriado longitudinalmente, hírtulo, tornándose glabrescente; pedicelos persistentes, hirsutos. Flores estaminadas bracteadas; bráctea presente hacia la base del pedicelo, caduca, hírtula a hirsuta, la mayoría de las veces es linear o lanceolada, con 
margen entero o apenas denticulado; hipanto subcilíndrico-infundibuliforme, más raramente subcampanulado, ensanchado gradualmente hacia el ápice, la base puede estar atenuada hacia el pecíolo o ser redondeada y más ancha que la porción media, con un nectario mesenquimático craso y disciforme, exteriormente el hipanto es glabrescente a hirsuto (a veces lanoso en los pimpollos), con tricomas eglandulares filiformes y cónicos ascendentes, interiormente es villoso en su mitad superior, cerca de la garganta, en la zona de inserción de los filamentos estaminales, o por debajo de las anteras, con tricomas filiformes; sépalos lineares a subulados, pubescentes a hirsutos, a veces algo recurvos; corola de prefloración imbricada y pétalos de vernación involuta, libres hasta la base, oblongo-obovados o angosta a anchamente elípticos o lanceolados, de ápice agudo a obtuso, redondeado o emarginado, usualmente apiculado, de color amarillo o amarillo-anaranjado, con 3-5 nervios principales, cortamente pilosos en la cara dorsal, principalmente sobre los nervios y el margen (densamente pubescentes en los pimpollos), glandular-pubescentes en la cara ventral, con abundantes tricomas glandulares moruliformes con pedículo breve; estambres 3, 2 ditécicos y 1 monotécico, insertados cerca de la garganta del hipanto, parcialmente exertos (sólo la mitad superior); anteras dorsifijas, oblongo-elipsoides; filamento muy corto, glabro o con algunos tricomas dispersos, eglandulares simples, cortos; conectivo hialino, angosto o algo ensanchado, usualmente con escotaduras en ápice y base, a menudo glabro, a veces con algunos tricomas glandulares ampuliformes en el ápice; tecas alantoides o botuliformes, rectas o apenas arqueadas, a veces más pronunciadamente hacia los extremos superior y/o inferior, de dehiscencia longitudinal. Inflorescencia carpelada 1-flora (raro 2-flora), en nudos diferentes a los que portan las inflorescencias maculinas; pedicelo estriado longitudinalmente, hírtulo a hirsuto, tornándose glabrescente y alargándose en el fruto. Flor carpelada ebracteada; hipanto cilíndrico, usualmente más corto que el de las flores estaminadas, exteriormente hirsuto, interiormente lanoso en la garganta; sépalos y pétalos similares a los de las flores estaminadas, estaminodios 4-5, alternipetalos o en posiciones intermedias, mameliformes o subulados con ápice cónico, insertados en la garganta del hipanto; ovario angosta a anchamente elipsoide, hírtulo a hirsuto o hirsuto-tomentoso (a lanoso en pimpollos), (3-4-)5placentífero, estilo columnar divido apicalmente en 3-5 ramas poco notables; estigmas 2lobulados, con lobulos usualmente en forma de "U", a veces obscuramente y subglobosos, papilosos; óvulos numerosos, horizontales. Fruto a menudo elipsoide o subesférico, con costillas más o menos pronunciadas, de color verde, más oscuro en las costillas, tornándose amarillentos a anaranjado pálido al madurar, esparcidamente piloso, mesocarpo carnosofibroso, blanquecino. Semillas anchamente elipsoides a suborbiculares u ovado-elípticas, marcadamente comprimidas, de superficie lisa, opaca, de color castaño claro a oscuro, con una banda blanco cremoso o pajizo en el borde sagital, con margen apenas notable en relieve; saco ariloide mucilaginoso. 
El género Cucurbitopsis, escindido en este trabajo de Apodanthera, cuenta con 3 especies, todas ellas de zonas áridas de Norteamérica, desde el sur de los Estados Unidos de América hasta el centro-sur de México. Las 3 especies reconocidas en el presente trabajo son muy similares entre sí (como puede verse en la clave de especies provista más abajo) y ocupan hábitats similares, aúnque sus áreas de distribución prácticamente no se superponen (Figura 40). Son reconocidas aquí en forma provisoria, hasta tanto se pueda estudiar mayor cantidad de especímenes y poblaciones naturales; tal vez sólo se trate de variedades de una única especie muy variable.

Etimología. El nombre genérico deriva del latín "cucurbita" = calabaza (además, Cucurbita L. es el género tipo de la familia) y "opsis", sufijo de origen griego que indica "con apariencia de" o "semejanza", aludiendo al aspecto similar entre ambos géneros, en especial con Cucurbita foetidissima Kunth, de América del Norte, como comenta Cogniaux (1877: 39), en ocasión de fundar la sección Cucurbitopsis.

Observación 1. El primero en considerar a Cucurbitopsis como un género independiente de Apodanthera fue R. Martínez Crovetto, como surge de sus anotaciones inéditas guardadas en el Instituto de Botánica del Nordeste (CTES) y de numerosas identificaciones colocadas por este botánico en diversos especímenes de herbario.

Observación 2. Al establecer la sección Cucurbitopsis, A. Cogniaux (1877: 40) describió cuatro especies dentro de ésta, sin indicar a ninguna de ellas como tipo de la sección. Por este motivo, se procede aquí a la designación de un lectotipo (CINB Art. 10.2).

Observación 3. En el estudio filogenético llevado adelante en esta tesis (Capítulo 3) el clado que incluye a las especies norteamericanas de Apodanthera sección Cucurbitopsis, consideradas aquí como un género independiente, es el grupo hermano del género Cucurbitella asperata, un género monotípico sudamericano. Si bien el soporte es poco significativo, ambos géneros son morfológicamente muy similares, compartiendo características de importancia taxonómica, entre ellas: inflorescencia estaminada 1-pluriflora, fasciculiforme; hipanto acampanado a subcilíndrico, villoso interiormente; flor carpelada usualmente solitaria, ovario 5-placentífero; fruto carnoso pluriseminado y semillas comprimidas, lisas y emarginadas; adicionalmente, habitan en ambientes similares, áridos y semiáridos. Se distinguen por el largo del pedúnculo de la inflorescencia estaminada (más breve que el pecíolo de la hoja tectriz en Cucurbitella, más largo en Cucurbitopsis), los zarcillos (simples en Cucurbitella, compuestos en Cucurbitopsis) y los segmentos estigmáticos (lineares en Cucurbitella, 2-lobulados, obscuramente en forma de $U$ en Cucurbitopsis). Un estudio más profundo de ambos taxones, 
que contemple mayor evidencia morfológica y molecular permitiría resolver si se trata de dos géneros independientes o bien, de un único género de distribución anfitropical.

Clave de las especies de Cucurbitopsis

1. Inflorescencias estaminadas 3-11(- $\infty)$-floras; flor estaminada con hipanto de 2,1-4,5 cm de largo (3-4 veces la longitud de los sépalos); láminas enteras o ligeramente 5-lobadas, densamente ceniciento-tomentosas en la cara abaxial

C. undulata

1'. Inflorescencias estaminadas 1-6-floras; flor estaminada con hipanto de 1,1-2,1 cm de largo (ca. 2 veces la longitud de los sépalos); láminas enteras a profundamente 3-5-lobadas, escabrosas en la cara abaxial (tomentosas cuando jóvenes)

2(1'). Frutos de 3,8-8,4 x 2,8-5,5 cm; semillas de 9,5-10,5 x 7-9 mm

C. aspera

2'. Frutos de 2,8-5 x 2,1-3 cm; semillas de 6-7 x 3-4 mm

C. palmeri

1. Cucurbitopsis aspera (Cogn.) Mart.Crov. ex Belgrano, comb. nov. Basónimo: Apodanthera aspera Cogn., Mem. Couronnes Autres Mem. Acad. Roy. Sci. Belgique 27: 43. 1877, "In Mexico: Oajaca, maio 1842 (Liebmann, n 56, in hb. Haun.)". TIPO. Mexico. Oaxaca. Oajaca, May 1842, F. M. Liebmann, Cucurbitaceae No56 (lectotipo, C-22/2010, hoja 2!, aquí designado; isolectotipo, F-667401!). Figura 48.

Apodanthera buraeavi Cogn. Mem. Couronnes Autres Mem. Acad. Roy. Sci. Belgique 27: 44. 1877. "In Mexico (Andrieux, no 175, ann. 1834, in hb. Mus. Paris)." TIPO. México, 1834, G. Andrieux 175 (holotipo, P-751818!). Pro syn., Lira \& Rodríguez Arévalo (1999: 8).

Apodanthera galeottii Cogn. Mem. Couronnes Autres Mem. Acad. Roy. Sci. Belgique 27: 45. 1877, "In Mexico: fleurs jaunes en août; champs stériles de Tehuacan (Puebla), altit. 5500'; Calabaza de Cogote des hatitants (Galeotti, no 1886, in hb. Mus. Paris. et Deless., et $n^{\circ} 1886^{*}$ in hb. Kew)". TIPO. México. Puebla. Champs steriles de Tehuacan, $5500 \mathrm{ft}$, calabaza de coyote des habitans, estaminada fleurs jaunes Août, H. Galeotti 1886 lectotipo, P-751820!, aquí designado; isolectotipo, K-430952!, sub n¹886*). Pro syn., Lira \& Rodríguez Arévalo (1999: 8).

Apodanthera crispa Cogn. Bull. Acad. Roy. Belgique, sér. 3, 14: 352. 1887, "Habitat in Mexico ad San Luis Potosi, ann. 1879 (Schaffner, n. 387 in herb. Berol.).". TIPO. México, ex convalli San Luis Potosí, 1877, J. G. Schaffner 387 [766] (lectotipo, NY!, aquí designado; GH! sub n 766, K! sub n 766). Syn. nov. 
Apodanthera cucurbitoides Lundell. Field \& Lab. 13: 23. 1945, "MEXICO: San Luis Potosi, Charcas, in arroyo bed, July 16, 1934, C. L. Lundell 5296 (type in the herbarium of the Southern Methodist University)". TIPO. México. San Luis Potosí, Charcas, in arroyo bed, 16 Jul 1934, C. L. Lundell 5296 (holotipo, SMU en LL-423!). Syn. nov.

Apodanthera undulata A. Gray var. australis McVaugh. Fl. Novo-Galiciana 3: 493, f. 97. 2001, "ca. $7 \mathrm{~km}$ E of Sayula, road to Cd. Guzmán., 1350 m, Dieterle 3550, MICH, the holotype". TIPO. México. Jalisco: ca. 7 km E of Sayula, road to Cd. Guzmán, 1350 m s.m., J. V. A. Dieterle 3550 (lectotipo, MICH 1005003, hoja B!, aquí designado). Syn. nov.

Hierbas diclino-monoicas, perennes, zarcillosas; raíz tuberosa; tallos anuales hasta de 5,5 mm de diámetro, que se extienden sobre el suelo en forma radiada, estriados o costados longitudinalmente, hirsutos, más abundantemente en las partes jóvenes; entrenudos de 3,4-14 $\mathrm{cm}$ de largo. Hojas largamente pecioladas, ascendentes o erectas desde los tallos rastreros; pecíolos robustos, algo aplanados, de 5,2-10 cm x 2,4-3 mm, estriados longitudinalmente, escabrosos, con abundantes tricomas filiformes algo adpresos y otros más robustos, esparcidos; láminas de contorno suborbicular-reniforme, subenteras o 3-5-lobadas (poco o profundamente), de 1,6-11,5 x 2,4-13 cm, base ampliamente cordada, margen ondulado, subentero a irregularmente dentado o crispado, remotamente denticulado, con hidátodos triangulares de 0,5-1 mm de largo, blanquecinos; láminas ligeramente discolores, escabrosopubescentes en ambas caras, más abundantemente en la cara abaxial (rara vez ambas caras glabrescentes), con tricomas adpresos, blanquecinos, con corona de células accesorias persistentes (que suelen tornarse parduzacas en la cara abaxial) y que confieren más o menos aspereza a la superficie de la lámina según su abundancia, la cara adaxial resulta escabrósula, la abaxial áspera; los lóbulos, cuando presentes, redondeados a obovados u oblanceolados. Zarcillos compuestos, 2(-3)-fidos, rectos en la yema, estriados, pilosos, portazarcillos muy breves, de 1-2 mm de largo. Inflorescencia estaminada fasciculiforme, pedunculada, (1-)2-3(-6)flora, 1 por nudo (excepcionalmente 2); pedúnculo erecto 0 ascendente, estriado longitudinalmente, piloso, tornándose glabrescente, de 7,5-19,5 cm x 1,5-2,5 mm; pedicelos de 1,6-5,4 cm de largo en las flores abiertas, filiformes a más o menos robustos, hirsútulos; flores estaminadas bracteadas; bráctea presente cerca de la base del pedicelo, linear-subulada o lanceolada, de 5-10 mm de largo, margen entero, a menudo algo recurvada, caediza, escabrosa o tomentósula; hipanto usualmente subcilíndrico-infundibuliforme (más raramente subcampanulado), más ancho en el ápice, de 1,1-2,1 cm de largo x 2,5-5 mm de ancho en la parte media y hasta $9 \mathrm{~mm}$ de ancho en la garganta, base atenuada hacia el pecíolo o truncada y redondeada, exteriormente hirsuto o hirsuto-tomentoso (a lanoso en pimpollos), interiormente villoso-lanoso en la zona de inserción de los filamentos estaminales; sépalos subulados, con indumento similar al del hipanto, de 4-14 mm de largo x 1-3 mm de ancho en la base, algo recurvos; pétalos obovados o elípticos, de (1,1-)1,7-3,3(-4,5) x (0,5-)0,7-2,4(3,2) cm, de ápice 
agudo, subobtuso o rendondeado, a menudo apiculado, amarillos, con 3-5 nervios principales (el central bien evidente), cortamente pilosos en la cara dorsal, (densamente en los pimpollos), glandular-pubescentes en la cara ventral, con abundantes tricomas glandulares moruliformes; estambres insertados cerca de la fauce del hipanto y resultando parcialmente exertos (la mitad superior); anteras dorsifijas, filamento muy corto, de 1-2 mm de largo; conectivo hialino, angosto o a veces algo ensanchado, a menudo con escotaduras en ápice y base, glabro o con tricomas glandulares ampuliformes; tecas alantoides o botuliformes, de 5,5-8 $\mathrm{mm}$ de largo, subrectas o apenas arqueadas (a veces marcadamente en el extremo superior), dehiscencia longitudinal. Inflorescencia carpelada 1-flora (excepcionalmente 2-flora), en los nudos distales de los tallos o alternando nudos con inflorescencias estaminadas (excepcionalmente en la misma axila que la inflorescencia estaminada); pedicelo estriado longitudinalmente, hasta de $10,5 \mathrm{~cm}$ de largo, creciendo hasta $16,5 \mathrm{~cm}$ en el fruto, hirsútulo, tornándose glabrescente en el fruto; flor carpelada ebracteada; hipanto cilíndrico, de 4-6 x 5-7 mm, exteriormente hirsuto, interiormente lanoso en la garganta; cáliz y corola similares a las de las flores estaminadas; estaminodios 5, alternipetalos, mameliformes o subulados, de 1,5-2 $\mathrm{mm}$ de largo, insertados cerca de la garganta del hipanto, en la porción lanosa; ovario elipsoide, de 1,5-2,2 cm x 3-9 $\mathrm{mm}$, hirsuto o hirsuto-tomentoso (a lanoso en pimpollos), con tricomas algo ascendentes, 5placentífero; estilo columnar, de 7,5-10 x 2,5 mm, glabro o piloso, con (3-)5 ramas; estigmas 2lobulados, lóbulos en forma de "U" o subglobosos; óvulos numerosos, horizontales. Fruto elipsoide (angosta a anchamente) de 3,8-8,4 x 2,8-5,5 cm, redondeado en ambos extremos, rostrado, liso, con costillas más o menos pronunciadas, de color verde, más oscuro en las costillas, tornándose amarillentos a anaranjado pálido al madurar, esparcidamente piloso a glabrescente, mesocarpo carnoso-fibroso, blanquecino. Semillas anchamente elipsoides a suborbiculares u ovado-elipsoides, marcadamente comprimidas, de 9,5-10,5 x 7-9 mm, superficie lisa, opaca, de color castaño claro a oscuro, una banda blanco cremoso o pajizo en el borde sagital, con saco ariloide hialino que se torna delgadamente papiráceo al secarse.

Distribución geográfica y hábitat. Habita en las sierras y valles centrales de México, desde el estado de Durango, en el centro-norte, hasta el de Oaxaca, en el sur, a elevaciones comprendidas entre 1300 y 2300 m s.m. (Figura 49). Crece tanto en suelos oscuros y profundos como en otros arcillosos, o pedregosos, en laderas o en planicies aluvionales, en arbustales semiáridos, planicies con Opuntia Mill. (Cactaceae), a los lados de las rutas y en terrenos cultivados en barbecho.

Nombres vulgares y usos. "Calabacillo" [Kelly 612 (UC)], "calabacilla hedionda" [Huerta 105 (TEX), Solbrig 4469 (GH, NY)], "meloncillo" [Kelly 704(UC)]. Sus semillas se consumen asadas o tostadas, aparentemente desde épocas precolombinas por cuanto se han encontrado en sitios arqueológicos del estado de Oaxaca (Lira \& Rodríguez A. 1999, 2006; Lira \& Caballero 
2002); también se ha indicado su uso como medicinal, aunque sin especificar su acción terapéutica [Kelly 612, 704 (UC)].

Etimología. El epíteto específico alude a la textura áspera de las hojas.

Fenología. La época principal de floración se da entre junio y septiembre, la de fructificación de septiembre a noviembre (excepcionalmente hasta enero).

Observación 1. Se trata de una especie con gran variación foliar (láminas subenteras a profundamente lobadas) y aspecto de la inflorescencia estaminada (2-flora, con flores largamente pediceladas, a 6-flora, con pedicelos más breves) lo que ha conducido al establecimiento de numerosos binomios, considerados aquí como sinónimos. Se han estudiado numerosos especímenes con estados intermedios en los caracteres antes mencionados, mientras que la morfología de las esctructuras reproductivas no presenta variaciones que justifiquen reconocer a más de una entidad natural.

Observacion 2. En el herbario $\mathrm{C}$ existen 2 hojas de la colección tipo de Apodanthera aspera (Liebmann 56); se elige como lectotipo a la identificada como 22/2010 hoja 2 (CINB, Art. 9.14), ésta se ajusta al protólogo y es la más completa de las dos.

Observación 3. No se conoce la localidad tipo de Apodanthera bureavi. Sousa (1979) indica que el área de colección de G. Andrieux en el año 1834 abarcó el sur de México, principalmente el Estado de Oaxaca. Su itinerario se inició en la Ciudad de México y sus alrededores y desde allí se continuó hacia el sudeste, por el centro del territorio hasta Tehuantepec (en la costa del Pacífico) y luego hacia el norte hasta Minaitlán (en la costa del Atlántico).

Observación 4. En la descripción original de Apodanthera galeottii se indican dos sintipos (Galeotti 1886 y Galeotti 1886*). De acuerdo con lo indicado en el CINM (Arts. 9.9 y 9.10) se designa como lectotipo al espécimen Galeotti 1886 depositado en el Herbario del Museo de París $(P)$, el cual se corresponde perfectamente con el protólogo, al tiempo que indica "Apodanthera Galeottii Cogn." de puño y letra de A. Cogniaux, el autor del nombre. No se encontraron duplicados en Bruselas, donde Cogniaux trabajaba. El ejemplar depositado en Kew $(K)$, numerado como "1886*" seguramente corresponda a un duplicado de aquel en $\mathrm{P}$, y su información de etiqueta es una copia fiel, traducida al inglés; ambos especímenes son idénticos. 


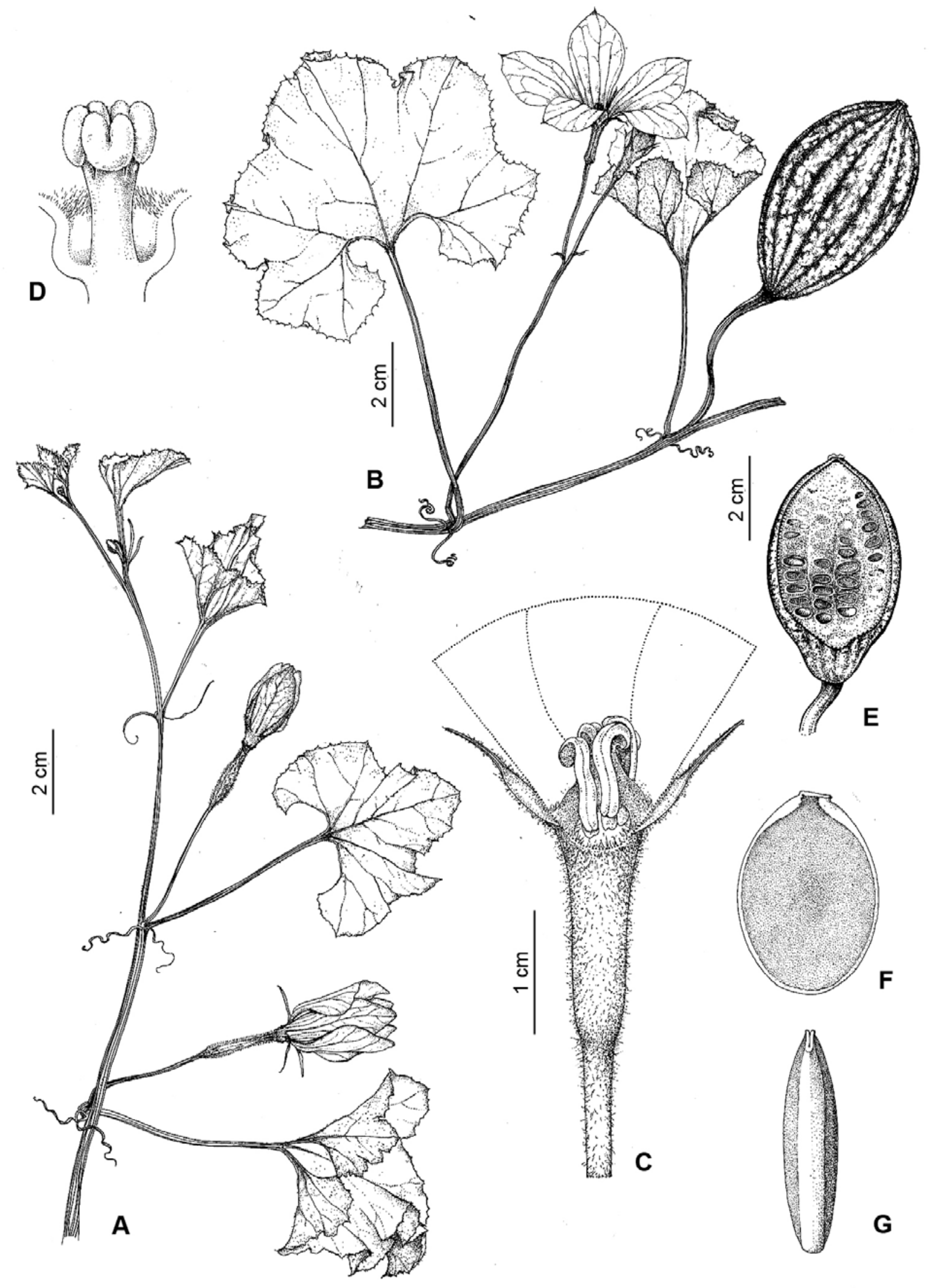

Figura 48. Cucurbitopsis aspera. A. Tallo con flores carpeladas. B. Tallo con inflorescencia estaminada y fruto. C. Flor estaminada, vista lateral, el ápice seccionado deja ver los estambres. D. Detalle de estilo y estigmas. E. Fruto, corte longitudinal. F-G. Semilla. (Tomado de MacVaugh, 2001). 
Observación 5. El tipo de Apodanthera crispa depositado en el herbario de Berlín (B) se ha destruido durante la Segunda Guerra Mundial. Un duplicado de éste, depositado en el herbario del New York Botanical Garden (NY) es elegido aquí como lectotipo. Es necesario aclarar que la fecha de colección indicada en la etiqueta de este ejemplar no se corresponde con la del protólogo (1877 vs. 1879 en el protólogo), probablemente debido a un error durante la preparación de los duplicados. Adicionalmente, cabe destacar que en la etiqueta del lectotipo se indican dos números de colección: 387 y 766.

Observacion 6. En el herbario $\mathrm{MICH}$ existen 2 hojas (A y B) de la colección tipo de Apodanthera undulata var. australis (Dieterle 3550); se elige como lectotipo a la identificada como 1005003 hoja B (CINB, Art. 9.14); ésta se ajusta al protólogo y es la más completa de las dos, con frutos y flores estaminadas.

Observación 7. Se ha reportado que las plantas desprenden un olor algo desagradable [Dieterle 4221 (NY), Solbrig 4469 (GH, NY)].

Material adicional examinado. MÉXICO. Durango. Mun. Canatlan: roadside near Canatlan, 27 Jun 1947, J. Sauer 1019 (UC). Mun. Durango: city of Durango and vicinity, Abr - Nov 1896, E. Palmer 315 (GH, NY, UC). Durango, 6300 ft, 22 Jul 1944, L. Fisher 44176 (NY). Mun. Nombre de Dios: along Hwy. 45, 0,3 mi. S of La Parrilla, 6400 ft, 8 Ene 1977, Wieder et al. 205 (NY). Mun. Tepehuanes: Tepehuanes, 4-25 Jun 1906, E. Palmer 324 (GH, NY, UC). Guanajuato. Mun. Dolores Hidalgo: near Dolores Hidalgo, 10 Ago 1947, L. A. Kenoyer 1921 (GH). Mun. León: 2 miles north of León, 13 Ago 1961, H. C. Cutler 12081 (MO). E of La Joya, 16 Ago 1957, O. T. Solbrig \& R. Ornduff 4469 (GH, NY). Mun. San Miguel de Allende: between La Presita and El Fraile Dams road from San Miguel de Allende to Celaya, 26 Jun 1963, S. K. Harris 25724 (GH). Hidalgo. Mun. Metztitlán: at head of descent into Barranca de Metztitlán, between Zoquital and Los Venados, 2000 m s.m., 19 Jun 1947, H. E. Moore 3099 (GH, US). Between Cerro Colorado and head of descent into Barranca de Metztitlán on road from Pachuca to Zacualtipan, 2000 m s.m., H. E. Moore \& C. E. Wood Jr. 4190 (UC). Jalisco. Mun. Gudalajara: Gualadajara, Ago, E. Palmer 281 (GH, NY). Mun. Huejuquilla el Alto: Huejuquilla, 24 Ago 1897, J. N. Rose 253 (US). Mun. Jalostotitlan: 35-65 miles SW of Lagos de Moreno, 23 Ago 1953, W.E. Manning \& M. S. Manning $531280(\mathrm{GH})$. Mun. Tlajomulco: al SO de San Sebastián, Fracc. Jardines de Verano, 1500 m s.m., 16 Jul 1991, M. Huerta \& G. Lucano 105 (TEX). Mun. Yahualica de González Gallo: near bridge across the Río Verde on the Yahualica to Guadalajar road, 2 Jul 1947, J. Sauer 1053 (UC). Mun. Zacoalco de Torres: about 4 miles from Zacoalco, amid gras son side of causewayto Acatlán, 1350-1375 m s.m., 15 Sep 1969, J. V. A. Dieterle 3427 (NY, TEX). Michoacán. Mun. Morelia: vicinity of Morelia, Punguato, 2100 m s.m., 20 Jun 1912, G. Arsène 8301 (GH, NY, US). Nayarit. Mun. Ixtlan del Río: about 1 mile southwest of 
Ixtlan del Río, 19 Jul 1961, H. C. Cutler 12054 (MO). Oaxaca. Mun. San Juan Bautista Coixtlahuaca: 1 km al O de Coixtlahuaca, 2100 m s.m., G. Abisaí et al 2514 (F). Mun. Santa María Colotepec: Los Naranjos, Jul 1908, C. A. Purpus 3551 (UC, NY). Mun. Oaxaca: Monte Albán near Oaxaca, 20 Jul 1947, C. Conzatti et al. 17M443 (LIL-388186). Mun. Tlacolula de Matamorros: along Mex. Hwy. 190 toward Tehuantepec, ca. 4 km WNW of turn-off to Tlacolula, 1700 m s.m., 28 Nov 1971, J. V. A. Dieterle 4221 (NY). Puebla. Mun. Puebla: in ditione de Puebla, Abr 1834, G. Andrieux 368 (GH). Mun. Tehuacán: El Riego, Ago 1905, J. N. Rose \& J. H. Painter 9895 (GH, NY). Tehuacán, Abr 1911, C. A. Purpus 3550 (GH, UC), 6243 (GH, NY). Querétaro. Mun. Cadeyreta de Montes: Cadereyta, 27 Jul 1952, I. Kelly 704 (UC). Mun. Ezequiel Montes: Ezequiel Montes, 31 May 1952, I. Kelly 612 (UC). Hacienda "El Ciervo", 20 Ago 1905, J. N. Rose et al. 9655 (NY). Mun. Querétaro: between San Pablo and Cadereyta, 25 Ago 1905, J. N. Rose et al. 9838 (NY, US). San Luis Potosí. Mun. San Luis Potosí: 10 miles E of San Luis Potosí along road to Rí Verde, 18 Jul 1963, A. Gentry et al. 20197 (US). Zacatecas. Mun. Guadalupe: entronque Aguascalientes-San Luis Potosí, por la carretera San Luis Potosí Zacatecas, 2320 m s.m., 28 May 1977, M. González s.n. (F). Mun. Miguel Auza: La Honda, 19 Ago 1890, C. G. Pringle 3501 (GH).

2. Cucurbitopsis palmeri (S. Wats.) Mart.-Crov. ex Belgrano, comb. nov. Basónimo: Apodanthera palmeri S. Wats., Proc. Amer. Acad. Arts 24: 50. 1889, "Plains about Guaymas. (282.)". TIPO. México, plains about Guaymas, Oct 1887, E. Palmer 282 (holotipo, GH-31798!; isotipos, BM-92248!, K-430953!, NY-172321!, NY-172322!, US49874!, US-49875!).

Apodanthera roseana Cogn., Contr. U. S. Natl. Herb. 3(5): 317. 1895. “Dr. E. Palmer. No. 1444. Ymala, August, 1891". TIPO. México. Ymala, 16-25 Ago 1891, E. Palmer 1444 (holotipo, BR-649270!; isotipos, F-51965!, GH-31800!, NY-172323!, US-235099!). Syn. nov.

Hierbas diclino-monoicas, perennes, zarcillosas; tallos anuales muy numerosos, emergiendo de tallos perennes subterráneos, hasta de $3 \mathrm{~mm}$ de diámetro, estriados 0 costados longitudinalmente, esparcidamente hirsuto-escabrosos; entrenudos de 2-7 cm de largo. Hojas larga o cortmente pecioladas (usualmente el largo del pecíolo es similar al de la lámina), ascendentes o erectas desde los tallos rastreros; pecíolos robustos, de 1-8 cm x 1-2,3 mm, estriados longitudinalmente, escabrosos, con indumento similar a los tallos; láminas de contorno suborbicular-reniforme, usualmente 3-5-lobadas, más raramente subenteras, de 1,5-9 x 2,2-9,4 cm, base ampliamente cordada, margen algo ondulado, irregularmente dentado, algunas veces algo crispado, remotamente denticulado (hidátodos triangulares), escabrosopubescentes en ambas caras, más abundantemente en la cara abaxial, con mezcla de tricomas 
eglandulares cónicos, unos de base unicelular, otros mucho más abundantes y robustos con corona de células accesorias persistentes (las que pueden tornarse parduzcas y muy notables en la cara abaxial), adpresos; lóbulos, cuando presentes, obovados o anchamente elípticos, con ápice obtuso, algo redondeado, a veces truncado. Zarcillos compuestos, 2-fidos, gráciles, rectos en la yema, estriados, pilosos, portazarcillos muy breves, casi nulos. Inflorescencia estaminada, 1-5-flora, pedunculada, incialmente con aspecto fasciculiforme luego de racimo laxo, 1 por nudo; pedúnculo erecto o ascendente, finamente estriado, esparcidamente pilósulo, tornándose glabrescente, hasta de de $8 \mathrm{~cm}$ de largo; pedicelos filiformes, de 0,5-5 cm de largo en las flores abiertas, hirsútulos, algo más notablemente hacia el ápice. Flores estaminadas bracteadas; bráctea filiforme a linear-lanceolada, en la base del pedicelo, ca. 5 $\mathrm{mm}$ de largo, margen entero, a menudo algo recurvada, fácilmente caediza, esparcidamente hirsútula; hipanto subcilíndrico-infundibuliforme, más ancho en el ápice, de 7-12 mm de largo x 4-8 $\mathrm{mm}$ de ancho en la garganta, base atenuada hacia el pecíolo o redondeada, exteriormente hirsuto, con tricomas robustos algo arqueado-ascendentes, interiormente villoso en el tercio superior, en la zona de inserción de los filamentos estaminales; sépalos linear-subulados, con indumento similar al del hipanto, de 4,5-7 mm de largo, algo recurvos; pétalos elípticos u obovado-elítpicos, subiguales, de 1,8-2,4 x 0,9-1,4 cm, de ápice agudo, apiculado, amarillos, con 3 nervios principales (el central bien evidente), cortamente pilosos en la cara dorsal, glandular-pubescentes en la ventral, con abundantes tricomas glandulares moruliformes; estambres insertados cerca de la fauce del hipanto y resultando parcialmente exertos; anteras dorsifijas; filamento muy corto, de 1-2 mm de largo; conectivo hialino, angosto o algo ensanchado, a menudo con escotaduras en ápice y base, glabro; tecas alantoides o botuliformes, de 4,5-6,5 mm de largo, subrectas, a veces algo flexionadas en el extremo superior y/o inferior, de dehiscencia longitudinal. Inflorescencia carpelada 1-flora, pedicelada; pedicelo estriado longitudinalmente, ca. $1 \mathrm{~cm}$ de largo, creciendo hasta 6 cm durante la fructificación, hirsútulo, tornándose glabrescente. Flor carpelada ebracteada; hipanto cilíndrico, breve, hasta de $4 \times 4 \mathrm{~mm}$, exteriormente hirsuto, con tricomas robustos algo arquedo-ascendentes, interiormente villoso en la garganta; sépalos linear-lanceolados, ca. $5 \mathrm{~mm}$ de largo, con indumento como el del hipanto; pétalos angostamente elípticos, hasta de 1,9 x 0,7 cm, densa y cortamente villosos en la cara externa, punteado-glandular en la interna; estaminodios 5, opositipétalos, mameliformes, con ápice algo cónico y redondeado (con forma de colmillo), hasta de $3 \mathrm{~mm}$ de largo, pilósulos, insertados cerca de la garganta del hipanto, en la porción villosa del hipanto, a menudo agrupados de a pares, quedando uno de ellos solitario; ovario elipsoide-fusiforme, hasta de 1,4 $\mathrm{cm} \times 4 \mathrm{~mm}$, hirsuto, con tricomas robustos, incurvos, 4-5placentífero; estilo columnar, hasta de $8 \times 1,5 \mathrm{~mm}$, con 3-5 ramas; estigmas obscuramente 2lobulados, lóbulos en forma de "U" o subglobosos; óvulos numerosos, horizontales. Fruto anchamente elipsoide, de 2,8-5 x 2,1-3 cm cuando maduro, base algo 
atenuada o redondeada, ápice redondeado, con rostro notable, hirsútulo, verde, con líneas verde osucuro y otras blanquecinas, mesocarpo carnoso-fibroso. Semillas ovado-elipsoides, marcadamente comprimidas, de 6-7 x 3-4 mm, superficie lisa, opaca, de color castaño oscuro, con una banda blanco cremoso en el borde sagital, el cual no es marginado, cubiertas por un saco ariloide hialino que se torna delgadamente papiráceo al secarse.

Distribución geográfica y hábitat. Esta especie crece en el noroeste de México, en los estados de Sonora, Sinaola y extremo oeste de Chihuahua (Figura 49). Crece en planicies áridas cercanas al nivel del mar, en el este del golfo de California y en el desierto de Sonora; también presente en el matorral espinoso y en el bosque bajo caducifolio, al oeste de la Sierra Madre Occidental.

Nombres vulgares y usos. "Melón de coyote”, "ha'lu" [Gentry 2357 (GH)]. Los indios guarijios de México utilizan la decocción de sus raíces como digestivo y los frutos inmaduros y tiernos como alimento [Gentry $2357(\mathrm{GH})]$.

Etimología. La especie fue nombrada en homenaje a Edward Palmer (1831-1911), médico y botánico estadounidense de origen inglés, coleccionista del ejemplar tipo de la especie.

Fenología. Se la ha coleccionado en flor y fruto entre julio y octubre.

Observación 1. En la descripción original de Apodanthera palmeri no se especifica en cual herbario está depositado el ejemplar tipo. Sin embargo, se indica aquí como holotipo al depositado en el Gray Herbarium de Chicago $(\mathrm{GH})$ por tratarse de la institución en la que se desempeñaba Sereno Watson, autor del taxón, de acuerdo con la recomendación 9A.4 del CINM.

Observación 2. Cogniaux (1916) colocó a Cucurbitopsis palmeri (bajo Apodanthera palmeri) en la sección Euapodanthera. En la descripción que brinda de la especie aclara que se corresponde con la original de S. Watson, de modo que se presume que Cogniaux no estudió el tipo ni otro material perteneciente a esta especie. Seguramente Cogniaux la incluyó en Euapodanthera porque Sereno Watson indica, en su descripción original, que la especie presenta láminas delgadas; sin embargo esto no es así: en el tipo las láminas son evidentemente gruesas. En concordancia con lo anterior, Jeffrey (1978) aclara que esta especie es parte del mismo complejo que Cucurbitopsis undulata (sub Apodanthera undulata), tal como se refleja en el análisis filogenético realizado en esta tesis. 
Observación 3. En la descripción original de Apodanthera roseana A. Cogniaux no indicó el herbario de depósito del ejemplar tipo; se indica aquí como holotipo al depositado en el herbario del Jardín Botánico de Bruselas (BR), lugar de trabajo del autor del taxón (recomendación 9A.4 del CINM).

Observación 4. Se ha indicado que las plantas desprenden olor fétido [Wiggins 77 (GH, NY)].

Material adicional examinado. MÉXICO. Chihuahua. Guasaremos, Río Mayo, 5 Ago 1936, $H$. S. Gentry 2357 (GH). Sinaola. Mun. Culiacán: Route 15, ca. 33 km northwest of Culiacán (between K 1453 \& 1454), 11 Jul 1966, R. W. Cruden 1044 (GH, UC). Culiacán, 30 Sep 1904, T. S. Brandegee s.n. (UC). Mun. Mazatlán: Yerba Buena, 10 Oct 1904, T. S. Brandegee s.n. (GH, UC). Sonora. Near Gulf of California, 22 Ago 1884, C. G. Pringle 49 (GH). Mun. Banámichi: on mesa overlooking Río Sonora to the W. El tren de Nicola, 17 Jul 1978, J. Vaughn 637 (MO). Mun. Carbó: 19 miles south of Carbo, between Nogales and Hermosillo, 26 Ago, 1941, I. L. Wiggins \& R. C. Rollins 77 (GH, NY).

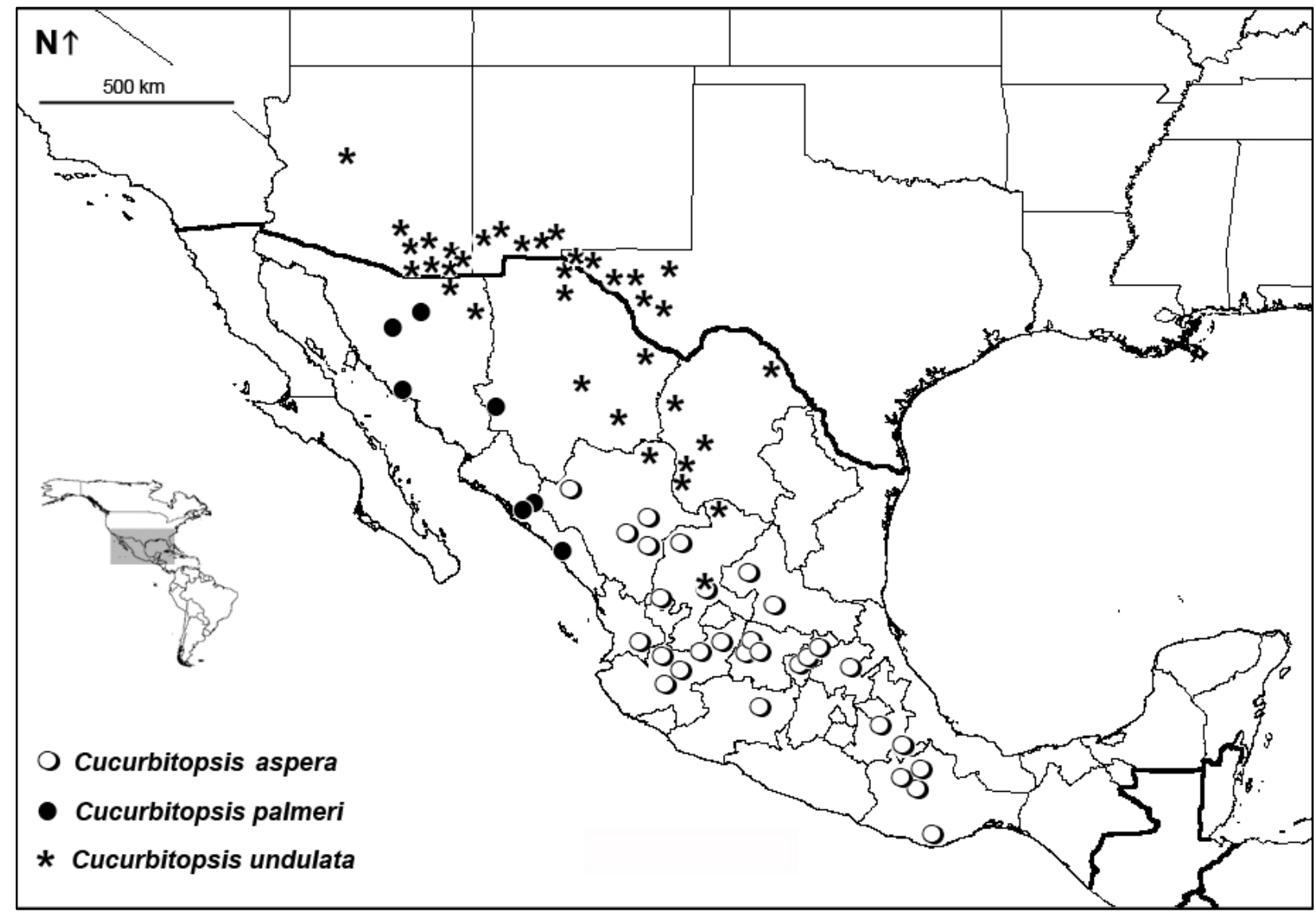

Figura 49. Mapa de distribución de Cucurbitopsis aspera, C. palmeri y C. undulata. 
3. Cucurbitopsis undulata (A. Gray) Mart.-Crov. ex Belgrano, comb. nov. Basónimo: Apodanthera undulata A. Gray, Smithson. Contr. Knowl. 5, Art. 6 [PI. Wright. 2]: 60. 1853, "In valleys from Eagle Springs to the Limpio; June. (1382) (Carrizal, below El Paso, Wislizenus)". TIPO. Estados Unidos de América. Texas. Eaglesprings to Limpio, north Texas, Jun 1851-2, C. Wright 1382 (lectotipo, GH-31797!, aquí desginado; isolectotipos, BM-906032!, G, GH-98101 p.p.!, GH-98102!, K!, MO-5693032!, NY-172318!, P-751823!; PH-3548!, US-47683!, US-47684!). Figuras 50 y 51.

Hierbas diclino-monoicas, perennes, zarcillosas; raíz tuberosa muy engrosada; tallos perennes numerosos, verticales, cortos, subterráneos, de los que emergen tallos anuales postrados, que se extienden sobre el suelo en forma radiada, hasta de 2,5 m de largo y $7 \mathrm{~mm}$ de diámetro, estriados o costados longitudinalmente, densamente pubescentes en las partes jóvenes a esparcidamente pilosas en las adultas, con tricomas eglandulares, blanquecinos, algunos filiformes, algo patentes o subadpresos, con célula apical aguda o subulada, otros más robustos y cortos, con corona de células accesorias persistente, primera célula del pedículo engrosada y célula apical aguda, algo geniculada, caediza, semejando entonces pequeños dentículos; entrenudos de 2-15 cm de largo. Hojas largamente pecioladas, ascendentes o erectas desde los tallos rastreros; pecíolos robustos, algo aplanados, de (3-)6-13 cm x (2-)3-6 $\mathrm{mm}$, estriados longitudinalmente, escabroso-cenicientos, con indumento como el de los tallos pero más denso; láminas suborbicular-reniformes, enteras o ligeramente 3-5-lobadas, de (2,5-) 4-14,8 x (2,5-)5-14,5 cm, base cordada, margen ondulado, a veces irregularmente dentado, remotamente denticulado, con hidátodos triangulares de 1-1,2 $\mathrm{mm}$ de largo, blanquecinos, algo cóncavos adaxialmente, el indumento en ambas caras está compuesto de abundantes tricomas cónicos de base unicelular, entre los que crecen otros más cortos y gruesos, con células accesorias y primeras célula del pedículo persistentes, notablemente discolores, cara adaxial de color verde, escabrósula o algo áspera, con tricomas esparcidos, cara abaxial verdecenicienta, estrigosa o tomentosa, con abundantes tricomas de base unicelular, adpresos, más profusamente sobre los nervios. Zarcillos compuestos, 2(-3)-fidos, rectos en la yema, estriados, pilosos a pubescentes, portazarcillos breves, hasta de $5 \mathrm{~mm}$ de largo. Inflorescencia

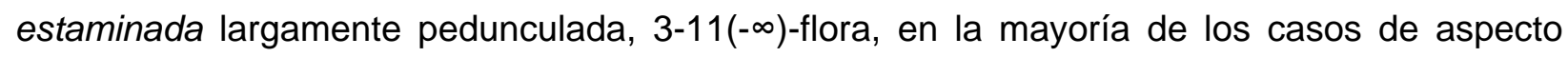
fasciculiforme, otras veces racemiforme, de $12-24,5 \mathrm{~cm}$ de largo, asomando por entre el follaje, 1 inflorescecia por nudo (excepecionalmente 2), comúnmente en los nudos proximales de los tallos, a veces con 1 o varias flores incompletamente desarrolladas; pedúnculo erecto o ascendente, estriado longitudinalmente, ralamente piloso, de 6,5-16 cm x 1,5-3,5 mm; pedicelos de (1-)3-7 cm de largo en las flores abiertas, persistentes; flores estaminadas bracteadas; bráctea presente hacia la base del pedicelo, densamente pubescente, linear o lanceolada, de 1-1,3 cm de largo, con margen entero o apenas denticulado; hipanto largamente subcilíndrico-infundibuliforme, de 2,1-4,5 cm de largo x 3-8 mm de ancho en la parte media y 6- 
$10 \mathrm{~mm}$ de ancho hacia la garganta, el hipanto muestra a menudo un ensanchamiento hacia la base debido a la presencia de un nectario mesenquimático disciforme, craso, exteriormente el hipanto es híspido, ralamente en la parte media, más abundantemente hacia la base y el ápice, con tricomas filiformes o cónicos de base unicelular, interiormente es villoso o lanoso por debajo de los estambres; sépalos angostamente triangulares o subulados, de 7-12 mm de largo $x$ ca. $1 \mathrm{~mm}$ de ancho en la base, a veces algo recurvos, con indumento similar al del hipanto; corola de prefloración imbricada y pétalos de vernación involuta, libres hasta la base, obovados o angosta a anchamente elípticos, de 2,5-4 x 1-2,4 cm, amarillos, con 3-5 nervios principales, corta y densamente pilosos en la cara dorsal, principalmente hacia los nervios y el margen (densamente pubescentes en los pimpollos luego tornándose glabrescentes), glandularpubescentes en la cara ventral, con tricomas glandulares moruliformes; estambres parcialmente exertos, insertados cerca de la garganta del hipanto; anteras dorsifijas, oblogoides; filamento muy corto, de 1-2 mm de largo; conectivo hialino, algo ensanchado, con escotaduras en ápice y base, glabro o con tricomas glandulares ampuliformes en el ápice; tecas alantoides o botuliformes, de 6-8 mm de largo, rectas o apenas arqueadas, más pronunciadamente hacia los extremos superior e inferior, dehiscencia longitudinal. Inflorescencia carpelada 1-flora (excepcionalmente 2-flora), frecuentemente en los nudos distales de las ramas, cuando en la misma rama se desarrollan inflorescencias estaminadas y carpeladas, las primeras en los nudos proximales y las segundas en los distales; pedicelo estriado longitudinalmente, de 1-4,5 cm de largo, luego creciendo hasta $9 \mathrm{~cm}$ en el fruto, hispídulo, con tricomas delgados; flor carpelada ebracteada; hipanto cilíndrico, hasta de $1 \mathrm{~cm}$ de largo, hispídulo; cáliz y corola similares a los de las flores estaminadas; estaminodios 5, alternipetalos, subulados o cilíndricos con ápice cónico, de 1,5-2 mm de largo, insertados en la garganta del hipanto, esa porción del hipanto con pubescencia villosa o lanosa; ovario angostamente elipsoide a elipsoide, densamentente hispídulo, de 1,5-2,1 x 0,6-1,4 cm, 3(-4)-5 placentífero; estilo columnar, algo más ancho en la porción superior, de 7-17 x 3-5 mm, glabro, con 3-5 ramas breves; estigmas 2-lobulados, lóbulos carnosos, papilosos, en forma de "U". Fruto elipsoide a subesférico, de 5-10 x 4,2-7 cm, liso, con costillas más o menos pronunciadas, de color verde, más oscuro en las costillas, tornándose amarillentos a anaranjado pálido al madurar, esparcidamente piloso o hispídulo, mesocarpo carnoso-fibroso, blanquecino. Semillas elipsoides, fuertemente comprimidas, de 7-12 x 5-13 mm, de superficie lisa, opaca, de color castaño claro a oscuro, con una banda blanco cremosa en el borde sagital, no marginadas; saco ariloide mucilaginoso, se torna papiráceo cuando seco.

Distribución geográfica y hábitat. Habita desde el sur de los Estados Unidos de América, en el sur de los estados de Arizona y Nuevo Mexico, donde es muy abundante, y el extremo oeste de Texas, hasta el norte y centro de México, en los estados de Sonora, Chihuahua, Coahuila, Durango, y hacia el sur hasta Zacatecas, donde es menos frecuente (Figura 49). Crece en 
suelos arenoso-rocosos o franco-arcillosos, en planicies aluvionales con cenizas volcánicas, a veces con material metálico en la denominada "Zona del Silencio" en el bolsón del Mapimí; también crece en áreas cultivadas o modificadas, al costado de rutas y caminos, siempre en ambientes xéricos, en elevaciones entre 1000 y 2100 m s.m. La vegetación predominante según la región va desde arbustales dominados por Larrea Cav. ("gobernadora", de la familia Zygophyllaceae) a pastizales abiertos, en planicies y laderas de pendientes suaves, con Acacia Mill. ("huizache", Fabaceae) o Prosopis L. (Fabaceae).

Nombres vulgares y usos. "Melón di Coyoti" (Sonoriano); "melón de coyote" (White 919, GH); "calabaza hedionda", "calabaza loca" y "calabaza amarga" (Lira \& Caballero 2002). Se ha indicado sus semillas se consumen asadas o tostadas y que la pulpa machacada de sus frutos se emplea para curar padecimientos urinarios (Lira \& Rodríguez A. 2006).

Etimología. El epíteto específico alude al margen ondulado de las hojas.

Fenología. Encontrada en flor y fruto entre mayo y octubre.

Observación 1. Se ha indicado que las plantas poseen olor desagradable [Kearney 14852 (US), Johnston 8136 (GH), 1243 (GH), Hitchcock 6781 (UC), McDougal 791 (US), Ecker 7379 (NY), Marazzi, com. pers.)].

Observación 2. Existen 3 hojas de la colección C. Wright 1382 en el Gray Herbarium (GH), uno de los dos sintipos de Apodanthera undulata. McVaugh (FI. Novo Galiciana 3: 493. 2001) señaló a este ejemplar como el tipo de la especie pero sin designar un lectotipo. La hoja con código de barras GH-31797 es designada aquí como lectotipo, de acuerdo a lo estipulado en el CINM (Art. 9.14). Esta hoja se corresponde con la descripción original e indica, de puño de Asa Gray, "n. sp.", característico al designar sus nuevas entidades.

Material adicional examinado. ESTADOS UNIDOS DE AMÉRICA. Arizona. 1869, E. Palmer s.n. (NY). Dutch Charley's Ranch, near Monument 88, 13 Ago 1893, E. A. Mearns 1853 (US). Pedregosa Mts., Mex.Bound.Lim., 12 Sep 1892, E. A. Mearns 846 (US). Cochise Co.: Santa Rita Mountains, east flanks foothills, 1.4 miles west of State Highway 83 on Forest Service Road 62, 1554 m s.m., 28 Jul 1993, L. Ecker \& W. Hodgson 7379 (NY). On the Mesa, Santa Rita Mountains, 28 Sep 1880, G. Engelmann s.n. (MO). Fort Huachuca, Oct 1892, J. E. Wilcox s.n. (NY). At opening of Cave Creek Canon, 26 Sep 1944, 5000', F. A. Barkley 14A886 (MO, UC). 5 miles of Douglas on road to Bisbee, 4100', 1 Jul 1928, C. B. Wolf 2539 (GH). Dos Cabezas, Sep 1891, D. McDougal 791 (US). South of Bisbee, 14 Sep 1892, E. A. Mearns 890 (NY). 5 miles S of juntcion of State highways 90 and 92, 9 Oct 1961, A. S. Barclay 1178 (LL, 
US). Chiracahua Mountains, along the road to Rucker Canyon that heads south from the intersection of Arizona 181 and the Turkey Creek road, 9 Sep 1984, J. Grimes et al. 2597 (NY, TEX). Niggerhead Mts, near Monument no. 82, 15 Ago 1893, E. A. Mearns 1882 (US). Sulpher Springs Valley (W of Chiricahua Mts.), 15 miles SW of Chiricahua National Monument on Highway no. 181, 4000', 5 Oct 1942, C. B. Wolf \& P. C. Everett 11390 (LIL, UC). Luna Co.: Florida, 27 Ago 1895, I. Mulford 1057 (MO). Pima Co.: Tucson, 9 Ago 1903, Homberg 204 (MO, NY, UC). Near Tucson, 7 Sep 1884, C. G. Pringle s.n. (GH, NY, US). 9 miles east of University of Arizona, 22 Sep 1900, D. Griffiths 1627 (NY). Near Fort Lowell, 15 Sep 1900, D. Griffiths 1591 (NY). At mouth of Canyon del Oro, Sta. Catalina Mts., 21 May 1881, Lemmon Herb. 180; 2709 (UC). The Basin, Santa Catalina Mts., 3 Ago 1916, J. A. Harris C16458 (US); 7 Ago 1916, J. A. Harris C16489 (US). Tumamoc Hill, Tucson, 24 Jul 1916, J. A. Harris C16364 (NY, US). Near Route 83, 23 miles south of the Benson highway junction, 12 Ago 1947, 5000', F. W. Gould \& L. R. Gillogly 4380 (UC). Rincon Ranger Station, 3200', 27 Jul 1909, J. C. Blumer 3257 (UC). Vail, 23 May 1928, R. H. Peebles 5301 (US). Tucson, 11 Oct 1894, J. W. Toumey s.n. (UC). Pinal Co.: Florence, 13 Jun 1892, J. W. Toumey 174 (US). Santa Cruz Co.: Near Nogales, 25 Ago 1940, T. H. Kearney \& R. H. Peebles 14852 (US). Yavapai Co.: Hassagampa Creek, south of Prescott, 7 Ago 1865, E. Coues \& E. Palmer 155 (MO). New Mexico. Doña Ana Co.: Organ Mountains, 15 Jul 1897, E. O. Wooton 148 (NY). Organ Mountains, Organ Pass, 18 Jul 1901, E. O. Wooton s.n. (US). 18 miles east of Las Cruces on hwy 70-82, 14 Jun 1974, L. C. Higgins 8710 (NY). Potrillo Mts., West Potrillo Mts., Guzman's Lookot Mtn., south side, 1400 m s.m., 23 Ago 1986, R. D. Worthington 14701 (NY). Grant Co.: Mangas Valley, 8 Ago 1902, E. O. Wooton s.n. (US). The Mimbres, 1851, J. M. Bigelow s.n. (NY). Texas. Ft. Davis - Alpine, 5 Jul 1931, E. Whitehouse s.n. (TEX). Brewster Co.: Sunny Glenn from Alpine, 26 Jul 1938, B. H. Warnock s.n. (GH). South of Alpine, 4900', 16 Jun 1935, T. L. Steiger 604 (NY). Terlingua highway 3 miles south of Alpine, 4600', 16 Jun 1948, B. H. Warnock 7852 (LL). Alpine, 20 May 1928, E. J. Palmer 34031 (NY). Alpine, 16 Jun 1935, T. L. Steiger 1378 (NY). Culberson Co.:

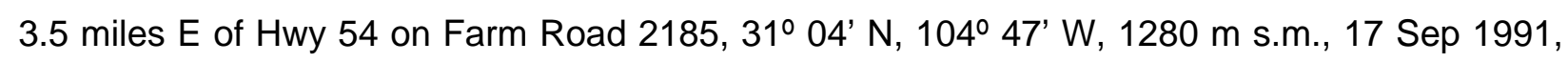
R. D. Noyes \& A. Brant 228 (MO). 191/2 miles SE of Van Horn, 15 May 1946, V. L. Cory 53036 (NY, UC). 2 miles southwest of Van Horn, 3 Jul 1943, T. Waterfall 4898 (MO, NY). 1 mile south of Van Horn, 25 Jun 1940, C. L. Hitchcock \& L. R. Stanford 6781 (NY, UC). 6 miles North of Van Horn along highway 54, 4010', 24 May 1988, L. C. Higgins 17658 (NY). 20 miles W of Joyah, 20 Oct 1938, H. B. Parks 30818 (GH). East of Van Horn, 4000', Sep 1933, T. L. Steiger 406 (NY). Route \#80, 1 mile east of Van Horn, 24 Jul 1957, D. S. Correll \& I. M. Johnston 18448 (GH, UC). Flats near Van Horn, 7 Jul 1900, H. Eggert s.n. (MO). US-290, 3 miles E of Van Horn, 29 May 1967, J. Mearns 1571 (TEX). 2 rd. Miles S of Van Horn by hwy. US-90, 4100', 2 Jun 1984, R. D. Worthington 12022 (NY). El Paso Co.: West of the Hueco Mountains, vicinity of Martin Canyon and Fourmile Draw, 31 $47^{\prime}$ N, 106 02' W, 4350', 18 Oct 1983, A. C. Sanders et al. 4060 (TEX). Lower MCKelligen Canyon, Franklin Mts., 4200', 3 Sep 1951, B. H. Warnock 10108 
(LL). 18 miles eats of El Paso, 15 Sep 1947, H. R. Reed 242 (NY). Hueco Tanks, 20 Jul 1946, A. Lee et al. 46173 (NY, UC). 13 miles east of El Paso, 11 May 1946, V. L. Cory 52919 (NY). 12 3/4 miles north of El Paso, 13 May 1946, V. L. Cory 52987 (NY, US). Hudspeth Co.: Carrizo Mountains, 10 miles West of Van Horn, 29 May 1947, B. H. Warnock 4400 (TEX). Finlay Station, 4 Jul 1921, R. S. Ferris \& C. D. Duncan 2462 (NY). Along the Red Light Draw road just east of the Quitman Mountains, 21 Jun 1976, M. Butterwick \& J. Lamb 2806ª (TEX). Jeff Davis Co.: Davis Mts. Fort Davis, 9-12 Jul 1921, R. S. Ferris \& C. D. Duncan 2714 (NY). HO Canyon, Jun 1936, L. C. Hinckley 548 (NY). Davis Mountains, about $1 / 2$ mile west of mouth of Wood Canyon, Geo. Jones Ranch, 1850 m s.m., 26 Ago 1937, L. C. Hinckley s.n. (NY). Pecos Co.: Pecos, Jul 1934, T. L. Steiger 499 (NY). Presidio Co.: Mesa slope above ZH Canyon, Miller Ranch about 12 miles W of Valentine, 20 Jun 1948, C. L. York 48115 (TEX). Valentine, 4400', Ago 1932, T. L. Steiger 1395 (NY). MÉXICO. Chihuahua. G. Thurber s.n. (NY). Carrizal below El Paso, 20 Ago 1846, A. Wislizenus 116 (sintipo de A. undulata, MO-5693031!). Mun. Casas Grandes: 4.5 miles SW of Casas Grandes on Col. Juárez Hwy, 5000', 10 Jul 1997, J. Spencer \& D. Atwood 423 (TEX). Mun. Gran Morelos: Carretas, 19 Ago 1938, S. S. White 919 (GH). Mun. Jiménez: 5 miles east of Cd. Jiménez, 4500', 31 Jul 1939, S. S. White 2155 (GH). Mun. Juárez: $70 \mathrm{~km}$ S of Ciudad Juárez and 4 km W of Mex. Hwy. 45, on Rancho El Kilo, on the north bajadas of Sierra Candelaria, 14 Jul 1981, D. Ward \& R. Spellenberg 81-330 (NY). Mun. Manuel Benavides: Vicinity of Pirámide, about lat. 28 45' N, 11-12 Ago 1941, I. M. Johnston 8136 (F, $\mathrm{GH})$. Coahuila. Mun. Cuatro Ciénagas: Northern part of plateau portion of Sierra de los Alamitos, 11 miles N of Australia, 26 27' N, 102 ${ }^{\circ}$ 19' W, 1500 m s.m., 13 Jun 1975, F. Chiang et al. 7730 (MO, NY). Mun. Francisco Madero: Movano, Jun 1910, C. A. Purpus 4530 (UC). Mun. Guerrero: North end of Bolsón de los Lipanes, between El Almagre and Cerros de Leja, $27^{\circ} 38^{\prime}$ N, 12 Sep 1940, I. M. Johnston \& C. H. Muller 1243 (GH). Mun. Torreón: 11 km northeast of Jimulco, $25^{\circ} \mathrm{N}, 103^{\circ} \mathrm{W}, 2100 \mathrm{~m}$ s.m., 27 Jun 1941, L. R. Stanford 21 (GH, NY, UC). 12 miles S of Jimulco, 4300', 14 Sep 1939, F. Shreve 9406 (US). Durango. Mun. Mapimí: "Zona de Silencio", 63 km al E de Ceballos, 7 Sep 1983, R. Torres et al. 3600 (MO, NY). Mun. Sierra Mojada: about 30 miles south of Sierra Mojada, 23 Ago 1937, F. L. Wynd 767 (NY). Sonora. Jun 1851, G. Thurber s.n. (NY). Mun. Agua Prieta: 3 miles east of Agua Prieta, road to Colonia Morelos, 3900', 7 Ago 1941, S. S. White 3827 (GH). Mun. Álamos: El Álamo, W Magadalena, 22 May 1925, P. B. Kennedy 7035 (UC). Mun. Huachinera: Horconcitos, Arroyo del Salto, 6 Sep 1940, S. S. White $3781(\mathrm{GH})$. Mun. Yecora: $2.1 \mathrm{~km}$ north of Yecora on road to Agua Blanca, 28 23' 33" N, 108 55' 25" W, 1530 m s.m., 15 Jul 1997, A. L. Reina et al. 97772 (TEX). Zacatecas. Riito di Sta. Cruz, 20-22 Jun 1855, Schott III.3 (NY). Mun. Melchor Ocampo: about $1 \mathrm{~km}$ SW of Sierra del Yeso and almost due wst of La Presa de Los Ángeles, 25 $03^{\prime}$ N, $102^{\circ} 22^{\prime} 15^{\prime \prime}$ W, 1400 m s.m., 30 Jun 1973, M. C. Johnston et al. 11523 (NY). 


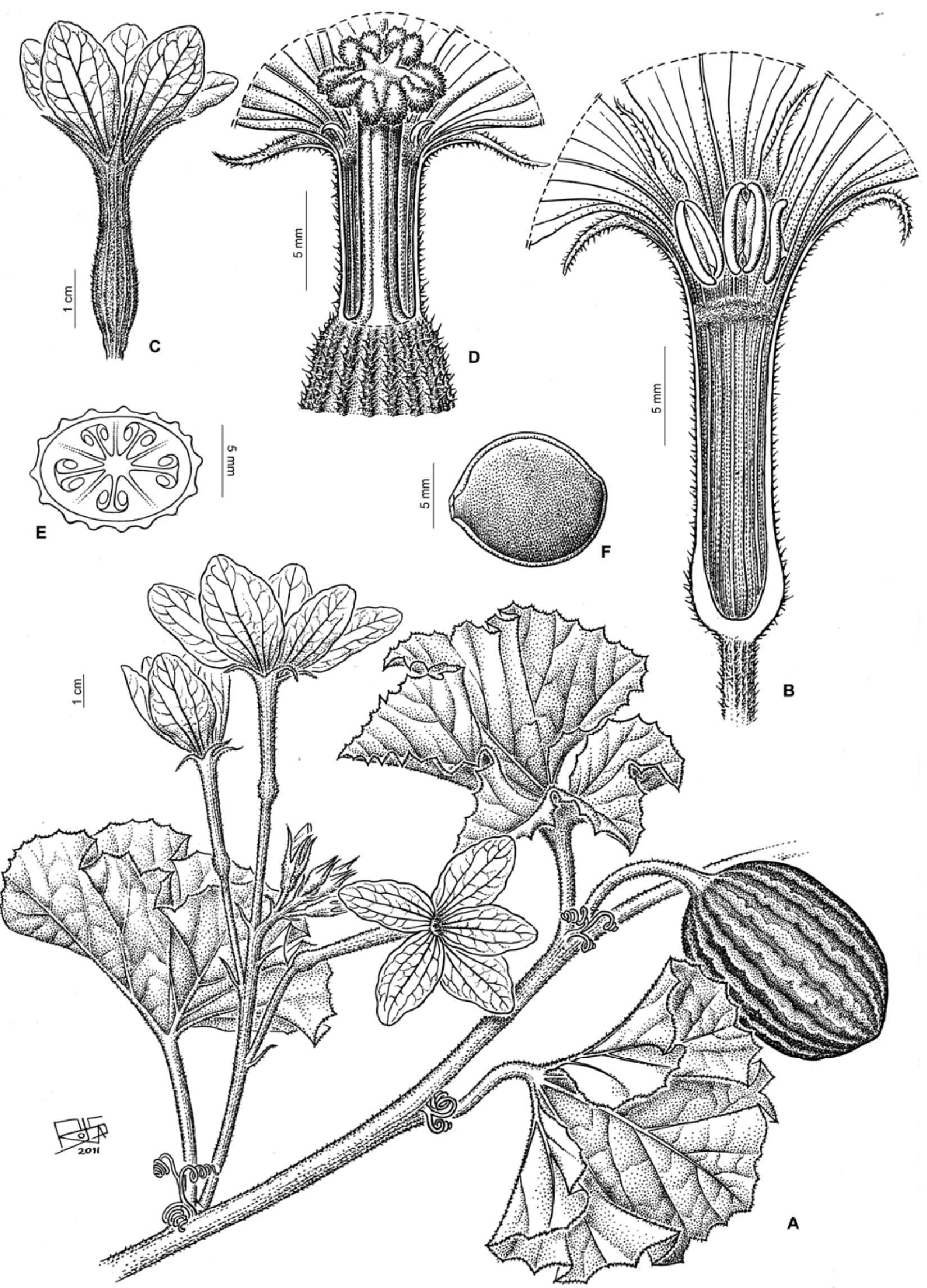

Figura 50. Cucurbitopsis undulata. A. Tallo con inflorescencia estaminada y fruto. B. Flor estaminada, corte longitudinal. C. Flor carpelada, vista lateral. D. Flor carpelada, corte longitudinal del hipanto. E. Ovario, corte transversal. F. Semilla. (Dibujo de F. Rojas, Instituto Darwinion). A de Mearns 846. B y E de Wright 1382. C de Peebles 5301. D de Wolf 2539. F de Johnston 8136. 


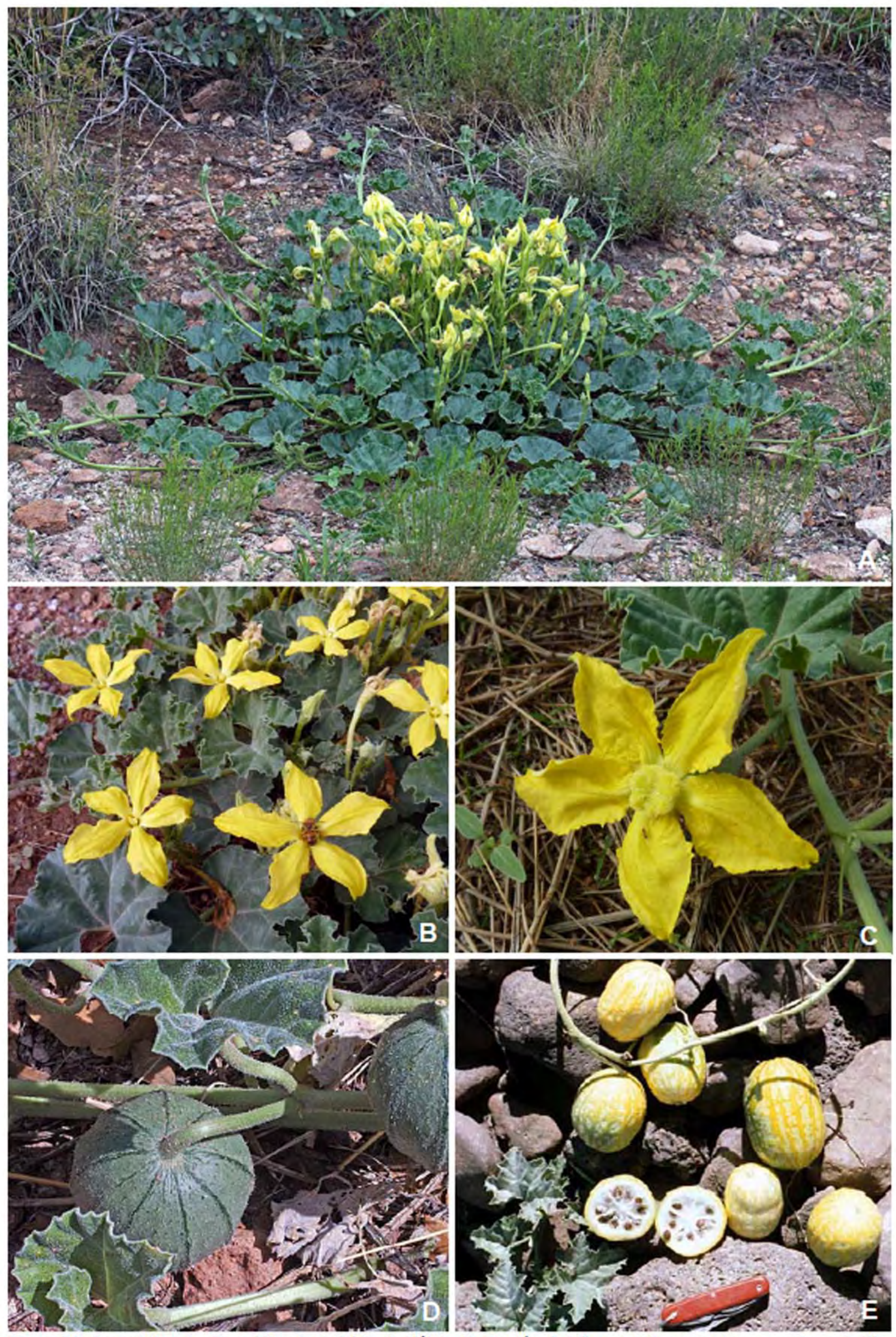

Figura 51. Cucurbitopsis. Cucurbitopsis undulata. A. Hábito. B. Porción de tallo con inflorescencias masculinas. C. Flor carpelada. D. Frutos jóvenes. E. Frutos maduros. (Fotos: A y D, R. Kleinman \& B. Norris, W.N.Mex.Univ.; B -C, Max Licher, Interm.Biota; E, Robert Knight). 
Doyerea Grosourdy, Méd. Bot. Criollo 1(2): 338. 1864. ESPECIE TIPO. Doyerea emetocathartica Grosourdy.

Anguriopsis J.R. Johnst., Proc. Amer. Acad. Arts 40(21): 697. 1905. ESPECIE TIPO. Anguriopsis margaritensis J.R. Johnst. Pro. Syn. Jeffrey \& Trujillo (1992: 35).

Subarbustos diclino-monoicos, zarcillosos; raíces tuberosas, robustas, con la porción apical expuesta sobre la superficie (la tuberización también afecta a la porción basal del tallo), algo cónica, con aspecto de tronco breve; tallos numerosos, subcilíndricos, estriados longitudinalmente (hasta 10 ó 12 costillas poco profundas), inicialmente herbáceos, algo carnosos, puberulentos, con la edad se tornan leñosos, principalmente hacia la base, glabrescentes y adquieren aspecto tortuoso, conspicuamente lenticelados; entrenudos dispuestos más o menos en zig-zag. Hojas pecioladas, las basales enteras, las superiores subenteras, apenas a profundamente 3(-5)-lobadas o 3-folioladas, a menudo caducas al madurar los frutos; pecíolos estriados, pubescentes; láminas de contorno ampliamente ovado, acorazonado o subpentagonal, base cordada, margen subentero, remotamente denticulado (hidátodos), con indumento de tricomas eglandulares de base unicelular, agudos, adpresos, muy abundantes en la cara abaxial, que resulta más blanquecina que la adaxial y tomentosa. Zarcillos simples, robustos, se tornan leñosos, caedizos, con base persistente. Inflorescencia estaminada fasciculiforme, con eje brevísimo, algo carnoso, villoso-lanoso. Flores estaminadas numerosas en cada inflorescencia, ebracteadas, brevemente pediceladas, de color ocre o amarillo verdoso; hipanto obcónico-campanulado exteriormente glabro, interiormente villoso cerca de la fauce; sépalos 5, de vernación valvar, angostamente triangulares o lanceolados, inicialmente erectos, luego recurvos; petalos 5, alternisépalos, de vernación plano-induplicada (bordes y ápice apenas plegados), lanceolados o ensiformes, ápice agudo a obtuso, con 3 nervios más o menos paralelos entre sí, inicialmente rectos y conniventes hacia el centro de la flor, luego algo reflexos, cara dorsal glabra, cara ventral pilosa, con tricomas unicelulares, cortos, de célula apical aguda, algo erectos; estambres 3, 2 ditécicos y 1 monotécico, insertados cerca de la fauce del hipanto, alternipétalos; anteras dorsifijas, oblongo-elipsoides; filamento brevísimo, villoso en la base; anteras botuliformes, rectas; conectivo angosto, apenas expandido en el ápice, glabro o ventralmente piloso. Inflorescencia carpelada cortamente espiciforme, con eje breve, carnoso y densamente villoso-lanoso. Flores carpeladas numerosas, cortamente pediceladas a subsésiles, de color ocre o amarillo verdoso; hipanto muy breve, anular, exteriormente glabro, interiormente villoso cerca de la fauce; sépalos lanceolados o subtriangulares, reflexos o erectos y rígidos; corola similar a la de las flores estaminadas; estaminodios 3, mameliformes; ovario ínfero, elipsoide o subcilíndrico, glabro, 2placentífero; óvulos 8-12 (4-6 por lóculo), horizontales; estilo columnar, glabro, con 2 ramas; estigmas 2-lobulados, lóbulos fimbriado-papilosos. Fruto elipsoide a oblongoide, indehiscente, 
carnoso, base redondeada, ápice truncado, rostrado, inicialmente verde o castaño verdoso, con líneas interrumpidas blancas, rojos cuando maduros, con algunas marcas tenues de color verde pálido, cuando secos algo torulosos. Semillas piriformes, no comprimidas, castaño grisáceo, de superficie rugósula, emarginadas, excepto cerca de la porción hilar donde el margen sagital es más notorio y de coloración más clara; saco ariloide hialino.

Género americano con dos especies, una de ellas, Doyerea emetocathartica posee una amplia distribución, desde México y El Caribe hasta Colombia y Venezuela; la restante, $D$. trifoliata, es endémica del nordeste de Brasil.

Etimología. El género fue nombrado en homenaje al zoologo y agrónomo francés Louis Doyère (1811-1863).

Observación 1. Hasta el presente estudio, se consideraba a Doyerea como un género monotípico de distribución circuncaribe, con $D$. emetocathartica como única especie. En esta tesis se propone la transferencia de Apodanthera trifoliata, previamente ubicada en la sección Pseudoapodanthera, a Doyerea. Ambas especies son muy similares morfológicamente y en la filogenia obtenida en esta tesis resultan agrupadas con soportes muy elevados, ambas especies posee prefloración valvar del cáliz, una sinapomorfía de este género.

Observación 2. Dentro de la tribu Coniandreae, y sobre la base de estudios de filogenia molecular (Kocyan et al. 2007, Shaefer et al. 2009), el género Doyerea es próximo a los géneros americanos Psiguria Neck ex Arn., Gurania (Schltdl.) Cogn. y Helmontia Cogn. En esta tesis, la filogenia combinada lo agrupa con Apodanthera sección Pseudoapodanthera. Distintamente, y en función de sus semillas no comprimidas, Jeffrey (1978) incluyó a Doyerea en un complejo de géneros cuyos límites necesitan ser precisados, entre los que se encuentran Kedrostis Medik. (del Viejo Mundo), Halosicyos Mart. Crov., Ibervillea Greene, Tumamoca Rose y Ceratosanthes Adans. (del Nuevo Mundo).

\section{Clave de las especies de Doyerea}

1. Lámina foliar usualmente ovado-cordada, entera o 3-5 lobada, ocasionalmente más profundamente dividida; sépalos de la flor carpelada lanceolados, reflexos; ovario subcilíndrico, más angosto que el perianto. México, América Central, Caribe, norte de América del Sur, en Colombia y Venezuela

\section{D. emethocatartica}

1'. Lámina foliar 3-foliolada, con folíolos laterales a veces sub 2-lobulados (únicamente las hojas basales son enteras, acorazonadas); sépalos de la flor carpelada subtriangulares con los 
márgenes plegados hacia adentro, erectos; ovario elipsoide, de igual ancho que el perianto o mayor. Nordeste de Brasil

D. trifoliata

1. Doyerea emetocathartica Grosourdy, Méd. Bot. Criollo 1(2): 338. 1864. Corallocarpus emetocatharticus (Grosourdy) Cogn., Bull. Soc. Roy. Bot. Belgique 30(1): 279. 1891, "en las islas de Puerto Rico y en la de Bieques, donde lo hemos recogido". TIPO. Puerto Rico. Guayama, 1864, R. de Grosourdy 13 (holotipo, P-731623!). Figuras 52 y 55A-B.

Doyerea angosturensis Grosourdy, Méd. Bot. Criollo 1(2): 339. 1864. "En los alrededores de Angostura, hoy día ciudad de Bolivar, cabecera de Guyana, República de Venezuela". TIPO. Venezuela, Guyana, Angosture e Ciudad Bolivar, 1864, vulg. raíz de estrella, $R$. de Grosourdy 13 (holotipo, P-731625!). Pro syn., Jeffrey \& Trujillo (1992: 36).

Anguria glomerata Eggers, Fl. St. Croix: 55. 1879. Corallocarpus glomeratus (Eggers) Cogn. Monog. Phan. 3: 658. 1881. SINTIPOS. St. Croix, Jacob's Peak, H. Eggers s.n (sintipo, C). St. Thomas, Picaru Peninsula, H. Eggers s.n. (sintipo, C). Pro syn., Cogniaux (1891: 279).

Anguriopsis margaritensis J. R. Johnst., Proc. Amer. Acad. Arts 40(21): 697. 1905. "Along the roadside from El Valle to San Antonio, climbing over such shrubs as Lycium salsum, R. \& P., and Cereus eburneus, Salm., Johnston, no. 286, Aug. 8, 1903". TIPO. Venezuela. Isla Margarita. El Valle, 8 Ago 1903, J. R. Johnston 286 (holotipo, GH; isotipo, US-532067!). Pro syn., Jeffrey \& Trujillo (1992: 36).

Subarbustos diclino-monoicos, zarcillosos; raíces tuberosas, robustas, con algunas raicillas laterales subterráneas y una porción apical cónica, expuesta sobre la superficie, con aspecto de tronco breve, del que emergen los tallos; tallos numerosos, de varios metros de longitud, inicialmente herbáceos, suculentos y puberulentos, cilíndricos, 10-12 estriados longitudinalmente, verdes con tintes castaños, se tornan glabrescentes, leñosos y conspicuamente lenticelados con la edad en su porción basal, con pequeñas grietas longitudinales. Hojas simples, pecioladas, acorazonadas a ligeramente 3-5-lobadas; pecíolos pubescentes, estriados, de 2-8 cm de largo; láminas de contorno acorazonado a anchamente ovado, de 3-14 x 3-16 cm, base cordada, verdes, más pálidas en la cara abaxial, tomentosa, de borde algo sinuado, usualmente dentado, remotamente denticulado (hidátodos), ápice agudo a obtuso, a menudo cortamente apiculado. Zarcillos simples, robustos, se tornan leñosos, articulados y caedizos, con la base persistente, cónica. Inflorescencia estaminada fasciculiforme, pluriflora. Flores estaminadas numerosas en cada inflorescencia, ebracteadas, cortamente pediceladas, ocráceas (hipanto, cáliz y corola); pedicelos filiformes, hasta de 1,5 
mm de largo, esparcida a densamente puberulentos, persistentes, articulados en el ápice; hipanto obcónico, de 1-1,5 mm de largo, finamente crispado-pubescente en el exterior, en el interior villoso en la fauce; sépalos ovado-lanceolados, agudos, ca. 1,5 mm de largo, margen algo involuto, reflexos hasta la base al madurar la flor, con indumento como el hipanto; petalos lanceolados, de 1-1,5 x 0,5-0,8 mm, inicialmente conniventes hacia el centro de la flor luego reflexos, de color ocre pálido, glabrescentes en la cara externa, pilosos en la interior, con tricomas erecto-ascendentes, blancuzcos; estambres insertados cerca de la fauce del hipanto; filamento brevísimo, subulado, villoso en la base; anteras alantoides, rectas, amarillo brillante; conectivo ligeramente carnoso, apenas extendido en el ápice, ventralmente piloso. Inflorescencia carpelada brevemente espiciforme con eje carnoso y densamente blanco-lanoso, en el fruto brevemente pedunculada (pedúnculo hasta $3 \mathrm{~mm}$ ). Flores carpeladas subsésiles, ocráceas (hipanto, cáliz y corola); hipanto muy reducido, casi nulo; cáliz y corola similares a las de las flores estaminadas; estaminodios 3, dentiformes, desiguales; ovario subcilíndrico, de 2-3 $\mathrm{mm}$ de largo, más angosto que el perianto, glabrescente, lustroso, 2-placentífero; estilo columnar con 2 ramas; estigmas obscuramente 2-lobulados, de superficie papilosa. Fruto elipsoide, algo deformado por la presión de los frutos vecinos, de 8-15 x 4-7 mm, carnoso, base redondeada, ápice truncado, diminutamente rostrado, inicialmente castaño con líneas interrumpidas verduzcas, luego rojizo al madurar. Semillas piriformes, de 3,5-4,9 x 2-3,5 mm y 1,5-2,5 mm de grosor, castaño-grisáceas, blanco-cremoso en el margen sagital, de superficie levemente rugósula, ligeramente marginadas hacia el extremo hilar; saco ariloide translúcido, muy delgado.

Distribución geográfica y hábitat. Especie de amplia distribución circuncaribe, también hacia la costa del Pacífico; se extiende desde el centro-sur de México, por América Central (Belize, Costa Rica, El Salvador, Guatemala, Honduras, Nicaragua), las Indias Occidentales (Puerto Rico, Islas Vírgenes, San Vicente y las Granadinas) y el norte de América del Sur (Colombia y Venezuela) (Figura 53). Habita en planicies bajas, sobre suelos grisáceos, rojizos o negros, formados sobre antiguos basaltos, o bien en laderas pedregosas más elevadas, hasta los 1000 m s.m.

Nombres vulgares y usos. "Kis kaan", "kuum ak", "tuch tunich", "xkabax kaax", "xmakal kaan", "xput kaan", "xta kaan”, "ya'ax kani” (lengua maya, México, Lira 2001); "bejuco de purga", "bejuco de estrella", "raíz de estrella" (Puerto Rico y Venezuela, Grosourdy 1864); "coralillo" (Delascio Ch. \& Reyes L., 2007). En la descripción original (Gosourdy 1864) se indica que de sus tallos se obtiene un amargo incoloro, y que los criollos y curanderos en Puerto Rico lo empleaban diariamente como emético y catártico. En México, diversas partes de la planta se utilizan como antídoto contra la mordedura de serpientes y como emético; las raíces hervidas, 
fritas o machacadas son utilizadas como antiinflamatorio, para aliviar úlceras, como antirreumático y analgésico (Lira 1988; Lira \& Caballero 2002).

Etimología. El epíteto específico hace referencia al uso medicinal que daban a estas plantas los nativos del Caribe, como emético (vomitivo) y catártico (purgante).

Fenología. Florece y fructifica en distintas épocas del año, dependiendo de la ubicación geográfica.

Material adicional examinado. COLOMBIA. Bolívar. Mun. Morales: Norosí, camino a Tiquisio Nuevo, 130-200 m s.m., 9-14 Abr 1985, H. Cuadros V. 2121 (US). EL SALVADOR. Santa Ana. Mun. Metapán: 7 km al sur de Metapán (km 107 de la ruta Santa Ana-Metapan), 14¹6'22"N 88²7'28'W, 650 m s.m., 4 Jun 2004, J. L. Linares 7537 (MO, foto!). NICARAGUA. Chontales. Hacienda Veracruz, $12^{\circ} 11^{\prime} \mathrm{N} 8^{\circ} 21^{\prime} \mathrm{W}, 120-475$ m s.m., W. D. Stevens 22361 (MO, foto!). SAN VICENTE Y LAS GRANADINAS. Las Granadinas. Mayreau, 12³8'N 612ㄱ'W, 2 Ago 2007, C. M. S. Carrington \& K. Sabir 2253 (BAR, foto!).

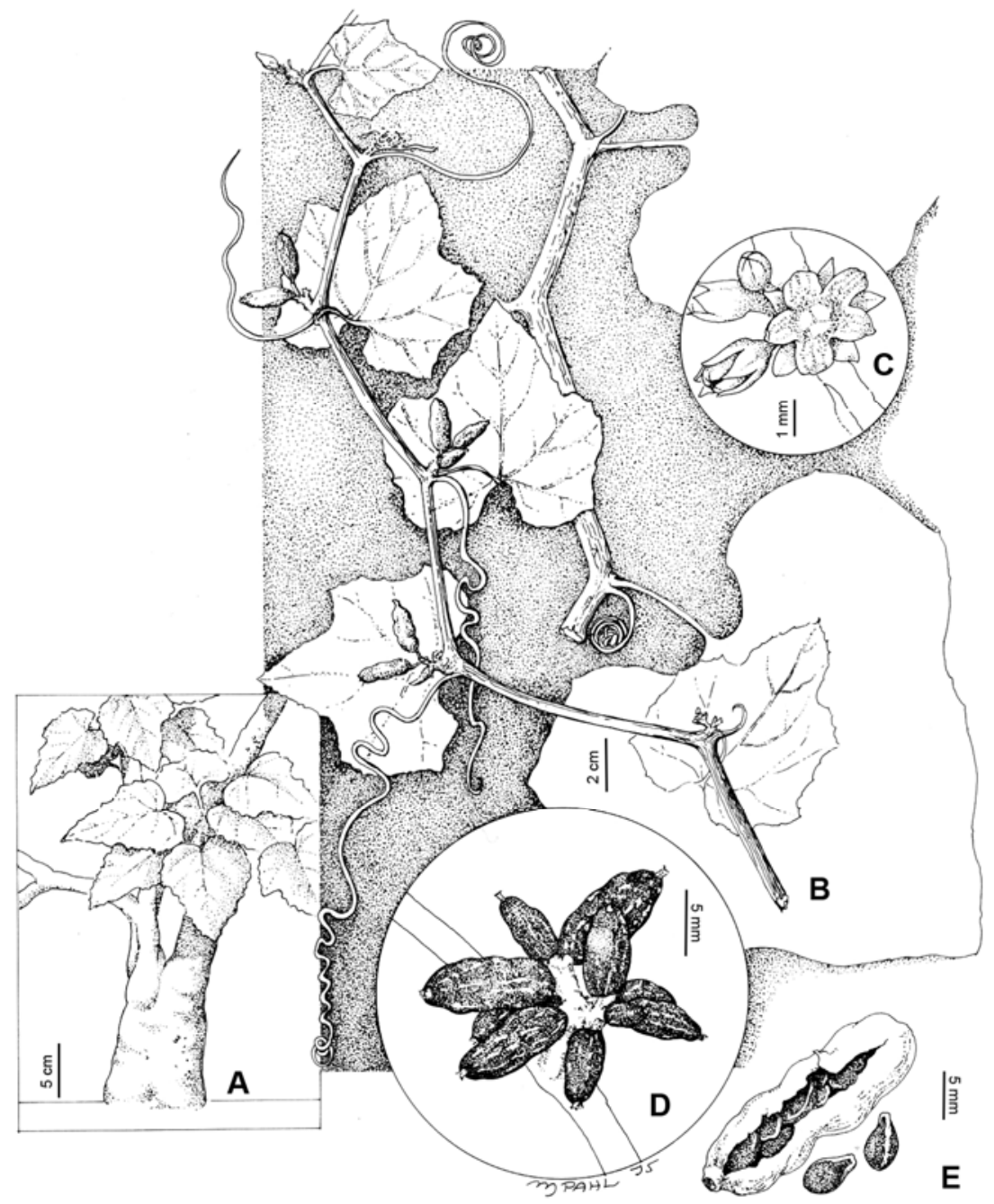

Figura 52. Doyerea emetocathartica. A Porción basal de la planta. B. Porción del tallo con frutos. C. Inflorescencia estaminada. D. Frutos. E. Fruto desgarrado y semillas. (Tomado de Dieterle, 1976). 


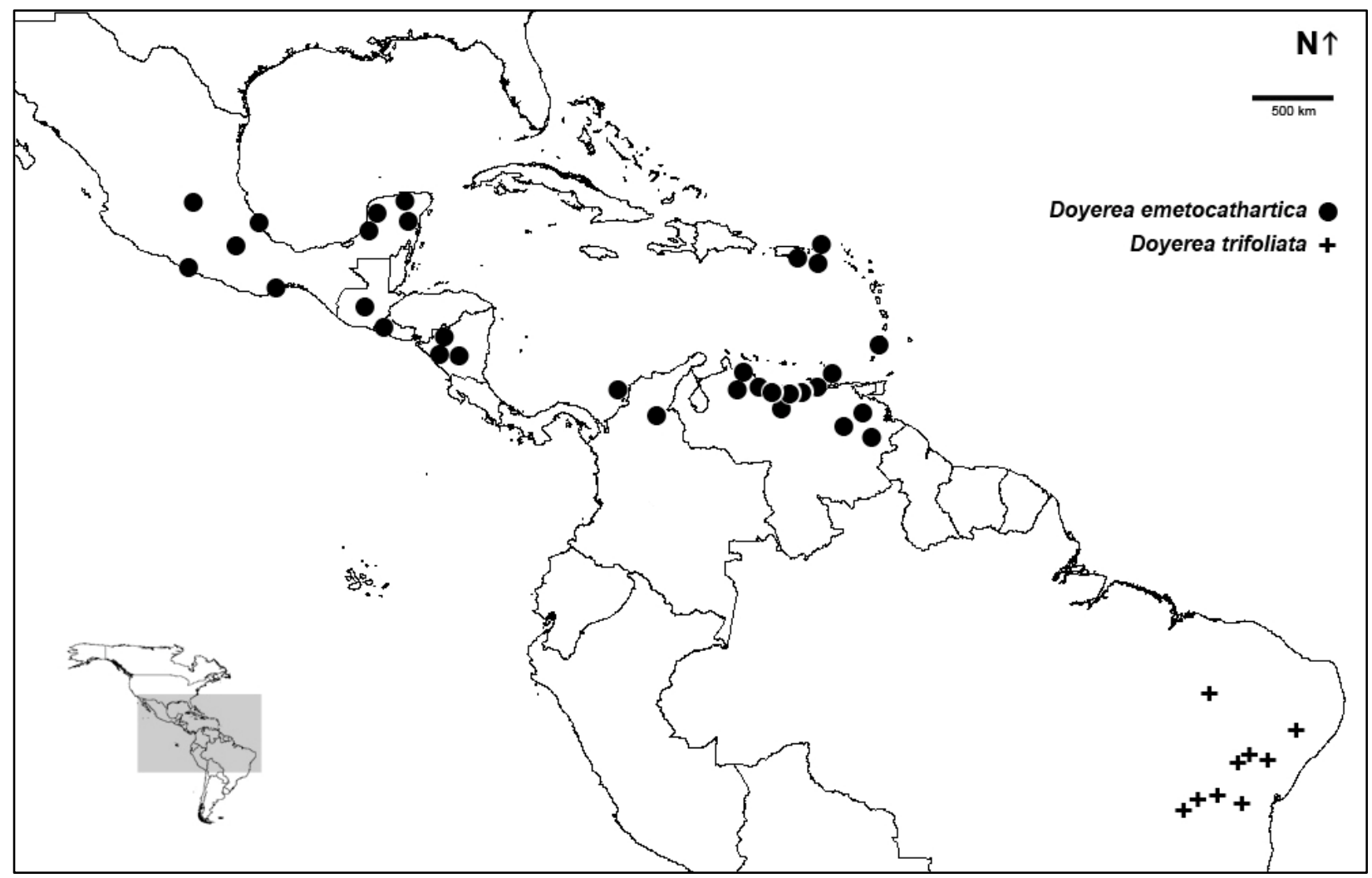

Figura 53. Mapa de distribución de Doyerea emetocathartica y D. trifoliata.

Nota: para ajustar la distribución de Doyerea emetocathartica, adicionalmente a los especímenes indicados en el texto, se tomaron otros registros citados en Jeffrey \& Trujillo (1992), Nee (1993), Lira S. (2001), Acevedo Rodríguez (2005) y los disponibles en la base de datos on-line del Missouri Botanical Garden (www.tropicos.org).

2. Doyerea trifoliata (Cogn.) Belgrano, comb. nov. Basónimo: Apodanthera trifoliata Cogn., Pflanzenr. 66(IV. 275. I): 66. 1916. Melothria trifoliata (Cogn.) Mart.Crov., Notul. Syst. (Paris) 15: 46. 1954 (como trifoliolata). "Südbrasilianische Provinz: Bahia, Catinga bei Calderão (E. Ule n. 7269. - Blühend im Oktober 1906); Prov. Piauhy, Gebüsch in der Serra Branca (E. Uke n. 7570. - Blühend im Januar 1907. - Herb. Berlin)". TIPO. Brasil, in der Catinga bei Caldeirão, Oct 1906, E. Ule 7569 (lectotipo, G, designado por R. Martínez Crovetto, Notul. Syst. (Paris) 15: 47. 1954; isolectotipos, CTES!, fragmento ex G, HBG506433!, L-602750!; foto ex B de la Serie Field Museum Neg. № 8959!). Figuras 54 y $55 \mathrm{C}-\mathrm{E}$.

Apodanthera congestiflora Cogn., Pflanzenr. 66(IV. 275. I): 66. 1916. Melothria congestiflora (Cogn.) Mart.Crov., Notul. Syst. (Paris) 15: 47. 1954. "Südbrasilinische Provinz: Bahia, Catinga Tambury (E. Ule n. 7269b. - Blühend und fruchtend im Oktober 1906. - Herb. Berlin)". TIPO. Brasil. Bahia, Catinga Tambury, Oct 1909, E. Ule 7269b (lecotipo, BR-659 425!, aquí designado, foto ex B de la Serie Field Museum Neg. № 8952!). Syn. nov. 
Subarbustos, diclino-monoicos, zarcillosos; raíces tuberosas, robustas, con la porción apical expuesta sobre la superficie, con aspecto de tronco breve; tallos numerosos, inicialmente herbáceos, suculentos y puberulentos, se tornan leñosos con la edad, glabrescentes y adquieren aspecto tortuoso, conspicuamente lenticelados. Hojas pecioladas, 3-folioladas (sólo las primeras hojas basales son enteras, acorazonadas), las de los nudos fértiles fácilmente caducas al madurar los frutos; pecíolos pubescentes cuando jóvenes, tornándose glabrescentes, de 1,5-8 cm de largo; láminas de contorno anchamente ovado o subpentagonal, de 3,5-14 x 3,2-16 cm, de base cordada, amplia, verdes en la cara adaxial, más pálido o ceniciento en la abaxial, que es tenue o densamente tomentosa; lóbulos cuando presentes de contorno elíptico a anchamente elíptico, algo cuneados en la base, de borde algo sinuado, usualmente dentado, remotamente denticulado (hidátodos), ápice agudo a obtuso, apiculado, el lóbulo central de 2,5-5 x 1,5-2,7 cm, los laterales similares en tamaño, a menudo apenas 2lobulados y asimétricos. Zarcillos simples, robustos, se tornan leñosos, articulados y caedizos, con la base persistente, cónica, ralamente pilosos, con tricomas eglandulares cónicos de base unicelular. Inflorescencia estaminada 1-4 en cada axila, fasciculiforme o brevemente espiciforme con eje carnoso y villoso-lanoso, hasta de $1,5 \mathrm{~cm}$ de largo. Flores estaminadas numerosas (hasta 40 ó más) en cada inflorescencia, ebracteadas, cortamente pediceladas, de color amarillo verdoso; pedicelos filiformes, hasta de $5 \mathrm{~mm}$ de largo, villosos, persistentes, articulados en el ápice; hipanto obcónico, de 1-2 mm de largo x 1,3-2,5 mm cerca del ápice, externamente glabro, internamente villoso en la fauce, con abundantes tricomas eglandulares simples, filiformes, agudos; sépalos subtriangulares a ovado-lanceolados, agudos, de 1-1,7 mm de largo, oscuramente 1(-3)-nervios, glabros en ambas caras, ápice agudo, algo redondeado, ligeramente induplicado; petalos ovado-elípticos a cortamente ensiformes, de 1,5-2 x ca. $1 \mathrm{~mm}$, inicialmente conniventes, luego algo reflexos, ápice agudo, pilosos en la cara interna (tricomas unseriados cortos, agudos), glabrescentes en la externa, con 3(-5) nervios tenues, más o menos paralelos entre sí; estambres insertados cerca de la fauce del hipanto, resultando sus $3 / 4$ superiores exertos; tecas botuliformes, rectas, de 1,5-2 $\mathrm{mm}$ de largo; filamentos brevísimos, villosos cerca del punto de inserción en el hipanto; conectivo angosto, hialino, glabro, cortamente escotado en la base y brevemente expandido en el ápice, sobre cada teca. Inflorescencia carpelada cortamente espiciforme, con frecuencia se observan simultáneamente flores abiertas, otras en pimpollo, frutos inmaduros y otros maduros. Flores carpeladas numerosas (hasta 25 o más), subsésiles, de color amarillo verdoso; pedicelos hasta de $1 \mathrm{~mm}$ de largo (algo mayores en el fruto); hipanto muy breve, ca. $1 \mathrm{~mm}$ de largo, glabrescente en el exterior, villoso en la fauce, interiormente; sépalos subtriangulares, los bordes plegados hacia adentro confiriendo aspecto agudo y rígido, erectos, de 1-1,3 mm de largo; pétalos ensiformeslanceolados, ca. $2 \times 0,7 \mathrm{~mm}$, inicialmente conniventes hacia el centro luego reflexos, glabrescentes en la cara externa, piloso-ascendentes en la interna, con tricomas eglandulares simples, con célula apica aguda; estaminodios 3 , dentiformes o subtriagulares, ca. 0,5 mm de 
largo; ovario irregularmente elipsoide, de 2,5-3 x 1,5-2 mm, base redondeada, apice truncado, glabro, 2-placentífero; óvulos 4-6 en cada placenta; estilo columnar, glabro, ca. 2 mm de largo, con 2 ramas; estigmas exertos, 2-lobulados, lóbulos fimbriado-papilosos. Fruto carnoso, elipsoide de 9-14 x 4-8 mm, base redondeada, ápice truncado, diminutamente rostrado, glabro, inicialmente castaño verdoso, con líneas interrumpidas blancas, anaranjados a rojos cuando maduros, con algunas marcas tenues, verde pálido. Semillas piriformes de 3,5-5,2 x 2,3-3,4 $\mathrm{mm}$ y 1,7-2,6 mm de grosor, castañas, de superficie rugósula, emarginadas, excepto cerca de la porción hilar, donde el margen sagital es más notorio y de tonalidad más clara.

Distribución geográfica y hábitat. Especie endémica del nordeste de Brasil, en los estados de Piauí, Sergipe y Bahia (Figura 53). Habita en ambientes xéricos, en planicies o laderas pedregosas, expuestas, con vegetación arbustiva, rala, en ambientes de Caatinga y en los denominados "campos rupestres" del nordeste de Brasil, hasta los 1000 m s.m. Las plantas crecen aisladas o en grupos, los tallos suelen trepar sobre la vegetación circundante, alambrados, etc., o bien enlazarse entre sí. Las porciones basales de los tallos se hacen leñosas y se mantienen de un año a otro, confiriendo a las plantas un aspecto enmarañado y tortuoso.

Nombre vulgar y usos. "Cabeça de negro" (portugués, Brasil, Cogniaux 1916). En Brasil sus raíces, en infusión o en baño, se emplean como depurativo de la sangre o para combatir manchas en la piel, respectivamente (Roque et al. 2010).

Fenología. Florece y fructifica entre noviembre y abril.

Etimología. El epíteto específico hace referencia a las hojas 3-foliadas, caracterísitcas de este taxón, del latín "tri" = tres y "folium" = hoja.

Observación 1. El tipo de Apodanthera congestiflora depositado en el Herbario de Berlín (B) fue destruido durante la Segunda Guerra Mundial. Por este motivo, se procedió a designar un lectotipo (CINM, Arts. 9.2, 9.9, 9.10). Sólo ha podido localizarse un único duplicado del tipo, depositado en el herbario de BR, y que consta de fragmentos de hojas y algunas flores sueltas. Este ejemplar cuenta con anotaciones y análisis florales de A. Cogniaux, autor del taxón. Al hacer la transferencia a Melothria, Martínez Crovetto (1954b) indicó "Del tipo queda un fragmento conservado en el Jardin Botánico de Bruselas", no pudiéndo considerarse que haya hecho una lectotipificación. 


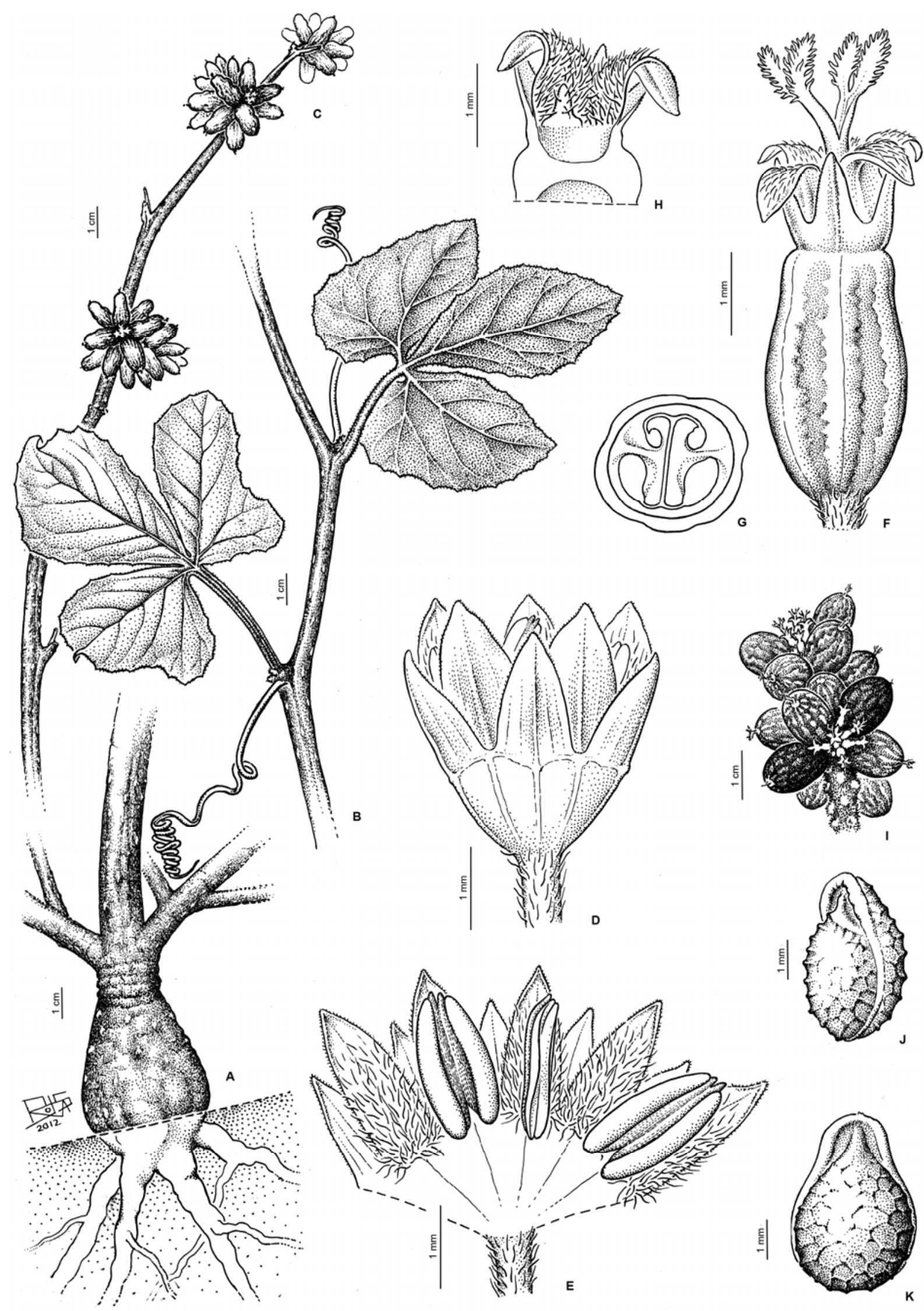

Figura 54. Doyerea trifoliata. A. Tubérculo radical-caulinar (porción superior expuesta). B. Porción de tallo con dos nudos, hojas trifoliadas y zarcillos simples. C. Extremo fructífero de un tallo (las hojas, los zarcillos y el extremo del tallo han caido). D. Flor estaminada, vista lateral. E. Flor estaminada, vista interna. F. Flor carpelada, vista lateral. G. Ovario, transcorte. H. Flor carpelada, corte longitudinal del hipanto, con estaminodios. (Dibujo de F. Rojas, Instituto Darwinion). A-C, F-K de Amorim \& Belgrano 3845; D-E de Rose 19954. 
Observación 2. Esta especie es muy similar a Doyerea emetocatarthica, una especie de amplia distribución geográfica y gran variabilidad foliar. En esta tesis se las acepta como especies independientes en forma preliminar, principalmente por la morfología del ovario (véase la clave de especies). El estudio de un mayor número de muestras permitiría corroborar esta postura o bien que son conespecíficas.

Material adicional examinado. BRASIL. Bahia. Mun. Bom Jesus da Lapa: Basin of the Upper São Francisco River. Fazenda Imbuzeiro da Onça, ca. 8 km from Bom Jesus da Lapa, on by road to Calderão, 1309'S 43²2'W, 500 m s.m., 19 Abr 1980, R. M. Harley et al. 21534 (CEPEC, NY). Mun. Ibotirama: Rodovia (BR-242) Ibotirama-Barreiras km 30, 540 m s.m., 7 Jul 1983, L. Coradin et al. 6575 (NY). Mun. Jacobina: Estrada que liga Jacobina à Morro do

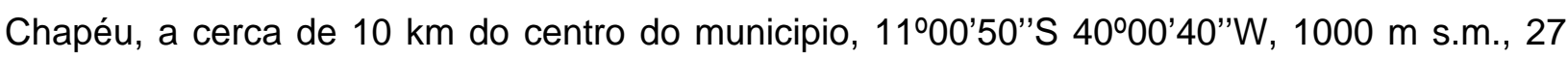
Nov 2003, A. M. Amorim \& M. J. Belgrano 3845 (CEPEC). Ca. 10 km na estrada de Jacobina para Morro do Chapéu, 14 Mar 1990, A. M. Carvalho \& J. Saunders 2797 (CEPEC). Mun. Maracás: vicinity of Machado Portello, 19-23 Jun 1915, J. N. Rose \& P. G. Russell 19954 (US). Mun. Santaluz: ca. 15 km NW de Santaluz, hacia Queimadas, 1109'S 30²7'W, 1 Dic 1992, M. M. Arbo et al. 5497 (CTES, K). Piauí. dans la Serra Branca, Ene 1907, E. Ule 7570 (sintipo de Apodanthera trifoliata, BR-841 199!, HBG-506434!). Sergipe. Mun. Canindé do São Francisco: Fazenda Xingó, perto de Xingozinho, 3 km da divisa com a Bahia, 9³3'48'S 3801'03'W, 25 Abr 2001, R. M. Harley et al. 54296 (CEPEC). 


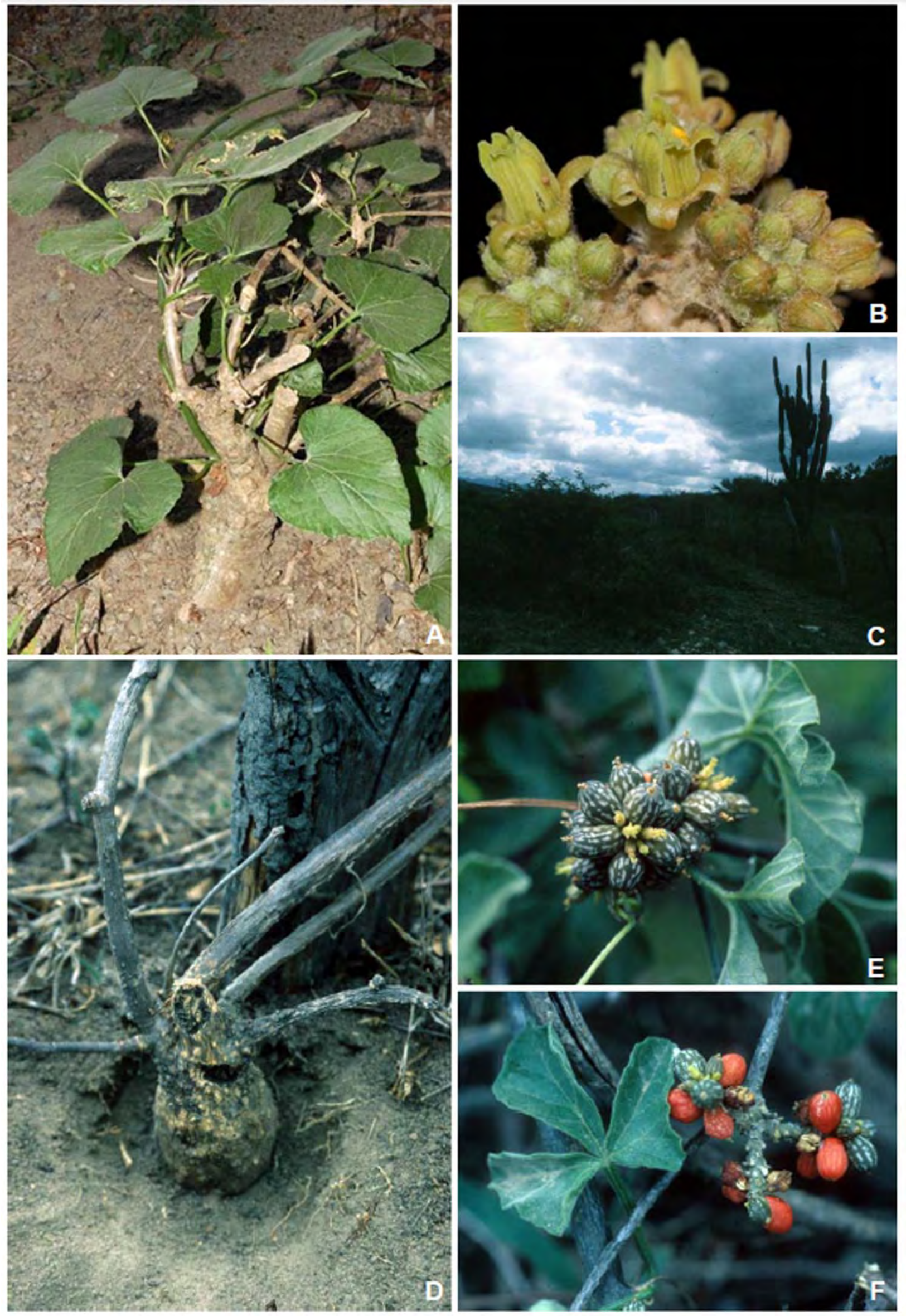

Figura 55. Doyeres. Doyerea emetocathartica. A. Planta, porción basal (foto Missouri Bot. Gard., de Hammel \& Pérez 24997, INB). B. Inflorescencia estaminada (foto Missouri Bot. Gard., de Hammel \& Pérez 25058, INB). Doyerea trifoliata. C. Hábitat: Caatinga, ca. Jacobina (Bahia, Brasil). D. Raiz tuberosa con porción superior expuesta. E. Flores carpeladas y frutos inmaduros. F. Frutos maduros e inmaduros. (Fotos M. J. Belgrano, de Amorim \& Belgrano 3845, CEPEC). 
Melothrianthus Mart.Crov., Notul. Syst. (Paris) 15: 58. 1954. ESPECIE TIPO. Melothrianthus smilacifolius (Cogn.) Mart. Crov. (= Apodanthera smilacifolia Cogn.).

Wilbrandia Silva Manso sect. Melothriopsis Cogn., Fl. Bras. 6(4): 33. 1878. Syn. nov.

Hierbas perennes, diclino-monoicas, zarcillosas. Raíces pivotantes, tuberosas, hasta de varios centímetros de diámetro, con unas pocas raícillas laterales no tuberosas; tallo perenne usualmente uno, subterráneo, breve y leñoso del que emergen cada año 1 a varios tallos anuales subcilíndricos, estriados o surcados longitudinalmente, herbáceos, a veces tornándose sub-leñosos hacia la base, ramificados, glabrescentes o esparcidamente pubérulos, hispídulos, hirsútulos o hirsutos, a menudo más profusamente en las partes jóvenes, con tricomas eglandulares filiformes o cónicos de base unicelular, agudos, patentes o ascendentes. Hojas simples, pecioladas, enteras, lobuladas o sectadas; pecíolos estriados, pilosos, híspidos a densamente hirsuto-villosos, más cortos que la lámina; láminas de contorno acorazonado, ovado-triangular, sagitado, hastado u oblongo-lanceolado, con la base cordada, redondeada o con aurículas subtriangulares y el ápice ápice acuminado o redondeado, margen remotamente denticulado (hidátodos), de consistencia tenuemente membranácea, membranácea o cartácea, ligeramente discolores, de un verde más pálido en la cara abaxial, glabrescentes o pubescentes en ambas caras, a menudo con tricomas cónicos de base unicelular, más profusos en la cara abaxial, adpresos o menos frecuentemente suberectos, muy profusos sobre los nervios. Zarcillos simples, de prefoliación recta, glabrescentes, hispídulos o hirsutos. Inflorescencias estaminadas racemiformes o umbeliformes, laxas o congestas, larga o cortamente pedunculadas; pedúnculo grácil, estriado, rala a densamente hirsútulo o hirsuto; pedicelos filiformes, esparcidamente hispídulos, hirsutos, hirsuto-villosos, tomentosos o lanosos, persistentes, algo recurvos, ligeramente ensanchados hacia el ápice. Flores estaminadas ebracteadas o con una bráctea en la base del pedicelo; brácteas cuando presentes angostamente lanceoladas u ovado-laceoladas, escariosas o foliosas, persistentes o fácilmente caducas; hipanto urceolado-cilíndrico, angostamente campanulado o subcilíndricoinfundibuliforme, ensanchándose levemente hacia el ápice y redondeado en la base, glabrescente, esparcida o densamente hirsuto-villoso, hirsuto-tomentoso o híspido en el exterior, con tricomas eglandulares filiformes, patentes o algo ascendentes, de largo y grosor variables, en el interior es villoso o lanoso-villoso hacia la fauce, con tricomas filiformes entrelazados; sépalos subtriangulares a angostamente lanceolados, con indumento similar al del hipanto; pétalos ovado-elípticos, angostamente elípticos u ovado-lanceolados, enteros o 2lobulados, ápice agudo a subobtuso, induplicado, a veces cortamente apiculado o acuminado, 5-nervios, corta y muy densamente afelpado-pilosos o afelpado-tomentosos en la cara externa, con tricomas uniseriados, simples y cortos, en la cara interna usualmente glandularpubescentes, con tricomas glandulares moruliformes, o más raramente glabrescentes; 
estambres 3, subsésiles, 2 ditécicos, 1 monotécico, insertados cerca de la fauce o en el tercio superior del hipanto, resultado el la mitad superior de las anteras exerta; anteras dorsifijas (el filamento se inserta en la mitad dorso-basal del conectivo, a veces cerca de la base y las anteras parecen basifijas), las ditécicas subcuadradas a anchamente elipsoides; filamento breve, glabro o hirsútulo; tecas oblongoides, rectas, o botuliformes, de dehiscencia longitudinal; conectivo angosto o algo ensanchado, no extendido por sobre las tecas, a veces ligeramente escotado en ápice y/o base, a veces con algunos tricomas uniseriados, cortos, en ápice y dorso; pistilodio emergente desde la base interior del hipanto, glanduliforme, subcupular, anchamente ovoide o subhemisférico. Inflorescencias carpeladas 1-floras (raro 2-3-floras), corta o largamente pediceladas, co-axilares con las estaminadas o en nudos diferentes; pedicelos desde glabrescentes hasta villósulos, hirsutos o hirsuto-villosos, a menudo algo ensanchados hacia el ápice. Flores carpeladas ebracteadas; hipanto cortamente cilíndrico, a menudo con indumento externo e interno como en las flores estaminadas; cáliz y corola similares a las de las flores estaminadas; estaminodios 3-5, insertados cerca de la fauce en posiciones intermedias, a menudo aproximados de a pares, quedando uno apartado (cuando son 5), claviformes, setiformes u ovado-dentiformes, redondeados en el ápice, rectos o algo incurvos, glabrescentes o hirsútulos; ovario ínfero, elipsoide a angostamente elipsoide, fusiforme u oblongo-elipsoide, con base usualmente redondeada, 2-placentífero, glabrescente, hirsuto o hirsuto-tomentoso, con tricomas eglandulares filiformes o cónicos con base unicelular, agudos, patentes o algo adpreso-ascendentes; óvulos numerosos, horizontales; estilo columnar, breve o bien desarrollado, glabro, con 2 ramas breves; nectario basal presente, periestilar, anular, craso y notable (tenue en flores jóvenes); estigmas oscura o notablemente 2lobulados, con lóbulos subesféricos u oblongoides y algo arqueados, fimbriado-lamelados, papilosos. Fruto elipsoide, ovoide o subgloboso, a veces cortamente apiculado, liso o ligeramente costado, glabro, híspido o densamente hirsuto-villoso, amarillento o rojizo cuando maduro. Semillas elipsoides, ovoides u ovado-elipsoides, emarginadas, comprimidas o no (y sólo ligeramente hacia el extremo hilar), superficie lisa o algunas veces con excrescencias esponjosas cuando húmedas; saco ariloide mucilaginoso.

Género sudamericano con 4 especies distribuidas desde el nordeste de Brasil hasta el norte de la Patagonia argentina. Usualmente habitan sistemas serranos, hasta los $1200 \mathrm{~m}$ s.m., creciendo en laderas expuestas, secas o en valles algo más húmedos; una de las especies ( $M$. sagittifolius) también se extiende por el litoral de los ríos Uruguay, de la Plata y del océano Atlántico, las sierras centrales de la Argentina y la precordillera de los Andes.

Etimología. El nombre genérico alude a la semejanza con las flores del género Melothria L. (del griego "anthos" = flor). 
Observación. Hasta esta tesis el género Melothrianthus contaba con una única especie ( $M$. smilacifolius); en esta tesis tres especies, antes ubicadas en Apodanthera, se transfieren a Melothrianthus, sobre la base de estudios morfológicos y moleculares (véanse Capítulos 2 y 3 ). En la filogenia combinada obtenida en esta tesis, Melothrianthus smilacifolius resultó agrupada con estas tres especies transferidas. Melothrianthus se aparta de Apodanthera, principalmente, por sus ovarios 2-placentíferos, interior del hipanto villoso-lanoso, presencia de pistilodio emergente en la base interior del hipanto de las flores estaminadas, zarcillos simples, presencia de nectario periestilar y semillas usualmente poco comprimidas (vs. ovarios (2-)3 o 5placentíferos, interior del hipanto glabro, ausencia de pistilodio, zarcillos 2-fidos, ausencia de nectario periestilar y semillas fuertemente comprimidas en Apodanthera).

\section{Clave de las especies de Melothrianthus}

1. Plantas glabrescentes; hojas angosta o anchamente hastadas u oblongo-lanceoladas, enteras, usualmente con dos aurículas subtriangulares notables en la base de la lámina, el margen ligeramente dentado, subcoriáceas a coriáceas, glabrescentes; ovario glabrescente; fruto ligeramente costado, glabrescente

M. smilacifolius

1'. Plantas pubescentes a hirsuto-villosas; hojas de contorno acorazonado, subtriangular o sagitado, enteras, lobadas o sectadas, el margen entero o tóscamente dentado, membranáceas; ovario hirsuto; fruto liso, piloso o hirsuto

2(1'). Hojas acorazonadas a ovado-acorazonadas; plantas completa y muy densamente hirsuto-villosas, con indumento argénteo; flores estaminadas bracteadas, con bráctea linearlanceolada en la base del pedicelo, persistente o caduca

M. argenteus

2'. Hojas ovado-triangulares o sagitadas, enteras, lobadas o sectadas; plantas hírtulas o hirsutas, con indumento blanquecino; flores estaminada ebracteadas (raramente con bráctea foliosa, reducida, en $M$. sagittifolius)

3(2'). Flores estaminadas urceolado-cilíndricas; pistilodio truncado en el ápice, sub 3-crestado; pétalos enteros; estigmas obscuramente 2-lobulados, con lóbulos suborbiculares. NE de Brasil

M. glaziovii

3'. Flores estaminadas subcilíndrico-infundibuliformes; pistilodio hemiesférico, ovoide o subcupular; pétalos apenas a notablemente lobulados; estigmas 2-lobulados, con lóbulos oblongoides. Extremo sur de Brasil (Rio Grande do Sul), Uruguay y nordeste y centro de la Argentina

M. sagittifolius 
1. Melothrianthus argenteus (Cogn.) Belgrano, comb. nov. Basónimo: Apodanthera argentea Cogn., Mém. Couronnes Autres Mém. Acad. Roy. Sci. Belgique 27: 42. 1877, "In Brasilia: a. St.-Louis (Os Organos), 11 octobre 1867 (Glaziou, no 1614, in hb. Bruxell.)." TIPO. Brasil. Rio de Janeiro. St. Louis (Os Org.), 11 Oct 1867, A. F. M. Glaziou 1614 (holotipo, BR-659 431!; isotipos, P-751825!, R). Figura 56.

Apodanthera argentea Cogn. var. angustifolia Cogn., Mém. Couronnes Autres Mém. Acad. Roy. Sci. Belgique 27: 42. 1877, "ß.- Rio de Janeiro, 1872 (Glaziou, n 4817, in hb. Eichler)." TIPO. Brasil. Rio de Janeiro, Itataia, 7 Jun 1871, A. Glaziou 4817 (lectotipo, P-751793!, aquí designado; isolectotipos, C, G, LE, R). Pro syn., Gomes Klein (1996: 103).

Apodanthera argentea Cogn. var. latifolia Cogn., Pflanzenr. 66(IV. 275 I): 59. 1916, "Provinz Minas Gerais, bei Caraça (Glaziou n. 14850b. - Herb. Berlin)". TIPO. Brasil. Minas Gerais. Caraçá, 13 Jun 1884, A. Glaziou 14850 (lectotipo, C!, aquí designado; isolectotipos, K!, P!). Pro syn., Gomes Klein (1996: 103).

Hierbas perennes, diclio-monoicas, zarcillosas, con indumento argénteo profuso. Tallos subcilíndricos, estriados longitudinalmente, de 1-3 mm de diámetro, herbáceos, ramificados, hirsuto-tomentosos, más profusamente en las partes jóvenes, con tricomas egladulares filiformes, agudos, argénteos, patentes o algo ascendentes; entrenudos de 3-16 cm de largo. Hojas enteras, pecioladas; pecíolos estriados, de 1,2-6 cm de largo, profusamente hirsutovillosos; láminas acorazonadas a ovado-acorazonadas, de 6-17 x 3,5-10 cm, ápice usualmente acuminado, excepcionalmente algo redondeado, margen remotamente denticulado (hidátodos), de consistencia membranácea, con indumento argénteo conformado por tricomas uniseriados, filiformes y cónicos de base unicelular, agudos y más o menos erectos, más profusos en la cara abaxial, principalmente sobre los nervios. Zarcillos simples, hirsutos. Inflorescencias estaminadas racemiformes, pedunculadas, 3-12-floras; pedúnculo estriado, hirsútulo, de 1,2$7,5 \mathrm{~cm}$ de largo; pedicelos filiformes, de $2-5 \mathrm{~mm}$ de largo, densamente hirsuto-villosos. Flores estaminadas bracteadas hacia la base del pedicelo; brácteas linear-lanceoladas, de 2-9 mm de largo, hirsuto-tomentosas, persistentes o caducas; hipanto subcilíndrico-infundibuliforme, levemente ensanchado hacia el ápice, de 5-10 mm de largo x 2-4,5 mm de ancho hacia el ápice, densamente hirsuto-villoso externamente, con tricomas eglandulares filiformes, con célula apical aguda, argénteos, patentes o algo escendentes, villoso a lanoso-villoso interiormente, en la mitad superior; sépalos angostamente lanceolados, de 4-8 x ca. $1 \mathrm{~mm}$, con indumento como el hipanto; pétalos angostamente elípticos, de 4-6,5 x 1,5-3 mm, ápice agudo, usualmente redondeado, amarillos, 5-nervios, corta y muy densamente afelpado-pilosos en la cara externa, con tricomas uniseriados, muy cortos, diminutamente pubérulos en la interna; estambres insertados en el tercio superior del hipanto, resultando el ápice de las anteras exerto; anteras dorsifijas, las ditécicas subcuadradas a anchamente elipsoides; filamento breve, 
insertado en la porción dorso-basal del conectivo; tecas botuliformes, rectas, de 1,8-3 mm de largo; conectivo algo ensanchado, lúteo, no extendido por sobre las tecas, a menudo ligeramente escotado en ápice y base, con algunos tricomas cortos en el ápice y el dorso; pistilodio con forma de muela oscuramente 3-crestada, de color castaño, ca. 1,2 mm de alto, emergiendo desde la base del hipanto. Inflorescencias carpeladas 1-floras, a veces co-axilares con las estaminadas; pedicelos de 1-3 cm de largo, hirsuto-villosos, más densamente hacia el ápice, donde suele estar algo ensanchado. Flores carpeladas ebracteadas; hipanto cortamente cilíndrico, de 4-9 x 2-4 mm, hirsuto-villoso exteriormente, uniforme y cortamente piloso interiormente; cáliz y corola similares a las de las flores estaminadas, las piezas apenas más angostas; estaminodios 5, insertados cerca de la fauce en posiciones intermedias, claviformes, redondeados en el ápice y algo incurvos, ca. 0,8 $\mathrm{mm}$ de largo, hirsútulos, aproximados de a pares, resultando uno de ellos apartado y desapareado; ovario angostamente elipsoide a subfusiforme, de 4-10 × 2-5 mm, 2-placentífero, densamente hirsuto-tomentoso, con tricomas filiformes, agudos, algo ascendentes y adpresos; óvulos numerosos, horizontales; estilo columnar, de 3-5 mm de largo, glabro, con 2 ramas muy breves; nectario basal, periestilar, anular, craso y notable, ca. 2,5 mm de diámetro; estigmas 2-lobulados, lóbulos oblongoides de 2-4,5 mm de largo, fimbriado-lamelados. Fruto anchamente elipsoide a subgloboso, de $2-3 \mathrm{x}$ 1,5-2,5 cm, densamente hirsuto-villoso, rojo cuando maduro. Semillas elipsoides, de 5-7 x 3,5-5 $\mathrm{mm}$, emarginadas, no comprimidas, sólo ligeramente hacia el extremo hilar, superficie lisa; saco ariloide mucilaginoso.

Distribución geográfica y hábitat. Especie endémica de Brasil, habita en regiones serranas de los estados de Minas Gerais, Rio de Janeiro y São Paulo, en el interior de bosques, hasta los 1000 m s.m. (Figura 58).

Etimología. El epíteto específico alude a la pubescencia argéntea de las plantas.

Fenología. La floración estaminada ocurre de junio a octubre, la carpelada de abril a septiembre, la fructificación de julio a septiembre (Gomes Klein, 1996).

Observación 1. El holotipo de Apodanthera argentea var. angustifolia (Glaziou 4817) en el herbario de Berlín se ha destruido (no existe fototipo de la serie Field Museum); se designa aquí como lectotipo a un duplicado del mismo (isotipo) depositado en el herbario P (con código de barras 751793), de acuerdo a lo estipulado en el CINB (Art. 9.9, 9.10).

Observación 2. El holotipo de A. argentea var. latifolia (Glaziou 14850b) en el herbario de Berlín no se ha localizado y no existe foto de la serie Field Museum. Gomes Klein (1996) indicó haber visto un duplicado en el herbario de Copenague $(C)$; sin embargo, no ha sido posible lo- 


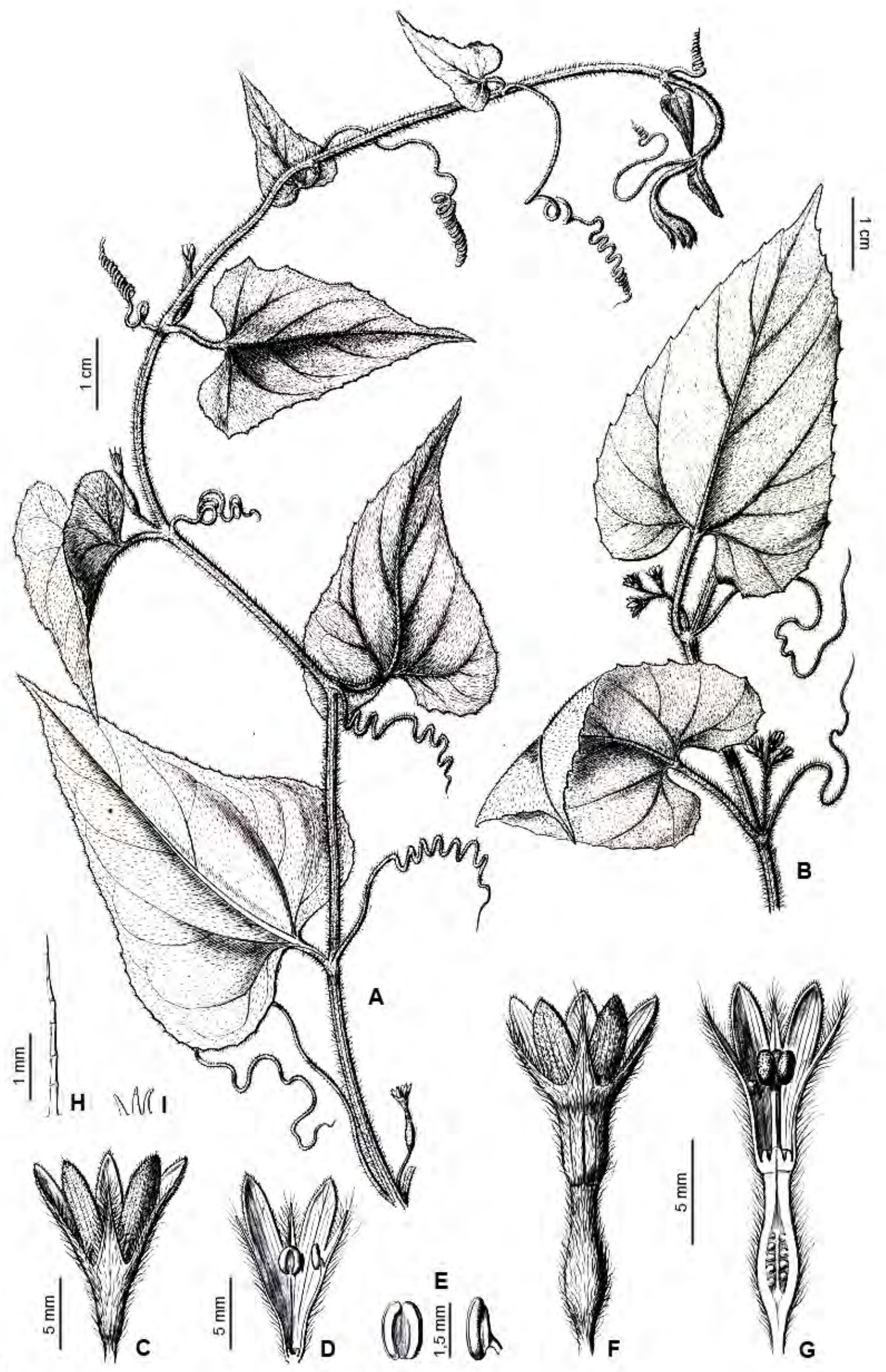

Figura 56. Melothrianthus argenteus. A. Tallo con flores carpeladas. B. Tallo con inflorescencias estaminadas. C. Flor estaminada, vista lateral. D. Flor estaminada, corte longitudinal. E. Estambres, vistas ventral y lateral. F. Flor carpelada, vista lateral. G. Flor carpelada, corte longitudinal. H. Tricoma del exterior del hipanto. I. Tricoma del exterior del pétalo. (Tomado de Cogniaux, 1878, con adaptaciones). 
calizar este ejemplar en dicho herbario, según comunicación de los Drs. Ryding y Friis, curadores de dicho herbario. Sí, en cambio, se ha localizado al ejemplar Glaziou 14850 de la misma procedencia, en los herbarios C, K y P. La letra "b" en la numeración tal vez se deba a una diferencia al preparar las etiquetas de los duplicados; en cualquier caso, en ausencia del tipo se designa aquí un lectotipo, eligiéndose el mencionado ejemplar en el herbario C (CINB Art. 9), el mismo se encuentra en perfecto estado de conservación y se ajusta al protólogo.

Observación 3. Melothrianthus argenteus se distingue fácilmente de las demás especies del género por sus hojas acorazondas, siempre enteras, y por el profuso indumento argénteo sobre toda la planta, conformado por tricomas eglandulares filiformes, agudos, patentes.

Material adicional examinado. BRASIL. Rio de Janeiro. Localidad no consignada, A. Glaziou 18253 (P). Mun. Petrópolis: Petrópolis, 26 Mar 1878, A. Glaziou 9466 (F, NY, P); S. Luiz, 11 May 1877, A. Glaziou 8714 (MO, P, US). Mun. Teresópolis: Teresópolis, 900 m s.m., 17 Sep 1929, A. C. Brade 9210 (CTES). São Paulo. Mun. São Paulo: São Paulo, nativa no Jardim Botânico, 4 Ago 1962, O. Handro 1025 (US).

2. Melothrianthus glaziovii (Cogn.) Belgrano, comb. nov. Basónimo: Apodanthera glaziovii Cogn., Pflanzenr. 66(IV. 275. I): 60. 1916, "Südbrasilinische Provinz: Prov. Bahia (Glaziou n. 20328)". TIPO. Brasil. Prov. de Bahia, "vulgo: Cabeza de negro", A. F. M. Glaziou 20328 (holotipo, BR-659 441!; isotipo, P-751817!). Figura 57.

Apodanthera glaziovii Cogn., Mém. Soc. Bot. France 3: 318. 1909, nom. nud.

Apodanthera lasiocalyx Cogn., Pflanzenr. 66(IV. 275. I): 58. 1916, "Südbrasilianische Provinz: Prov. Bahia, Catinga bei Caldeirão (E. Ule n. 7270. - Blühend im Oktober 1906. - Herb. Berlin)". TIPO. Brasil. Prov. Bahia. Catinga prope Calderão, fl. jaunes, Oct 1906, E. Ule 7270 (lectotipo, BR-659 424!, aquí designado; isolectotipos, HBG-506448!, L-602750!). Pro syn., Jeffrey (1992: 518, por error como A. eriocalyx Cogn.).

Hierbas perennes, diclino-monoicas, zarcillosas; raíces tuberosas, pivontates, engrosadas; tallos anuales cilíndricos, estriados, herbáceos y gráciles inicialmente, tornándose algo leñosos hacia la base con la edad y con corteza castaño-rojiza, hispídulos, con tricomas eglandulares cónicos de base unicelular, patentes, blanquecinos, agudos y de longitud variable; entrenudos de (1,3-)3-10 cm de largo. Hojas enteras, pecioladas; pecíolos estriados, de 0,4-4 cm de largo, híspidos, con tricomas patentes, blanquecinos; láminas de contorno ovado-triangular, de 3,2-13 x 1,2-10 cm, enteras o 3-7-pinnatilobadas (incluso en el mismo tallo), lóbulos cuando presentes subopuestos, rendondeados, base de la lámina cordada o subtruncada, ápice cortamente 
acuminado, margen usualmente sinuado, tenue a tosca e irregularmente dentado, remotamente denticulado (hidátodos), de consistencia membranácea o tenuemente membranácea, ligeramente discolores, de color verde oscuro, a menudo algo más pálido abaxialmente, fina y densamente tomentoso-pubescentes en ambas caras, algo más profusamente en la abaxial, con tricomas cónicos de base unicelular, adpresos; los nervios muy notables en la cara abaxal. Zarcillos simples, hispídulos. Inflorescencias estaminadas 4-20(- $\infty$ )floras, pedunculadas, racemiformes, con las flores a menudo congestas hacia el ápice del racimo (y la inflorescencia adquiere aspecto de umbela pedunculada); pedúnculo hirsútulo, de 0,6-7 cm de largo, gráciles, ca. $1 \mathrm{~mm}$ de diámetro; pedicelos filiformes, de 1-5 mm de largo, tomentosos a lanosos, persistentes, con el ápice algo ensanchado y recurvo, más claro que el raquis. Flores estaminadas ebracteadas; hipanto urceolado-cilíndrico, levemente ensanchado hacia el ápice, de 3,5-6 x 2,4-3,5 mm, verde amarillento, exteriormente hirsuto-tomentoso, con tricomas eglandulares filiformes, y cónicos de base unicelular y célula apical aguda o algo redondeada, interiormente villoso-lanoso cerca de la fauce, con tricomas eglandulares, con forma de "falange"; sépalos angostamente lanceolados, de 1,5-3,3 mm de largo x 1,5 mm de ancho en la base, con indumento externo como el hipanto; pétalos ovado-elípticos, de 3-5 x 2-3 $\mathrm{mm}$, cortamente apiculados o acuminados, de color amarillo pálido, con tintes verdosos en la cara externa, 5-nervios, afelpado-tomentosos en la cara externa, con tricomas cortos y profusos y otros ascendente-pilosos, más largos, agudos, principalmente sobre los nervios, la cara interna es glabrescente; estambres insertados en la fauce del hipanto, resultando su mitad superior exerta; anteras dorsifijas, las 2 ditécicas subrectangulares; filamento brevísimo, insertado en la mitad inferior del conectivo, glabro; tecas rectas o apenas arqueadas y botuliformes, de 1,8-3 mm de largo; conectivo ensanchado o no, lúteo, no extendido por sobre las tecas, a menudo algo escotado en ápice y base, hirsútulo dorsalmente y en el ápice; pistilodio glanduliforme, redondeado o aplanado en el ápice, ca. 0,5 mm de alto x $1 \mathrm{~mm}$ de ancho. Inflorescencias carpeladas 1-floras, subsésiles a pediceladas; pedicelos cortamente villosos, de 0,4-6 cm de largo. Flores carpeladas ebracteadas; hipanto cortamente cilíndrico, de 4-5 x 3-3,5 mm, hirsuto-tomentoso exteriormente, con tricomas eglandulares filiformes, algo ascendentes, villoso-lanoso en el interior, cerca de la fauce; sépalos linear-subulados, ca. 3,5 $\mathrm{mm}$ de largo $\times 1 \mathrm{~mm}$ de ancho en la base, hirsutos exteriormente; pétalos elíptico-lanceolados, ca. $4,5 \times 3 \mathrm{~mm}$, ápice agudo, color e indumento similar a los de las flores estaminadas; estaminodios 3-5, diminutos y muy difíciles de observar, insertados cerca de la fauce, entre los tricomas del interior del hipanto; ovario muy angostamente elipsoide a fusiforme, de 7-11 x 2-4 $\mathrm{mm}, 2$-placentífero, hirsuto-tomentoso, con tricomas eglandulares cónicos de base unicelular, agudos, algo ascendentes; óvulos numerosos, horizontales; estilo columnar, de 2-3 mm de largo, glabro, con 2 ramas breves, algo divergentes; nectario basal, periestilar, anular, craso, 1,5-2 mm de diámetro; estigmas obscuramente 2-lobulados, lóbulos subesféricos, de 1,5-2 mm de diámetro, papilosos. Fruto elipsoide, ca. 3-3,5 x 1,5-2 cm, cortamente apiculado, pilosos. 
Semillas (inmaduras) ovoides, algo comprimidas, ca. $4 \mathrm{~mm}$ de largo (semillas maduras no observadas).
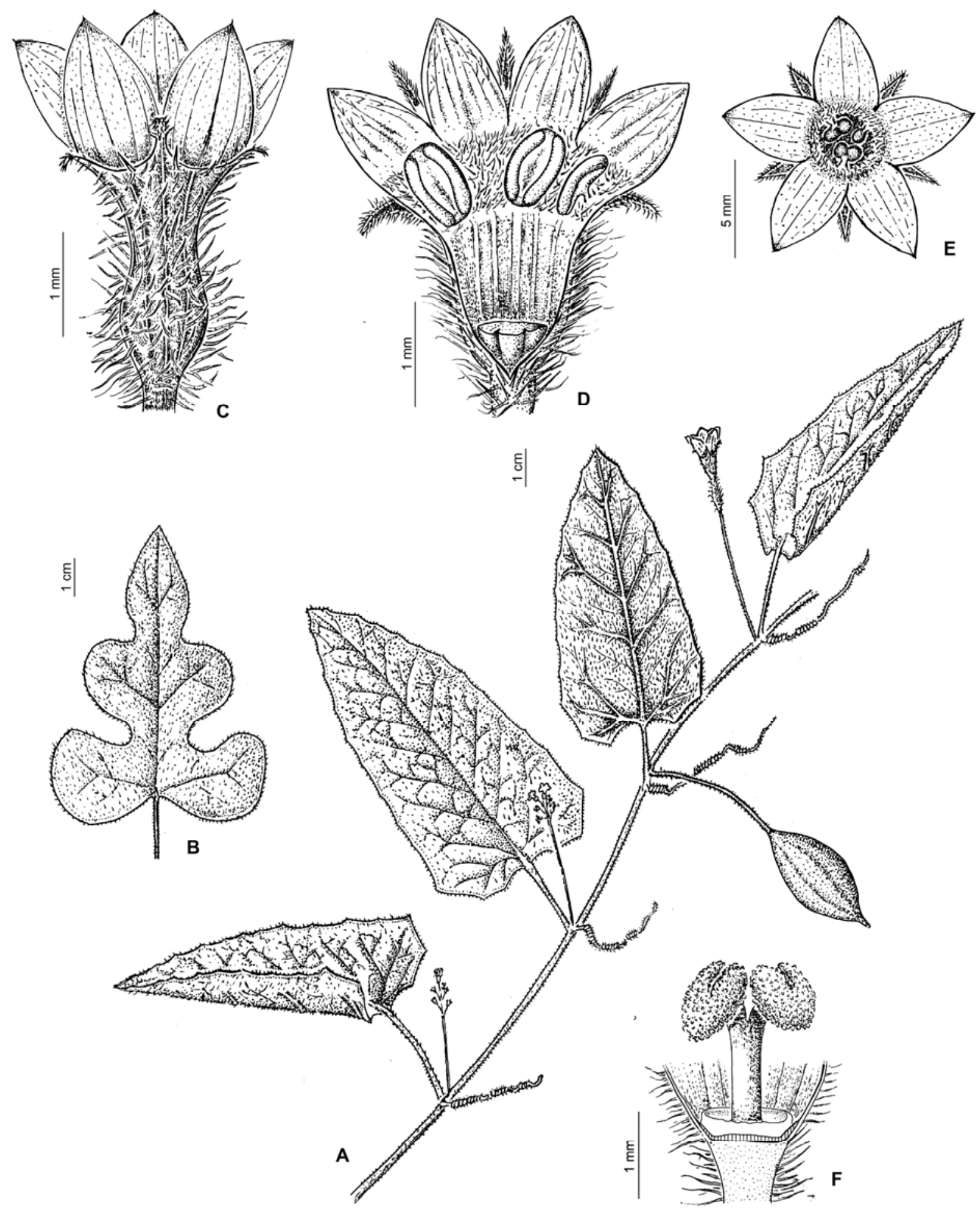

Figura 57. Melothrianthus glaziovii. A. Tallo con inflorescencias estaminadas y carpelada y fruto. B. Hoja lobada. C. Flor estaminada, vista lateral. D. Flor estaminada, hipanto desplegado y vista interna (uno de los pétalos ha sido seccionado). E. Flor estaminada, vista superior (en planta). F. Flor carpelada, corte longitudinal del hipanto, mostrando nectario periestilar, estilo y estigmas. (Dibujo de M. Schinocca). A, C-E de Harley 27129; B de Grupo Pedra do Cavallo 372; F de Moraes 2208. 
Distribución geográfica y hábitat. Habita en el nordeste de Brasil, en los estados de Paraíba, Pernambuco y Bahia (Figura 58), en regiones de Caatinga arbóreas, en laderas de cerros graníticos con grandes afloramientos rocosos y en los denominados "campos rupestres".

Fenología. Se ha coleccionado en flor y fruto en distintas épocas del año.

Observación 1. Si bien en el protólogo de A. glaziovii no se especifica el herbario en el cual está depositado el ejemplar tipo, se concluye que el holotipo está en el herbario del Jardín Botánico de Bruselas (BR) por cuanto A. Cogniaux trabajaba allí (ver CINM, recomendación 9.4A).

Observación 2. El tipo de Apodanthera lasiocalyx depositado en el herbario de Berlín (B) se ha destruido, de éste sólo se preserva una fotografía de la serie del Field Muesum, Neg. № F8956!. Por lo tanto, se propone como lectotipo el duplicado depositado en el herbario del Jardín Botánico de Bruselas (BR), según lo estipulado en el CINM (Arts. 9.9 y 9.10). Este isotipo, si bien está compuesto de fragmentos de hojas y flores, está acompañado de valiosas anotaciones y análisis florales de A. Cogniaux, autor del nombre, y es suficiente para caracterizar al taxón.

Observación 3. Melothrianthus glaziovii es similar a $M$. sagittifolius; se las puede distinguir, principalmente, por la forma del hipanto de la flor estaminada (urceolado-cilíndrico en la primera vs. subcilíndrico-infundibuliforme en la segunda), por el contorno de los pétalos (enteros vs. lobulados) y por la base de la lámina foliar (cordada o subtruncada vs. sagitada).

Material adicional examinado. BRASIL. Bahia. Mun. Boquira: arredores de Boquira, 19 Ene 1997, G. Hatschbach et al. 65978 (K). Mun. Cachoeira: Barragem de Bananeiras, vale dos rios Paraguacú e Jacuípe, 12³2'S, 395’W, 40-120 m s.m., Jul 1980, Grupo Pedra do Cavalo 372 (CEPEC, K). Mun. Cansanção: $14 \mathrm{~km}$ SW of Cansanção, on road to Queimadas, 47ºS, 39³4'W, 300 m s.m., 22 Feb 1974, R. M. Harley 16477 (CEPEC, K, NY, P). Mun. Macaúbas: Macaúbas, estrada para Canatiba, subida da Serra Poção, 600-800 m s.m., 20 Abr 1996, G. Hatschbach et al. 65111 (CTES, K). Mun. Maracás: Rod. BA 026, 13 a 15 km ao SW de Maracás, 26 Abr 1978, S. A. Mori et al. 9971 (NY, K). Mun. Pombal: Ribeira do Pombal, 1050'S, 38³2'W, 15 Ago 2003, M. L. Guedes et al. 10491 (CEPEC). Mun. Rio de Contas: 7 km da cidade na estrada para Livramento do Brumado, 13038'S, 41950'W, 650 m s.m., 12 Dic 1988, R. M. Harley et al. 27129 (CEPEC, K, NY). Ca. 6,5 km da cidade, na estrada que liga Rio de Contas à Livramento de Nossa Senhora, 1336'24'S, 4148'33'W, 880 m s.m., 29 Nov 2003, A. M. Amorim \& M. J. Belgrano 3889 (CEPEC). Mun. Santana: riacho de Santana, ca. 35,9 km E de Bom Jesus da Lapa na estrada para Caetité, 1327'44"S, 438'15"W, 460 m s.m., 
12 Feb 2000, L. P. de Queiroz 5920 (CEPEC). Mun. Serra Preta: 6 km W do Ponto de Serra Preta, Fazenda Santa Clara, 12²10'S, 39²0’W, 17 Jul 1985, L. Noblick \& Lemos 4218 (CEPEC, K). Paraíba. En regiones sêcas do Estado de Paraíba, 20 Abr 1959, J. Coêlho de Moraes 2084a (CTES). Mun. Areia: Areia, 2 Ago 1959, J. Coêllo de Moraes 2208 (US). Pernambuco. Serra da Russa, km 60, 19 Ene 1994, A. M. Miranda 1246 (CEPEC). Russinha, 4 Mar 1933, B. Pickel 3240 (US). Mun. Fazenda Nova: Fazenda Araras, 13 Ago 1998, W. M. Andrade \& L. S. Figueiredo 93 (K). Mun. Gravatá: entre Gravatá y Rusinha, 3 Feb 1981, A. Krapovickas et al. 38025 (CTES). Mun. Venturosa: Parque Estadual Pedra Furada, 8³4'30"S 3652'45’'W, 783 m s.m., 4 Ago 1998, K. C. Costa et al. 86 (K).

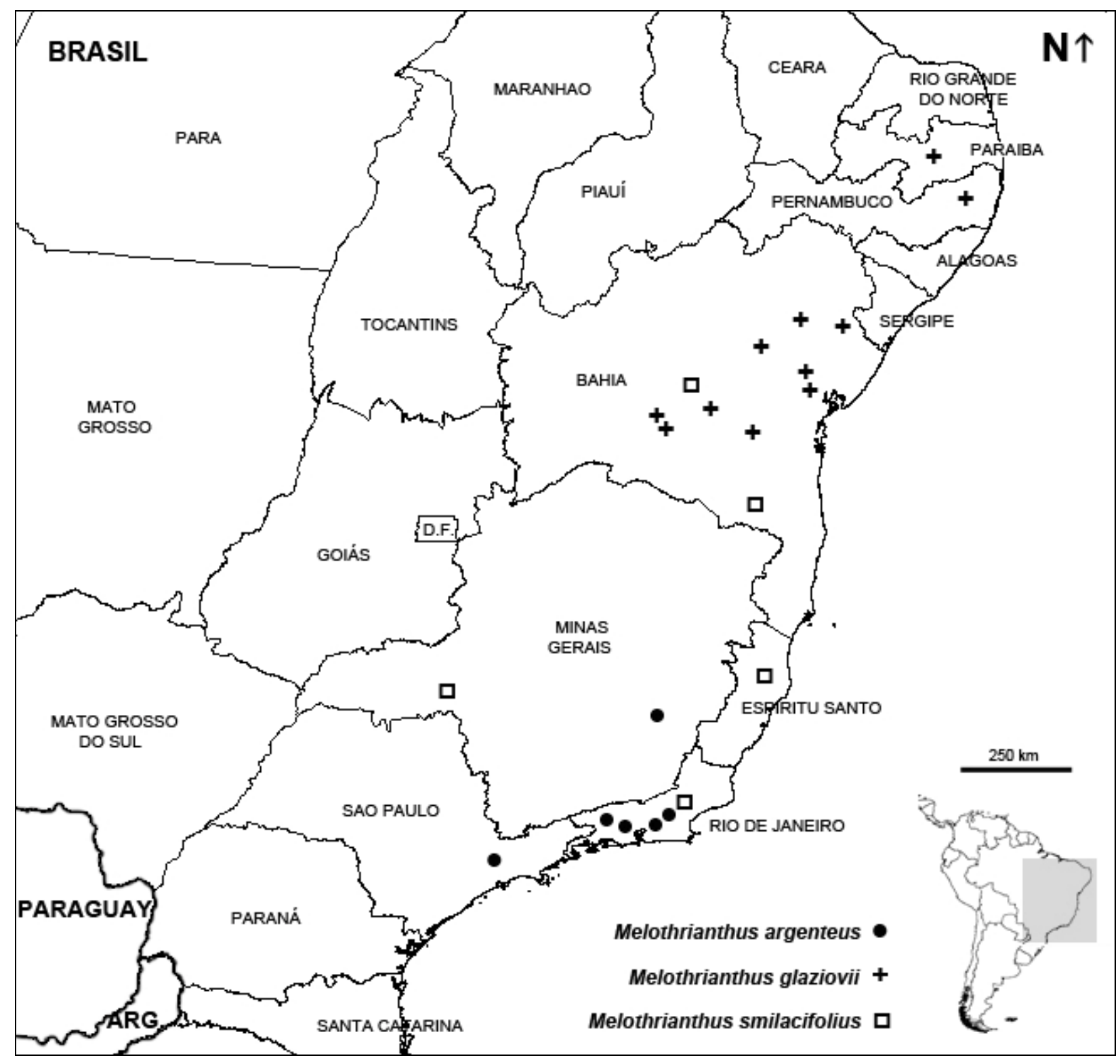

Figura 58. Mapa de distribución de Melothrianthus argenteus, M. glaziovii y M. smilacifolius. 
3. Melothrianthus sagittifolius (Griseb.) Belgrano, comb. nov. Basónimo: Wilbrandia sagittifolia Griseb., Abh. König. Ges. Wiss. Göttingen 19 [PI. Lorentz.]: 97. 1874. Apodanthera sagittifolia (Griseb.) Mart.Crov., Notul. Syst. (Paris) 15: 45. 1954. "Cordoba, pr. Las Peñas". TIPO. Argentina. Córdoba, bei Las Peñas, Feb 1871, P. G. Lorentz 173 (holotipo, GOET-2336!, isotipos, BR-649 268!, CORD-6292!). Figuras 59 y 62.

Wilbrandia linearis Cogn., FI. Bras. 6(4): 34. 1878. Apodanthera linearis (Cogn.) Mart.Crov., Notul. Syst. (Paris) 15: 46. 1954. "Habitat in Brasilia meridionali: Sello n. 3586". TIPO. Brasil, Sello 3586 (holotipo, BR-659 464!). Syn. nov.

Wilbrandia villosa Cogn., FI. Bras. 6(4): 34. 1878. Wilbrandia safittifolia Griseb. var. villosa (Cogn.) Mart.Crov., Bol. Soc. Argent. Bot. 4: 316. 1946. Apodanthera sagittifolia (Griseb.) Mart.Crov. var. villosa (Cogn.) Mart.Crov., Notul. Syst. (Paris) 15: 45. 1954. "Habitat in Brasilia meridionali: Sello n.d, 327; ad Montevideo: Sello, Gibert n. 411". TIPO. Uruguay. Montevideo, Sello s.n. (lectotipo, BR-649 297!, designado por R. Martínez Crovetto, Notul. Syst. (Paris) 15: 45. 1954; isolectotipo, K, con numeración "527"). Syn. nov.

Wilbrandia villosa Cogn. var. dissecta Cogn., Pflanzenr. 66(IV. 275. I): 74. 1916. Wilbrandia sagittifolia Griseb. var. dissecta (Cogn.) Mart.Crov., Bol. Soc. Argent. Bot. 1: 317. 1946. Apodanthera sagittifolia (Cogn.) Mart.Crov. var. dissecta (Cogn.) Mart.Crov., Notul. Syst. (Paris) 15: 45. 1954. "Argentina: bei Cordoba (Lorentz, Hieronymus, Galander. - Herb. Hieronymus); bei La Plata (Albert Lefebvre)". TIPO. Argentina. Buenos Aires, La Plata, 1891, A. Lefebre s.n. (lectotipo, BR-649 269!, designado por R. Martínez Crovetto, Notul. Syst. (Paris) 15: 45. 1954; isolectotipo, BA-28811!). Syn. nov.

Hierbas perennes, diclino-monoicas, zarcillosas; raíces tuberosas, pivotantes, se tornan subesféricas con la edad de las plantas, con unas pocas raicillas laterales no tuberosas; tallo perenne único, subterráneo y tuberoso, breve (ca. $10 \mathrm{~cm}$ de largo x ca. 1,5 de diámetro), del que emergen uno o varios tallos anuales herbáceos, hasta de 3-4 m de largo, surcados, esparcida a densamente híspidos o hirsutos, más profusamente hacia los extremos jóvenes, con tricomas eglandulares filiflormes o cónicos, agudos, patentes, blanquecinos; entrenudos de 1,8-10(-14) cm de largo. Hojas enteras, pecioladas; pecíolos estriados, hasta de 6,5 cm de largo, escasa a densamente hirsutos; láminas subtriangulares, enteras o sectadas (incluso en el mismo tallo) o sagitadas, de 2-8,3(-13) x 1,2-4,5(-10) cm, con lóbulos basales lanceolados, algunas veces tan largos como el lóbulo distal, hasta de $4(-7) \mathrm{cm}$ de largo, margen subentero, ligeramente sinuado o dentado, membranáceas, ligeramente discolores, verdes en la cara adaxial, más pálido y ceniciento en la abaxial, con indumento de tricomas cónicos de base unicelular, adpresos, a menudo esparcidos en la cara adaxial, más profusos en la abaxial, a veces la cara adaxial es densamente escabroso-hirsuta por la presencia de tricomas cónicos, robustos, de base pluricelular, algo curvados y subadpresos, muy notables. Zarcillos simples, 
ralamente hirsutos. Inflorescencias estaminadas racemiformes, laxas, pedunculadas, 5-50floras; pedúnculo escasa a densamente hirsuto, de 3-22 cm de largo; pedicelos filiformes, densamente hirsutos, de 2-10 mm de largo, persistentes. Flores estaminadas ebracteadas o raramente con una bráctea foliosa reducida hacia la base del pedicelo; hipanto subcilíndricoinfundibuliforme, más ancho en el ápice, de 2-12 x 1,5-5 mm, la base redondeada, de color verde, exteriormente híspido o hirsuto, con tricomas filiformes, agudos, patentes, interiormente villoso-lanoso cerca de la fauce y en la mitad superior, con tricomas eglandulares filiformes entrelazados; sépalos subtriangulares a angostamente lanceolados, de 1,2-2,5 mm de largo $x$ ca. $1 \mathrm{~mm}$ de ancho en la base, esparcidamente hirsutos a hirsutos; pétalos ovados u obovadoelípticos, de 2-9 x 1,2-5 mm, amarillos, induplicados, con 2 lóbulos suborbiculares apenas o muy notables, villoso-hirsútulos en la cara externa, con tricomas cortos, agudos, muy abundantes, profusamente punteado-glandulares en la cara interna, con tricomas moruliformes; estambres 3, insertados en la fauce del hipanto, resultado su mitad superior exerta; anteras 2 ditécicas, la restante monotécica, dorsifijas, el filamento se inserta en la mitad basal del conectivo; filamento muy breve, con algunos tricomas cortos; tecas oblongoides, rectas o apenas arquedas y botuliformes, de 1,5-5 mm de largo; conectivo angosto, no extendido por sobre las tecas, glabro; pistilodio hemiesférico o cortamente oblongoide, lúteo, de 0,7-2 mm de alto x 0,8-1,5 mm de diámetro en la base. Inflorescencias carpeladas 1-floras, subsésiles a pediceladas, algunas veces co-axilares con las estaminadas; pedicelos hirsutos, de $2-5 \mathrm{~cm}$ de largo. Flores carpeladas ebracteadas; hipanto subcilíndrico, de 2-7 x 1,3-3,5 mm, algo más ancho y redondeado en la base, de color verde pálido, hirsuto exteriormente, densamente villoso-lanoso en la fauce; cáliz y corola similares a las de las flores estaminadas; estaminodios 5, subalternipétalos, a veces aproximados de a pares, quedando uno desapareado, diminutos, ca. $0,5 \mathrm{~mm}$ de largo, insertados cerca de la fauce del hipanto, entre los tricomas, muy difíciles de observar, dentiformes, con ápice obtuso y redondeado; ovario oblongo-fusiforme a elipsoide, algo redondeado en la base, enangostándose hacia el ápice, de 5-8 x 1,5-4 mm, 2-placentífero, verde intenso, densamente hirsuto, con tricomas eglandulares, agudos, blanquecinos patentes o algo ascendentes; óvulos numerosos, horizontales; nectario periestilar, anular, craso, de 1,5$2 \mathrm{~mm}$ de diámetro; estilo columnar, delgado, de 1,8-4 mm de largo, glabro, con 2 ramas breves pero bien diferenciadas y algo divergentes; estigmas profundamente 2-lobulado, lóbulos oblongoides, fimbriado-papilosos. Fruto elipsoide de 1,5-4 x 1,5-2,5 cm, redondeado en la base, a menudo algo apiculado cuando inmaduro, de color verde, con algunas líneas longitudinales verde oscuro, tornándose amarillentos al madurar, liso, esparcidamente hirsuto, más profusamente hacia el ápice, con tricomas blanquecinos, erecto-ascendentes. Semillas numerosas (ca. 20), ovoides u oblongo-ovoides, comprimidas, de 8,5-10 x 4,5-6,5 mm x 1-1,5 $\mathrm{mm}$ de grosor, levemente marginadas sagitalmente, de color castaño, más claro en el margen, tegumento con excrescencias esponjosas cuando húmedo; saco ariloide mucilaginoso. 


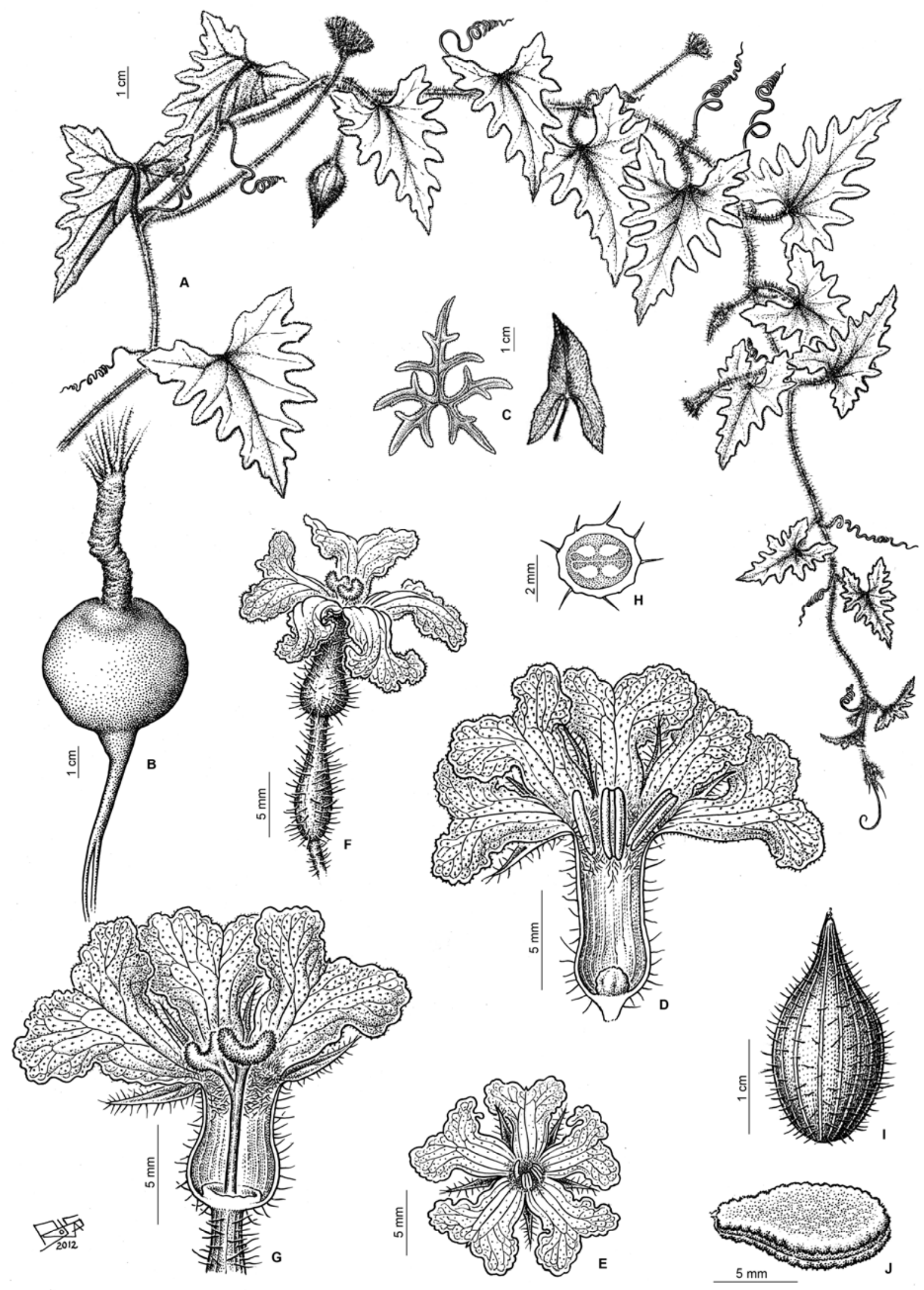

Figura 59. Melothrianthus sagittifolius. A. Tallo con inflorescencias estaminadas y carpeladas y fruto. B. Raíz tuberosa. C. Variación foliar: hoja sectada y hoja sagitada. D. Flor estaminada, corte longitudinal. E. Flor estaminada, vista superior (en planta). F. Flor carpelada, vista lateral. G. Flor carpelada, corte longitudinal del hipanto y vista interna. H. Ovario, corte transversal. I. Fruto. J. Semilla. (Dibujo de V. Dudas y F. Rojas, Instituto Darwinion). Todo de Pozner \& Belgrano 257, excepto la hoja sagitada en C, tomado de Cogniaux, 1878. 
Distribución geográfica y hábitat. Se trata de la especie que alcanza el límite más austral de la familia Cucurbitaceae en Sudamérica. Se extiende desde el centro y sur de la provincia de Misiones (Argentina), hasta el sur de la provincia de Buenos Aires, en Carmen de Patagones; hacia el oeste habita en las provincias del centro de la Argentina, alcanzando la provincia de La Rioja, en la precordillera de los Andes. También está presente en el extremo sur de Brasil (estado de Rio Grande do Sul) y en Uruguay (Figura 60). En su amplio rango de distribución la especie ocupa ambientes diversos, principalmente sistemas serranos semiáridos, entre los 300 y 2800 m s.m. (serranía central de Misiones, sierras bonaerenses de Tandil y Ventana, Sierra de Comechingones en Córdoba y San Luis, precordillera de La Rioja y San Juan); también habita en zonas arenosas cercanas a la costa marina o en las riberas de los grandes ríos de la cuenca Paraná-Platense.

Nombres vulgares. "Sandía de la India", "sandía del Diablo" (Martínez Crovetto, 1946).

Etimología. El epíteto específico alude al contorno sagitado de las hojas.

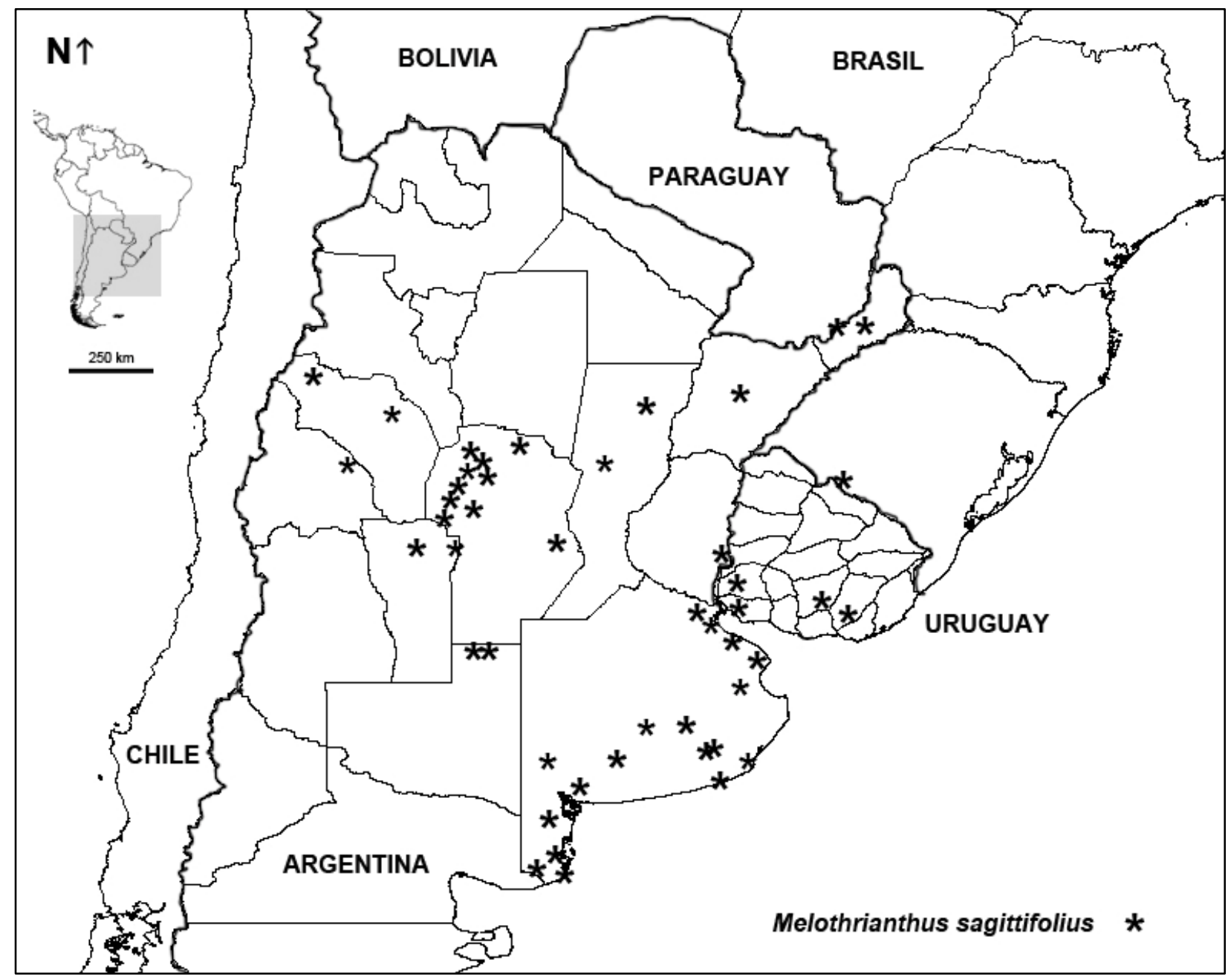

Figura 60. Distribución geográfica de Melothrianthus sagittifolius. 
Fenología. Hallada en flor y fruto durante los meses más cálidos, entre octubre y abril.

Observación 1. Se trata de una especie extremadamente variable en cuanto al contorno y grado de división de la lámina foliar, tamaño de las flores y densidad del indumento, lo que ha conducido a la descripción de diversos taxones en el rango específico y varietal. En efecto, la lámina foliar varía desde subtriangular a notablemente hastada, entera a profundamente pinnatisecta; las flores estaminadas desde 2-3 mm de largo, en uno de los extremos del rango de variación, hasta 11-12 $\mathrm{mm}$ en el otro; el indumento de estructuras vegetativas y reproductivas varía desde esparcido a densamente híspido o villoso. Sin embargo, el estudio de gran cantidad de muestras de herbario y de algunas poblaciones naturales, ha evidenciado un gradiente continuo de variación de los caracteres antes enunciados; los ejemplares tipo de los binomios involucrados (ver la sinonimia propuesta) sólo representan los extremos de la variación intraespecífica. Adicionalemente, dicha variación no posee una correspondencia geográfica evidente, de modo que resulta áun más difícil establecer límites precisos entre estos taxones. Por estos motivos, se ha preferido aceptar la existencia de una única especie, muy variable, y relegar las variedades a su sinonimia.

Observación 2. Los ejemplares provenientes de la provincia de Misiones (Argentina) muestran los mayores tamaños relativos de hojas, flores, entrenudos y diámetro de tallos; asimismo, son los especímenes que poseen el indumento más ralo y esparcido, con láminas tenuemente membranácea. Probablemente se trate de una forma ecológica debida a la mayor humedad relativa y menor exposición solar; futuros estudios poblacionales permitirían corroborarlo.

Observación 3. Entre los especímenes estudiados, Gallinal PE-5513 (F) posee flores carpeladas con 3 ramas estilares, algo excepcional.

Observación 4. En el protólogo de Wilbrandia linearis no se especifica el herbario en el cual está depositado el ejemplar tipo, sin embargo, se indica que el holotipo está en el herbario del Jardín Botánico de Bruselas (BR) por cuanto A. Cogniaux trabajaba allí (ver CINM, recomendación 9.4A), el ejemplar cuenta además con sus anotaciones.

Observación 5. En la descripción original de Wilbrandia sagittifolia, Grisebach dice, por error, "fasciculi carpelada 3-7 flori" (en vez de "flores solitarias"); este error fue advertido por Martínez Crovetto (1954b).

Observación 6. Hasta el momento, el único material brasileño de esta especie fue citado por Paiva Lima (2010) para la localidad de Santana do Livramento (PACA-57188), en el extremo 
sur del estado de Rio Grande do Sul, cerca de la frontera con Uruguay. Dicho material no fue examinado para el presente trabajo pero se incluye en el mapa de distribución de la especie.

Material adicional examinado. ARGENTINA. Buenos Aires. Pdo. Bahía Blanca: Bahía Blanca, sobre la Ruta Nac. 3 a Buenos Aires, 55 km de Bahía Blanca, 18 Ene 1944, A. T. Hunziker 4379 (NY). Pdo. Balcarce: Balcarce, Sierra Larga, Feb 1942, R. Martínez Crovetto 2393 (MO2389261, SI). Balcarce, Cinco Cerros, Abr 1925, A. Castellanos s.n. (BA-25/1432). Pdo. Berazategui: Pereyra, terraplén del ferrocarril, 14 Mar 1932, A. L. Cabrera 2060 (US). Pdo. Castelli: Canal 15-Cerro de La Gloria, 10 Ene 1938, L. R. Miccio Peralta 473 (SI). Pdo. General Alvarado: Miramar, en los médanos, 23-27 Feb 1930, A. L. Cabrera 1 (NY). Miramar, 12 Mar 1928, R. L. Parodi s.n. (BA-28/474). Camino a Miramar, cerca del arroyo El Durazno, 25 Ene 1929, C. m. Hicken 550 (SI). Pdo. General Pueyrredón: Cantera "La Copelina", entre cerros, 29 Feb 1932, C. M. Hicken 558 (SI). Sierra de los Padres, 19 Feb 1970, A. E. Lanfranchi 1722 (SI). Pdo. La Plata: Elizalde, 22 Feb 1943, Mogilner 24 (SI). Pdo. Olavarría: Olvarría, cantera de la Providencia, 4 Abr 1899, C. M. Hicken s.n. (SI-25312). Pdo. Patagones: Isla del Jabalí, Rincón del Banco, 24 Dic 1981, T. M. Pedersen 13202 (NY, UC). Bahía San Blás, 1,5 km al N del pueblo, 19 Feb 1988, J. H. Hunziker 11539 (SI). Entre San Blás y Bahía Blanca, Oct-Nov 1903, C. Ameghino s.n. (BA-28815, BA-68476). Carmen de Patagones, Feb-Mar 1932, Daguerre s.n. (BA-6666). Río Negro inferior, Feb 1912, L. Hauman s.n. (BA-28813). Prope Carmen de Patagones, Feb 1912, L. Hauman s.n. (SI-25359). Pdo. Pilar: Zelaya, 8 Feb 1925, Pereyra s.n. (BA-257270). Zelaya, F.C.C.A., 23 Dic 1934, A. Burkart 6672, 6674 (SI). Pdo. Punta Indio: Monte Veloz, 29 Ene 1929, R. A. Pérez Moreau s.n. (BA-8396). Pipinas, Mar 1923, L. Hauman s.n. (BA-28812). Pdo. Saavedra: Pigüé, Cerro de la Cruz, 10 Abr 1900, C. M. Hicken s.n. (SI25358). Pdo. Tandil: Estancia Azucena, F.C.S., 178 m s.m., 5 Feb 1946, J. Meninci 69 (LIL). Tandil, 200 m s.m., 18 Dic 1948, B. Sparre 5291 (LIL). Tandil, en el Cerro Leones, 2 Mar 1946, A. Krapovickas 2959 (LIL, SI). N foothill of Cerro San Luis, $5 \mathrm{~km}$ on ruta prov. 74 towards the east from crossing with ruta nac. 226, ca. 200 m s.m., 28 Feb 1996, B. Leuerberger \& S. C. Arroyo 4508 (SI). Pdo. Tornquist: Sierra de la Ventana, quebrada del Arroyo San Bernardo, 400-550 m s.m., 14 Mar 1979, Proyecto Ventania 679 (NY). Sierra de la Ventana, 2 Abr 1920, A. Castellanos s.n. (BA-25/1746). Sierra de la Ventana, El Carol, 4 Mar 1940, Kuhnemann 299 (BA-36021). Sierra de la Ventana, La Paleta, 9 Mar 1940, Kuhnemann 385 (BA-36020). Córdoba. Sin localidad consignada, Ene 1908, M. Lillo 7886 (LIL). Dpto. Calamuchtita: Sierra Grande (falda E), Río Reartes, 1300 m s.m., 12 Dic 1946, A. T. Hunziker 7234 (SI). Dpto. Capital: prope Córdoba, 4 Nov 1876, G. Hieronymus s.n. (sintipo de Wilbrandia villosa var. dissecta, BR-649 300!). Dpto. Ischilín: Ongamira, 24 Oct 1971, T. M. Pedersen 9963 (CTES). Dpto. Marcos Juárez: Leones, 1 Dic 1965, W. Partridge s.n. (BA-60315); 28 Dic 1965, W. Partridge s.n. (BA-59885). Dpto. Pocho: camino a Pocho, 6,5 km al NW del acceso desde Ruta

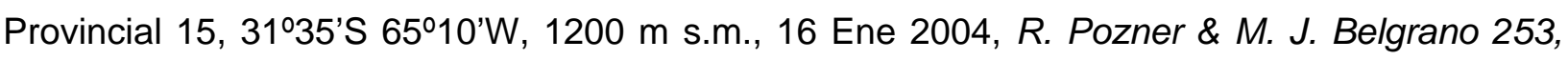


254, 257 (SI). Ca. Taninga, 1100 m s.m., 4 Feb 1951, J. H. Hunziker 2765 (LIL). Dpto. Punilla: Los Cocos, Ene 1916, L. Hauman s.n. (BA). Uritorco, 26 Ene 1922, A. Castellanos s.n. (BA28816, LIL-36234). Capilla del Monte, 28 Oct 1918, A. Castellanos 705 (SI). Dpto. Río Seco: Estancia San Faustino, al este de la Ruta Prov. 10, Laguna de la Sal, M. Sayago 225 (SI). Dpto. San Alberto: La Cocha, 10 Mar 1921, A. Castellanos s.n. (LIL-36232). Corrientes. Dpto. Mercedes: Yopré, costa del Arroyo Payure, 25 Mar 1945, T. Ibarrola 2761 (LIL). Distrito Federal. cerca del bañado de San José de Flores, C. Spegazzini s.n. (SI). Entre Ríos. Dpto. Uruguay: Concepción del Uruguay, 40 km al N de Gualeguaychú, 19 Abr 1965, A. Burkart et al. s.n. (K, SI-25793, UC). La Pampa. Dpto. Rancul: Alpataca, 5 Feb 1944, J. Fortuna s.n. (SI106500). Dpto. Realicó: Realicó, 9 Ene 1945, A. G. Schulz s.n. (LIL-116284). La Rioja. Dpto. Capital: La Rioja, dique, 2 Mar 1941, A. Burkart 12587 (SI). Dpto. General La Madrid: entre Jagüé y Salina del Leoncito, a $23 \mathrm{~km}$ del cruce con el camino a Chile, paraje llamado Agua de Cándido, 2750 m s.m., 5 Feb 1999, F. Biurrun et al. 5490 (CTES, SI). Misiones. Dpto. Cainguás: Campo Cumprido (hoy Campo Grande), 22 Sep 1945, M. S. Bertoni 2100 (LIL). Dpto. San Ignacio: Santo Pipó, 19 Feb 1948, "flor amarilla, fruto piriforme, trepadora de $2 \mathrm{~m}$ de longitud", A. G. Schulz 7172 (CTES, LIL). San Juan. Dpto. Valle Fértil: de Sierra de Chávez a Sierra de Elizonfo, 1600-2000 m s.m., 28 Ene 1987, R. Kiesling \& S. Meglioli 6649 (SI). San Luis. Sin localidad consignada, Ene-Feb 1934, Pastore s.n. (BA-14892). Dpto. no consignado: Región del Solosta, Ene 1934, M. A. Vignati 183 (NY). Dpto. Ayacucho: San Francisco, 11 Feb 1925, A. Castellanos s.n. (BA-25/1003). Dpto. Chacabuco: 4 km al S de Papagayos, $950 \mathrm{~m}$ s.m., 13 Dic 1989, C. Ezcurra \& M. Ponce 523 (SI). Santa Fe. Dpto. San Cristóbal: al oeste de Huanqueros, 1 Abr 1984, D’Angelo 809 (SI). Dpto. Vera: Vera, 15 Dic 1982, Pire 1187 (SI). URUGUAY. Colonia. Estancia Cerros de San Juan, 21 Ene 1977, T. M. Pedersen s.n. (CTES). Florida. Estación Dr. Alejandro Gallinal, Campo Experimental de pastos, Estancia Rincón de Santa Elena, Feb 1947, B. Rosengurtt 5869 (BR, F, LIL). Lavalleja: Cerro Verdún, cultivada en Kew Gardens, sin fecha, E. N. Yellow 353-69.03047 (K). Minas, Penitente, 17 Mar 1924, C. Osten 17030 (BA-1005). Montevideo. Montevideo, in campis, 1866, E. Gibert 411 (sintipo de Wilbrandia villosa, BR-649 302!, K-430955!, K-430956!). Soriano. Juan Jackson, Santa Elena, 8 Dic 1942, A. Gallinal et al. PE-5513 (F).

4. Melothrianthus smilacifolius (Cogn.) Mart.Crov., Notul. Syst. (Paris) 15: 60. 1954. Basónimo: Apodanthera smilacifolia Cogn., Mém. Couronnes Autres Mém. Acad. Roy. Sci. Belgique 27: 42. 1877. "In Brasilia: in fruticetis humidiusculis prope Mand et Serra late (Riedel, in herb. Acad. Petrop.); in prov. Minas Geraes (A. de Saint-Hilaire, $B^{1}$, n. 736, in hb. Mus. Paris); in eadem prov. In locis umbrosis, secus rivos ad Ponte-Alta (A. de SaintHilaire, $B^{1}$, n. 851, in hb. Mus. Paris)." TIPO. Brasil. Minas Gerais, 1816-1821, A. de Saint- 
Hilaire $B^{1} 851$ (lectotipo, P-257363!, designado por R. Martínez Crovetto, Notul. Syst. 15: 60. 1954). Figura 61.

Apodanthera smilacifolia Cogn. var. angustifolia Cogn., Pflanzenr. 66(IV. 275. I): 60. 1916, "Prov. Minas Gerais, bei Ouro Preto (Schwacke n. 9387); Prov. Rio de Janeiro, Petropolis (Glaziou n. 17009):". TIPO. Brasil. Rio de Janeiro. Nova Friburgo, 30 Jul 1887, A. Glaziou 17009 (lectotipo, P-257357!, designado por R. Martínez Crovetto, Notul. Syst. 15: 60. 1954; isolectotipo, K-435977!). Pro syn., Martínez Crovetto (1954c: 60).

Hiebras perennes, diclino-monoicas, zarcillosas; tallos anuales cilíndricos, estriados longitudinalmente, herbáceos a subleñosos, glabrescentes, a veces esparcidamente pubérulos; entrenudos de 2,5-11 cm de largo. Hojas enteras, pecioladas; pecíolos estriados, de 1-4 cm de largo, hispídulos; láminas lanceoladas, oblongas u oblongo-lanceoladas, de 2-22 x 1,5-8,5 cm, de base subcordada, hastada o brevemente sagitada, con extensiones basales subtriangulares, de 0,2-3,5 cm de largo, apiculadas y con margen esparcidamente denticulado y algo revoluto, de consistencia usualmente cartácea, glabrescentes en ambas caras. Zarcillos simples, glabrescentes. Inflorescencias estaminadas racemiformes, congestas, subsésiles o pedunculadas, 5-35-floras; pedúnculo estriado, de 0,1-8 cm de largo, glabrescente a ralamente hispídulo; pedicelos filiformes, de 0,5-22 $\mathrm{mm}$ de largo, persistentes, glabrescentes o muy esparcidamente hispídulos, más abundantemente hacia el ápice, con tricomas eglandulares simples, con célula apical aguda, ascendentes. Flores estaminadas bracteadas; brácteas angostamente ovado-lanceoladas, de 1-4 mm de largo, escariosas, pajizas, persistentes; hipanto angostamente campanulado, redondeado en la base, de 2-5 x 2-4,5 mm, glabrescente o pubérulo-pubescente externamente, con mezcla de tricomas eglandulares simples, agudos, ascendentes y tricomas glandulares, sésiles, internamente el hipanto es densamente villosolanoso, en su porción media superior; sépalos lanceolados a triangulares, de 1-4 x 0,8-1 mm, pubérulos externamente, principalmente hacia el ápice, glabros internamente; pétalos oblongolanceolados, de 4-6 x 1,5-3 mm, de ápice redondeado, induplicado en el pimpollo, 5-nervios, amarillo lavado o muy pálido, con pubescencia densa, corta y afelpada en la cara externa, abundantemente papiloso-glandular en la interna, con tricomas glandulares moruliformes; estambres insertados cerca de la fauce del hipanto, subsésiles; anteras libres, a veces algo conniventes, dorsifijas, el filamento se inserta muy cerca de la base del conectivo (pareciendo basifijas); tecas ovado-oblongoides, rectas a apenas curvadas, de 1-2,5 mm de largo; conectivo no extendido por sobre las tecas, a menudo escotado en el ápice y con abundantes tricomas eglandulares simples y cortos en el ápice y en el dorso; pistilodio sub-cupular, glanduliforme, de 0,5-1,2 mm de diámetro, emergente desde la base del hipanto. Inflorescencias carpeladas 1floras (más raramente 2-3-floras); pedicelos estriados, glabrescentes, de 4-18 mm de largo. Flores carpeladas ebracteadas; hipanto subcilíndrico, de 6-8 x 2-3 mm, algo más ancho en 
base y ápice, pubérulo exteriormente, villoso interiormente, cerca de la fauce; cáliz y corola similares a las de las flores estaminadas; estaminodios 3, ovados, pequeños; ovario angostamente elipsoide o oblongoide, de 5-9 x 2-3 mm, 2-placentífero, glabrescente; óvulos numerosos, horizontales; nectario periestilar, anular; estilo columnar, de 2-3 mm de largo, con 2 ramas muy breves; estigmas 2-lobulados, lóbulos lamelado-frimbriados, de 1-2 mm de largo. Fruto elipsoide, de 2-3 x 0,7-1,2 cm, oscuramente costado, glabrescente. Semillas ovadooblongoides, de 2,5-3 mm de largo, emarginadas, no comprimidas, sólo ligeramente hacia el extremo hilar, superficie lisa.

Distribución geográfica y hábitat. Endémica de Brasil, en el Distrito Federal y en los estados de Bahia, Minas Gerais, Espírito Santo, Paraná, Rio de Janeiro, Rio Grande do Sul, Santa Catarina y São Paulo. Habita en la denominada "Floresta atlántica" que se extiende desde el estado de Espiritu Santo hasta el de Rio Grande do Sul, y en remanentes de bosques, en sitios húmedos, en los estados de Bahia, Goias y en el Distrito Federal, a elevaciones superiores a los 800 m s.m. (Gomes Klein 1996; Paiva Lima 2010, Porto 1974). Figura 58.

Nombres vulgares y usos. "Azougue dos pobres", azougue vegetal", "cipó azougue", "cipó santo", "catingueira", "chá de boubas", "cota", "falso azougue”, "mercúrio vegetal", "raíz de cota", "remedio de gallico" (Gomes Klein, 1996). En Brasil, la infusión de sus hojas y tallos se utiliza en forma de baños para combatir enfermedades cutáneas (forúnculos, sarna, herpes, etc.); la infusión de sus raíces como antirreumático (Gomes Klein, 1996).

Etimología. Seguramente por tener sus hojas similitud con las de algunas especies del género Smilax L. (Smilacaceae), las "zarzaparrillas".

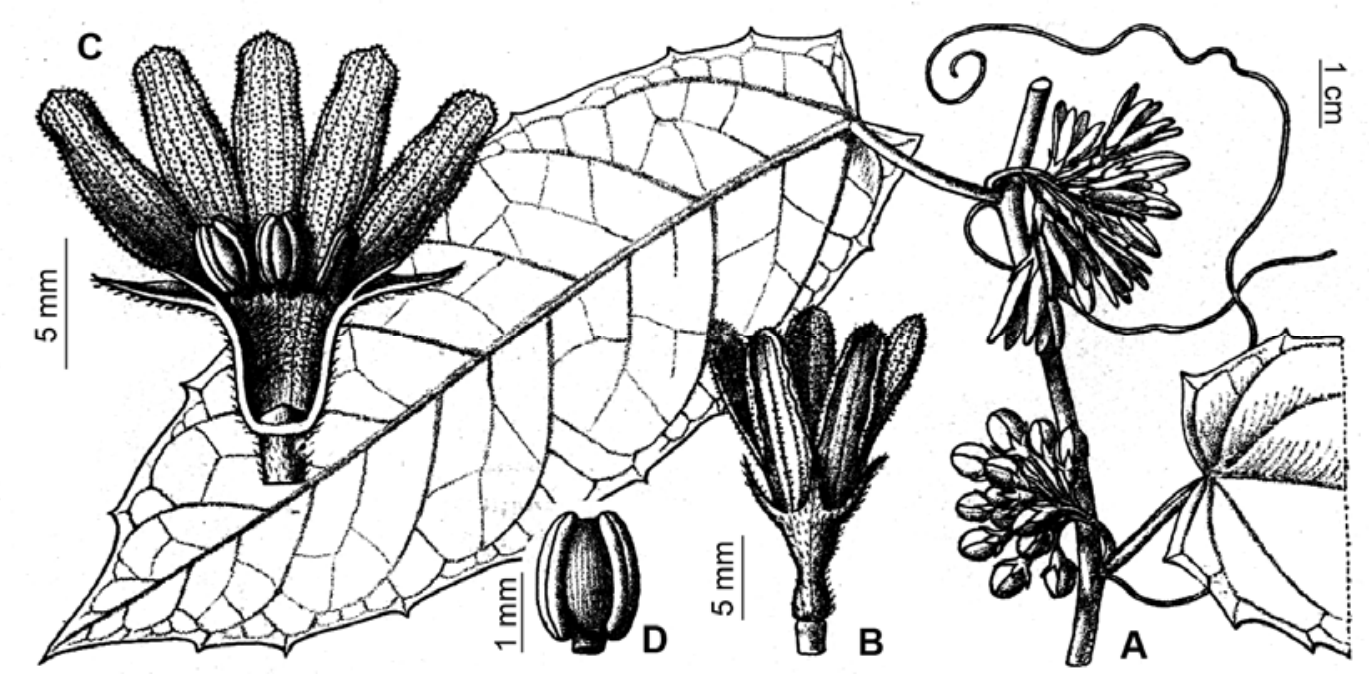

Figura 61. Melothrianthus smilacifolius. A. Tallo con inflorescencias estaminadas. B. Flor estaminada, vista lateral. E. Flor estaminada, corte longitudinal. D. Estambre. (Tomado de Cogniaux, 1916). 
Fenología. Florece de abril a mayo y fructifica de abril a noviembre.

Observación. Esta especie se distingue fácilmente de las demás especies del género por las plantas glabrescentes, por el contorno y consistencia de la lámina foliar (oblongo u oblongolanceolado y cartáceas vs. acorazonado, ovado-triangular o sagitado y membranáceas), las inflorescencias estaminadas a menudo cortamente pedunculadas (vs. largamente pedunculadas) y los frutos glabros y ligeramente costados (vs. pilosos y lisos).

Material adicional examinado. BRASIL. Bahia. Mun. Palmeiras: Pai Inácio. Fenda no Morro do Pai Inácio, leste do Cruzeiro, 12²8'S, 41²8'16”W, 1130 m s.m., 24 Abr 1995, E. Melo et al. 1785 (CEPEC). Mun. Ribeirão do Largo: ca. 23 km na estrada, Itambé/Encruzilhada, 15019'39"S, 4045'5"W, 870 m s.m., 14 Ago 2001, A. M. Carvalho et al. 6914 (CEPEC). Espirito Santo. Mun. Linhares: Rod. BR-101, 16 Jun 1985, G. Hatschbach \& J. M. Silva 49483 (CEPEC). 

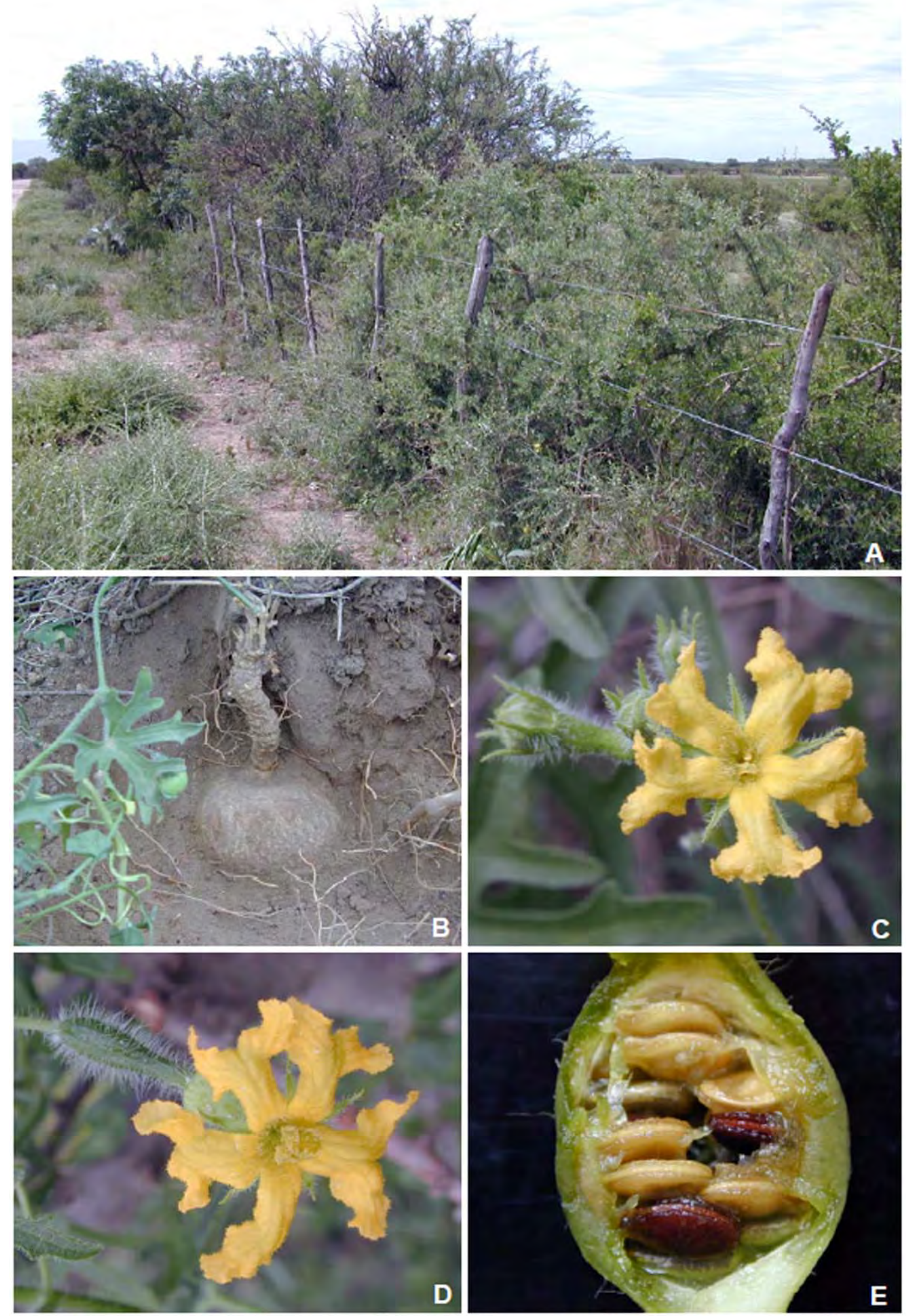

Figura 62. Melothrianthus. Melothrianthus sagittifolius. A. Hábitat: cercanias de Pocho (Córdoba, Argentina). B. Porción superior de la raiz y tallo perenne subterráneo. C. Flores estaminadas. D. Flor carpelada. E. Fruto, corte longitudinal, semillas dispuestas horizontalmente. (Fotos M. J. Belgrano, de Pozner \& Belgrano 253, SI). 
Pseudoapodanthera (Cogn.) Belgrano comb. et stat. nov. Basónimo: Apodanthera Arn. Sect. Pseudoapodanthera Cogn., Pflanzenr. 66(IV. 275. I): 66. 1916. ESPECIE TIPO. Pseudoapodanthera fasciculata (Cogn.) Belgrano (= Apodanthera fasciculata Cogn.), lectotipo aquí designado.

Subarbustos, diclino-monoicos, zarcillosos; raíces tuberosas, robustas, con la porción apical expuesta sobre la superficie (la tuberización afecta también a la porción basal del tallo); tallos subcilíndricos, estriados longitudinalmente, inicialmente herbáceos, algo carnosos, glabrescentes o puberulentos (con tricomas cónicos de base unicelular, algo adpre-sos y dispersos) con la edad se tornan leñosos hacia la base, lenticelados. Hojas pecioladas, profundamente 3-5-lobadas o pedatisectas, las de los nudos fértiles fácilmente caducas; pecíolos estriados, pubescentes; láminas de contorno ampliamente ovado o subpentagonal, base cordada, algo discolores, verde en la cara adaxial y blanquecino o ceniciento-tomentoso en la abaxial, con indumento profuso de tricomas eglandulares de base unicelular, erectos o apenas arquedos en la cara adaxial, mucho más abundantes y notablemente adpresos en la abaxial, algunas veces la cara adaxial con tricomas cónicos d base multicelular, persistente, que confiere escabrosidad a la superficie; lóbulos de contorno elíptico o lanceolado u oblongoobovado, los basales (los más laterales) menores y a veces 2-lobulados, de borde entero o dentado, remotamente denticulado (hidátodos), ápice agudo a obtuso o rendondeado, mucronulado. Zarcillos simples, robustos, se tornan leñosos, caedizos, con base persistente, cónica. Inflorescencia estaminada fasciculiforme o con aspecto de racimo congesto, sésil o pedunculado, con eje algo engrosado. Flores estaminadas numerosas en cada inflorescencia, ebracteadas, pediceladas, amarillas (hipanto, cáliz y corola); hipanto subcilíndrico-infundibuliforme, exteriormente glabro, piloso o villoso, interiormente villoso a media altura, por debajo de los estambres; sépalos 5, de vernación abierta, estrechamente laceolados o linear-lanceolados, recurvos, con indumento similar al del hipanto; petalos 5, alternisépalos, de vernación planoinduplicada (bordes y ápice apenas plegados), lanceolados o ensiformes, ápice agudo a obtuso, con 3-5 nervios más o menos paralelos entre sí, inicialmente rectos y conniventes hacia el centro de la flor, luego algo reflexos, diminutamente puberulentos en ambas caras o sólo notablemente en la ventral, a veces la cara ventral puede ser cortamente villosa; estambres 3 , 2 ditécicos y 1 monotécico, insertados en el tercio superior del hipanto o cerca de la fauce, alternipétalos; anteras dorsifijas, oblongo-elipsoides; filamento brevísimo, glabro; anteras botuliformes, rectas o ligeramente arqueadas, amarillo brillante; conectivo angosto, no expandido en el ápice, glabro. Inflorescencia carpelada fasciculiforme o muy cortamente espiciforme, pauci o pluriflora. Flores carpeladas subsésiles, amarillas (hipanto, cáliz y corola); hipanto subcilíndrico-infundibuliforme o tubular, exteriormente glabro, piloso o villoso, interiormente villoso a media altura del tubo; cáliz y corola similares a los de las flores estaminadas; estaminodios 3, anteriformes o mameliformes, subiguales (a veces 2 de ellos obscuramente 2- 
lobulados); ovario ínfero, ovoide, base usualmente redondeada, apice atenuado, glabrescente, 2-placentífero; óvulos 8-12 (4-6 por lóculo), horizontales; estilo columnar, glabro, con 2 ramas; estigmas 2-fidos o 2-lobulados, con segmentos oblongoides, papilosos. Fruto ovoide a ovadooblongoide, indehiscente, carnoso, base redondeada, ápice atenuado y cortamente apiculadorostrado, inicialmente verdoso o castaño verdoso, rojo cuando maduro. Semillas piriformes, poco comprimidas, lisas, castañas, con el borde sagital blanco-cremoso, emarginadas, excepto hacia el extremo hilar que es más notorio en relieve; saco ariloide hialino.

Género endémico del nordeste de Brasil con cuatro especies de los estados de Bahia y Minas Gerais; habita en zonas semiáridas de la Caatinga y en los denominados "campos rupestres", entre los 900 y 1600 m s.m.

Observación 1. En la reconstrucción filogenética obtenida en esta tesis Pseudoapodanthera resultó monofilético, apoyado por la sinapomorfía "hipanto de color amarillo". Sus cuatro especies son muy similares entre sí y sus límites deben ser confirmados mediante el estudio de un mayor número de especímenes y poblaciones naturales. Pseudoapodanthera es muy similar a Doyerea (ambos géneros son hermanos en la filogenia) en cuanto al hábito, tipo de xilopodio parcialmente expuesto sobre la superficie, tipo de inflorescencia fasciculiforme o cortamente espiciforme; se los puede distinguir, en cambio, por la prefloración del cáliz (abierta en Pseudoapodanthera y valvar en Doyerea), el color del hipanto y cáliz (amarillo vs. ocráceo) y el hipanto de las flores estaminadas (subcilíndrico-infundibuliforme vs. acampanado) y carpeladas (subcilíndrico o tubular vs. muy breve, casi anular).

Observación 2. Cogniaux (1916), al fundar Apodanthera sección Pseudoapodanthera, incluyó dentro de ésta a tres especies: $A$. trifoliata y $A$. congestiflora, consideradas sinónimos y transferidas en esta tesis al género Doyerea; la restante, $A$. fasciculata es designada aquí como especie lectotipo del nuevo género Pseudoapodanthera (CINB Art. 10.2).

Clave de las especies de Pseudoapodanthera

1. Hojas pedatisectas (5-folioladas); inflorescencias estaminadas con aspecto de racimos congestos, pedunculados, con eje algo engrosado (a veces los entrenudos del extremo del tallo son muy breves y el conjunto de racimos da aspecto de panícula); pétalos villosos ventralmente

P. pedisecta

1'. Hojas profundamente 3-5-lobadas; inflorescencias estaminadas fasciculiformes o con aspecto de racimos congestos, sésiles, con eje muy breve y engrosado; pétalos glabrescentes en ambas caras o incospicuamente pilósulos 
2(1'). Hipanto y sépalos de las flores estaminadas y carpeladas glabros; hipanto de la flor carpelada tubular, de 5,5-9 $\mathrm{mm}$ de largo

P. fasciculata

2'. Hipanto y sépalos de las flores estaminadas y carpeladas pilosos o villosos (rala o densamente), con tricomas eglandulares filiformes, agudos, rígidos, blanquecinos, algo ascendentes; hipanto de la flor carpelada cilíndrico-infundibuliforme, hasta de $4 \mathrm{~mm}$ de largo

3(2'). Hipanto y sépalos de las flores estaminadas y carpeladas pilosos o ralamente villosos; inflorescencias estaminadas y carpeladas a menudo co-axilares; inflorescencia carpelada pauciflora (1-5-flora)

P. hindii

3'. Hipanto y sépalos de las flores estaminadas y carpeladas densamente villosos; inflorescencias estaminadas y carpeladas en nudos distintos; inflorescencia carpelada pluriflora (7-30-floras)

P. villosa

1. Pseudoapodanthera fasciculata (Cogn.) Belgrano, comb. nov. Basónimo: Apodanthera fasciculata Cogn., Pflanzenr. 66(IV. 275. I): 67. 1916. "Südbrasilinische Provinz: Bahia, in der Gebüschregion bei Maracás) E. Ule 7005. - Blühend un fruchtend im September 1906. - Herb. Berlin)". TIPO. Brasil. Bahia, Schlingpflanze in der Gebüschregion bei Maracás, Sep 1906, E. Ule 7005 (lectotipo, HBG-506449!, aquí designado; isolectotipo, BR-659 458!). Figura 63.

Subarbustos, diclino-monoicos, zarcillosos; tallos anuales se tornan subleñosos con la edad y glabrescentes; entrenudos hasta de $10 \mathrm{~cm}$ de largo. Hojas pecioladas; pecíolos robustos, estriados, glabros; láminas caducas, desconocidas. Zarcillos simples, robustos, se tornan subleñosos, caedizos, con la porción basal peresistente. Inflorescencia estaminada fasciculiforme, con eje brevísimo, grueso, carnoso y densamente blanco-villoso. Flores estaminadas numerosas en cada inflorescencia, ebracteadas, amarillas; pedicelos filiformes, de 2-5 mm de largo, glabros, persistentes, articulados en el ápice; hipanto cilíndricoinfundibuliforme, de 5,5-8 x 2,5-3 mm, redondeado en la base, exteriormente glabro, villosolanoso en el interior, a media altura del tubo, por debajo de los estambres, con tricomas eglandulares filiiformes, con célula apical aguda; sépalos angostamente triangular-lanceolados, de 1,7-2,5 mm de largo, glabros, algo reflexos; petalos ensiformes, de 3-4,5 x 0,8-1,3 mm, ápice usualmente agudo, algo redondeado, diminuta y obscuramente pilósulos en ambas caras o glabrescentes, con 5 nervios más o menos paralelos entre sí; estambres insertados en el tercio superior del hipanto, resultando exerto sólo el ápice; filamento brevísimo, glabro; anteras 
botuliformes, rectas o ligeramente arqueadas, de 2,8-3 mm de largo; conectivo angosto, glabro, no extendido en el ápice. Inflorescencia carpelada similar en estructura e indumento a la estaminada. Flores carpeladas numerosas, cortamente pediceladas a subsésiles, amarillas; pedicelos breves, hasta de $1,5 \mathrm{~mm}$ de largo, con algunos tricomas eglandulares, agudos, patente-ascendentes; hipanto tubular, de 5,5-9 x 1,2-1,6 mm, exteriormente glabro, villosolanoso en el interior, a media altura del tubo, con tricomas eglandulares filiformes, entrelazados; sépalos angostamente triangulares a subulados, de 1-2,2 mm de largo, reflexos, glabros; pétalos similares a los de las flores estaminadas, de 2,5-2,7 x 0,85-1 mm; estaminodios 3, subtriangular-dentiformes, ápice redondeado, desiguales (dos de ellos algo mayores, probablemente vestigios de las anteras ditécicas), insertados a media altura del hipanto, en la porción villoso-lanosa del mismo; ovario angostamente elipsoide, de 4-7 x 2-2,5 $\mathrm{mm}$, base redondeada, apice truncado, glabro, lustroso, 2-placentífero; estilo columnar, delgado, 6-8,5 mm de largo, glabro, con 2 ramas breves; estigmas ligeramente 2-fidos, de superficie papilosa. Fruto ovado-oblongoide, de 8-10 $\mathrm{mm}$ de largo, cortamente apiculado y rostrado. Semillas desconocidas.

Distribución geográfica y hábitat. Endémica del estado de Bahia (Brasil), hasta el momento sólo conocida para la localidad tipo (Figura 65).

Fenología. Coleccionado en flor y fruto durante el mes de septiembre.

Etimología. El epíteto específico alude al tipo de inflorescencia de aspecto fasciculado.

Observación 1. El tipo de Apodanthera fasciculata depositado en el Herbario de Berlín (B) fue destruido durante la Segunda Guerra Mundial. Por este motivo, se procedió a designar un lectotipo (CINB, Arts. 9.2, 9.9, 9.10). El ejemplar elegido es un duplicado del tipo depositado en el herbario HBG (con código de barras 506449), este isotipo es el más completo de entre los dos localizados y está compuesto de una rama con flores estaminadas y de otra con flores carpeladas y estaminadas co-axilares. Adicionalmente, se localizó otro duplicado en el herbario del Jardín Botánico de Bruselas (BR), y que cuenta con valiosas anotaciones y análisis florales de A. Cogniaux, autor del binomio; sin embargo, este ejemplar sólo consta de fragmentos insuficientes que no permiten caracterizar correctamente a la especie. El lectotipo carece de hojas, al igual que el tipo destruido en $\mathrm{B}$, según lo demuestran la descripción original de la especie y una foto del tipo de la Serie del Field Museum Neg. N8954.

Observación 2. Pseudoapodanthera fasciculata (bajo Apodanthera) fue colocada por Paiva Lima (2010: 75) en sinonimia de $P$. pedisecta (bajo Apodanthera); sin embargo, este criterio no se comparte en esta tesis. En $P$. fasciculata la inflorescencia estaminada es fasciculiforme y el 
hipanto de la flor carpelada tubular, hasta de $9 \mathrm{~mm}$ de largo; en $P$. pedisecta la inflorescencia estaminada es racemiforme, cortamente pedunculada y el hipanto de la flor carpelada es subcilíndrico-infundibuliforme, más breve, ca. $2 \mathrm{~mm}$ de largo.
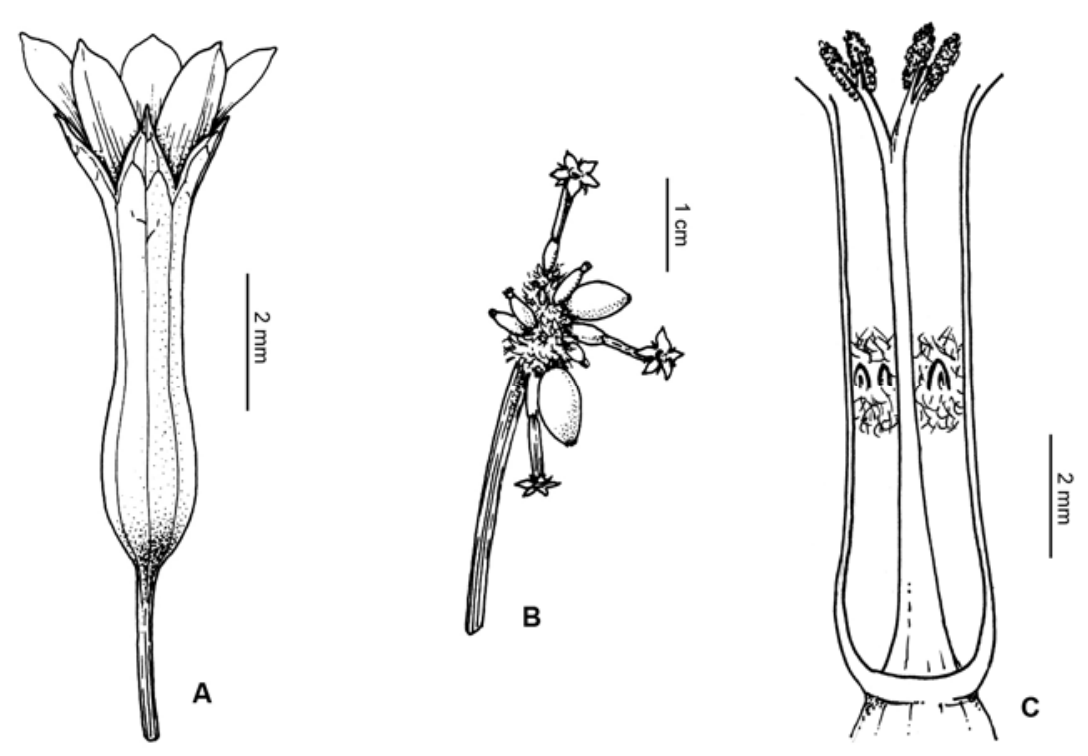

Figura 63. Pseudoapodanthera fasciculata. A. Flor estaminada, vista lateral. B. Porción de un tallo con flores carpeladas y frutos. C. Flor carpelada, corte longitudinal del hipanto. A y B tomados de Jeffrey, 1992; C dibujo M. J. Belgrano, de Ule 7005.

2. Pseudoapodanthera hindii (C. Jeffrey) Belgrano, comb. nov. Basónimo: Apodanthera hindii C. Jeffrey, Kew Bull. 47: 519. 1992, "Brazil, Bahia, Pico das Almas, Harley et al. 26688 (holotypus CEPEC!, isotypi, K!, SPF)". TIPO. Brasil. Bahia. Mun. Rio de Contas, Pico das Almas, vertente leste, campo e mata ao NW do Campo do Queiroz, $13^{\circ} 31^{\prime} \mathrm{S}$, 41ํ 58' W, 1500-1550 m, 29 Nov 1988, R. M. Harley, R. de Mello-Silva, I. Cordeiro \& L. Rossi 26688 (holotipo, CEPEC-45825!; isotipos, F-2129550!, K-430966!, K-430967!, MBM!). Figura 64.

Subarbustos, diclino-monoicos, zarcillosos; raíces tuberosas, con la porción apical expuesta sobre la superficie; tallos suculentos, se tornan subleñosos hacia la base, glabrescentes, verdes a glaucos hacia la porción basal, anaranjados hacia el extremo superior, a menudo el extremo distal del tallo se desprende y cae al madurar los frutos (conjuntamente con hojas y zarcillos); entrenudos de 4,5-13 cm de largo, ligeramente dispuestos en zig-zag, a veces muy reducidos y breves en el extremo de las ramas. Hojas pecioladas, caducas; pecíolos robustos, estriados, glabrescentes, de 1,8-10 cm de largo; láminas de contorno anchamente ovado o subpentagonal, de $2-7 \times 3-8 \mathrm{~cm}$, profundamente $3(-5)$-lobadas, base amplia y profundamente 
cordada, cara adaxial verde, con tricomas erectos o apenas arquedos, cara abaxial verde ceniciento, tomentosa, con abundantes tricomas agudos, adpresos y muy entrelazados; lóbulos lanceolados, oblanceolados u oblongos, de ápice subagudo a obtuso o redondeado, el margen usualmente sinuoso, a menudo dentado hacia el ápice, remotamente denticulado (hidátodos), el lóbulo central entero, de 1,7-5 x 0,7-2,5 cm, los laterales 2-lobulados, de 1,8-4,5 x 1,2-3 cm, senos entre los lóbulos redondeados, a veces muy amplios. Zarcillos simples, robustos, se tornan leñosos, articulados y caedizos, con la base persistente, cónica. Inflorescencia estaminada fasciculiforme o brevemente racemiforme y con eje breve, hasta de $12 \mathrm{~mm}$ de largo, grueso, carnoso y densamente blanco-villoso. Flores estaminadas numerosas en cada inflorescencia, ebracteadas; pedicelos filiformes, hasta de $5 \mathrm{~mm}$ de largo, villosos, persistentes, articulados en el ápice; hipanto cilíndrico-infundibuliforme, de 5,5-8 x 2,5-3 mm, redondeado en la base, amarillo brillante al madurar la flor, exteriormente piloso a ralamente villoso, con tricomas eglandulares uniseriados, con célula apical aguda, erecto-ascendentes, en el interior villoso-lanoso, a modo de banda lanosa a media altura del tubo, por debajo de los estambres, con tricomas eglandulares filiformes, agudos, entrelazados; sépalos angostamente triangularlanceolados, ca. $1,5 \mathrm{~mm}$ de largo, con indumento como el hipanto, algo reflexos; pétalos ensiformes, ca. $2 \mathrm{~mm}$ de largo, ápice usualmente agudo, algo redondeado, diminuta y esparcidamente pilósulos en ambas caras, con 5 nervios más o menos paralelos entre sí; estambres insertados en el tercio superior del hipanto; filamento brevísimo, glabro; anteras botuliformes, rectas o ligeramente arqueadas, de 2,5-3 mm de largo; conectivo angosto, glabro, no expandido en el ápice. Inflorescencia carpelada similar en estructura e indumento a la estaminada, a menudo co-axilares con éstas, paucifloras, 1-5-floras. Flores carpeladas cortamente pediceladas a subsésiles, amarillas; pedicelos muy cortos (en el fruto alcanzan hasta $3 \mathrm{~mm}$ de largo), villosos, con tricomas eglandulares uniseriados, agudos, patenteascendentes; hipanto subcilíndrico, de 3-3,5 x 1,7-2 mm, exteriormente villoso-ascendente como el pedicelo, interiormente lanoso como en la flor estaminada; sépalos angostamente lanceolados, de 1-2,5 mm de largo, con indumento como el pedicelo e hipanto; pétalos ensiformes, de 2,5-3 x 0,7-1 mm, densa, corta y oscuramente pilósulos en ambas caras, con 5 nervios más notables, paralelos entre sí; estaminodios 3, anteriformes, ca. 0,75 mm de largo, desiguales (2 ditécicos, opositipétalos, el restante monotécico y alternipétalo), insertados cerca de la fauce del hipanto; ovario ovoide, de 5-8 x 2,5-3,5 mm, base redondeada, ápice atenuado, glabro, lustroso, 2-placentífero; estilo columnar, delgado, ca. 2,5 mm de largo, glabro, con 2 ramas bien diferenciadas, usualmente divergentes; estigmas oscuramente 2-lobulados, papilosos. Fruto pauciseminado, ovoide, de 10-23 x 3-10 mm de largo, apiculado y rostrado, lustroso, verde brillante al principio, tornándose escarlata brillante al madurar. Semillas piriformes, de 5-6 x 3-4 mm x 1-1,5 mm de grosor, lisas, castañas, excepto en el borde sagital donde es blanco cremoso, en la porción hilar el borde sagital es más notorio en relieve. 


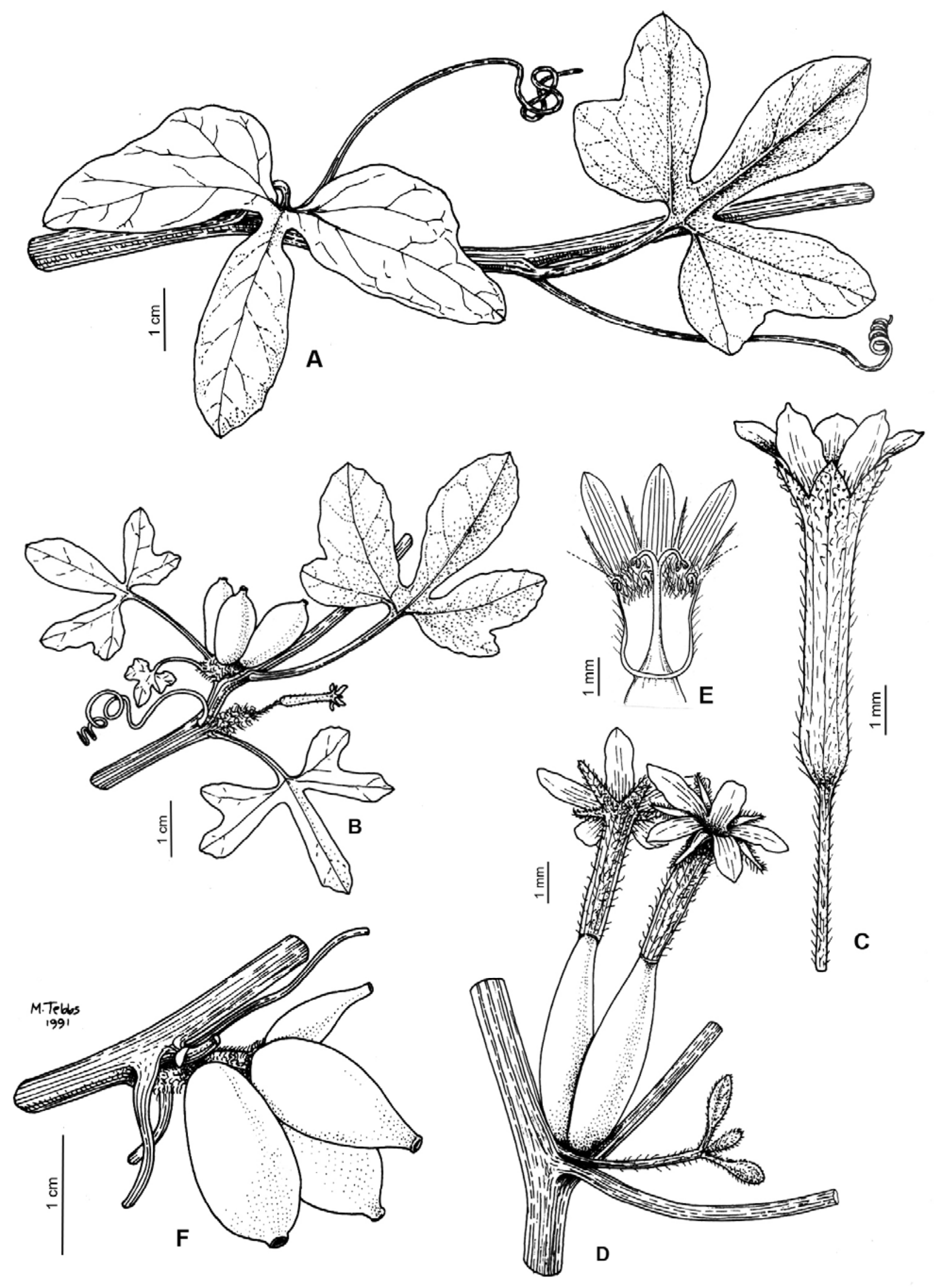

Figura 64. Pseudoapodanthera hindi. A. Porción de un tallo con hojas y zarcillos simples. B. Porción de un tallo con inflorescencia estaminada y frutos. C. Flor estaminada, vista lateral. D. Inflorescencia carpelada. E. Flor carpelada, corte longitudinal del hipanto. F. Frutos. (A-D, F tomado de Jeffrey, 1992; E dibujo de M. J. Belgrano). 
Distribución geográfica y hábitat. Endémica del estado de Bahia (Brasil), crece en laderas rocosas o sobre terrenos arenosos con afloramientos rocosos, en áreas de vegetación abierta, entre 1000-1600 m s.m. (Figura 65).

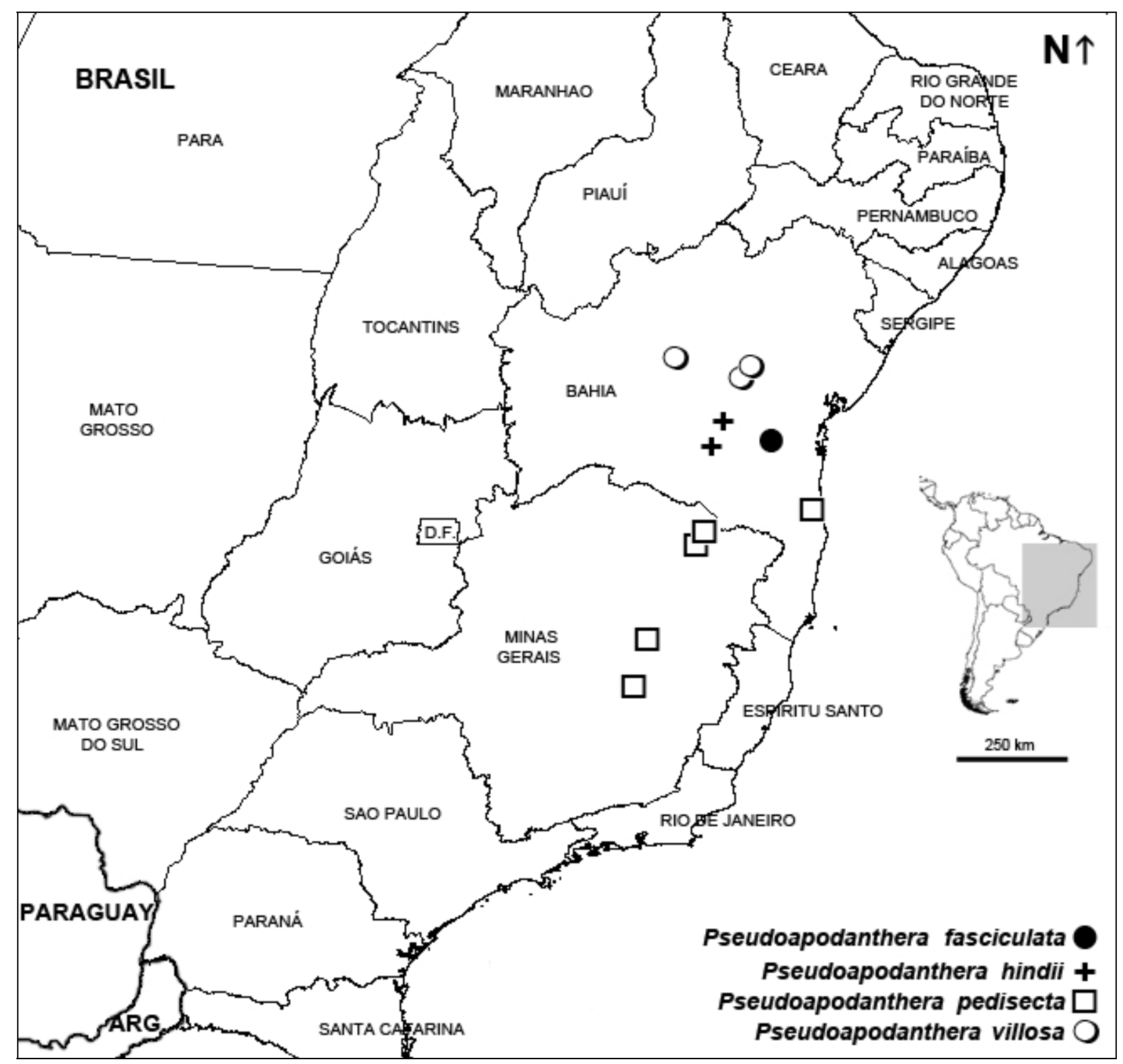

Figura 65. Distribución goegráfica de Pseudoapodanthera fasciculata, P. hindii, P. pedisecta y P. villosa.

Etimología. La especie fue nombrada en honor de David J. N. Hind (1957-), botánico británico, quien llevara adelante numerosas expediciones de colección botánica a Brasil.

Fenología. Coleccionada en flor y fruto en distintas épocas del año (marzo, agosto, noviembre).

Observación. Pseudoapodanthera hindii es muy similar a P. villosa, y sólo se las puede diferenciar por la densidad del indumento externo de las flores (ralo en la primera, profuso en la segunda) y por la cantidad de flores carpeladas en la inflorescencia (1-5 en la primera, 7-30 en la segunda); ambas especies habitan en ambientes similares. Futuros estudios de las 
poblaciones naturales y de un mayor número de especímenes permitirán corroborar que se trata de especies distintas o no.

Material adicional examinado. BRASIL. Bahia. Mun. Mucugé: Serra do Sincorá, $6 \mathrm{~km}$ SW of Mucugé on the Cascavel road, 27 Mar 1980, R. M. Harley et al. 21029 (CEPEC, NY). Mun. Rio de Contas: na subida para o Campo do Queiroz e Pico das Almas, 1500 m s.m., 3 Ago 1998, A.

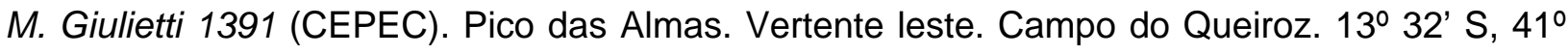
57' W, 1500 m s.m., 3 Nov 1988, R. M. Harley et al. 25895 (CEPEC, K, SI).

3. Pseudoapodanthera pedisecta (Cogn.) Belgrano, comb. nov. Basónimo: Apodanthera pedisecta Cogn., Mém. Couronnes Autres Mém. Acad. Roy. Sci. Belgique 27: 39. 1877. TIPO. Brasil. Bahia, ad flumen Ilheos, Princ. Max von Wied-Neuwied s.n. (holotipo, BR8411983!). Figura 66.

Anguria pedisecta Nees \& Mart., Nova Acta Phys.-Med. Acad. Caes. Leop.-Carol. Nat. Cur. 12: 10. 1824, nom. illeg.

Apodanthera bradei Mart.Crov., Notul. Syst. (Paris) 15: 44. 1954, "Brasil: Minas Gerais, Rodeador, leg. A. C. Brade no 13507, VI-1934 (RB, typus speciei)". TIPO. Brasil. Minas Gerais. Cons. Matta-Rodeador, Jun 1934, A. C. Brade 13507 (holotipo, RB-28413!; isotipo, B-10 0239675!). Pro syn., Paiva Lima (2010: 75).

Apodanthera hatschbachii C. Jeffrey, Kew Bull. 47: 521. 1992, "Brazil, Bahia, Nova Vista, Hatschbach \& Kummrow 48074 (holotypus CEPEC!, isotypus K!)". TIPO. Brasil. Bahia. Mun. Andaraí, Nova Vista; caatinga; escandente, flor amarela, 19 Jun 1984, G. Hatschbach \& R. Kummrow 48074 (lectotipo aquí designado, CEPEC-43513! la rama de la derecha de la hoja; isotipos, K-430954!, MBM!). Pro syn., Paiva Lima (2010: 75).

Subarbustos, diclino-monoicos, zarcillosos; raíces tuberosas, con la porción apical expuesta sobre la superficie; tallos usualmente suculentos, se tornan leñosos hacia la base, pilosos, más densamente en las partes jóvenes y cerca de los nudos, tornándose glabrescentes con la edad, estriados, de 1,5-4 mm de diámetro; entrenudos de 2-11 cm de largo, ligeramente dispuestos en zig-zag. Hojas pecioladas, usualmente caducas al madurar las flores y frutos; pecíolos enangostados hacia el ápice, estriados, ralamente pilosos a glabrescentes, hasta de 4,3 cm de largo; láminas de contorno anchamente ovado a subpentagonal, de 9-10,5 x 9,5-13 cm, base amplia y profundamente cordada, pedatisectas, con 5 segmentos oblongo-obovados $u$ oblanceolados, de ápice agudo a obtuso, mucronulado, de borde subentero a dentado hacia el ápice, remotamente denticulados (hidátodos), la cara adaxial verde, algo escabrósula por presencia de tricomas eglandulares, cónicos, cortos y robustos, de base multicelular 
persistente, cara abaxial algo más pálida, ligeramente tomentosa, con tricomas cónicos de base unicelular, delgados, con célula apical aguda, adpresos; el lóbulo central entero, de 4,5-10 x 1,5-3,5 cm, los laterales similares, algo menores, a veces los más externos ligeramente 2lobulados, senos entre los lóbulos agudos o redondeados. Zarcillos simples, robustos, se tornan leñosos, articulados cerca de la base y caedizos, la base persistente, cónica (a veces semejan aguijones luego de caídos los zarcillos). Inflorescencia estaminada con aspecto de racimo congesto, pedunculada (algunas veces los entrenudos del extremo del tallo son muy breves y el conjunto de racimos que crecen en cada nudo confiere aspecto paniculiforme); pedúnculo estriado, usualmente breve, hasta $1 \mathrm{~cm}$ de largo, pudiendo alcanzar hasta de $6 \mathrm{~cm}$; eje algo engrosado entre las flores, villósulo, con tricomas cónicos de base unicelular. Flores estaminadas numerosas en cada inflorescencia, ebracteadas, pediceladas, de color amarillo brillante (en hipanto, sépalos y pétalos) tornándose algo anaranjadas; pedicelos filiformes, hasta de $9 \mathrm{~mm}$ de largo, villoso-ascendentes, persistentes, articulados en el ápice, algo ensanchados en el ápice; hipanto subcilíndrico-infundibuliforme, de 6-8 mm de largo x 2-3 mm de ancho en base y ápice, más angosto en el medio, redondeado en la base por presencia de nectario mesenquemático craso, exteriormente el hipanto es glabro, villoso-lanoso en el interior a media altura del tubo, por debajo de los estambres, con tricomas eglandulares simples, filiformes, entrelazados; sépalos angostamente triangular-lanceolados a linear-lanceolados 0 subulados, de 1,5-2,5 x ca. 1,5 mm, glabros, algo reflexos; petalos ensiformes, de 2,5-3 x 1,5 $\mathrm{mm}$, ápice usualmente agudo, algo redondeado e induplicado, villosos en la cara interna, diminuta y obscuramente pubescentes en la exterior, con 5 nervios paralelos; estambres insertados hacia la fauce del hipanto, opositipétalos, resultando parcialmente exertos; filamento brevísimo, glabro; anteras botuliformes, rectas, de 3,7-4 mm de largo; conectivo angosto, glabro, no expandido en el ápice. Inflorescencia carpelada fasciculiforme o cortamente espiciforme, pluriflora, con eje breve, engrosado, profusamente blanco-lanoso, con tricomas eglandulares, breves, agudos, entrelazados. Flores carpeladas subsésiles, amarillas; pedicelos brevísimos (ca. $1 \mathrm{~mm}$ de largo), densamente lanosos; hipanto subcilíndrico, de 1,5 × $1 \mathrm{~mm}$, exteriormente glabro, interiormente lanoso cerca de la fauce, con tricomas eglandulares simples, filiformes, agudos; sépalos angostamente lanceolados a subulados, de 1-1,5 x $1 \mathrm{~mm}$, glabros; pétalos ensiformes, ca. $3 \times 1 \mathrm{~mm}$, corta y oscuramente pubescentes en ambas caras, con 5 nervios paralelos entre sí; estaminodios 3, alternipétalos, setiformes, 2 de ellos algo aproximados entre sí, insertados cerca de la fauce del hipanto, en la porción villoso-lanosa del mismo; ovario angostamente elipsoide, ca. 2,5 x $1 \mathrm{~mm}$, base y ápice truncados, glabro, 2placentífero; estilo columnar, ca. $2 \mathrm{~mm}$ de largo, glabro, con 2 ramas bien diferenciadas, usualmente divergentes; estigmas obscuramente 2-lobulados, papilosos. Fruto pauceiseminado, elipsoide, de 10-16 x 3-10 mm, cortamente apiculado y rostrado, lustroso, verde brillante al principio, tornándose rojo al madurar, toruloso al madurar las semillas. Semillas 4-12, piriformes, algo comprimidas en el plano sagital, de 5-5,5 × $3 \mathrm{~mm}$, lisas, 
castañas, blanco-cremoso en el borde sagital, emarginadas, excepto hacia la región hilar donde el margen es más notorio en relieve.

Distribución geográfica y hábitat. Especie endémica de los estados brasileños de Bahia y Minas Gerais (Figura 65). Crece en zonas de Caatinga perturbarda con afloramientos rocosos dispersos, a elevaciones cercanas a los 600 m s.m.

Nombre vulgar. "Abobra do mato" [Saint Hilaire B1 1581 (P)].

Etimología. El epíteto específico hace referencia a las hojas pedisectas.

Fenología. Coleccionada en flor y fruto en distintos momentos del año (febrero, junio, octubre).

Observación 1. Al fundar el binomio Anguria pedisecta Nees \& Martius colocaron a Momordica pedata L. en la sinonimia, resultando por lo tanto en un nombre ilegítimo (CINB Art. 52); el primer nombre válidamente publicado para este taxón corresponde entonces al de Cogniaux (Apodanthera pedisecta, 1877), según el CINB (Art. 58).

Observacion 2. En el ejemplar indicado como holotipo de Apodanthera hatschbachii se observa mezcla de material; en efecto, sólo la rama montada a la derecha de la hoja corresponde a esta especie, la rama de la izquierda pertenece a una especie del género Passiflora. Por este motivo, de acuerdo a lo indicado en el CINM (Arts. 9.9, 9.12), se procedió a la lectotipificación.

Observación 3. Cogniaux (1916) colocó erróneamente a esta especie en la sección tipo del género Apodanthera, aunque reconociendo no haber estudiados las flores carpeladas.

Observación 4. Jeffrey (1992) no trató a esta especie entre las especies de Apodanthera de Bahia (Brasil), a pesar de que el ejemplar tipo de la especie proviene de ese estado brasileño.

Observación 5. Se distingue fácilmente de las demás especies de Pseudoapodanthera por sus inflorescencias estaminadas con aspecto de racimo congesto, pedunculado (vs. fasciculiformes o racemiforme, sésil, en las demás) y sus hojas pedatisectas (vs. profundamente lobadas).

Material adicional examinado. BRASIL. Minas Gerais. Sin localidad consignada, 1816-1821, A. Saint Hilaire B1 1581 (BR, P). Mun. Medina: Morro Agudo, 19 Feb 1989, G. Hatschbach \& J. Cordeiro 52706 (CTES, US). Mun. Pedra Azul: ca. 5 km NW da cidade em direção á BR-116, 10 Feb 1994, V. C. Souza et al. 5154 (F, K). $10 \mathrm{~km}$ ao leste da cidade, na estrada para

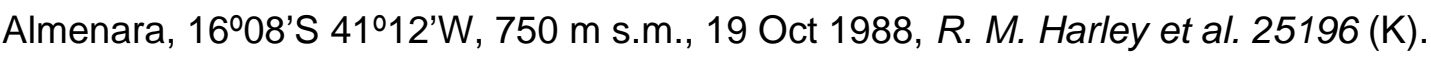




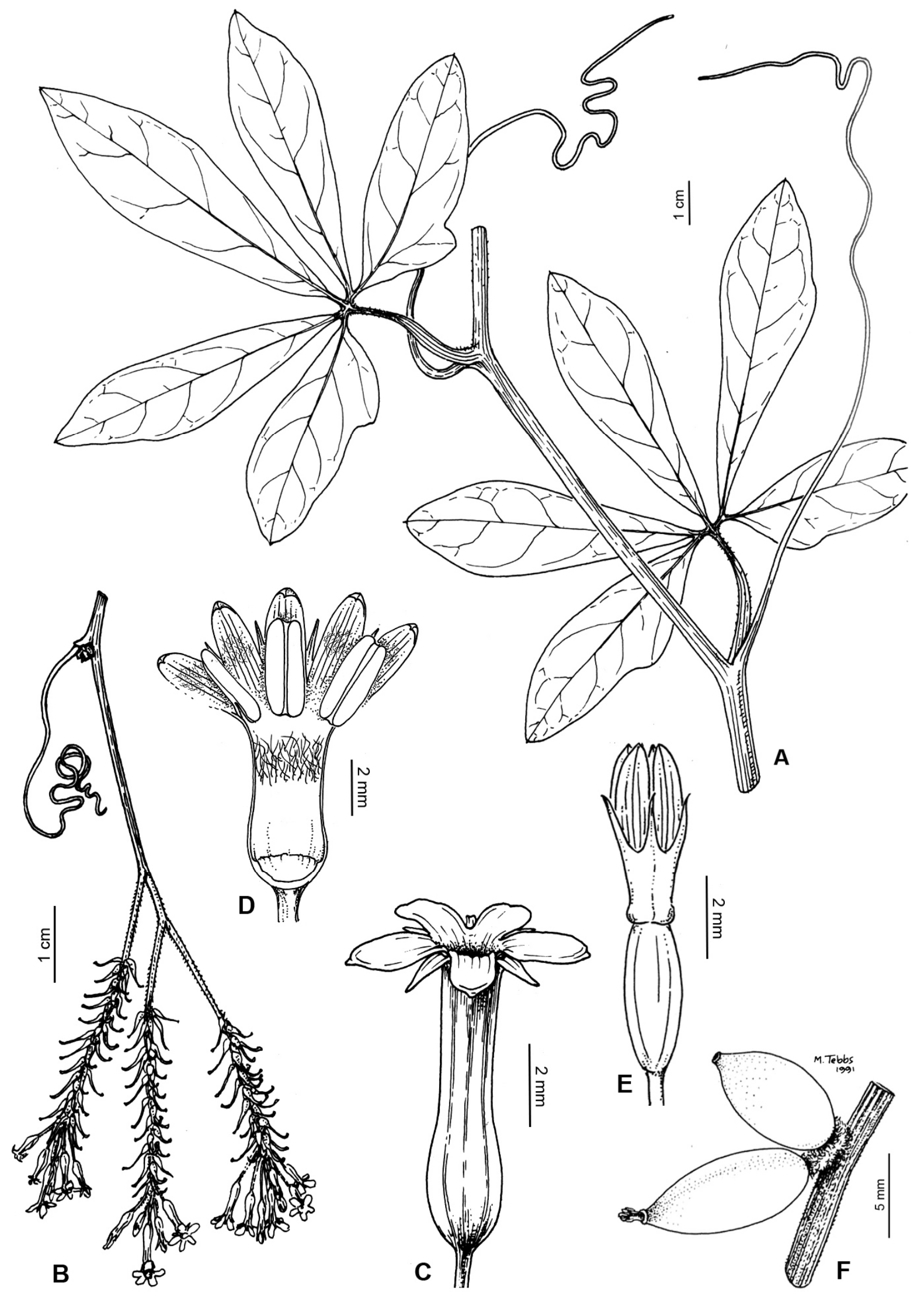

Figura 66. Pseudoapodanthera pedisecta. A. Porción del tallo con hojas y zarcillos simples. B. Inflorescencias estaminadas racemiformes, los entrenudos del extremo del tallo son muy breves y el conjunto de racimos en cada nudo confiere aspecto paniculiforme. C. Flor estaminada, vista lateral. D. Flor estaminada, vista interna. E. Flor carpelada, vista lateral. F. Frutos. (A-C, F tomados de Jeffrey, 1992; D-E dibujo de M. J. Belgrano). 
4. Pseudoapodanthera villosa (C. Jeffrey) Belgrano, comb. nov. Basónimo: Apodanthera villosa C. Jeffrey, Kew Bull. 47: 523, f. 4. 1992, "Brazil, Bahia, Morro de Chapéu, Harley et al. 22753 (holotypus K!)". TIPO. Brasil. Bahia. Mun. Morro do Chapéu, summit of Morro do Chapéu, c. $8 \mathrm{~km} \mathrm{SW}$ of the town of Morro do Chapéu W of road to Utinga; sandstone rocks, with open sand in flatter areas; open scrub in exposed sites to scattered low woodland and marsh, 1000 m s.m., $11^{\circ} 35^{\prime}$ S, 410 12' W, 30 May 1980, R. M. Harley, G. L. Bromley, A. M. De. Carvalho, J. M. Soares Nuñez, J. L. Hage \& E. B. Dos Santos 22753 (holotipo, K-430964!; isotipo, CEPEC-31742!). Figuras 67 y 68.

Apodanthera succulenta C. Jeffrey, Kew Bull. 47(3): 521. 1992, "Brazil, Bahia, near Gentio do Ouro, Harley et al. 18955 (holotypus CEPEC!, isotypi K!, NY, SPF, U)". TIPO. Brasil. Bahia, c. 4 km NE from Gentio do Ouro along the road towards Central; caatinga on sand and with quartzitic rocks and metamorphosed sandstones forming rock area with more open vegetation including extensive areas of Vellozia, approx. $11^{\circ} 24^{\prime} \mathrm{S}, 42^{\circ} 30^{\prime} \mathrm{W}, 1000$ m s.m., 22 Feb 1977, R. M. Harley, S. J. Mayo, R. M. Storr, T. S. Dos Santos \& R. S. Pinheiro 18955 (holotipo, CEPEC-19298!; isotipos, K-430965!, NY-579132!). Syn. nov.

Subarbustos perennes, diclino-monoicos, zarcillosos; raíces tuberosas, con la porción apical expuesta sobre la superficie; tallos usualmente suculentos, subleñosos hacia la base, glabrescentes, verdes a glaucos hacia la porción basal, anaranjados hacia el extremo superior, a menudo el extremo distal del tallo se seca y se desprende al madurar los frutos; entrenudos de 4-11,5 cm de largo, obscuramente dispuestos en zig-zag. Hojas pecioladas, fácilmente caducas; pecíolos gráciles, estriados, de 1,5-5,1 cm de largo, glabrescentes a ralamente pilosos, con algunos tricomas eglandulares uniseriados, cónicos, agudos, algo adpresoascendentes, principalmente hacia el ápice; láminas de contorno anchamente ovado o subpentagonal, de 3,7-6,7 x 4,5-7,5 cm, profundamente 3(-5)-lobadas, base ampliamente cordada, verdes en ambas caras, más pálidamente en la abaxial, con abundantes tricomas cónicos de base unicelular, algo erectos o ligeramente curvados en la cara adaxial, más profusos, marcadamente adpresos y entrelazados en la abaxial; lóbulos de ápice agudo a redondeado, mucronulado, el margen entero o cortamente dentado hacia la mitad superior, remotamente denticulado (hidátodos), el lóbulo central entero, ovado, obovado a elíptico, de 2,3-4,2 x 1,3-2 cm, enangostado y algo decurrente en la base, los 2 lóbulos laterales similares en contorno y dimensiones, a menudo 2-lobulados, senos entre los lóbulos cerrados a extendidos. Zarcillos simples, robustos, se tornan leñosos, articulados cerca de la base y caedizos, glabrescentes. Inflorescencia estaminada fasciculiforme o con aspecto de racimo congesto, sésil, pluriflora; pedúnculo reducido o apenas desarrollado (hasta de $8 \mathrm{~mm}$ de largo), ralamente ascendente-villoso. Flores estaminadas numerosas, ebracteadas, de color amarillo; pedicelos filiformes, hasta de $6 \mathrm{~mm}$ de largo, persistentes, articulados en el ápice, villoso- 
ascendentes, con tricomas eglandulares filiformes, agudos; hipanto subcilíndricoinfundibuliforme, de 6-10 x 2,5-4 mm, más angosto en el medio, redondeado en la base, con nectario mesenquemático basal, cupuliforme y craso, la coloración del hipanto es amarillo brillante, exteriormente densamente villoso, con tricomas eglandulares filiformes, agudos, blanquecinos, erecto-ascendentes, hasta de $2 \mathrm{~mm}$ de largo, en el interior el hipanto es villosolanoso a media altura del tubo, por debajo de los estambres, con tricomas filiformes entrelazados; sépalos angostamente triangular-lanceolados, de 2-2,5 mm de largo x ca. $1 \mathrm{~mm}$ hacia la base, densamente villosos externamente como el hipanto, glabros interiormente, algo reflexos; petalos ensiformes, de 2,5-4 x 1,5-2 mm, amarillos, ápice usualmente agudo, algo induplicado, glabrescentes, con 5 nervios paralelos; estambres insertados cerca de la fauce, resultando su porción superior exerta; filamento brevísimo, glabro; anteras botuliformes, rectas, ca. $3 \mathrm{~mm}$ de largo; conectivo muy angosto, glabro, no extendido en el ápice. Inflorescencia carpelada similar en estructura a la estaminada, multiflora, (hasta ca. 30-floras). Flores carpeladas subsésiles, amarillas; hipanto subcilíndrico, algo más ancho hacia el ápice, de 2,54,5 x 2-2,5 mm, con indumento externo e interno similar al de las flores estaminadas; sépalos angostamente lanceolados, los márgenes algo plegados hacia adentro, ca. $2 \mathrm{~mm}$ de largo, densamente villosos en la cara externa, glabros internamente; pétalos ensiformes a oblongoensiformes, de 3-4 x 1-1,25 mm, oscuramente puberulentos en ambas caras, con 5 nervios paralelos; estaminodios 3 , subtriangulares o setiformes, insertados cerca de la fauce del hipanto, en la porción villoso-lanosa del mismo; ovario ovoide, ca. $6 \times 3 \mathrm{~mm}$, base redondeada, atenuado hacia el ápice, glabro, lustroso, 2-placentífero; estilo columnar, ca. 5,5 mm de largo, glabro, con 2 ramas bien diferenciadas, divergentes; estigmas 2-fidos, papilosos. Fruto ovoide, de 10-14 mm de largo x 5-7 mm de ancho en la base, apiculado y rostrado, lustroso, verde brillante al principio, tornándose escarlata brillante al madurar. Semillas piriformes, ca. 5 × 3 $\mathrm{mm}$, castañas, de superficie lisa, emarginadas, excepto hacia la porción hilar donde el margen sagital es más notorio en relieve y de color blanco-cremoso.

Distribución geográfica y hábitat. Endémica del centro-este del estado de Bahia, Brasil, de donde provienen todas las colecciones correspondientes a esta especie (Figura 65). Habita en los denominados "campos rupestres", entre los 900 y 1100 m s.m., sobre suelos arenosos, con rocas en superficie, donde se desarrolla una vegetación arbustiva xerófila junto con algunos elementos arbóreos. Se trata de una especie de rara ocurrencia, heliófila, que se extiende sobre las rocas o sobre la vegetación hasta alcanzar sitios expuestos.

Etimología. El epíteto específico hace referencia al indumento villoso del hipanto y sépalos de las flores de ambos tipos (estamindas y carpeladas).

Fenología. Encontrada en flor y fruto entre mayo y noviembre. 


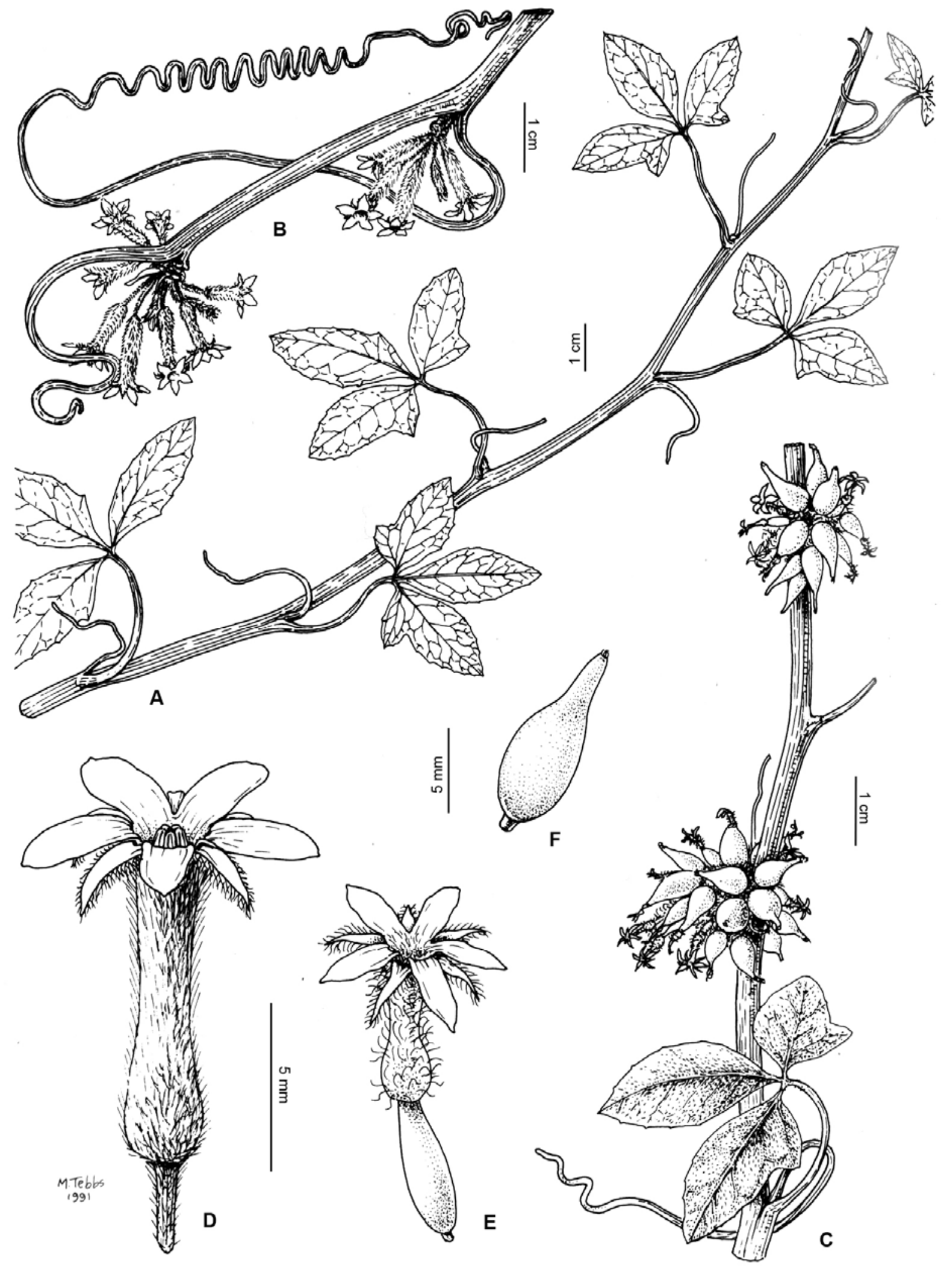

Figura 67. Pseudoapodanthera villosa. A. Porción de un tallo con hojas y zarcillos. B. Porción de un tallo con inflorescencias estaminadas. C. Porción de un tallo con frutos. D. Flor estaminada, vista lateral. E. Flor carpelada, vista lateral. F. Fruto. (Tomado de Jeffrey, 1992). 
Observación 1. Lima Paiva (2010: 77) considera a Apodanthera succulenta como una especie independiente, criterio que no se comparte en este tratamiento. La suculencia de los tallos no es suficiente para distinguir especies dentro de este género por cuanto esta condición se observa a menudo en todas ellas. Por lo demás, no existen diferencias significativas que permitan separarla de $P$. villosa.

Observación 2. Pseudoapodanthera villosa es muy similar a $P$. hindii (véanse comentarios bajo esta última especie).

Material adicional examinado. BRASIL. Bahia. Mun. Morro do Chapéu: Ca. $22 \mathrm{~km}$ W of Morro do Chapéu, 1000 m s.m, 20 Feb 1971, H. S. Irwin et al. 32643 (K). Rio Ferro Doido, próximo à Cachoeira, 11037'15"S 4059'46"W, 879 m s.m., 28 Nov 2003, A. M. Amorim \& M. J. Belgrano 3880 (CEPEC). Rio do Ferro Doido, $19.5 \mathrm{~km}$ SE of Morro do Chapéu on the BA-052 highway to

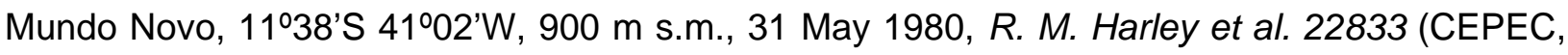

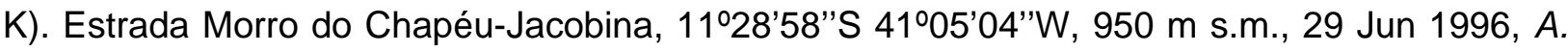
M. Giulietti et al. 3262 (CEPEC). Cachoeira do Ferro Doido, Rod. BA-052, Morro do Chapéu/Mundo Novo, ca. 12 km E, 11037'29"S 4059'57'W, 870 m s.m., 29 Sep 2002, J. G. Jardim et al. 4003 (CEPEC). 12 km na estrada Morro do Chapéu-Ferro Doido, 11034'55"S 41ํ6'W, 1000 m s.m., 28 Jun 1996, H. P. Bautista \& S. Smith 3132 (CEPEC). Serra do Tombador, 1100 m s.m., 15 Jul 1979, G. Hatschbach \& O. Guimarães 42344 (CTES, MO, NY, UC). 


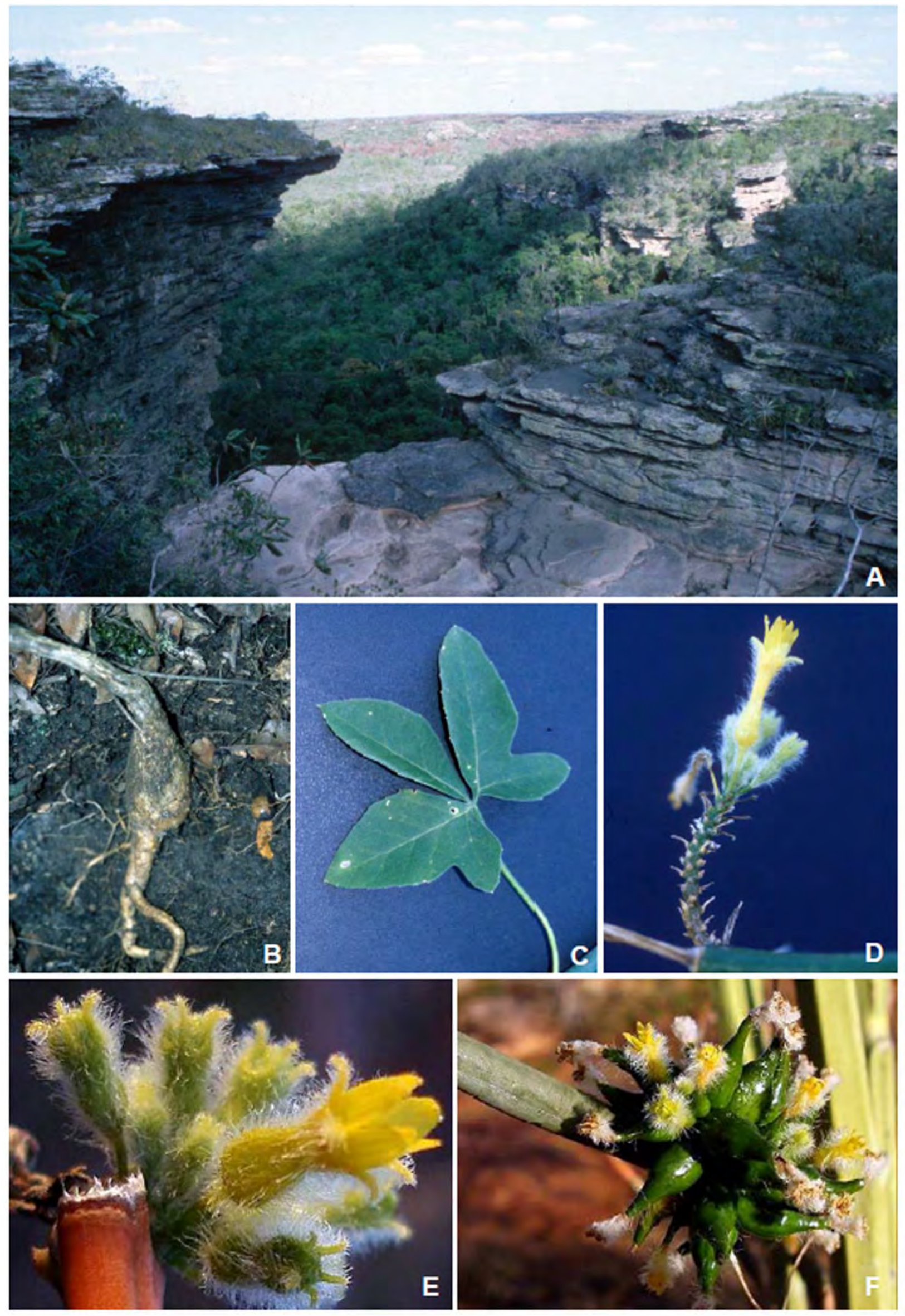

Figura 68. Pseudoapodanthera. Pseudoapodanthera villosa. A. Hábitat: Cachoeira do Ferro Doido, Morro do Chapeu (Bahia, Brasil). B. Raiz tuberosa. C. Hoja. D-E. Inflorescencia estaminado, el tallo se ha secado y caído. F. Frutos. (Fotos: A-D, M. J. Belgrano, de Amorim \& Belgrano 3880, CEPEC; E-F, tomadas de Machado 2009). 


\section{Comentarios biogeográficos}

La reconstrucción filogenética obtenida en esta tesis (Figura 19, página 42) evidenció la polifilia de Apodanthera y mostró el agrupamiento de muchas de sus especies con otros géneros de Coniandreae. Esta situación obligó a redefinir los límites de Apodanthera y de otros géneros afines de la tribu, según se especificó en el Capítulo 4 (Tratamiento taxonómico). Al comparar el patrón filogenético y la distribución geográfica de los géneros tratados (Figura 69), si bien en los niveles más basales la topografía muestra poca resolución de grupos, puede observarse a primera vista que existe correlación entre ambos, a saber:

Apodanthera está asociado exclusivamente al sistema andino, habitando en las laderas expuestas, secas y pedregosas de los cerros de elevación moderada en el norte de Perú (400900 m s.m.), con precipitaciones escasas, influenciadas por las corrientes marinas, y en los Andes centrales de Perú, Bolivia y el noroeste de la Argentina, a elevaciones mayores (18003500 m s.m.).

Cucurbitopsis habita en zonas desérticas y semidesérticas de América del Norte, desde el sur de Estados Unidos (Nuevo México, Arizona y Texas) hasta el centro-sur de México (Oaxaca); crece en planicies aluvionales con cenizas volcánicas, en el desierto de Sonora, en cercanías del golfo de México y en las sierras centrales de México, hasta el estado de Oaxaca, entre 1000-2300 m s.m.

Doyerea muestra una distribución disyunta, con una especie de amplia distribución circuncaribe (D. emetocathartica) y otra (D. trifoliata) restringida el nordeste de Brasil, en la Caatinga. No sería extraño que esta disyunción sea aparente y que se deba a un muestreo deficiente en el norte de Brasil y las Guayanas.

Melothrianthus se distribuye en Sudamérica, asociado a los sistemas montañosos del este de Brasil, desde el estado de Paraíba en el nordeste, hasta São Paulo, a elevaciones cercanas a los 1000 m s.m. Una de sus especies ( $M$. sagittifolius) posee una amplia distribución geográfica, desde el extremo sur de Brasil y hacia el sur hasta el centro de la Argentina, en la localidad de Carmen de Patagones (se trata de la especie de distribución más austral de la familia); ocupa ambientes diversos, algunos montañosos, como las sierras bonaerenses, las serranías centrales de Córdoba, la precordillera andina de las provincias de la Rioja y San Juan (hasta los 2800 m s.m.), y otros, en cambio, ribereños o de la costa atlántica del sur de la provincia de Buenos Aires.

Pseudoapodanthera es endémico del nordeste de Brasil, exclusivamente en los estados de Bahia y Minas Gerais, en ambientes xéricos de la Caatinga y en los campos rupestres, entre 900-1600 m s.m. 
Las especies de posición genérica incierta, en tanto, se distribuyen: Apodanthera anatuyana, en el Chaco seco del sur de Bolivia y norte de la Argentina; A. biflora, en áreas costeras de Ecuador y norte de Perú, con clima influenciado por las corrientes marinas; $A$. cinerea, únicamente en las Salinas de Pilluana, en el norte de Perú; $A$. laciniosa, en las selvas montantas del sudeste de Brasil; y A. ulei, en zonas costeras y selvas del litoral atlántico del sudeste de Brasil.

Las áreas de dispersión de estos cinco géneros prácticamente no se superponen, a excepción de lo que ocurre en el este de Brasil; en efecto, en el nordeste son simpátricos Doyerea (con $D$. trifoliata), Melotrhianthus y Pseudoapodanthera; en el sudeste, lo son Melothrianthus, Apodanthera laciniosa y $A$. ulei.

En el centro de México, se superponen ligeramente Cucurbitopsis (con C. aspera) y Doyerea (con D. emetocathartica).

Doyerea y Pseuodapodanthera son grupos hermanos y son simpátricos en el nordeste de Brasil, ocupando los mismos tipos de ambiente. Ambos géneros se agrupan con otros también sudamericanos: Psiguria, Helmontia, Gurania, Wilbrandia y, más basalmente, Ceratosanthes.

Los géneros sudamericanos de Coniandreae se habrían originado de unos pocos eventos de dispersión transoceánica desde África (Schaefer \& Renner 2009, 2011b). En la filogenia, algunos clados incluyen géneros tanto africanos como neotropicales.

Melothrianthus, que se extiende desde el nordeste de Brasil hasta el centro de la Argentina, aparece emparentado con Halosicyos, género monotípico, endémico de suelos salobres del centro de la Argentina, y con los géneros africanos Seyrigia y Corallocarpus.

Doyerea, Pseudoapodanthera y Melothrianthus, junto con Apodanthera anatuyana y A. ulei, integran un gran clado que incluye géneros americanos y africanos. En la base de este clado se ubican Trochomeriopsis Cogn., monotípico y endémico de Madagascar, e Ibervillea lindheimeri (A. Gray) Greene, de América del Norte.

Un caso que merece especial consideración es el de Cucurbitopsis, propio de ambientes áridos de América del Norte, que en la filogenia obtenida forma grupo hermano con el género monotípico Cucurbitella, de Sudamérica. Ambos géneros son morfológicamente similares (véase observación en página 113) y ocupan ambientes similares. Estudios más profundos permitirían corroborar que se trata de géneros independientes o, contrariamente, que son uno, de distribución anfitrópica. Disyunciones de este tipo han sido extensamente documentadas para diversos taxones, por ejemplo Larrea Cav. (Zygophyllaceae) (Hunziker et al. 1972) o Gridellia Willd. (Asteraceae) (Moore et al. 2012), entre otros. 


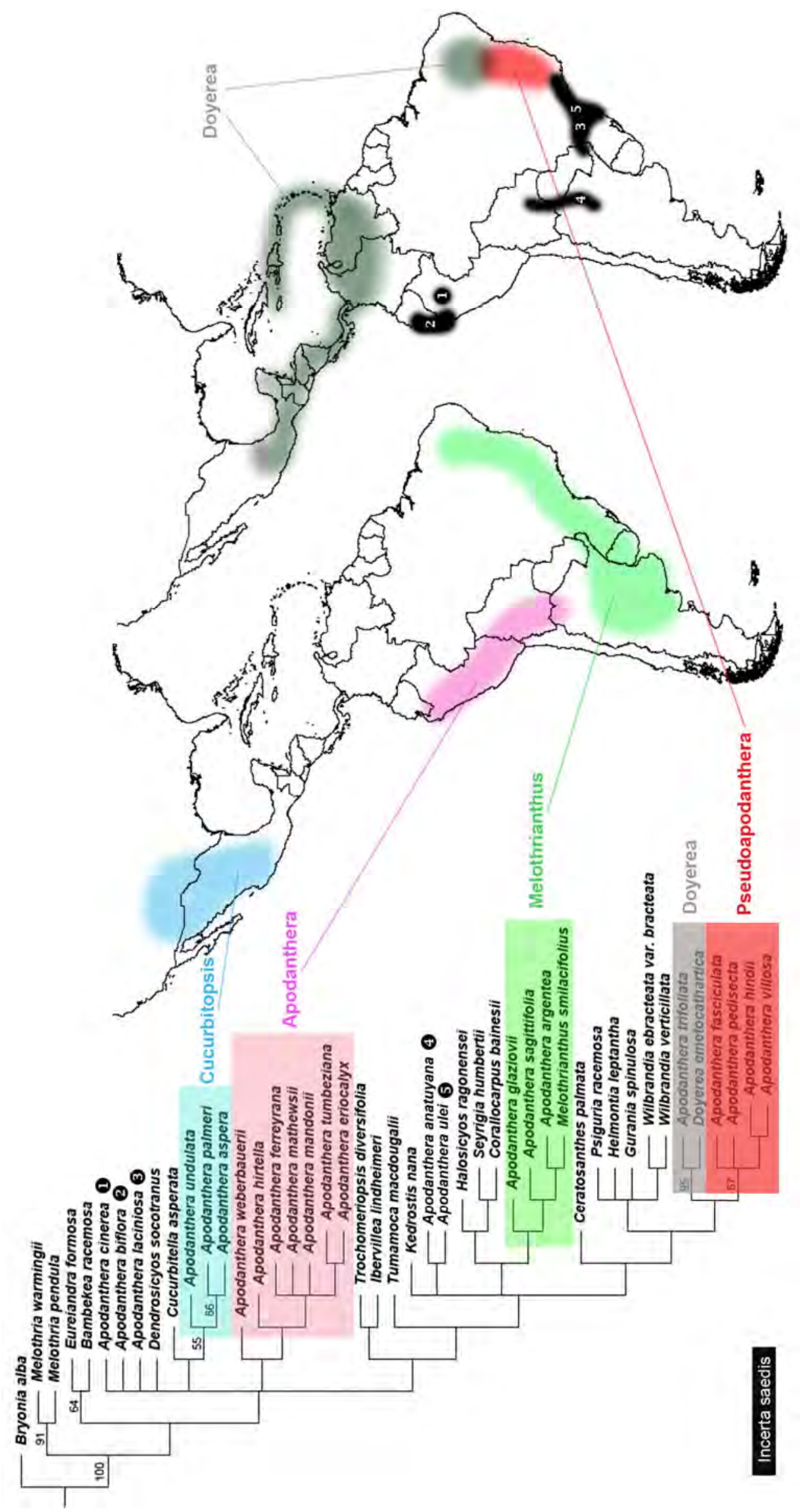

Figura 69. Distribución geográfica de los géneros tratados, su correlación con los patrones filogenéticos. 
Como se mencionó anteriormente, las áreas de dispersión de los géneros tratados prácticamente no se superponen; sin embargo, la mayoría ellas se corresponden con ambientes xéricos, a menudo asociados a sistemas orográficos de mediana y gran altura, con precipitaciones escasas u ocasionales y grandes amplitudes térmicas diarias y estacionales. La excepción son las especies que habitan en el sudeste de Brasil, en donde las condiciones de humedad son mayores y el clima subtropical (Apodanthera lacinionsa, $A$. ulei) y aquellas que habitan áreas cercanas al nivel del mar (como A. biflora en la costa del Pacífico ecuatoriano; Melothrianthus sagittifolius, que dentro de su amplia distribución geográfica habita en las dunas costeras del sur de la provincia de Buenos Aires; o Doyerea emetocathartica, de amplia distribución circuncaribe).

En concordancia con lo anterior, no se han observado adaptaciones morfológicas al ambiente que sean diferenciales entre los géneros tratados. Más bien, todos ellos muestran adaptaciones similares a ambientes xéricos (también presentes en otras familias botánicas), tales como: raíces tuberosas (xilopodios) reservantes, muy desarrolladas; nectarostegio tricomatoso en el interior del hipanto (excepto en las especies de Apodanthera) lo cual evita la evaporación del néctar; o el indumento profuso en las láminas foliares que reduce la pérdida de agua por evaporación (Fahn 1992).

Las adaptaciones más llamativas y extremas a ambientes xéricos se observan en las especies de Doyerea y Pseudoapodanthera. En éstas, los xilopodios tienen gran desarrollo y su porción apical queda expuesta sobre la superficie, la base de los tallos se vuelve leñosa y perenne; las hojas y los zarcillos son fácilmente caducos, resultado los tallos anuales prontamente áfilos, adicionalmente, los extremos de los tallos se desecan y caen a medida que maduran los frutos. 


\section{Conclusiones generales}

Contrastación de hipótesis y principales objetivos alcanzados

- Se confirmó la polifilia del género Apodanthera, como quedó evidenciado a partir de la reconstrucción filogenética obtenida en esta tesis, en concordancia con otras filogenias moleculares recientemente publicadas (Schaefer \& Renner 2009, 2011a). Esta reconstrucción representa una nueva hipótesis filogenética para la tribu Coniandreae, basada tanto en caracteres morfológicos como moleculares (evidencia total).

- Se redefinieron los límites taxonómicos de las especies y taxones infraespecíficos reconocidos dentro de Apodanthera: de los 45 nombres existentes dentro de este género, sólo se aceptan como taxones independientes a 23 (todos en el nivel de especie). Se establecieron 15 nuevas sinonimias taxonómicas, se propusieron 11 nuevas combinaciones en el nivel de especie y se designaron 23 lectotipos.

- Se ajustaron las asignaciones genéricas de las especies tratada, redefiniéndose los límites de Apodanthera y de otros géneros de la tribu Coniandreae:

a) Dentro de Apodanthera se reconocen únicamente a siete especies de filiación andina, que crecen desde el norte de Perú, Bolivia y hasta el noroeste de la Argentina. Cinco especies son consideradas como de posición genérica incierta, por cuanto difieren en su morfología de Apodanthera en el sentido estricto de esta tesis y sus relaciones no quedan resueltas en el estudio filogenético; estas especies aún están incluidas en Apodanthera hasta tanto pueda precisarse su posición genérica.

b) Se fundaron 2 nuevos géneros: Cucurbitopsis, con tres especies de zonas áridas de América del Norte y Pseudoapodanthera, con 4 especies del nordeste de Brasil; ambos géneros fueron escindidos de Apodanthera y corresponden a las antiguas secciones de este género.

c) Se amplió la circunscripción genérica de Doyerea y Melothrianthus, considerados como monoespecíficos hasta esta tesis, por transferencia de cuatro especies ubicadas anteriormente en Apodanthera (una transferida a Doyerea, las restantes tres a Melothrianthus).

- Para distinguir a los géneros y especies tratados (incluyendo a aquellas especies de posición incierta) se elaboraron claves dicotómicas; adicionalmente, se brindaron descripciones botánicas completas, ilustraciones originales (en caso de no existir previamente o no estar disponibles), exsiccata y mapas de distribución; en caso de ser posible, se incluyeron fotografías de campo.

- Se aportó nueva información molecular para 16 especies de Cucurbitaceae (secuencias de genes de cloroplasto rbcL y trnl-F). 
- En la mayoria de los grupos de especies (clados) obtenidos en el estudio filogenético se correlacionan con la distribución geográfica. Las especies más conflictivas en cuanto a su asignación genérica (incerta saedis) crecen en el Chaco seco del sur de Bolivia y norte de la Argentina (Apodanthera anatuyana), zonas costeras de Ecuador y norte de Perú (A. biflora), salinas del norte de Perú $(A$. cinerea) y zonas húmedas, montanas y costeras, del sudeste de Brasil (A. laciniosa y $A$. ulei).

- Se analizó la distribución geográfica de las especies tratadas y las adaptaciones morfológicas a los distintos hábitats. 


\section{Bibliografía citada}

Acevedo Rodríguez, P. 2005. Vines and Climbing Plants of Puerto Rico and the Virgin Islands. Contr. U.N. Natl. Herb. 51: 1-483.

Arnott, G. A. W. 1841. On the Cucurbitaceae. J. Bot. (Hooker) 3(21): 271-280.

Ayala Nieto, M., Lira, R. \& Alvarado, J. L. 1988. Morfología polínica de las Cucurbitaceae de la península de Yucatán. Polen \& Spores 30: 5-28.

Bentham, G. 1844-1846. The Botany of the Voyage of H. M. S. Sulphur. 1-194. Elder Smith, London.

Brack E., A. 2000. Ecología del Perú. 1-500. Ed. Bruño, Lima.

Brandegee, T. S. 1922. PI. Mexicanae Purpusianae, XI. Univ. California Publ. Bot. 10: 181-188.

Cogniaux, A. 1877. Diagnoses de Cucurbitacées nouvelles et observations sur les espèces critiques. Mém. Couronnés Autres Mém. Acad. Roy. Sci. Belgique 28: 1-103.

Cogniaux, A. 1878. Cucurbitaceae. En C. F. P. von Martius (ed.), Fl. Bras. 6(4): 1-126.

Cogniaux, A. 1881. Cucurbitaceae. Monogr. Phanerog. [A. DC. \& C. DC.] 3: 325-947.

Cogniaux, A. 1887. Descriptiones de quelques Cucurbitacées nouvelles. Bull. Acad. Roy. Belgique, Sér. 3, 14: 346-364.

Cogniaux, A. 1891. Cucurbitaceae. En T. Durand \& H. Pittier (eds.), Primitiae Florae Costaricensis. Bull. Soc. Roy. Bot. Belgique 30(1): 271-279.

Cogniaux, A. 1895. Cucurbitaceae. En J. N. Rose, Descriptions of plants, mostly new, from Mexico and the United States. Contr. U.S. Natl. Herb. 3: 311-323.

Cogniaux, A. 1908. Cucurbitaceae peruvianae. En I. Urban (ed.), Plantae novae andinae imprimis Weberbauerianae IV. Bot. Jahrb. Syst. 42: 173-174.

Cogniaux, A. 1913. Cucurbitaceae andinae. En I. Urban (ed.), Plantae novae andinae imprimis Weberbauerianae. VI. Bot. Jahrb. Syst. 50 (Beibl. 111): 75-76.

Cogniaux, A. 1916. Cucurbitaceae. Fevilleae-Melothrieae. Pflanzenr. 66 (IV. 275. I): 1-277.

Condon, M. A. \& Gilbert, L. E. 1988. Sex expression of Gurania and Psiguria (Cucurbitaceae): Neotropical vines that change sex. Amer. J.Bot. 75: 875-884.

Delascio Chitty, F. \& Reyes López, F. 2007. Las Cucurbitáceas del Estado Cojedes, Venezuela. Acta Bot. Venez. 30: 19-41.

Delesalle, V. A. 1987. Patterns and gender allocation in a monoecious cucurbid, Apodanthera undulata, and their reproductive consequences. PhD Dissertation, University of Arizona, Tucson, Arizona.

Delesalle, V. A. 1989. Year to year changes in phenotypic gender in a monoecious cucurbit, Apodanthera undulata. Amer. J. Bot. 76: 30-39.

Delesalle, V. A. 1992. Architecture and gender allocation: Floral sex expression along branches of the monoecious Cucurbit, Apodanthera undulata. Int. J. Plant. Sci. 153(1): 108-113.

Dieterle, J. V. A. 1976. Cucurbitaceae. En D. L. Nash (ed.), Fl. Guatemala 10(4). Fieldiana, Bot. 24(11/4): 306-395. 
Dillon, M. O. \& Hoffmann-J., A. 1997. Lomas formations of the Atacama Desert. En S. D. Davis, V. H. Heywood, O. Herrera-McBryde, J. Villa-Lobos \& A. C. Hamilton (eds.), Centres of Plant Diversity 3, The Americas: 528-535.

Dittmer, H. J. \& Talley, B. P. 1964. Gross morphology of tap roots of desert cucurbits. Bot. Gaz. 125(2): 121-126.

Doyle, J. J. \& Doyle, J. L. 1987. A rapid DNA isolation procedure for small quantities of fresh leaf tissue. Phytochemical Bull. 19: 11-15.

Dukas, R. 1987. Foraging behavior of three bee species in a natural mimicry system: Female flowers which mimic male flowers in Ecballium elaterium (Cucurbitaceae).Oecologia 74: 256-263.

Efroni, I., Eshed, Y. \& Lifschitz, E. 2010. Morphogenesis of simple and compound leaves: a critical review. Plant Cell 22:1019-1032.

Fahn, A. \& Cutler, D. F. 1992. Xerophytes. Hand. Pflanzenanat. 13(3): 1-176.

Ferreyra, R. 1983. Los tipos de vegetación de la costa peruana. Anales Jard. Bot. Madrid 40: 241-256.

Font Quer, P. 1953. Diccionario de botánica. 1-1244. Labor, Barcelona.

Glaziou, A. 1909. Plantae Brasiliae australis a Glaziou lectae. Mém. Soc. Bot. France 3: 1-661.

Goloboff, P., Farris, J. S. \& Nixon, K. C. 2008. TNT a free program for phylogenetic analysis. Cladistics 24 : 1-13.

Gomes-Klein, V. L. 1996. Cucurbitaceae do Estado do Rio de Janeiro: Subtribo Melothriinae E. G. O. Muell et F. Pax. Arq. Jard. Bot. 34: 93-172.

Gray, A. Plantae Wrightianae. II. An account of a collection of plants made by Charles Wright. 1119. Smithsonian Institution, Washington.

Grosourdy, R. 1864. Méd. Bot. Criollo. I. Flora médica y útil de las Antillas. II. Compendio de terapéutica vegetal de las Antillas. F. Brachet, Paris.

Hall, T. A. 1999. BioEdit: a user friendly biological sequence alignment editor and analysis program for Windows 95/98/NT. Nucleid Acids Symposium Series 41: 95-98.

Harms, H. 1934. Cucurbitaceae americanae novae. Notizbl. Bot. Gard. Berlin-Dahlem 11(108): 769-776.

Holmgren, N. H. \& Angell, B. 1986. Botanical Illustration: Preparation for Publication. 1-74. The New York Botanical Garden, Bronx, New York.

Hunziker, J. H., Palacios, R. A., Valeri, A. G. H. \& Poggio, L. 1972. Species disyunction in Larrea - evidence from morphology, cytogenetics, phenolic compounds, and seed albumins. Ann. Missouri Bot. Gard. 59 : 224-233.

Inamdar, J. A. \& Gangadhara, M. 1975. Structure, Ontogeny, Classification and Organographic Distribution of Trichomes in Some Cucurbitaceae. Feddes Repert. 86 : 307-320.

Inamdar, J. A., Gangadhara, M. \& Shenoy, K. N. 1989. Structure, Ontogeny, Organographic Distribution, and Taxonomic Significance of Trichomes and Stomata in the Cucurbitaceae. 
En D. M. Bates, R. W. Robinson \& C. Jeffrey (eds.), Biology and Utilization of the Cucurbitaceae. 209-224. Comstock Publishing Associates, Ithaca \& London.

Jeffrey, C. 1962. Notes on Cucurbitaceae, including a proposed new classification of the family. Kew Bull. 15 : 337-371.

Jeffrey, C. 1967. Cucurbitaceae. En E. Milne-Readhead \& R. M. Polhill (eds.), FI. Trop. E. Africa. 1-156.

Jeffrey, C. 1978. Further notes on Cucurbitaceae. IV. Some New World taxa. Kew Bull. 33 : 347-380.

Jeffrey, C. 1980. A review of the Cucurbitaceae. Bot. J. Linn. Soc. 81: 233-247.

Jeffrey, C. 1990. Appendix: an outline classification of the Cucurbitaceae. En D. M. Bates, R. W.

Robinson \& C. Jeffrey (eds.), Biology and utilization of the Cucurbitaceae. 449-463. Comstock Publication Associates, Cornell University Press, Ithaka.

Jeffrey, C. 1992. The genus Apodanthera (Cucurbitaceae) in Bahia State (Brazil). Kew Bulletin 47(3): 517-528.

Jeffrey, C. 2005. A new system of Cucurbitaceae. Bot. Zhurn. 90: 332-335.

Jeffrey, C. \& Fernandes, R. B. 1986. Cucurbitaceae. En E.Mendes (ed.), FI. Moçambique 1-117.

Jeffrey, C. \& Trujillo, B. 1992. Cucurbitaceae. FI. Venezuela 5(1): 11-201.

Kearns, D. M. 1994a. A revision of Tumamoca (Cucurbitaceae). Madroño 41(1): 23-29.

Kearns, D. M. 1994b. The genus Ibervillea (Cucurbitaceae): An enumeration of the species and two new combinations. Madroño 41: 13-22.

Keraudren, M.1966. Cucurbitaceae. En H. Humbert (ed.), Fl. Madagascar. 1-173.

Keraudren-Aymonin, M. 1975. Cucurbitaceae. FI. Afrique Centrale. 1-152.

Kocyan, A., Zhang. L.-B., Schaefer, H. \& Renner, S. S. 2007. A multi-locus chloroplast phylogeny for the Cucurbitaceae and its implications for character evolution and classification. Molec. Phyl. Evol. 44 : 553-577.

Kumazawa, M. 1964. Morphological interpretations of axillary organs in the Cucurbitaceae. Phytomorphology 14: 287-298.

León, B. 2006. Cucurbitaceae endémicas del Perú. Revis. Peru. Biol. 13(2): 271-274.

Lira, R. 2001. Cucurbitaceae. Fl. Bajío 92: 1-120.

Lira, R. \& Caballero, J. 2002. Ethnobotany of the wild Mexican Cucurbitaceae. Economic Bot. 56: 380-398.

Lira, R. \& Rodríguez Arévalo, I. 1999. Cucurbitaceae. Fl. Valle Tehuacán-Cuicatlán 22: 5-61.

Lira, R \& Rodríguez Arévalo, I. 2006. Catálogo de la familia Cucurbitaceae de México. Universidad Nacional Autónoma de México. 1-86. Informe final SNIB-CONABIO proyecto DS002.

Lira, R., Rodríguez Jiménez, C., Alvarado, J. L., Rodríguez, I. Castrejón, J. \& Domínguez Mariani, A. 1998. Diversidad e importancia de la familia Cucurbitaceae en México. Acta Bot. Mex. 42: 43-77. 
Lundell, C. L. 1945. New American Spermatophytes. Field \& Lab. 13(1): 1-23.

Machado, M. 2009. Apodanthera - Two caduciform cucumbers from Bahia, Brazil. Cactus \& Succulent Society of America 81(3): 147-149.

Macbride, J. F. 1937. Cucurbitaceae, Flora of Peru. Publ. Field Mus. Nat. Hist., Bot. Ser. 13(6/2): 321-383.

MacNeill, J., Barrie, F. R., Burdet, H. M., Demoulin, V., Hawksworth, D. L., Marhold, K., Nicolson, D. H., Prado, J., Silva, P. C., Skog, J. E., Wiersema, J. H. \& Turland, N. J. 2006. International Code of Botanical Nomenclature (Vienna Code). Regnum Vegetabile 146: ixviii + 1-568. Versión on line en: http://ibot.sav.sk/icbn/main.htm

Marticorena, C. 1963. Material para la monografía del polen de Cucurbitaceae. Grana 4: 78-91. Martínez Crovetto, R. 1946. Nota taxonómica sobre Wilbrandia sagittifolia Griseb. (Cucurbitaceae). Bol. Soc. Argent. Bot. 1: 312-317.

Martínez Crovetto, R. 1947. Halosicyos, nuevo género de Cucurbitaceae de la Flora Argentina. Bol. Soc. Argent. Bot. 2: 84-90.

Martínez Crovetto, R. 1949. Las especies argentinas del género Melothria (Cucurbitaceae). Darwiniana 8: 496-518.

Martínez Crovetto, R. 1950. Una nueva especie de Melothria de la flora argentina. Bol. Soc. Argent. Bot. 3: 98-101.

Martínez Crovetto, R. 1953. Nueva Apodanthera (Cucurbitaceae) del sur de Brasil. Dusenia 4: 37-39.

Martínez Crovetto, R. 1954a. Sur les organes femelles de quelques espèces du genre Apodanthera (Cucurbitaceae). Notul. Syst. (Paris) 15: 41-43.

Martínez Crovetto, R 1954b. Especies nuevas o críticas del género Apodanthera (Cucurbitaceae) I. Notul. Syst. (Paris) 15: 44-47.

Martínez Crovetto, R. 1954c. Deux nouveaux genres de Cucurbitacèes de L' Amerique du Sul. Notul. Syst. (Paris) 15: 56-62.

Martínez Crovetto, R 1956. Especies nuevas o críticas del género Apodanthera (Cucurbitaceae) II. Bol. Soc. Argent. Bot. 6: 94-97.

Martínez Crovetto, R. 1960. Rtevisión crítica del género Wilbrandia (Cucurbitaceae). Darwinana 12: $17-42$.

McVaugh, R. 2001. Cucurbitaceae. En R. McVaugh (ed.), FI. Novo-Galiciana 3: 483-652.

Machado, M. 2009. Apodanthera - Two caduciform cucumbers from Bahia, Brazil. Cactus \& Succulent Society of America 81(3): 147-149.

Moon, J. \& Hake, S. 2011. How a leaf gets its shape. Current Opinion in PI. Biology 14: 24-30.

Moore, A. J., Bartoli, A., Tortosa, R. D. \& Baldwin, B. G. 2012. Phylogeny, biogeography, and chromosome evolution of the amphitropical genus Grindelia (Asteraceae) inferred from nuclear ribosomal and chloroplast sequence data. Taxon 61: 211-230.

Nee, M. 1993. Cucurbitaceae. Fl. Veracruz 74: 1-129. 
Nelson, G. 1979. Cladistic analysis and synthesis: principles and definitions, with a historical note on Adanson's Familles des Plantes (1763-1764). Syst. Zool. 28: 1-21.

Nixon, K. C., Carpenter, J. M., 1993. On outgroups. Cladistics 9 : 413-426.

Nixon, K. C., Carpenter, J. M., 1996. On simultaneous analysis. Cladistics 12 : 221-241.

Oluwatosin, O. B. 2002. Inheritance of genes for leaflet shape and leaflet shape modifier in cowpea. African Crop Sci. J. 10: 133-137.

ONERN. 1976. Mapa ecológico del Perú. Guía explicativa. 1-146. Oficina Nacional de Evaluación de Recursos Naturales de Lima.

Paiva Lima, L. F. 2010. Estudos taxonômicos e morfopolinicos em Cucurbitaceae brasileiras. 1232. Tesis doctoral. Instituto de Biociências, Universidade Federal do Rio Grande do Sul, Porto Alegre.

Porto, M. L. 1974. Cucurbitaceae. FI. II. Rio Grande do Sul. Bol. Inst. Central Bioci. 31: 1-64.

Pozner, R. 1993. Sistemas reproductivos en Cucurbitaceae argentinas. Tesis doctoral, Universidad de Buenos Aires.

Pozner, R. 1996. La posición taxonómica de Melothria anatuyana (Cucurbitaceae). Hickenia 2: 185-188.

Pozner, R. 1998a. Revisión del género Cucurbitella (Cucurbitaceae). Ann. Missouri Bot. Gard. 85: 425-438.

Pozner, R. 1998b. Cucurbitaceae. En A. T. Hunziker (ed.), Fl. Fanerog. Argent. 53: 1-58.

Quiroz García, D. L., Hernández, C. L., Arreguín Sánchez, M L. 2003. Morfología de los granos de polen de la familia Cucurbitaceae del estado de Querétaro, México. Polibot. 16: 29-47.

Raunkiaer, C. 1934. The life forms of plants and statistical plant geography. 1-632. The Claredon Press, Oxford.

Rohlf. F. J. 1982. Consensus indices for comparing classifications. Math. Biosci. 59: 131-144.

Roque, A. A., Rocha, R. M., Loiola, M. I. B. 2010. Uso e diversidade de plantas medicinais da Caatinga na comunidade rural de Laginhas, município de Caicó, Rio Grande do Norte (nordeste do Brasil). Rev. Bras. PI. Med., Botucatu 12: 31-42.

Roy, R. P. \& Saran, S. 1990. Sex expression in the Cucurbitaceae. 251-268. En D. M. Bates, R. W. Robinson \& C. Jeffrey (eds.), Biology and utilization of the Cucurbitaceae. Ithaca: Comstock Publ. Associates, Cornell University Press.

Rúa, G. H. 1999. Inflorescencias, bases teóricas para su análisis. 1-100. Sociedad Argentina de Botánica, Buenos Aires.

Schaefer, H. \& Renner, S. S. 2010. A gift from the New World? The West African crop Cucumeropsis mannii and the American Posadaea sphaerocarpa (Cucurbitaceae) are the same species. Syst. Bot. $35: 1-7$.

Schaefer, H. \& Renner, S. S. 2011a. Phylogenetic relationships in the order Cucurbitales and a new classification of the gourd family (Cucurbitaceae). Taxon 60: 122-138. 
Schaefer, H. \& Renner, S. S. 2011b. Cucurbitaceae. En K. Kubitzki (ed.), Families and Genera of Flowering Plants 10: 112-174. Springer Verlag, Berlin.

Schaefer, H., Heibl, C. \& Renner, S. S. 2009. Gourds afloat: a dated phylogeny reveals an Asian origin of the gourd family (Cucurbitaceae) and numerous oversea disperal events. Proc. R. Soc. B. 276: 843-851.

Sousa S., M. 1979. Itinerario botánico de G. Andrieux en México. Taxon 28: 97-102.

Stafleu, F. A. \& Cowan, R. S. 1976-1988. Taxonomic literature. A selective guide to botanical publications and collections with dates, commentaries and types. 2 ed. Vol. 1-7. Ultrecht.

Stafleu, F. A. \& Mennega, E. A. 1992-1997. Taxonomic literature. A selective guide to botanical publications and collections with dates, commentaries and types. Vol. 1-6. Ultrecht.

Stearn, W. T. 1973. Botanical latin. History, Grammar, Syntax, Terminology, and Vocabulary, ed. 2. 1-566. David \& Charles, Newton Abbot.

Steele, P. R. 2010. Taxonomic Revision of the Neotropical Genus Psiguria (Cucurbitaceae). Syst. Bot. 35: 341-357.

Taberlet, P., Gieley, L., Paton, G. \& Bouvet, J. 1991. Universal primers for amplification of three noncoding regions of chloroplast DNA. PI. Molec. Biol. 17: 1105-1109.

Thiers, B. 2012. Index herbariorum. The herbaria of the world: http://sweetgum.nybg.org/ih/

Ule, E. 1908. Die Pflanzenformationen Amazonas-Gabietes. II. Bot. Jahrb. Syst. 40 : 399-443.

Venning, F. D. 1953. Manual of Advanced Plant Microtechnique. Wm. C. Brown Company, Publishers, Dubuque, lowa.

Vogel, S. 1997. Remarkable nectaries: structure, ecology, organophyletic perspectives. I. Substitute nectaries. Flora 192: 305-333.

Watson, S. 1889. Contributions to American botany. 1. Upon a collection of plants made by Dr. E. Palmer, in 1887, about Guaymas, Mexico, at Muleje and Los Angeles Bay in Lower California and on the island of San Pedro Martin in the Gulf of California. Proc. Amer. Acad. Arts 24: 36-82.

Watson. S. 1890. Contributions to American botany. 2. Descriptions of new species of plants from Norhtern Mexico, collected chiefly by Mr. Pringle in 1888 and 1889. Proc. Amer. Acad. 25: 141-163.

Zimmermann, A. 1922. Die Cucurbitaceen. Beiträge zur Anatomie, Physiologie, Morphologie, Biologie, Pathologie und Systematik. Vols. 1-2. Jena, Fischer.

Zuraxski, G., Perrot, B., Bottomley, W. \& Whitfield, P. R. 1981. The structure of the gene for the large subunit of ribulose-1, 5-bisphosphate carboxylase from spinach chloroplast DNA. Nucleic Acids Research 9 : 3251-3270. 
Apéndice I. Lista de taxones publicados en Apodanthera

1. Apodanthera anatuyana (Mart.Crov.) Pozner, Hickenia 2(40): 186. 1996. Basónimo: Melothria anatuyana Mart.Crov. Bol. Soc. Argent. Bot. 3: 98, f. 1. 1950.

2. Apodanthera argentea Cogn., Mém. Couronnes Autres Mém. Acad. Roy. Sci. Belgique 27: 42. 1877.

2a. var. angustifolia Cogn., Mém. Couronnes Autres Mém. Acad. Roy. Sci. Belgique 27: 42. 1877.

2b. var. latifolia Cogn., Pflanzenr. 66(IV. 275 I): 59. 1916.

3. Apodanthera aspera Cogn., Mem. Couronnes Autres Mem. Acad. Roy. Sci. Belgique 27: 43. 1877.

4. Apodanthera biflora Cogn., Mém. Couronnes Autres Mém. Acad. Roy. Sci. Belgique 27: 43. 1877.

5. Apodanthera bradei Mart.Crov., Notul. Syst. (Paris) 15: 44. 1954.

6. Apodanthera buraeavi Cogn. Mem. Couronnes Autres Mem. Acad. Roy. Sci. Belgique 27: 44. 1877.

7. Apodanthera catharinensis Mart.Crov., Dusenia 4: 37. 1953.

8. Apodanthera cinerea Cogn., Pflanzenr. 66(IV. 275. I): 59. 1916.

9. Apodanthera congestiflora Cogn., Pflanzenr. 66(IV. 275. I): 66. 1916.

10. Apodanthera crispa Cogn., Bull. Acad. Roy. Belgique, sér. 3, 14: 352. 1887.

11. Apodanthera cucurbitoides Lundell, Field \& Lab. 13: 23. 1945.

12. Apodanthera eriocalyx Cogn., Bot. Jahrb. Syst. 50(Beibl.111): 75. 1913.

13. Apodanthera fasciculata Cogn., Pflanzenr. 66(IV. 275. I): 67. 1916.

14. Apodanthera ferreyrana Mart.Crov., Bol. Soc. Argent. Bot. 6: 95. 1956.

15. Apodanthera galeottii Cogn. Mem. Couronnes Autres Mem. Acad. Roy. Sci. Belgique 27: 45. 1877.

16. Apodanthera glaziovii Cogn., Pflanzenr. 66(IV. 275. I): 60. 1916.

17. Apodanthera gracilis Benth., Voy. Bot. Sulphur: 99. 1845.

18. Apodanthera hatschbachii C. Jeffrey, Kew Bull. 47: 521. 1992.

19. Apodanthera herrerae Harms, Notizbl. Bot. Gart. Berlin-Dahlem 11: 770. 1933.

20. Apodanthera hindii C. Jeffrey, Kew Bull. 47: 519. 1992.

21. Apodanthera hirtella Cogn., Pflanzenr. 66 (IV. 275. I): 61.1916.

22. Apodanthera laciniosa (Schltdl.) Cogn., Mém. Couronnes Autres Mém. Acad. Roy. Sci.

Belgique 27: 39. 1877. Basónimo: Anguria laciniosa Schltdl., Linnaea 24: 755. 1851.

23. Apodanthera lasiocalyx Cogn., Pflanzenr. 66(IV. 275. I): 58. 1916.

24. Apodanthera latipetala Mart.Crov., Bol. Soc. Argent. Bot. 6: 96. 1956.

25. Apodanthera linearis (Cogn.) Mart.Crov., Notul. Syst. (Paris) 15: 46. 1954. Basónimo: Wilbrandia linearis Cogn., FI. Bras. 6(4): 34. 1878. 
26. Apodanthera longipedicellata (Cogn.) H. Schaef. \& S.S. Renner, Taxon 60(1): 133.2011.

Basónimo: Guraniopsis longipedicellata Cogn., Bot. Jahrb. Syst. 42: 173. 1908.

27. Apodanthera mandonii Cogn., Mém. Couronnes Autres Mém. Acad. Roy. Sci. Belgique 27:

41. 1877.

27a. var. canescens Cogn. Mém. Couronnes Autres Mém. Acad. Roy. Sci. Belgique 27: 41. 1877.

27b. var. dissecta Cogn. Mém. Couronnes Autres Mém. Acad. Roy. Sci. Belgique 27: 41. 1877.

28. Apodanthera mathewsii Arn., J. Bot. (Hooker) 3(21): 274. 1841.

29. Apodanthera moqueguana Mart.Crov., Bol. Soc. Argent. Bot. 6: 94. 1956.

30. Apodanthera mucronata Cogn., Mém. Couronnes Autres Mém. Acad. Roy. Sci. Belgique 27: 40. 1877.

31. Apodanthera palmeri S. Wats., Proc. Amer. Acad. Arts 24: 50. 1889.

32. Apodanthera pedisecta Cogn., Mém. Couronnes Autres Mém. Acad. Roy. Sci. Belgique 27: 39. 1877.

33. Apodanthera pringlei S. Watson, Proc. Amer. Acad. Arts 25: 149. 1890.

34. Apodanthera roseana Cogn., Contr. U. S. Natl. Herb. 3(5): 317. 1895.

35. Apodanthera sagittifolia (Griseb.) Mart.Crov., Notul. Syst. (Paris) 15: 45. 1954. Basónimo: Wilbrandia sagittifolia Griseb., Abh. König. Ges. Wiss. Göttingen 19 [PI. Lorentz.]: 97. 1874

35a. var. dissecta (Cogn.) Mart.Crov., Notul. Syst. (Paris) 15: 45. 1954. Basónimo: Wilbrandia villosa Cogn. var. dissecta Cogn., Pflanzenr. 66(IV. 275. I): 74. 1916. Wilbrandia sagittifolia Griseb. var. dissecta (Cogn.) Mart.Crov., Bol. Soc. Argent. Bot. 1: 317. 1946

35b. var. villosa (Cogn.) Mart.Crov., Notul. Syst. (Paris) 15: 45. 1954. Basónimo: Wilbrandia villosa Cogn., FI. Bras. 6(4): 34. 1878. Wilbrandia safittifolia Griseb. var. villosa (Cogn.) Mart.Crov., Bol. Soc. Argent. Bot. 4: 316. 1946.

36. Apodanthera scaberrima Brandegee, Univ. Calif. Publ. Bot. 10(2): 188.1922.

37. Apodanthera scabra Cogn., Bull. Acad. Roy. Belgique, sér. 2, 49: 192. 1880.

38. Apodanthera smilacifolia Cogn., Mém. Couronnes Autres Mém. Acad. Roy. Sci. Belgique 27: 42.1877.

38a. var. angustifolia Cogn., Pflanzenr. 66(IV. 275. I): 60. 1916.

39. Apodanthera succulenta C. Jeffrey, Kew Bull. 47(3): 521. 1992.

40. Apodanthera trifoliata Cogn., Pflanzenr. 66(IV. 275. I): 66. 1916.

41. Apodanthera tumbeziana Harms, Notizbl. Bot. Gart. Berlin-Dahlem 11: 770. 1933.

42. Apodanthera ulei (Cogn.) Mart.Crov., Bol. Soc. Argent. Bot. 6: 97. 1956. Basónimo: Melothria ulei Cogn., Pflanzenr. 66 (IV. 275. I): 82. 1916.

43. Apodanthera undulata A. Gray, Smithson. Contr. Knowl. 5, Art. 6 [PI. Wright. 2]: 60. 1853. 
43a. var. australis McVaugh. FI. Novo-Galiciana 3: 493, f. 97. 2001.

44. Apodanthera villosa C. Jeffrey, Kew Bull. 47: 523, f. 4. 1992.

45. Apodanthera weberbaueri Harms, Notizbl. Bot. Gart. Berlin-Dahlem 11: 771. 1933. 
Apéndice II. Índice de colecciones estudiadas

\author{
1. Apodanthera anatuyana \\ 2. Apodanthera biflora \\ 3. Apodanthera cinerea \\ 4. Apodanthera eriocalyx \\ 5. Apodanthera ferreyrana \\ 6. Apodanthera hirtella \\ 7. Apodanthera laciniosa \\ 8. Apodanthera mandonii \\ 9. Apodanthera mathewsii \\ 10. Apodanthera tumbeziana \\ 11. Apodanthera ulei \\ 12. Apodanthera weberbauerii \\ 13. Ceratosanthes palamta \\ 14. Cucurbitella asperata \\ 15. Cucurbitopsis aspera \\ 16. Cucurbitopsis palmeri
}

\author{
17. Cucurbitopsis undulata \\ 18. Doyerea emetocathartica \\ 19. Doyerea trifoliata \\ 20. Gurania spinulosa \\ 21. Halosicyos ragonesei \\ 22. Melothria pendula \\ 23. Melothria warmingii \\ 24. Melothrianthus argenteus \\ 25. Melothrianthus glaziovii \\ 26. Melothrianthus sagittifolius \\ 27. Melothrianthus smilacifolius \\ 28. Pseudoapodanthera fasciculata \\ 29. Pseudoapodanthera hindii \\ 30. Pseudoapodanthera pedisecta \\ 31. Pseudoapodanthera villosa \\ 32. Wilbrandia ebracteata var. bracteata
}

Abisaí 2514 (15); Ameghino s.n. (BA-28815) (26), s.n. (BA-68476) (26); Amorim 3845 (19), 3880 (31), 3889 (25); Andrade 93 (25); Andrieux 175 (15), 368 (15); Arbo 5497 (19); Arenas 3249 (1); Arsène 8301 (15).

Barclay 14A886 (17); Barkley 1178 (17); Bastián 228 (6); Bautista 3132 (31); Beck 18318 (20); Belgrano 400 (32), 647 (22); Beltrán 122 (4); Bertoni 2100 (26); Biganzoli 345 (22); Bigelow s.n. (17); Biurrun 5490 (26); Blumer 3257 (17); Brade 9210 (24); Brade 13507 (30); Brandegee s.n. (16); Brunel 20 (8), 84 (8); Buchtien 225 (9); Burkart 6672 (26), 6674 (26), 12587 (26), 12588 (14), 16027 (13), 20121 (1), s.n. (26); Butterwick 2806ª (17).

Cabrera 1 (26), 2060 (26), 27227 (14); Campos 2336 (12); Cantino 509 (21); Carrington 2253 (18); Carvalho 2797 (19), 6914 (27); Castellanos 705 (26), s.n. (BA-25/1003) (26), s.n. (BA25/1432) (26), s.n. (BA-25/1746) (26), s.n. (BA-28816, LIL-36234) (26), s.n. (LIL-36232) (26); Cerrate 1120 (4); Charpin 20452 (23); Chiang 7730 (17); Coêlho de Moraes 2084a (25), 2208 (25); Conzatti 17M443 (15); Correll 18448 (17); Cory 52919 (17), 52987 (17), 53036 (17); Costa 86 (25); Coues 155 (17); Cruden 1044 (16); Cuadros 2121 (18); Cutler 12054 (15), 12081 (15).

Daguerre s.n. (26); D’Angelo 809 (26); Deginani 1150 (22); Dieterle 3427 (15), 3550 (15), 4221 (15); Dusén 6531 (11), 9326 (7).

Ecker 7379 (17); Eggert s.n. (17); Engelmann s.n. (17); Ezcurra 523 (26).

Fabris 6311 (6); Ferreyra 2666 (8), 5888 (2), 7049 (4), 7089 (12), 7107 (9), 7384 (9), 8628 (5), 8957 (4), 9065 (2), 9107 (2); Ferris 2462 (17), 2714 (17); Fiebrig 2451 (6); Fisher 44176 (15); Fortuna s.n. (26); Fuentes 2261 (1). 
Galeotti 1886 (15); Gallinal PE-5513 (26); Gaudichaud 980 (7); Gay 1815 (8), 1967 (8); Gentry 2357 (16), 20197 (15); Gibert 411 (26); Giulietti 1391 (29), 3262 (31); Glaziou 1614 (24), 4817 (24), 8714 (24), 9466 (24), 14850 (24), 14850 b (24), 17009 (27), 18253 (24), 20328 (25); González s.n. (15); Goodspeed 30241 (4); Gould 4380 (17); Griffiths 1591 (17), 1627 (17); Grimes 2597 (17); Grosourdy 13 (18); Grupo Pedra do Cavalo 372 (25); Guedes 10491 (25).

Handro 1025 (24); Harley 16477 (25), 18955 (31), 21029 (29), 21534 (19), 22753 (31), 22833 (31), 25196 (30), 25895 (29), 26688 (29), 27129 (25), 54296 (19); Harris C16364 (17), C16458 (17), C16489 (17), 25724 (15); Hatschbach 344 (11), 4273 (11), 9289 (11), 15498 (7), 28269 (7), 41562 (11), 42344 (31), 42691 (7), 44978 (11), 48074 (30), 49483 (27), 52706 (30), 65111 (25), 65978 (25); Haught 141 (2), 141a (2) s.n., F.P.I. 88329 (2); Hauman s.n. (BA-28812) (26), s.n. (BA-28813) (26), s.n. (SI-25359) (26); Herrera 3038 (8); Hicken 550 (26), 558 (26), s.n. (SI25358) (26), s.n. (SI-25312) (26); Hieronymus s.n. (26); Higgins 8710 (17), 17658 (17); Hinckley 548 (17), s.n. (17); Hitchcock 6781 (17); Homberg 204 (17); Huerta 105 (15); Hunziker 2765 (26), 4379 (26), 7234 (26), 11539 (26); Hutchison 1152 (9).

Ibarrola 2761 (26); Iltis 602 (4); Irwin 32643 (31).

Jardim 4003 (31); Johnston 286 (18), 1243 (17), 8136 (17), 11523 (17).

Kearney 14852 (17); Kelly 612 (15), 704 (15); Kennedy 7035 (17); Kenoyer 1921 (15); Kiesling 6649 (26), 8924 (6); Koczicki 230 (11); Krapovickas 2959 (26), 5931 (14), 38025 (25), 38213 (7), 43719 (7); Kuhnemann 299 (26), 385 (26).

Lanfranchi 1722 (26); Lee 46173 (17); Lefebre s.n. (26); Leiva G. 1725 (12); Lemmon 180 (17), 2709 (17); Leuenberger 4508 (26); Lewis 40724 (8); Liebmann 56 (15); Lillo 7886 (26); Lima 367 (7); Linares 7537 (18); López 486 (12); Lorentz 173 (26); Lundell 5296 (15).

Macbride 337 (4), 2891 (4), 3146 (9); Mandon 1045 (8); Manning 531280 (15); Maranta 311 (1); Marin 126 (8), 1881 (8); Martínez Crovetto 2393 (26); Mathews 932 (9); Mattos 13087 (7); McDougal 791 (17); Mearns 846 (17), 890 (17), 1571 (17), 1853 (17), 1882 (17); Melo 1785 (27); Meninci 69 (26); Mexia 4112 (9); Meyer 17483 (6); Miccio Peralta 473 (26); Miranda 1246 (25); Mogilner 24 (26); Moore 3099 (15), 4190 (15); Mori 9971 (25); Mostacero L. 1062 (12); Mulford 1057 (17). Múlgura 1424 (23).

Nee 36663 (9), 36706 (6), 45993 (20), 53584 (9); Niederlein 1309 (7); Noblick 4218 (25); Noyes 228 (17); Núñez 6441 (8), 7312 (8), 7497 (8).

Ochoa 471 (9); Osten 17030 (26).

Palmer 281 (15), 282 (16), 315 (15), 324 (15), 1444 (16), 34031 (17), s.n. (17); Parks 30818 (17); Parodi s.n. (26); Partridge s.n. (BA-59885) (26), s.n. (BA-60315) (26); Pastore s.n. (26); Pedersen 9963 (26), 13202 (26), s.n. (26); Peebles 5301 (17); Pereyra s.n. (26); Pérez Moreau 
s.n. (26); Pickel 3240 (25); Pire 1187 (26); Pozner 253 (26), 254 (26), 257 (26); Pringle 49 (16), 3501 (15), s.n. (17); Proyecto Ventania 679 (26); Purpus 3550 (15), 3551 (15), 4530 (17).

Queiroz 5920 (25).

Ragonese 7140 (1); Rambo 31246 (7), 34924 (7), 37163 (7), 40202 (7); Reed 242 (17); Reina 97-772 (17); Reitz 3273 (7), 5019 (11), 5859 (11), 8385 (11), 8606 (11), 11711 (7); Rodríguez 2149 (9); Rose 253 (15), 9655 (15), 9838 (15), 9895 (15), 19954 (19); Rosengurtt 5869 (26); Ruiz \& Pavón s.n. (9).

Sagástegui 9218 (12), 12973 (12), 15387 (12); Saint-Hilaire B1 851 (27), B1 1581 (30); Sánchez Vega 863 (12), 3995 (12); Sanders 4060 (17); Saravia Toledo 11514 (1); Sauer 1019 (15), 1053 (15); Sawada 113 (9); Sayago 225 (26); Schaffner 387 [766] (15); Schott III.3 (17); Schulz 7172 (26), s.n. (26); Sehnem 8149 (7); Sello 3586 (26), 4307 (7), s.n. (BR-649 297) (26); Shreve 9406 (17); Silva 256 (11); Smith 8953 (7), 9140 (7), 10224 (7), 10981 (7), 13643 (7); Solbrig 4469 (15); Soukup 6325 (8); Souza 5154 (30); Sparre 5291 (26); Spegazzini s.n. (26); Spencer 423 (17); Spruce 6462 (2); Stafford 979 (8), 1173 (8), 21 (17); Stehmann 300 (7); Steiger 406 (17), 499 (17), 604 (17), 1378 (17), 1395 (17); Stevens 22083 (8), 22361 (18); Stienstra 32 (11), s.n.(SI-25305) (11); Svenson 11296 (2).

Tamayo 2615 (13); Thurber s.n. (17); Tolaba 1349 (1); Torres 3600 (17); Toumey 174 (17), s.n (17).

Ule 1141 (11), 1472 (7), 6759 (3), 7005 (28), 7269 b (19), 7270 (25), 7570 (19).

Vargas 216 (8), 7642 (8), 9128 (8), 9699 (9), 9775 (8); Vaughn 637 (16); Vignati 183 (26).

Ward 81-330 (17); Warnock 4400 (17), 7852 (17), 10108 (17), s.n. (17); Wasum 849 (7); Waterfall 4898 (17); Weberbauer 5343 (4), 5944 (2), 7263 (8), $7273^{a}$ (8), 7485 (12), 7691 (10), $7691^{a}$ (10), 7897 (4); Weigend 2000/165 (8); White 919 (17), 2155 (17), 3781 (17), 3827 (17); Whitehouse s.n. (17); Wieder 205 (15); Wied-Nauwied s.n. (30); Wiggins 77 (16); Wilcox s.n. (17); Wislizenus 116 (17); Wolf 2539 (17), 11390 (17); Wood 15980 (6); Wooton 148 (17), s.n. (17); Worthington 12022 (17), 14701 (17); Woytkowski 196 (8); Wright 1382 (17); Wynd 767 (17).

Yellow 353-69.03047 (26); York 48115 (17). 
Apéndice III. Nuevas combinaciones propuestas

Cucurbitopsis (Cogn.) Mart.Crov. ex Belgrano = Apodanthera Arn. sect. Cucurbitopsis Cogn. Cucurbitopsis aspera (Cogn.) Mart.Crov. ex Belgrano = Apodanthera aspera Cogn.

Cucurbitopsis palmeri (S. Watson) Mart.Crov. ex Belgrano = Apodanthera palmeri S. Watson Cucurbitopsis undulata (A. Gray) Mart.Crov. ex Belgrano = Apodanthera undulata A. Gray Doyerea trifoliata (Cogn.) Belgrano = Apodanthera trifoliata Cogn.

Melothrianthus argenteus (Cogn.) Belgrano = Apodanthera argentea Cogn.

Melothrianthus glaziovii (Cogn.) Belgrano = Apodanthera glaziovii Cogn.

Melothrianthus sagittifolius (Griseb.) Belgrano = Apodanthera sagittifolia (Griseb.) Mart.Crov. Pseudoapodanthera (Cogn.) Belgrano = Apodanthera Arn. sect. Pseudoapodanthera Cogn.

Pseudoapodanthera fasciculata (Cogn.) Belgrano = Apodanthera fasciculata Cogn.

Pseudoapodanthera hindii (C. Jeffrey) Belgrano = Apodanthera hindii C. Jeffrey

Pseudoapodanthera pedisecta (Cogn.) Belgrano = Apodanthera pedisecta Cogn.

Pseudoapodanthera villosa (C. Jeffrey) Belgrano $=$ Apodanthera villosa C. Jeffrey 
Apéndice IV. Nuevas sinonimias propuestas

Apodanthera congestiflora Cogn. $=$ Doyerea trifoliata $($ Cogn.) Belgrano Apodanthera crispa Cogn. = Cucurbitopsis aspera (Cogn.) Mart.Crov. ex Belgrano Apodanthera cucurbitoides Lundell = Cucurbitopsis aspera (Cogn.) Mart.Crov. ex Belgrano Apodanthera herrerae Harms = Apodanthera mandonii Cogn.

Apodanthera latipetala Mart.Crov. = Apodanthera mathewsii Arn.

Apodanthera linearis (Cogn.) Mart.Crov. = Melothrianthus sagittifolius (Griseb.) Belgrano Apodanthera mandonii Cogn. var. dissecta Cogn. = Apodanthera mandonii Cogn. Apodanthera mandonii Cogn. var. canescens Cogn. = Apodanthera mandonii Cogn. Apodanthera moqueguana Mart.Crov. = Apodanthera mandonii Cogn. Apodanthera mucronata Cogn. = Apodanthera mathewsii Arn. Apodanthera roseana Cogn. = Cucurbitopsis palmeri (S. Watson) Mart.Crov. ex Belgrano Apodanthera sagittifolia (Cogn.) Mart.Crov. var. dissecta (Cogn.) Mart.Crov. = Wilbrandia villosa Cogn. var. dissecta Cogn. = Melothrianthus sagittifolius (Cogn.) Belgrano Apodanthera sagittifolia (Griseb.) Mart.Crov. var. villosa (Cogn.) Mart.Crov. $=$ Wilbrandia villosa Cogn. $=$ Melothrianthus sagittifolius (Griseb.) Belgrano Apodanthera succulenta C. Jeffrey = Pseudoapodanthera villosa (C. Jeffrey) Belgrano Apodanthera undulata A. Gray var. australis McVaugh = Cucurbitopsis aspera (Cogn.) Mart.Crov. ex Belgrano
Dr. Fernando O. Zuloaga
Dr. Raúl E. Pozner
Lic. Manuel J. Belgrano
Director
Director
Tesista

La Plata, noviembre de 2012 